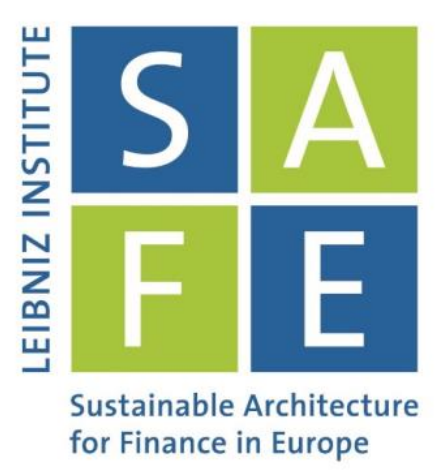

Ignazio Angeloni | Johannes Kasinger | Chantawit Tantasith

\title{
The Geography of Banks in the United States (1990-2020)
}

SAFE Working Paper No. 321

\section{Leibniz Institute for Financial Research SAFE}

\section{Sustainable Architecture for Finance in Europe}

info@safe-frankfurt.de | www.safe-frankfurt.de 


\title{
THE GEOGRAPHY OF BANKS IN THE UNITED STATES (1990-2020) ${ }^{1}$
}

\author{
Ignazio Angeloni (Harvard Kennedy School and SAFE) ${ }^{2}$ \\ Johannes Kasinger (Goethe Universität Frankfurt and SAFE) ${ }^{3}$ \\ Chantawit Tantasith (University of Oxford) ${ }^{4}$
}

\begin{abstract}
We present new statistical indicators of the structure and performance of US banks from 1990 to today, geographically disaggregated at the level of individual counties. The constructed data set (20 indicators for some 3150 counties over 31 years, for a total of about 2 million data points) conveys a detailed picture of how the geography of US banking has evolved in the last three decades. We consider the data as a stepping stone to understand the role banks and banking policies may have played in mitigating, or exacerbating, the rise of poverty and inequality in certain US regions.
\end{abstract}

\footnotetext{
${ }^{1}$ This paper has been first published as Harvard Kennedy School M-RCBG Associate Working Paper No. 177. Early work on this paper was presented on 23 April 2021 in a seminar at the Mossavar-Rahmani Center for Business and Government of the Harvard Kennedy School. The material of that seminar is available at https://ignazioangeloni.home.blog/2021/04/23/webinar-financial-factors-in-regional-poverty-and-inequality/ We are grateful to seminar participants there for useful comments. We are particularly grateful to the late Richard Brown, to Eric Breitenstein and to their colleagues at the Federal Deposit Insurance Corporation for support in the use of FDIC data. Ignazio Angeloni is grateful to the Mossavar-Rahmani Center for Business and Government at the Harvard Kennedy School for generous support and to the Leibniz Institute for Financial Research SAFE for providing a favorable work environment. Johannes Kasinger gratefully acknowledge research support from the Leibniz Institute for Financial Research SAFE.

2 iangeloni@hks.harvard.edu

3 kasinger@safe-frankfurt.de

${ }^{4}$ chantawit.tantasith@st-hughs.ox.ac.uk
} 


\section{Table of contents}

1. Introduction

2. The spatial dimension of banking

3. Literature review

4. Regulation affecting the geography of banking

5. Constructing the data

6. Quality check

7. Stylized facts

8. Conclusions and work ahead

\section{Annexes:}

Annex 1: Summary statistics (tables)

Annex 2: Summary statistics (time charts)

Annex 3: Maps and frequency distributions (selected dates)

Annex 4: Example of potential disaggregation bias

\section{Online Appendix ${ }^{5}$ :}

Annex 5: Maps and frequency distributions (dynamic charts) Annex 6: Synoptic table

\footnotetext{
${ }^{5}$ The Online appendix can be accessed here.
} 


\section{Introduction}

In this paper we present new statistical indicators of the structure, behavior and performance of the US banking sector from 1990 to today, disaggregated at the level of individual counties. Although the scope of this paper is essentially statistical, we started working with a question in mind: Has the banking sector, and the banking policies enacted during that period, mitigated or exacerbated the rise of poverty and inequality in certain regions of the United States? We regard the data we present here as a stepping stone to answer that question in future research, by us or by others.

Economic inequality has increased in many industrialized countries in recent decades, but in few places is the evidence as stark as in the US. Differences in living standards started rising in the 1980s, but the trend has accelerated after the Great Financial Crisis, and early evidence suggests that the Covid crisis may have caused further divergence. One well documented feature of the recent rise of inequality in the US is that it is "interregional" at least as much as it is "interpersonal", meaning that entire geographical areas, not only the individuals within them, diverge from others in several respects - income and wealth levels, productivity, job opportunities as well as other measures of quality of life such as health, life expectancy, crime and drug abuse. While high-performance geographical clusters strive and increasingly attract highly skilled individuals and capital, other areas steadily regress (for a description through the lens of the job market, see Moretti, 2012). The divergence between highperformance clusters and "left-behind places" (Hendrickson et al, 2018) has produced, among other consequences, political polarization and instability (Rodriguez-Pose, 2018). These considerations triggered a discussion about place-based policies in the US ${ }^{6}$ and, together with the richness of the data we describe below, suggest that the US may be an ideal subject for research on these topics.

One aspect not sufficiently analyzed in this context is the role of finance and banking. ${ }^{7}$ This is surprising for two reasons. First, a long stream of literature on finance and development has uncovered multiple causal links between the structure, development and functioning of the financial sector and economic performance and growth (see for example Rajan and Zingales 1998). Second, much research has identified a specific role of banks (as opposed to securities markets) in facilitating the process of investment and growth, especially in areas where small and medium-sized enterprises prevail (Petersen and Rajan 1995). The recent decades have witnessed a decline of the share of small and community banks in the US (Powell 2016), which could be a factor to the economic and social decline of certain regions, where small businesses are predominant. Concerns of this nature are behind the adoption of policies to support community banking, most notably the Community Reinvestment Act, first enacted in the 1970s but progressively strengthened, especially after the mid-1990s. Phenomena

\footnotetext{
${ }^{6}$ Austin, Glaeser and Summers (2014) provided a thorough documentation of spatial divergence in the United States. They also review the pros and cons of adopting place-based policies, concluding that the balance of arguments favours undertaking such policies on both equity and efficiency grounds. They then present an overview of existing and possible further policies, including tax incentives, public investment and subsidies and regulatory relief.

${ }^{7}$ Hendrickson (2018) refer to credit policies and provides some references. Austin, Glaeser and Summers (2018) do not mention credit policies specifically, but some of the policies they mention, such as for example, regulatory relief, could be applied in the areas of banking and credit as well.
} 
of this kind, and the related policy concerns, are not unique to the United States, but have also been observed in European countries such as Germany and Italy.

We focus specifically on banks, without excluding a role of market finance, for two reasons. First, impoverished areas, the main focus of the spatial inequality literature, are unlikely to have a significant access to financial markets. By contrast, their inhabitants are likely to have at least some contact with the banking sector, in one of its functions - as receiver of deposits, provider of payment services, manager of saving, supplier of various types of credit. Second, there is a rich and hitherto largely underexploited data source on the territorial presence and activities of US banks, maintained by the Federal Deposit and Insurance Corporation (FDIC). This data can be used to derive indicators of banking structure, conduct and performance disaggregated at the level of US counties, a geographical detail which not only has not been explored so far but matches the one normally used to analyze spatial inequality in the US.

The data we present, though imperfect in many ways as we shall explain ${ }^{8}$, provide a rich, fascinating, and we believe overall convincing picture of how the geography of US banks has developed over the last three decades, and of how it looks like now. To summarize the key developments, we identify 13 stylized facts based on a descriptive county-level analysis of the statistical indicators over the period we study:

1. The banks' geographical reach has increased over time (the average number of counties a single bank operates in has increased steadily).

2. The number of banks operating in each county varies strongly across regions.

3. The market share of the 5 nationwide largest banks strongly increased in most counties, with the highest shares at the East and West coast.

4. The market share of community banks shows a strong regional connotation, with many counties having either no community banks at all, or only community banks.

5. Bank assets and deposits per capita increased over time on average, with a large dispersion across counties.

6. Bank assets and deposits-to-GDP ratios are highest in the Heartland ${ }^{9}$, and decline over time on average.

7. The composition of bank lending is shifting away from agricultural and small business loans and towards household lending, mainly for real estate.

8. Bank business models in the "heartland" are characterized by a relatively large share of agricultural and small business loans and a lower levels of real estate loans.

9. Non-interest income-to-asset ratios are highest in the West with initially large, but gradually disappearing, differences between neighboring counties across state borders.

10. Dispersion in leverage is large before the GFC but converges towards higher levels in 2010s.

11. Cost efficiency ratios within counties show no clear regional pattern and are rather volatile over time.

\footnotetext{
${ }^{8}$ Their construction involved a number of assumptions and approximations, some of which are strong but necessary given the present state of available statistics.

${ }^{9}$ We refer to the "Midwest ridge", as the central region of the United States cutting North to South from the Dakotas to Texas. In addition, following a denomination used by Austin et al (2018) in a similar context, we refer to the "Heartland" as that area plus the region along the Mississippi river.
} 
12. Net interest margins declined over time in most counties, but remained relatively stable in the Heartland.

13. The GFC left a deep and persistent mark on banking performance measures.

The paper is organized as follows. After this introduction, we discuss in section 2 the conceptual and statistical complexities inherent in deriving (indeed, in defining) banking indicators that have a spatial dimension. Section 3 reviews the literature on the role of finance and banks in influencing real economic performance. Although we do not analyze such role directly in this paper, the review of the literature helps clarify what indicators are needed for that purpose. In section 4 we recap the main regulatory changes enacted in the US which matter for our questions: the Community Reinvestment Act (CRA) of 1974, with subsequent modifications, the Home Mortgage Disclosure Act (HMDA) of 1975 , which attempted to use transparency of information to address the credit shortage affecting certain disadvantaged geographical areas, and the Riegle-Neal Interstate Banking and Branching Efficiency Act of 1994, which liberalized the opening of branches across state borders. Section 5 describes the methodology we used to construct the indicators, based on elementary statistics published by the FDIC. In section 6 we perform a pilot quality check, based on home mortgage credit, to verify the accuracy of our results. In section 7 we present stylized facts, based on a set of summary statistics and "dynamic charts", which visually portray how the "banking map" of the nation has evolved over our time period. Section 8 contains conclusions and future work plans. An annex contains tables with summary statistics.

Our plan is to put these data in the public domain, after collecting some more feedback and doing other quality checks. We will be happy if our work ends-up stimulating research. Even happier if our emphasis on the spatial dimension of banking will contribute to shift the focus of banking analyses, so often concentrated on what matters for the banks themselves, towards what benefits the people and the communities they serve.

\section{The spatial dimension of banking}

Our approach hinges on the notion that there is a "spatial dimension" to banking: in other words, that banks have an influence on, and are influenced by, the conditions of the geographical area(s) where they operate. By "area" we do not mean literally the surface of land, but the complex of human and material resources located in that area - people, enterprises, human and material capital, private and public infrastructures, etc. While these categories can conceptually extend to comprise things like social capital, enviromental characteristics, quality of life, etc., in practice we will refer in this paper mainly to the economic characteristics of the areas in question. We are interested in finding out how banks influence the economy of the geographical areas in which they operate, and are influenced by that economy. Or more precisely, since this is eminently a statistical paper, on how to construct indicators that can allow to detect and to measure those influences.

While a focus on the effects of banks on local economic conditions may seem natural, even obvious, in practice it is not. In all countries we are aware of, banking statistics are not mainly constructed with that focus in mind, but rather refer to banks regardless of where they operate. Introducing the geographical dimension requires indicators which possess specific characteristics. 
It is not always easy, or even possible, to construct such indicators. A trivial and unrealistic case is one in which there is only one bank in each area, say, a region within a country, and that bank operates only in that region ("one-to-one" case). In this case there is a neat correspondence between each bank and a given area, and the chain of effects running between that bank and the area can be defined unambiguously. Also easy to handle is the case where an area is served by several banks, but each bank operates only in that area ("many-to-one" case). There is, in that case, a banking "system" serving that specific geographical unit.

Problems arise when (some) banks serve several areas ("multi-area" case). The more the geographical units of interest are small, for example administrative entities like counties or metropolitan areas, the more likely "multi-area" banks are. To fix ideas, suppose a fictional country comprising two regions, $A$ and $B$, served by three banks: Bank 1 operates only in $A$ (in the sense that it conducts business only with subjects residing in A); Bank 2 operates only in B, while Bank 3 operates in both A and B. The construction of indicators expressing the conditions of the banking "system" serving region $A$ is complicated by the fact that those conditions are partly determined by the activity that Bank 3 performs in B. In this case there is no one-to-one correspondence between banks and geographical units of interest. To be more concrete, suppose one wants to measure the links between the credit supply conditions in A and the leverage of the banks operating in that same area. It will normally not be possible, even conceptually, to construct a leverage indicator for Bank 3 which refers only to the exposures that Bank 3 holds in A. One way out is to construct a leverage indicator for banks operating in $A$ as a weighted leverage using the respective market shares in A. By and large, this is the approach we take. But that indicator will depend also on the influences between region $B$ and Bank 3 , which in turn are affected also by the characteristics of Bank 2, which has no business in $A$.

For certain types of indicators, a geograplical attribution is easier than for others. Hence it helps being more specific on what indicators we are talking about. In order to identify a set of indicators of banking conditions relevant to measure geographical influences, we refer to the relevant academic literature - see a review in a later section. In particular, the literature on the structure, performance and efficiency of the banking industry (Molyneaux and Forbes 1994, Lloyd-Williams, Molyneux \& Thornton 1994, Berger 1995, Berger, Demirgüç-Kunt, Levine \& Haubrich 2004, Choi and Weiss 2005, including the references therein) concentrates on the linkages between the structure of the banking market (monopolistic, oligopolistic or more or less competitive), banking conduct (business models, product and sector specialization) and performance (profitability, solvency, risk appetite, etc.), in the attempt to find relationships between those features and the quality and cost of banking services.

Following that literature, one can define three classes of indicators:

1. Structure. Structural measures refer inter alia to measures of competition such as the number of banks operating in an area, their degree of concentration, the incidence of multi-area banks, measures of the bank intensity such as percapita asset or asstt/GDP ratios, etc.

2. Business model. These measures express the way of conducting banking business, such as for example the type of services offered, the client or sectoral composition, the specialization in offering certain products or services, the type of funding, etc.

3. Performance. These indicators measure how "successful" the banking business is, from several angles; its solvency and soundness (capital ratios, leverage), profitability (return on capital or assets, interest margins), riskiness (cost of risk, asset quality, etc.) 
These three categories not only look at the nexus between banks and the local economy from different angles, but differ also in how easily the corresponding indicators can be constructed. The structural indicators are the easiest from this point of view. Measures like concentration, market shares, and the like, are naturally referred to geographical areas because the latter provide a definition of a relevant market. More difficult is the situation for business model and performance indicators, which naturally refer to banks, not to areas or markets. If a "one-to-one" or "many-to-one" correspondence applies, such correspondence is easily established. Not so when when there is a significant share of banks operating in several areas.

In specific cases, business model or performance indicators can connect with geographical characteristics. For example, a bank's sectoral specialization (such as the share of agricultural loans) is linked to the economy where it operates. Measures of asset quality like non-performing loan ratios depend on the local economic performance and in principle could be broken down according to the geographical destination of the loan. But these are exceptions, and even here the geographical nexus is usually not exact. Further obstacles reside in the way banking statistics are collected and published. For example, whereas detailed data on the sectoral composition of loans for each bank exist for each bank operating in the US, that sectoral breakdown is available at the bank level only and not by areas of destination. For all those reasons, the construction of area-specific banking indicators must make recourse to certain assumptions and approximations.

The extent of those approximations changes over time. As the evidence in the subsequent sections shows, the geography of banking markets in the US has changed significantly over the last 30 years, partly due to regulatory changes and exceptional events such as financial crises. Among the regulatory drivers of change, summarized in a later section, one was the liberalization of interstate branching in the mid-1990s. In the initial part of the period considered, a very large part of the US banking marked was consituted by local or semi-local banks. More than two decades after those regulatory changes, this is - surprisingly - still largely the case, but less than previously and decreasingly so. This makes constructing our indicators more complex and increases the scope for assumptions and approximations. Section 5, in which our methodology is explained, discusses in detail what assumptions and approximation we made.

\section{Literature review}

The focus of interest in this paper lies at the intersection of two strands of literature. One regards the drivers of economic growth and inequality, especially in a spatial dimension. The second concerns the role of finance, and banks particularly, among those drivers. In this section we briefly review the second line of research, useful to identify the indicators which can best express that role. We first review the broader contributions on the link finance-growth-inequality, then focus on the role of banks.

Dating back to Bagehot (1873), a vast body of empirical and theoretical evidence demonstrates the importance of the financial system for real sector economic development (Levine (2005) and Beck \& Levine (2018). Most empirical studies exploit cross-country variations and find a positive relationship between measures of financial development and economic growth. To only name a few examples: King \& Levine (1993) analyze data for 80 countries for the period 1960-1989 and lend support to Schumpeter's traditional argument (1911) that financial intermediaries foster technological progress 
and economic development; Rajan \& Zingales (1998) show that sectors who strongly rely on external finance grow comparably faster in countries with more developed financial markets; Beck et al. (2000) exploit an instrument variable and panel estimation approach to establish a more causal link and conclude "that financial intermediaries exert a large, positive impact on total factor productivity growth, which feeds through to overall GDP growth"; Exploiting similar approaches, Levine et al. (2000) find a strong relation between exogenous variations in financial intermediary development and economic growth. Aghion et al (2005) identifies financial development as one of the main reasons why some countries have a strictly lower growth rate than others.

Despite this compelling evidence, there is an increasing number of more recent studies that identify limits and considerable non-linearities to these positive effects with important policy implications (Beck 2013a, Beck et al. 2010a). Arcand et al. (2015) find negative marginal effects of financial depth, measured in terms of credit to the private sector, on economic growth for high levels of financial development. Cecchetti \& Carroubi (2012), Beck R. et al. (2014) and Demetriadis \& Rousseau (2016) come to a similar conclusion in their cross-country analysis. Analyzing a historical data set of financial crises in different countries, Schularick \& Taylor (2012) identify excessive credit growth as a key predictor for financial crises and consequently for economic growth. Furthermore, there are numerous studies that provide evidence for differential industry-and region-specific effects of financial development; with largest positive effects in sectors that rely comparably more on external finance, such as intangible and R\&D intensive industries (e.g. Claessens \& Laeven 2003, Guiso et al. 2004a, Guiso et al. 2004b). Relatedly, Beck et al. (2008) provide evidence that financial development disproportionally benefits small and opaque firms because of larger marginal effects of decreased external financing cost. Fisman \& Love (2007) add to this literature by demonstrating that diverging growth opportunities between industries are an even better predictor for comparably stronger effects of financial developments than financial dependence (for a review of the empirical literature, see Popov, 2018).

Overall, the empirical findings show that there is a positive effect of financial deepening on economic growth on average. However, this positive relation does not have to hold "at the margin", i.e. for a highly developed banking sector, (Zingales 2015) and is heterogenous depending on the characteristics of the financial sector and activities (Valickova et al 2014, Popov 2018). These conditionalities are particularly important for our question as banking is typically more local compared to securities markets (Berger \& Roman 2018) and varies considerably between different regions within a country, which are themselves very heterogenous. The literature has identified several characteristics of financial intermediation/banking that are central for the differential and contextspecific real effects of financial intermediation. The characteristics can be broadly grouped into three categories (see section 2): i) structural indicators of the banking market, including its size and competition; ii) the type of business models of banks; as well as iii) the quality and performance of banks (stability, effectiveness-efficiency, profitability, etc.).

A wide class of banking indicators has been singled out and analyzed in the literature to measure the organization of the banking market, including measures such as the average bank size, degree of market competition, the type of services offered and multiple variables expressing the performance of the banking firms. Perhaps the most often used metric in this category is the size of the intermediary, usually proxied by the dimension of its balance sheet. Small banks are usually deemed to be more flexible, particularly in dealing with soft information on borrowers, and thus have a 
tendency to lend to small businesses and entertain close ties with them - so-called relationshipbanking. For example, Scott (2004) finds that community banks generate soft-information of higher quality. By contrast, larger banks with a more complex organizational structure usually rely more on "hard", quantifiable information and as a result tend to lend to larger corporations that have a proven track record of solid financial figures - so-called transaction banking (e.g. Boot \& Thakor 2002, Cole et al. 2004, Berger \& Udell 2006, Berger \& Roman 2018). Following this line of argument, community banks may be particularly important to small-medium enterprises (SMEs) because of the possibility to overcome information asymmetries between borrower and lender even if their business models are rather opaque (Berger \& Udell 2002). Yet, the empirical evidence on the relative merits of relationship lending vs. transaction banking are not conclusive (Duqi et al. 2018). There is no clear evidence that SMEs are more likely to borrow from smaller and local banks than from larger institutions (Beck 2013b) or that SMEs have a stronger relationship to community banks as compared to megabanks (Berger et al. 2014). The conventional wisdom is further challenged by deregulation, new technologies and better data availability, which decrease the comparative advantages of smaller banks (Berger \& Roman 2018). Nevertheless, there are several recent studies that demonstrate that high local presence of small banks is still connected to better performances of small businesses (e.g. Berger et al. 2015, Berger et al. 2017). LaPorta et al. (2002) examine the effect of bank ownership on real economic output and find that a higher level of public ownership is associated with lower total productivity growth in the future. Concentrating on community banks, Feldman \& Langford (2019) show that a high community bank market share within a county is associated with a lower likelihood for recession conditions.

Another dimension that is crucial for the real effects of financial intermediation is the degree of market competition. Theoretically, the effect of increased bank competition on economic growth and supply of credit is ambiguous and depends on the extent of information asymmetries. Competition is expected to have a negative effect for small and opaque firms, while for bigger and established firms effects are likely to be positive (e.g. Klein 1971, Petersen \& Rajan 1995, Marquez 2002). Zarutskie (2006) provides empirical evidence for this conjecture. However, there might also be another side of the coin. Competition tends to increase innovation in the banking sector, which in turn decrease overall borrowing cost. Black \& Strahan (2002) and Rice \& Strahan (2010) provide empirical support for this channel, suggesting that these benefits outweigh potential negative effects for small businesses. In a cross-country study, Claessens \& Laeven (2005) show that growth rates of financially dependent industrial sectors are higher in countries with more competitive banking systems, leading to the conclusion that the "degree of competition is an important aspect of financial sector functioning". By exploiting intra- and interstate banking deregulation, Chava et. al (2013) find that lower local market power of banks is positively associated with economic growth. Jayakumar et al (2018) draw a similar conclusion using a panel vector error-correction model.

Several studies suggested that the marginal effect of banking on economic growth depends in large part on the type of financial activities, i.e. the bank business models. In a cross-country analysis of 77 countries over the period between 1980-2007, Beck et al. (2014) find that intermediation activities, proxied by private credit to GDP, have positive long-run effect on real sector outcomes, while they find no significant effects for non-intermediation activities. In addition, bank business models that rely heavily on noninterest income are usually very risky, which may have detrimental long-run economic effects that outweigh potential diversification benefits (Demirgüc-Kunt \& Huizinga 2010). Furthermore, the traditional theoretical argument why finance is an important driver for economic 
growth depends on the enterprise credit channel (Schumpeter 2011). The predicted effects of credits to households (largely, mortgage credits) - the largest contributor to credit growth in recent years are ambiguous (Beck 2013a). In contrast to enterprise credit, household credit is empirically not positively associated with economic growth (Beck et al 2012). Other studies (e.g. Sassi \& Gasmi 2014, Bezemer et al. 2016, Benczúr et al. 2019) even estimate negative effects of household credit expansion on economic growth, providing further evidence on the relevance of considering the type of credit.

In addition, there is a growing body of literature on finance and economics that links the effectiveness of financial intermediation to the stability of the banking sector. Several studies find a positive relation between financial deepening and the likelihood of a financial crisis, particularly if credit growth happens rapidly or expends over a long period of time (e.g. Kaminsky \& Reinhart 1999, Jordà et al 2011, Schularick \& Taylor 2012, Laeven \& Valencia 2018). Financial instability has a negative effect on economic growth in the short run. Accordingly, Loayza \& Rancière (2006) explain the "mostly negative" short-run relation between financial intermediation and output growth by financial fragility in observed countries. Complementing these findings, several cross-country studies find a positive statistical association between banking sector stability and economic growth (e.g. Jokipii \& Monnin 2013, Jayakumar et al. 2018). Moreover, banking sector instability can also have detrimental long-run implications as a distressed banking sector cannot fulfill its intermediary role as effective as possible. Dell'Ariccia et al. (2008) provide evidence that a banking sector problems lead to "independent negative real effects" that can hinder real economic activity also in the long run. A sign of a distressed banking sector are high levels of non-performing loans (NPLs) on bank balance sheets. If met by inadequate regulatory measures, high levels of NPLs may incentivize "Zombie-Lending" (i.e. lending to non-viable firms), which in turn hinders innovation and has negative effects on economic growth (Caballero et al 2006). The Zombie-Lending channel has important policy implication both for fiscal as well as monetary policy (e.g. Acharya et al. 2019, Kasinger et al. 2021, Acharya et al. forthcoming).

The likelihood of a banking crisis tends to increase with a high leverage ratio of banks. In contrast, it may increase lending costs of borrowers in the short run. Evaluating this complex tradeoff, Miles et al. (2013) conclude that the amount of bank capital in the 2000s was well below the optimal level. Barth \& Miller (2018) come to a similar conclusion. In addition, higher bank capital improves relative performance of banks in banking cries (e.g. Berger \& Bouwman 2013, Demirgüc-Kunt et al. 2013) and leads to higher bank valuations (Mehran and Thakor 2011). This is relevant as performance and efficiency of banking may have a feedback effect on real economic performance. As an example: Cole et al. (2008) find a positive relation between bank stock returns and future economic growth. Hasan et al. (2009) show that cost- and profit-efficiency measures of banking is an important driver of regional economic growth that may easily exceed the effects of quantitative credit expansion.

Complementing the literature that studies the relation between finance and growth, several studies focus on the effects of financial development on inequality. Demirgüç-Kunt \& Levine (2009) provide a critical review of this literature. They conclude that, while the theoretical predictions about the link between finance and inequality and relevant channels are ambiguous, the vast majority of empirical studies suggests that financial development reduces inequality. Many studies focus on developing countries and show that financial deepening reduces poverty (e.g. Burges \& Pande 2005, Karlan \& Zinman 2010). In a cross-country study, Beck et al (2007) provide evidence that "financial development disproportionately boosts incomes of the poorest quintile and reduces income inequality", using three different measures of inequality: the Gini-coefficient of different countries, the income share of the poorest households and number of people living with less the $\$ 1$ per day. A similar analysis by Zhang 
\& Naceur (2019) further suggests that financial access, efficiency and stability helps to reduce income inequality. Exploiting a quasi-natural experiment, Beck et al (2010b) find that intrastate branch deregulation - through increased banking competition and efficiency - disproportionately boosted income of low-income workers and thus reduced income inequality. Another channel already discussed above relates to the comparably large effect of financial development on the economic success of small firms (e.g. Rajan \& Zingales 1998, Beck et al 2005, Beck et al 2008).

\section{Regulation affecting the geography of banking}

The United States has a long history of financial regulation designed for social purposes. Until and including the landmark Fair Housing Act of 1968 (part of President Johnson's Civil Rights Act, which specifically prohibited race discrimination on housing matters including mortgage lending), however, such legislation did not have a geographical connotation. In other words, it did not influence credit flows based on location (to benefit poorer or disadvantaged areas), but only based on the borrowers' characteristics (to help poorer or disadvangaged people).

The first legislation with a geographical imprint is the Home Mortgage Disclosure Act (HMDA) of 1974, which was motivated by a desire to encourage mortgage lending in degraded urban areas and communities. HMDA attempted to attain its purpose by promoting transparency; a main section of the legislation require mortgage institutions to publish individual information on their credit assessment processes, to show if their home lending decisions support the housing needs of the areas where they are located. HMDA legislation provides, still today, the legal basis of much granular information on the geographical distribution of home mortgage lending, that we ourselves used for the quality check described in section 5 .

Important legislation from a credit geography viewpoint is the Community Reinvestment Act (CRA), passed into law by President Carter in 1977 and repeatedly modified (in fact, strengthened) until recent times. CRA covers a range of credit products, but in practice most of the regulators' attention has concentrated on residential mortgage lending, on which granular statistical information is available pursuant to the HMDA. Residential mortgage credit tends to be penalized in disadvantaged areas, even if granted to prime borrowers, by the fact that collateral values are depressed in those areas. To achieve its purpose, CRA mandates supervisory authorities of FDIC-insured institutions to include in their examinations an assessment of the extent to which the institution provides credit in the communities where they operate. For that purpose, CRA indicates a set of criteria and a scoring system to "guide" the supervisory assessment.

Though the law does not suggest, at least explicitly, that more risky loans be granted (in fact it prescribes that credit should be "safe and sound") a debate has developed, especially after the Financial Crisis, on whether CRA resulted in riskier mortgage lending. Agarwal et al. (2012)'s econometric tests find that this was indeed the case. They compare the riskiness of residential mortgage loans originated by banks which are undergoing a CRA supervisory test by their supervisory institution, with the riskiness of the loans extended by banks not subject to that test. Supervisory tests are conducted according to a fixed calendar, more frequent for large banks. The authors find that $5 \%$ more loans are granted in periods close to the tests, and that those loans defaulted $15 \%$ more often. Black (2013) argued that the increased riskiness may have been due to factors other than the effects of the legislation.

A separate question is whether CRA has been effective in its intended purpose of benefitting the local communities. Avery et al. (2003) compare the performance of census tracts (within-county 
geographical sub-units) with relative percapita income level just above or just below the CRA-eligibility threshold. They find that CRA-eligible census tracts (with income just below the threshold) are characterized by higher home ownership and lower vacancy rates, consistent with the legislation achieving its purpose. However this result does not extend to broader measures of economic performance, and is not robust to changes of the methodology used (for example, inverting the test to measure the relative performance of non-eligible tracts, rather than that of eligible ones). All in all, the authors judge their evidence as inconclusive.

In 1995, the US Congress passed the Riegle-Neal Interstate Banking and Brenching Efficiency Act, permitting banks to conduct banking operations and to open up branches across state boundaries. Though the rationale behind Riegle-Neal was separate from those underlying the other pieces of legislations that we have just mentioned, there was a link in the fact that the greater scope for geographical banking diversification which Riegle-Neal permitted could give rise, especially for large banks, to a greater disconnect between location of funding and of credit, hence possibly making banks depart from the support to local communities which CRA intended to promote. It is worth noting, in this regard, that in order to be authorized to expand across states banks were required to show compliance with CRA; this demonstrates the legislator's intention to maintain a balance between the geographical diversification of banks and their local "rooting".

Be that as it may, among the several amendments which CRA underwent over the decades a major one took place in 1995, a year after the passage of Riegle-Neal. The regulation changes making CRA rests more extensive and detailed, and more focused on lending activities as opposed to service providing. As argued Avery et al (2003), which describe them in more detail, the 1995 changes were sufficiently important to have changed the behavior of lenders, causing them to intensify their focus on compliance with the act thereby possibly increasing the extension of credit to CRA-eligible areas and modifying their risk profile.

\section{Constructing the data}

To construct our county-level banking indicators we use two statistical sources publicly available from the FDIC:

1. Call Report data (CR), including a large number of balance sheet and other data for each FDICinsured financial institution, at quarterly frequency;

2. Summary of Deposit data (SoD), the annual survey of branch office deposits for all FDIC-insured institutions (reference date is 30 June each year).

In a nutshell, as a first step we use the information on the geographical distribution of deposits of each bank from SoD, aggregated at county level using the branch location flags available in CR, to estimate the county-level breakdown of aggregate balance sheets. We then use these estimates to allocate, at county-level, a selected number of indicators of each bank from CR. The indicators we calculate have yearly frequency and are temporally located at year-end for stock (balance sheet) variables, and the whole year for the flow (income and expenditure) variables. Finally, we obtain the county-level indicators as averages of all the banks operating in that county, weighted by market shares. SoD data have already been used to infer the geographical location of small business loans by Avery et al. (2003) and Jagtiani and Lemieux (2016). We extend their method and use it to obtain a larger set of indicators. 
Based on the literature summarized in section 3, we concentrate on three classes of variables describing respectively the market structure, the business model, and the performance of the banks concerned:

\section{STRUCTURAL INDICATORS}

Number of banks

Number of counties a bank operates in

Share of the largest bank by assets (\%)

Share of community banks by assets (\%)

Share of top 5 US banks by assets (\%)

Per capita deposits (\$ Thou.)

Deposits/GDP (\%)

Per capita assets (\$ Thou.)

Assets/GDP (\%)

\section{BUSINESS MODEL INDICATORS}

Share of agricultural loans (\%)

Share of commercial/industrial loans (\%)

Share of C\&l loans below $1 \mathrm{mn}$. (\%)

Share of real estate loans (\%)

Non-interest income to asset ratio (\%)

\section{PERFORMANCE INDICATORS}

Common Equity Tier 1 ratio (\%)

Leverage ratio (\%)

Efficiency ratio $(\%)^{10}$

Pretax Return on Assets (\%)

Net Interest Margin (\%)

Non-performing assets ratio (\%)

For the first group of indicators we estimate the county breakdown of bank assets as follows.

Suppose for simplicity there are two banks ( 1 and 2 ) operating in two counties ( $A$ and $B$ ). From the SoD database we know the deposits of each bank in each county $\left(D_{1, A}, D_{1, B}, D_{2, A}, D_{2, B}\right)$ and from CR we know the total assets of each bank $\left(A_{1}, A_{2}\right)$. We want to estimate the distribution of assets across counties $\left(A_{1, A}, A_{1, B}, A_{2, A}, A_{2, B}\right)$.

We assume that each bank splits its assets in the two counties in the same proportion in which it holds its deposits:

\footnotetext{
${ }^{10}$ Noninterest expense less amortization of intangible assets in percent of net interest income plus noninterest income.
} 
$\frac{A_{1, A}}{D_{1, A}}=\frac{A_{1, B}}{D_{1, B}}$

$\frac{A_{2, A}}{D_{2, A}}=\frac{A_{2, B}}{D_{2, B}}$

We also know that

$A_{1, A}+A_{1, B}=A_{1}$

$A_{2, A}+A_{2, B}=A_{2}$

Equations (1) to (4) determine $A_{1, A}, A_{1, B}, A_{2, A}, A_{2, B}$ given $A_{1}, A_{2}$ and $D_{1, A}, D_{1, B}, D_{2, A}, D_{2, B}$. This calculation was performed for each year (1990 to 2020), and for all counties (about 3200, the number varies slightly over time) and banks (about 5200 today, the number declined sharply over time).

The crucial assumption behind this method is that the location of deposits is a good guide for the location of asset exposures; or in other words, that banks tend to lend largely in the counties where they collect deposits. This can be a strong assumption in particular if banks use the flexibility allowed by the liberalization of interstate banking (Riegle-Neal Act of 1994), not so much to move branches across state boundaries, but more to disconnect the location of funding sources from the location of the corresponding exposures. The next section contains a "quality check" of this assumption based on the location of residential real estate loans, which is available from HMDA data.

For the second and third groups of variables (business model and performance indicators) we apply the same method, using as reference the estimated location of assets obtained in the way just described. We have chosen this approach rather than the alternative of using as reference the location of deposits as done for example by Avery et al. (2003) to account for the fact that banks have different deposit/asset ratios as a result of different funding strategies. If deposit/asset ratios differ significantly across banks, the distribution of deposits leads to a biased estimate of the characteristics of the bank asset mix (as shown in Annex 4).

\section{Quality check}

As a quality check of our estimates, we compared our county-level breakdown of residential mortgages with the data on the location of residential mortgages provided by the HMDA database. HMDA data provide information on all home mortgage applications submitted to US financial institutions, including the outcome of the application (acceptance or denials, origination), the characteristics of the loan (amount, conditions), the identity of the financial institution and its regulatory agency, and the characteristics of the applicant and the collateral, including location.

Our check, though probably the best one can do, is far from exact for three main reasons. First, it is limited to home mortgages, while we apply our estimation method other exposures as well. This depends on data availability: no statistical source exists which provides information on other bank exposures of a level of detail comparable to that of HMDA for home mortgages. The other class of loans for which granular information exists is small business loans (SBL), from the CRA database. Jagtiani et al (2018), who like us use the location of deposits to infer the location of SBLs, perform a similar quality check (see Jagtiani et al, 2018 Appendix 1). Residential mortgages are more appropriate for our purpose because they account for a much larger share of bank loans (about 33 percent in 2019, 
as opposed to 8.0 percent for SBLs); at any rate, the pilot calculation they do on SBLs is also relevant as a check for what we do. Second, HMDA data refer to new loans, while our estimates refer to outstanding amounts. Outstanding loan amounts result from the cumulation of previous originations, until maturity, so there is a link between the two concepts; but the link is exact only if the geographical location of newly originated loans does not change over time. The third problem is that matching financial institutions across the two sources (FDIC Call Reports and HMDA data) is difficult because the coding systems are different and do not allow for an easy "crosswalk" from one to the other. We were able to establish a correspondence only for two years, 2018 and 2019, in which Legal Entity Identifiers are available in both sources for a large number of institutions, accounting for over 80 percent of outstanding loans. Therefore, our check is limited to those years and those financial institutions.

With these limitations in mind, and after having checked that the HMDA shares are indeed roughly constant between 2008 and 2009 (suggesting that stock- and flow-shares may not be too different) we proceeded by comparing, for each of the two years just mentioned, the share of outstanding home mortgages by a given financial institution in a given county from our estimates with the share of newly originated home mortgages by that same institution in that same county from the HMDA source. The comparison include mortgages for house purchase only, excluding those for construction. The relation in each of the two years is shown in the scatter plots of Figure 1. Our estimated (stock) shares are in the horizontal axis, the HMDA (flow) shares in the vertical exis.

While not all the (over 15.000) dots lie on or even close to the $45^{\circ}$ line, the interpolating line's slope is positive and highly significant ( $t$ statistic around 170 ). The cloud of points is particularly dense at low levels of the share, below 20 percent. The fact that slope coefficient is below unity (close to 0.6) may be explained by an errors-in-variable "attenuation" effect. Interestingly, the constant is small (around 1.4 percent) but also significantly positive, something which the errors-in-variable bias cannot explain (the constant is not asymptotically biased by errors in variable). This is probably due to the fact that some cross-county lending takes place anyway, even when banks do not collect any deposits locally. The standard error of the regression is in the order of 9 percent.

Our conclusion from this exercise is that, while deposit location is by no means an exact indicator of the geography of assets, it does contain a large amount of information on where residential mortgages are located. 
Figure 1

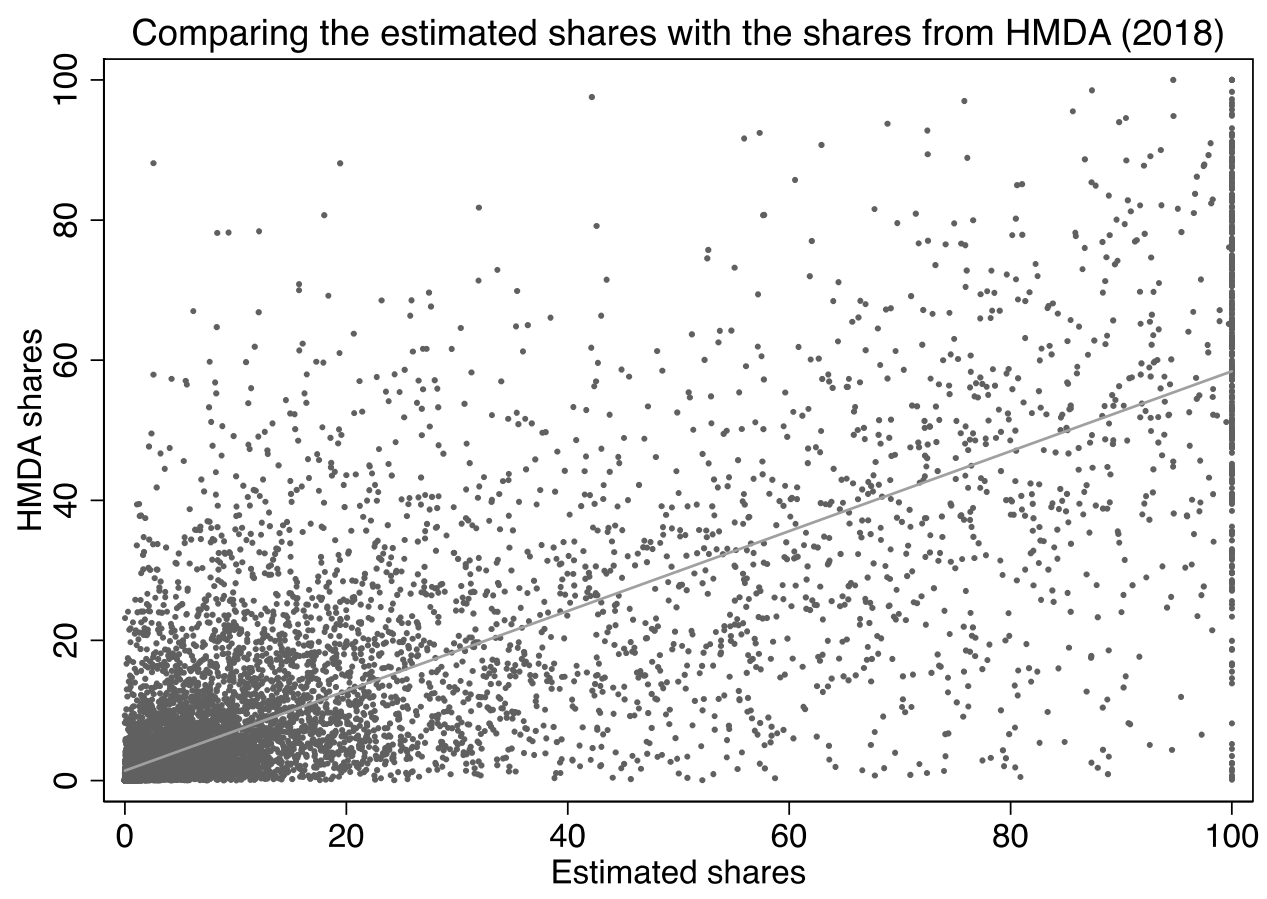

2018

HMDA shares

\begin{tabular}{|c|c|}
\hline Estimated shares & $0.570^{* * *}$ \\
\hline & $(0.00318)$ \\
\hline Constant & $1.421 * * *$ \\
\hline
\end{tabular}

SE of the regression $\quad 8.8877$ 


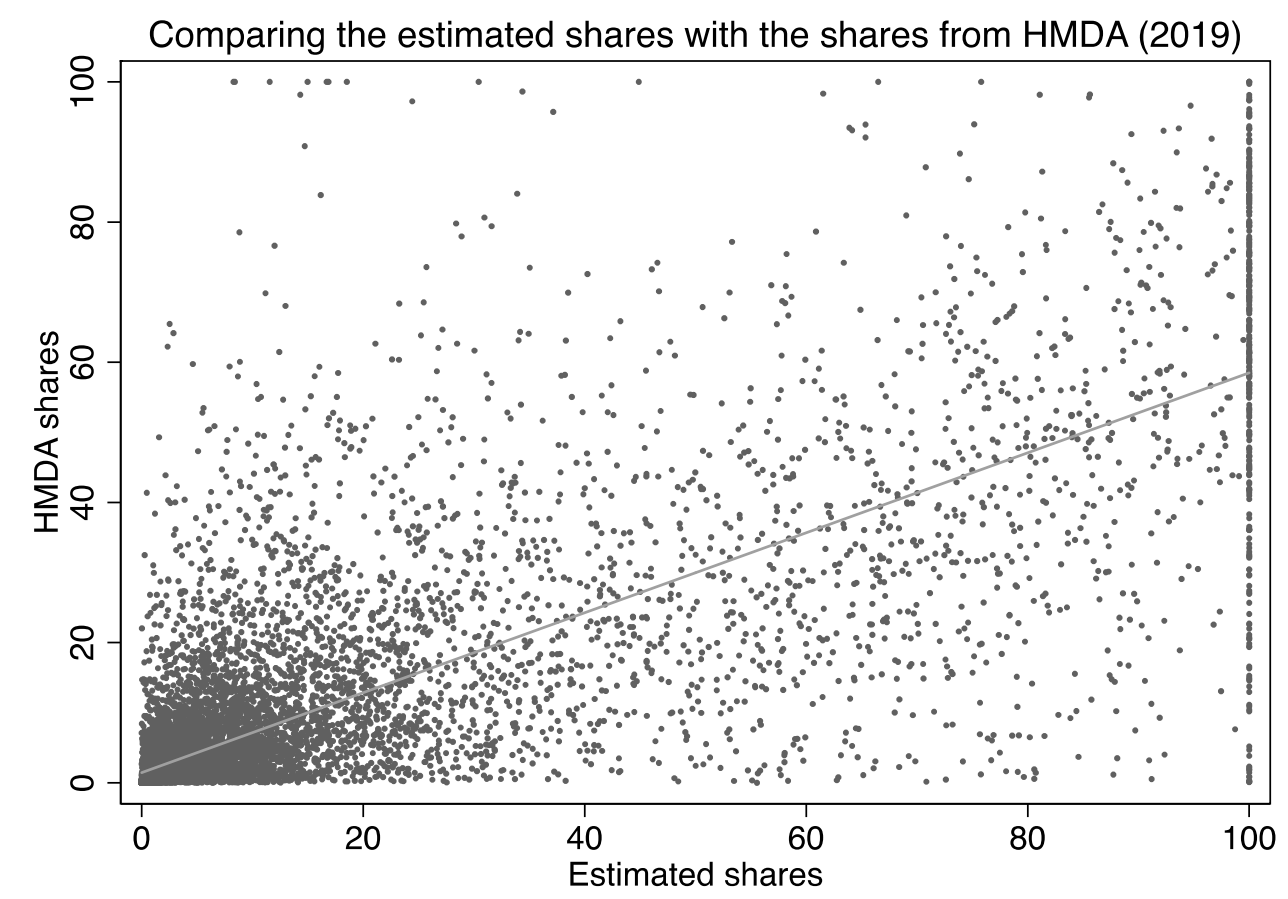

2019

HMDA shares

Estimated shares

$0.570 * * *$

(0.00336)

Constant

$1.465^{* * *}$

(0.0809)

SE of the regression

9.1898

$\mathrm{N}$

15736

\section{Stylized facts}

The data allows us to draw some stylized facts about the development of US Banking, with countylevel detail, over the period 1990-2020. The stylized facts we present here are purely descriptive and do not claim any causality. They are based on the summary statistics presented in Annexes 1 and 2, the maps and frequency distributions presented in Annex 3 and online Annex 5, and complement the synoptic table of Annex 6.

In what follows we refer to the "Midwest ridge", as the central region of the United States cutting North to South from the Dakotas to Texas. In addition, following a denomination used by Austin et al 
(2018) in a similar context, we refer to the "Heartland" as that area plus the region along the Mississippi river.

\section{Stylized Fact 1: Banks increased the number of counties they operate in.}

The average number of counties a bank operates in steadily increased, from 1.8 in 1990 to 5.1 in 2020 (see Annex 1 and Figure 1.2.). The distribution is strongly skewed to the left and peaks at the first bracket (operation in 1 county) in all years (see Figure C2). This implies that the vast majority of banks operate only in very few counties - local banking still dominates. However, the share of banks that only operate in one county decreased over time, from around $80 \%$ in 1990 to less than $40 \%$ in 2020 . Accordingly, the distribution flattens out and the standard deviation declines from 3.3 in 1990 to 23.7 in 2020 (see Annex 1). ${ }^{11}$

\section{Stylized Fact 2: The number of banks operating in each county varies strongly across regions.}

While the average number of banks per county remains rather constant over time, reaching a peak just before the Global Financial Crisis (henceforth GFC), there is considerable variation across regions. This heterogeneity remains rather stable throughout the observation period. The number of banks per county is lowest (1-3 banks per county) along the Midwest ridge, whereas it is highest (11 banks or more) in the West coast, Florida and New England as well as around the Great Lakes (see Figure C1). There are several states with large within-state differences in the number of banks operating in each of the state's counties, such as in Texas, Colorado and states in the Southwest.

\section{Stylized Fact 3: The "big 5" market share strongly increased in most counties with the highest shares at the East and West coast.}

The market share of the 5 largest US banks by assets ("big $5^{\text {"12) }}$ ) increases over time in nearly all counties. In the average county, the market share of the 5 largest banks rose from just $0.6 \%$ to over $13.9 \%$ in 2010 . The trend slightly reversed in the last decade with a market share of $11.2 \%$ in 2019 (see Annex 1 and Figure 1.5). We observe the same trend if shares are weighted by assets or population; this weighting yields considerable higher shares since bigger banks are concentrated in only few counties. In 2019 the mean share weighted by bank assets (population) was equal to $42.2 \%$ (33.3\%). As can be seen in Figure C5, the distribution peaks at the lowest bar, which represent a share of big bank assets less than $5 \%$. In 1990, the share of counties with a share of "big 5 " less than $5 \%$ was close to $100 \%$. This fraction decreased steadily until 2011 to around $53 \%$. Like the mean, the trend slowly reversed in more recent years.

The geographical distribution of the "big 5 " shares also shows major changes over time, especially in the 1990s, after the liberalization of interstate branching (Riegle-Neal Act). At the beginning of the 1990 s the share is high (20-100\%) only in California. Subsequently, it grows both in the West and in

\footnotetext{
${ }^{11}$ There are some banks that operate in a large number of branches that are not illustrated in the histogram. In 1990 , the number of counties covered by the bank with most branches was equal to 83 . This number increased to 580 in 2000 and 931 in 2010. the same trend is observable for other large banks. In recent years, the trend slightly reversed: in 2020, the largest bank operated in 857 counties (see maximum in Summary statistic table ${ }^{12}$ The composition of this group changes over time, being defined by the 5 largest banks by assets each year.
} 
the North-east. Towards the end of the sample the share is high in most of the West and at the East coast, including Florida, as well as in certain areas around the Great Lakes. It remains low in most of the Midwest, especially along the Midwest ridge.

\section{Stylized Fact 4: The market share of community banks shows a strong regional connotation, with many counties having either no community banks at all, or only community banks.}

The community banks' market share by assets in the average county decreased over time from 66.2 $\%$ to $54,4 \%$ in 2019 . The same trend is observable if the shares are weighted by assets and population (Annex 1 and Figure I.4). Throughout the period this distribution has two peaks, at the minimum (0$5 \%$ ) and the maximum (95-100\%), with the latter peak being higher (see Figure C4). This pattern evolves over time. In 1990, the percentage of counties with a community banks' market share of 95$100 \%$ lies around $35 \%$. It drops to around $25 \%$ at the end of the 1990 s before the trend slows down, stabilizing just above $20 \%$ in 2020 . The ratio of counties with a community banks' market share of 0 $5 \%$ increases slightly over time to above $10 \%$ in 2020.

The market share of community banks has a strong regional connotation throughout the period (see Figure (4): low or nil in the West, high in the Midwest Ridge, intermediate in the South-East and NorthEast. The pattern evolves over time: in the regions where the share is high initially, it tends to gradually decline. At the end of the observation period, the community banks' market share is low in the Northeast and the Southeast, with some exceptions, while it remains large along the Midwest Ridge.

\section{Stylized fact 5: Bank assets and deposits per capita increase over time on average, with a large dispersion across counties.}

Bank assets and deposits per capita in the average county steadily increased between 1990 and 2020, from around $\$ 12,400$ to $\$ 31,100$ and from $\$ 9,900$ to $\$ 23,500$, respectively (Annex 1 and Figure 1.6 and I.8). The geographical distributions are bell-shaped and skewed to the left throughout (see Figure C6 and (8). The distribution gets considerably more spread out over time, implying an increasing variation across counties; the standard deviation rises, between 1990 to 2019 , from $\$ 9,000$ to $\$ 124,400$ for bank assets and from $\$ 5,200$ to $\$ 66,200$ for bank deposits per capita. Part of this change may be related to changes in real values due to inflation.

As can be seen in Figure $\mathrm{C} 6$ and $\mathrm{C} 8$, the highest ratios can be found along the Californian coast, along the Midwest Ridge and in the Northeast. This heterogeneity pattern persists over time, even if per capita bank assets and deposits increase on average. In 2020, most counties have ratios in the highest quintile, based on the year 2005. Here again, changes in real values may explain these movements.

\section{Stylized fact 6: Bank assets and deposits-to-GDP ratios are highest in the Heartland, and decline over time on average.}

Bank deposits and assets to GDP ratios are slightly decreasing throughout the observation period in the average county. The distribution across counties is bell shaped and slightly skewed to the left throughout. The distribution seems to get slightly more symmetric and a little less spread out over time for bank assets, implying that there are fewer counties with very high bank assets to GDP ratios $(>125 \%)$. However, in general both distributions remain rather stable between the mid-90s and the 
end of our observation period. Accordingly, the regional heterogeneity is also quite stable. The largest ratios can be found in counties with large financial centers, such as in counties in the Northeast, Florida and around the San Francisco area and throughout the Heartland (see Figure C7 and C9).

\section{Stylized fact 7: The composition of bank lending is shifting away from agricultural and small business loans and towards household lending, mainly for real estate.}

We observe a clear shift in business models over the observation period. The share of agricultural loans in the average county steadily decreased from $9.5 \%$ in 1990 to $4.9 \%$ in 2020. Similarly, the share of small business loans (proxied by commercial and industrial loans below $\$ 1 \mathrm{mn}$ ) decrease from $10.6 \%$ in $1993^{13}$ to $5.9 \%$ in 2019. In 2020, there is a considerable rise in the share of small business loans throughout the US, probably connected with the Covid emergency (see Annex 1 and 2). ${ }^{14}$ The distribution of small business and agricultural loans shares across counties is skewed to the left (see Figure $\mathrm{C} 10$ and C12), which is attributable to the fact that many counties, particularly in the East, have very little or no agricultural loans. By contrast, the share of real estate loans in the average county increase from $52.5 \%$ in 1990 to $67.4 \%$ in 2009 . After the GFC the share of real estate loans in the average county drops, but then remains rather stable around 64\% (a share well above the levels of the 1990s).

Stylized fact 8: Bank business models in the Heartland are characterized by a relatively large share of agricultural and small business loans and a lower levels of real estate loans.

There is a considerable regional connotation regarding bank business models (see Figure C10-C14). At the beginning of our observation period, the share of small business loans is high (11-31\%) in the whole Midwest and in large areas of the West and East. Towards the end of the sample, it is high only along the Midwest ridge. Similarly, the share of agricultural loans is initially high (9-85\%) in all Midwestern regions, and medium-high (2-9\%) throughout the West; then it progressively declines. Towards the end of the period, it remains high only in the Midwest ridge and along the Mississippi River, whereas in the West and in some parts of the South-East it is medium-high.

By contrast, the share of real estate loans starts very low but rises steadily, first in the West Coast and some "clusters" (Colorado, New Mexico), plus most of the East. Before the GFC the share is high (75\% or above) in large parts of the country, but then declines. The only area in which it stays low throughout (in relative terms, at $57 \%$ or less) is the Midwest ridge.

Stylized fact 9: Non-interest income to asset ratios are highest in the West with initially large, but disappearing, differences between neighboring counties across state borders.

The non-interest income to asset ratio in the average county increased in the 90 s from $0.9 \%$ in 1990 to $1.3 \%$ in 2000 . The ratio remained rather constant in the 2000 s and decreased again in the last

\footnotetext{
${ }^{13}$ Data for 1990-1992 are not available.

${ }^{14}$ We deleted observations, presumably mistaken, in which the share of small business loans is greater than $100 \%$.
} 
decade (see Annex 1 and Figure II.5). For the entire observation period, counties with the highest ratios are located in the West, while the lowest ratios can be found in the Heartland.

Throughout the 1990s, there are considerable differences in ratios between neighboring counties across state borders, perhaps linked to interstate differences in bank regulations. The most pronounced differences can be found along the Eastern borders of Arizona, Utah and Idaho, which separates counties with high ratios throughout the West and counties with lower ratios in the middle of the country. Another example is found at the Northern borders of Tennessee and North Carolina, separating counties with higher ratios in the Southeast from counties with lower ratios in the Northeast. After the GFC, these differences cease to exist (see Figure C14).

\section{Stylized fact 10: Dispersion in leverage is large before the GFC but converges towards higher levels in 2010s.}

The (inverted) leverage ratio in the average county increased over the observation period, from $7.7 \%$ to $10.7 \%$ with a small dip before the GFC. In the early 1990 s the ratio is in the highest brackets (above $10 \%$ ) only in the Midwest and in certain areas of the East, whereas in the West and at the East coast it is lower (see Figure C16). In the years before the GFC, there is a considerable increase in the standard deviation across counties, with extreme (inverted) leverage ratios in some counties (see Annex 1 and Figure III.2). In general, the dispersion across counties is quite large before the GFC. Starting in 2009, the ratio quickly moves up in the whole country, presumably due to the post-crisis tightening of capital regulation, and the ratios across counties converge. Interstate differences also tend to vanish.

\section{Stylized fact 11: Cost efficiency ratios within counties show no clear regional pattern and are rather volatile over time.}

In the early 90s, cost efficiency ratios decreased in nearly all counties and stayed around $60 \%$ on average until the GFC. Between 2009 and 2011, the average cost efficiency ratio moves up to 68\% with a reversing trend in recent years (see Annex 1 and Figure III.3). Starting in the late 90s and until 2007 ratios are rather small in the West and comparably large in the Midwest and some counties in the South and Northeast. There is no clear regional pattern in cost efficiency ratios (see Figure C17). In some years there are significant changes in some states, leading to differences between neighboring counties across state borders. For instance: in 1996 cost efficiency levels in California are noticeable larger compared to years before and afterwards. In 2000 a similar change is observable in Arizona and Utah.

\section{Stylized Fact 12: The net interest margin declined over time in most counties, but remained relatively stable in the Heartland.}

After a small increase in the early years, the net interest margin in the average county gradually decreased, between 1993 and 2020 from around 4.5\% to 3.4\%, in connection with the trend decline in the general level of interest rates. The variation across counties, as measured by the standard deviation, increased before the GFC and dropped afterwards (see Annex 1 and Figure III.5).

The margin is high everywhere at the beginning of our period, especially in the West and certain areas of the East. After the GFC it moves lower, especially in certain areas of the West. Towards the end of 
the sample the lowest levels are in the West and part of the East and the South-East. Overall, the counties in the Midwest ridge exhibit a more stable NIM over time (see Figure C19).

\section{Stylized Fact 13: The GFC left a deep mark on banking performance measures.}

The GFC strongly, but temporarily, affected banking performance measures in nearly all counties. The non-performing asset ratio in the average county jumped upwards, from around $0.7 \%$ in the early 2000 s to $3.2 \%$ in $2009 / 2010$. In 2020 these levels were back to pre-crisis levels - data in that year do not reflect the Covid crisis yet. Similarly, the pre-tax return on assets dropped from around 1.7-1.8\% in pre-crisis years to $0.3 \%$ in 2009 . The return-on-assets recovered in $2010 \mathrm{~s}$, however, still remain below pre-crisis levels (see Annex 1 and 2).

\section{Conclusions and work ahead}

We believe that the data presented in this paper can help analyse several features of the recent US economic history, in particular how banking sector developments and policies have contributed to shape the country's economic and social progress, its diversity across regions and its imbalances and failures.

Discussing how this can be done goes beyond our scope here. Three areas, however, come to mind.

First, any observer of US recent developments is struck by the parallel decline, over the recent decades, of the economic and social conditions in certain areas of the country and of the banking sectors serving those area. Our data are extensive and detailed enough not only to document and measure this relation but also to uncover any underlying causal linkages. Of special interest is to understand how landmark legislative reforms, such as the liberalization of interstate branching and the protection accorded to local and community banking, have affected the way banks influence economic and social progress in those areas.

Second, the data can be used to explore the impact of the Great Financial Crisis with added geographical detail. A body of banking literature and much popular discourse have surmised that small and community banks with retail-oriented business models are in a better position to protect local economies and communities from adverse shocks. This hypothesis has been tested in several ways but never in a geographical dimension. Again, our data are sufficiently comprehensive to do that and also allow to compare the experience of the GFC with that of earlier - though milder - economc recessions.

Thirdly, our data will permit to analyse the effects of the Covid crisis on both the local economies and the local banking sectors. For this purpose, more observations will be needed. Banking indicators for 2020, affected by Covid, are already included in our estimates, but county-level real sector data for 2020 will only be released in December 2021. Data for 2021 will become available in two steps: April 2022 for banking data, and December 2022 for real sector data.

We plan to put our data in the public domain, but not immediately. As a first step, we will contact a small number of scolars involved in banking and inequality studies, offering our data to them and their students for research and dissertation work. This will help us test the data and uncover ways in which they can be refined and developed further. In parallel, we will conduct analyses on our own and 
additional quality checks. After this phase, which should last some 12 months, we will make our data public.

Readers of these lines who wish use our data for their research are welcome to contact us at the email addresses listed in the front page. 


\section{References:}

Acharya, V. V., Borchert L., Jager M., \& Steffen S. (forthcoming). Kicking the can down the road: government interventions in the European banking sector, Review of Financial Studies, forthcoming.

Acharya, V. V., Eisert, T., Eufinger, C., \& Hirsch, C. (2019). Whatever it takes: The real effects of unconventional monetary policy. The Review of Financial Studies, 32(9), 3366-3411.

Aghion, P., Howitt, P., \& Mayer-Foulkes, D. (2005). The effect of financial development on convergence: Theory and evidence. The Quarterly Journal of Economics, 120(1), 173-222.

Arcand, J. L., Berkes, E., \& Panizza, U. (2015). Too much finance?. Journal of Economic Growth, 20(2), 105-148.

Agarwal, S., Bennmelech, E., Bergman N. \& Seru A. (2012). Did the Community Reinvestment Act (CRA) Lead to Risky Lending?, NBER Working paper 18609, 2012

Austin, B., Glaeser A. \& Summers, L. H. (2018). Saving the heartland: place-based policies in 21st Century America; Brookings Papers on Economic Activity.

Avery, R. B., Calem P.S. \& Canner G.B. (2003). The Effects of the Community Reinvestment Act on Local Communities. Federal Reserve Board, Division of Research and Statistics Working Paper, 2003

Bagehot, W. (1873). Lombard street: A description of the money market. McMaster University archive for the history of economic thought: History of economic thought books.

Beck, T. (2013a): Finance and growth: Too much of a good thing? 27 October (VoxEU) Available at: https://voxeu.org/article/finance-and-growth (Accessed 15 June 2021)

Beck, T. (2013b). Bank Financing for SMEs-Lessons from the Literature. National Institute Economic Review, 225(1), R23-R38.

Beck, T., Büyükkarabacak, B., Rioja, F. K., \& Valev, N. T. (2012). Who gets the credit? And does it matter? Household vs. firm lending across countries. The BE Journal of Macroeconomics, 12(1).

Beck, T., Demirguc-Kunt, A. S. L. I., Laeven, L., \& Levine, R. (2008). Finance, firm size, and growth. Journal of Money, Credit and Banking, 40(7), 1379-1405.

Beck, T., Demirgüç-Kunt, A., \& Levine, R. (2007). Finance, inequality and the poor. Journal of economic growth, 12(1), 27-49.

Beck, T., Demirgüç-Kunt, A., \& Levine, R. (2010a). Financial institutions and markets: Across countries and over time. World Bank Economic Review,24(1), 77-92

Beck, T., Demirgüç-Kunt, A. S. L. I., \& Maksimovic, V. (2005). Financial and legal constraints to growth: does firm size matter?. The Journal of Finance, 60(1), 137-177.

Beck, R., Georgiadis, G., \& Straub, R. (2014). The finance and growth nexus revisited. Economics Letters, 124(3), 382-385.

Beck, T., \& Levine, R. (Eds.). (2018). Handbook of Finance and Development. Cheltenham, UK: Edward Elgar Publishing.

Beck, T., Levine, R., \& Levkov, A. (2010b). Big bad banks? The winners and losers from bank deregulation in the United States. The Journal of Finance, 65(5), 1637-1667.

Beck, T., Levine, R., \& Loayza, N. (2000). Finance and the sources of growth. Journal of Financial Economics, 58(1-2), 261-300. 
Berger, A. (1995). The Profit-Structure Relationship in Banking--Tests of Market-Power and Efficient Structure Hypotheses, Journal of Money, Credit and Banking , Vol. 27, No. 2, pp. 404-431

Berger, A. N., \& Udell, G. F. (2002). Small business credit availability and relationship lending: The importance of bank organisational structure. The Economic Journal, 112(477), F32-F53.

Berger, A., Demirgüç-Kunt, A., Levine, R., \& Haubrich, J. (2004). Bank Concentration and Competition: An Evolution in the Making. Journal of Money, Credit and Banking, Vol. 36, No. 3, pp. 433-451.

Berger, A. N., \& Udell, G. F. (2006). A more complete conceptual framework for SME finance. Journal of Banking \& Finance, 30(11), 2945-2966.

Berger, A. N., \& Bouwman, C. H. (2013). How does capital affect bank performance during financial crises?. Journal of Financial Economics, 109(1), 146-176.

Berger, A. N., Goulding, W., \& Rice, T. (2014). Do small businesses still prefer community banks?. Journal of Banking \& Finance, 44, 264-278.

Berger, A. N., Cerqueiro, G., \& Penas, M. F. (2015). Market size structure and small business lending: Are crisis times different from normal times?. Review of Finance, 19(5), 1965-1995.

Berger, A. N., Bouwman, C. H., \& Kim, D. (2017). Small bank comparative advantages in alleviating financial constraints and providing liquidity insurance over time. The Review of Financial Studies, 30(10), 3416-3454.

Berger, A. N., \& Roman, R. A. (2018). "Finance and the real economy: Evidence from the US". In Handbook of Finance and Development. Cheltenham, UK: Edward Elgar Publishing.

Benczúr, P., Karagiannis, S., \& Kvedaras, V. (2019). Finance and economic growth: financing structure and non-linear impact. Journal of Macroeconomics, 62, 1030-48.

Bezemer, D., Grydaki, M., \& Zhang, L. (2016). More mortgages, lower growth?. Economic Inquiry, 54(1), 652-674.

Black, S. E., \& Strahan, P. E. (2002). Entrepreneurship and bank credit availability. The Journal of Finance, 57(6), 2807-2833.

Black, K.W. (2013). The latest failed effort to blame the Community Reinvestment Act for Accounting Control Fraud, New Economic Perspective blog.

Boot, A. W., \& Thakor, A. V. (2000). Can relationship banking survive competition?. The Journal of Finance, 55(2), 679-713.

Burgess, R., \& Pande, R. (2005). Do rural banks matter? Evidence from the Indian social banking experiment. American Economic Review, 95(3), 780-795.

Caballero, R. J., Hoshi, T., \& Kashyap, A. K. (2008). Zombie lending and depressed restructuring in Japan. American Economic Review, 98(5), 1943-77.

Cecchetti, S. G. \& Kharroubi, E. (2012) Reassessing the impact of finance on growth, BIS working paper no. 381.

Chava, S., Oettl, A., Subramanian, A., \& Subramanian, K. V. (2013). Banking deregulation and innovation. Journal of Financial economics, 109(3), 759-774.

Choi, B. P., \& Weiss, M. A. (2005). An empirical investigation of market structure, efficiency, and performance in property-liability insurance. Journal of Risk and Insurance, 72(4), 635-673.

Claessens, S., \& Laeven, L. (2003). Financial development, property rights, and growth. the Journal of Finance, 58(6), 2401-2436.

Claessens, S., \& Laeven, L. (2005). Financial dependence, banking sector competition, and economic growth. Journal of the European Economic Association, 3(1), 179-207. 
Cole, R. A., Goldberg, L. G., \& White, L. J. (2004). Cookie Cutter vs. Character: The Micro Structure of Small Business Lending by Large and Small Banks. Journal of Financial \& Quantitative Analysis, 39(2).

Dell'Ariccia, G., Detragiache, E., \& Rajan, R. (2008). The real effect of banking crises. Journal of Financial Intermediation, 17(1), 89-112.

Demirgüç-Kunt, A., Laeven L. \& Levine R., (2004). "Regulations, Market Structure, Institutions, and the Cost of Financial Intermediation" Journal of Money, Credit and Banking, Vol. 36, No. 3, pp. 593622

Demirgüç-Kunt, A., \& Levine, R. (2009). Finance and inequality: Theory and evidence. Annual Review of Financial Economics, 1(1), 287-318.

Demirgüç-Kunt, A., \& Huizinga, H. (2010). Bank activity and funding strategies: The impact on risk and returns. Journal of Financial Economics, 3(98), 626-650.

Demirguc-Kunt, A., Detragiache, E., \& Merrouche, O. (2013). Bank capital: Lessons from the financial crisis. Journal of Money, Credit and Banking, 45(6), 1147-1164.

Demetriades, P. O., \& Rousseau, P. L. (2016). The changing face of financial development. Economics Letters, 141, 87-90.

Duqi, A., Tomaselli, A., \& Torluccio, G. (2018). Is relationship lending still a mixed blessing? A review of advantages and disadvantages for lenders and borrowers. Journal of Economic Surveys, 32(5), 1446-1482.

Feldman, M. P. \& Langford, S, (2019). We Miss You George Bailey: The Effect of Local Banking Conditions on the County-Level Timing of the Great Recession. Available at SSRN: https://ssrn.com/abstract=3501746 (Accessed 15.06.2021)

Fisman, R., \& Love, I. (2007). Financial dependence and growth revisited. Journal of the European Economic Association, 5(2-3), 470-479.

Guiso, L., Sapienza, P., \& Zingales, L. (2004a). Does local financial development matter?. The Quarterly Journal of Economics, 119(3), 929-969.

Guiso, L., Jappelli, T., Padula, M., \& Pagano, M. (2004b). Financial market integration and economic growth in the EU. Economic Policy, 19(40), 524-577.

Hasan, I., Koetter, M., \& Wedow, M. (2009). Regional growth and finance in Europe: Is there a quality effect of bank efficiency?. Journal of Banking \& Finance, 33(8), 1446-1453.

Hendrickson, C., Muro, M. \& Galston W. A. (2018). Countering the geography of discontent. Strategies for left-behind places, Brookings, November 2018.

Jagtiani, J. \& Lemieux C. (2016). Small business lending after the financial crisis: A new competitive landscape for community banks, Economic Perspectives, Federal Reserve Bank of Chicago, 3.

Jagtiani, J. \& Maingi R. Q. (2018). How Important Are Local Community Banks to Small Business Lending? Evidence from Mergers and Acquisitions. Working paper 18-18, Federal Reserve Bank ofPhiladelphia.

Jayakumar, M., Pradhan, R. P., Dash, S., Maradana, R. P., \& Gaurav, K. (2018). Banking competition, banking stability, and economic growth: Are feedback effects at work?. Journal of Economics and Business, 96, 15-41.

Jokipii, T., \& Monnin, P. (2013). The impact of banking sector stability on the real economy. Journal of International Money and Finance, 32, 1-16. 
Jordà, Ò., Schularick, M., \& Taylor, A. M. (2011). Financial crises, credit booms, and external imbalances: 140 years of lessons. IMF Economic Review, 59(2), 340-378.

Kaminsky, G. L., \& Reinhart, C. M. (1999). The twin crises: the causes of banking and balance-ofpayments problems. American economic review, 89(3), 473-500.

Karlan, D., \& Zinman, J. (2010). Expanding credit access: Using randomized supply decisions to estimate the impacts. The Review of Financial Studies, 23(1), 433-464.

Kasinger, J., Krahnen, J. P., Ongena, S., Pelizzon, L., Schmeling, M., \& Wahrenburg, M. (2021). Nonperforming loans-new risks and policies? NPL resolution after COVID-19: Main differences to previous crises. SAFE White Paper 84.

Kim, D., \& Sohn, W. (2017). The effect of bank capital on lending: Does liquidity matter?. Journal of Banking \& Finance, 77, 95-107.

King, R. G., \& Levine, R. (1993). Finance and Growth: Schumpeter Might be Right. The Quarterly Journal of Economics, 108(3), 717-737.

Klein, M. A. (1971). A theory of the banking firm. Journal of money, credit and banking, 3(2), 205-218.

La Porta, R., Lopez-de-Silanes, F., \& Shleifer, A. (2002). Government ownership of banks. The Journal of Finance, 57(1), 265-301.

Laeven, L. \& Valencia F. (2018): Systemic banking crises revisited, IMF Working Paper WP/18/206.

Levine, R., Loayza, N., \& Beck, T. (2000). Financial intermediation and growth: Causality and causes. Journal of monetary Economics, 46(1), 31-77.

Levine, R. (2005) "Finance and Growth: Theory and Evidence." in Handbook of Economic Growth, ed. Philippe Aghion and Steven N. Durlauf, 865-934. Amsterdam: Elsevier.

Lloyd-Williams, D. M., Molyneux P., \& Thornton, J., (1994). Market structure and performance in Spanish banking, Journal of Banking \& Finance, 18, (3), pp. 433-443

Loayza, N. V., \& Ranciere, R. (2006). Financial development, financial fragility, and growth. Journal of Money, Credit \& Banking, 38(4), 1051-1077.

Marquez, R. (2002). Competition, adverse selection, and information dispersion in the banking industry. The Review of Financial Studies, 15(3), 901-926.

Mehran, H., \& Thakor, A. (2011). Bank capital and value in the cross-section. The Review of Financial Studies, 24(4), 1019-1067.

Miles, D., Yang, J., \& Marcheggiano, G. (2013). Optimal bank capital. The Economic Journal, 123(567), 1-37.

Moretti, E. (2012). The New Geography of Jobs, Houghton Mifflin.

Petersen, M. A., \& Rajan, R. G. (1995). The effect of credit market competition on lending relationships. The Quarterly Journal of Economics, 110(2), 407-443.

Popov, A. (2018). "Evidence on finance and economic growth". In Handbook of Finance and Development. Cheltenham, UK: Edward Elgar Publishing.

Powell, J. H. (2016). "Trends in Community Bank Performance over the Past 20 Years", speech at the "Community Banking in the 21st Century" Fourth Annual Community Banking Research and Policy Conference, St. Louis Missouri, 29 September 2016.

Rajan, R. G., \& Zingales, L. (1998). Financial dependence and growth. The American Economic Review, 88(3), 559. 
Rodriguez-Pose, A. (2018). The revenge of the places that don't matter, Vox CEPR Policy Portal, 6 February.

Sassi, S., \& Gasmi, A. (2014). The effect of enterprise and household credit on economic growth: New evidence from European union countries. Journal of Macroeconomics, 39, 226-231.

Schumpeter, J. A. (1911). A theory of economic development. Cambridge, MA: Harvard University Press

Scott, J. A. (2004). Small business and the value of community financial institutions. Journal of Financial Services Research, 25(2), 207-230.

Valickova, P., Havranek, T., \& Horvath, R. (2015). Financial development and economic growth: A meta-analysis. Journal of Economic Surveys, 29(3), 506-526.

Zarutskie, R. (2006). Evidence on the effects of bank competition on firm borrowing and investment. Journal of Financial Economics, 81(3), 503-537.

Zhang, R., \& Naceur, S. B. (2019). Financial development, inequality, and poverty: Some international evidence. International Review of Economics \& Finance, 61, 1-16.

Zingales, L. (2015). Presidential address: Does finance benefit society?. The Journal of Finance, 70(4), 1327 
Annex 1: Summay statistics (tables)

Summary statistics: 1990

\begin{tabular}{|c|c|c|c|c|c|c|c|c|c|c|c|c|}
\hline & \multirow[b]{2}{*}{ Variable } & \multicolumn{5}{|c|}{ mean (1) } & \multirow{2}{*}{ sd } & \multirow{2}{*}{$\min$} & \multirow{2}{*}{ p25 } & \multirow{2}{*}{ p50 } & \multirow{2}{*}{ p75 } & \multirow{2}{*}{$\max$} \\
\hline & & simple & land & pop. & GDP & asset & & & & & & \\
\hline \multicolumn{13}{|c|}{ Structure } \\
\hline 1 & Number of banks & 8.4 & 7.5 & 43.8 & 54.1 & 63.8 & 12.3 & 1.0 & 3.0 & 6.0 & 9.0 & 329.0 \\
\hline 2 & Number of counties a bank operates in (2) & 1.8 & n.a. & n.a. & n.a. & n.a. & 3.3 & 1.0 & 1.0 & 1.0 & 1.0 & 83.0 \\
\hline 3 & Share of the largest bank by assets (\%) & 42.9 & 48.6 & 26.8 & 25.5 & 25.0 & 21.4 & 7.7 & 27.6 & 37.3 & 52.1 & 100.0 \\
\hline 4 & Share of community banks by assets (\%) & 66.2 & 50.5 & 38.2 & 32.9 & 30.1 & 32.5 & 0.0 & 38.1 & 71.9 & 100.0 & 100.0 \\
\hline 5 & Share of top 5 US banks by assets (\%) & 0.6 & 1.2 & 3.7 & 5.1 & 9.6 & 4.4 & 0.0 & 0.0 & 0.0 & 0.0 & 60.7 \\
\hline 6 & Per capita deposits (\$ Thou.) & 9.9 & 8.2 & 12.6 & 16.7 & 25.3 & 5.2 & 0.1 & 6.8 & 9.0 & 11.9 & 108.7 \\
\hline 7 & Deposits to GDP ratio (\%) & 68.3 & 53.2 & 55.8 & 54.8 & 64.0 & 33.4 & 0.7 & 45.3 & 62.3 & 85.1 & 454.3 \\
\hline 8 & Per capita assets (\$ Thou.) & 12.4 & 10.3 & 18.4 & 29.0 & 53.7 & 9.0 & 0.1 & 8.3 & 11.2 & 14.8 & 314.7 \\
\hline 9 & Assets to GDP ratio (\%) & 84.5 & 66.5 & 76.4 & 80.2 & 106.1 & 42.1 & 0.9 & 57.2 & 78.1 & 103.4 & 680.2 \\
\hline \multicolumn{13}{|c|}{ Business model } \\
\hline 1 & Share of agricultural loans (\%) & 9.5 & 8.7 & 1.9 & 1.4 & 1.4 & 14.5 & 0.0 & 0.4 & 2.7 & 12.0 & 84.5 \\
\hline 2 & Share of commercial and industrial loans (\%) & 16.6 & 20.9 & 19.7 & 21.1 & 22.6 & 6.9 & 0.0 & 11.8 & 15.9 & 20.5 & 64.5 \\
\hline 3 & Share of commercial and industrial loans below \$1 mio (\%) & n.a. & n.a. & n.a. & n.a. & n.a. & n.a. & n.a. & n.a. & n.a. & n.a. & n.a. \\
\hline 4 & Share of real estate loans (\%) & 52.5 & 46.2 & 57.5 & 56.3 & 53.3 & 14.4 & 1.0 & 44.1 & 54.3 & 62.4 & 99.2 \\
\hline 5 & Non-interest income to asset ratio (\%) & 0.9 & 1.0 & 1.2 & 1.2 & 1.4 & 0.6 & -0.4 & 0.6 & 0.8 & 1.1 & 14.7 \\
\hline \multicolumn{13}{|c|}{ Performance } \\
\hline 1 & Common Equity Tier 1 ratio (\%) & n.a. & n.a. & n.a. & n.a. & n.a. & n.a. & n.a. & n.a. & n.a. & n.a. & n.a. \\
\hline 2 & Leverage ratio (\%) & 7.7 & 7.6 & 6.1 & 5.9 & 5.8 & 2.1 & 1.6 & 6.3 & 7.4 & 8.8 & 21.5 \\
\hline 3 & Efficiency Ratio (\%) (3) & 68.8 & 66.0 & 72.2 & 72.3 & 72.2 & 53.8 & 16.1 & 61.4 & 66.1 & 71.6 & 2910.6 \\
\hline 4 & Pretax Return on Assets (\%) & 1.0 & 1.1 & 0.6 & 0.5 & 0.5 & 0.7 & -4.6 & 0.7 & 1.1 & 1.5 & 4.6 \\
\hline 5 & Net Interest Margin (\%) & 3.9 & 4.1 & 3.6 & 3.6 & 3.5 & 0.8 & -2.7 & 3.6 & 3.9 & 4.3 & 12.4 \\
\hline 6 & Non-performing assets ratio (\%) & 2.1 & 2.1 & 2.9 & 3.0 & 3.2 & 2.0 & 0.0 & 1.0 & 1.5 & 2.4 & 20.2 \\
\hline
\end{tabular}

Summary statistics: 1991

\begin{tabular}{|c|c|c|c|c|c|c|c|c|c|c|c|c|}
\hline & \multirow[b]{2}{*}{ Variable } & \multicolumn{5}{|c|}{ mean (1) } & \multirow{2}{*}{ sd } & \multirow{2}{*}{$\min$} & \multirow{2}{*}{ p25 } & \multirow{2}{*}{ p50 } & \multirow{2}{*}{ p75 } & \multirow{2}{*}{$\max$} \\
\hline & & simple & land & pop. & GDP & asset & & & & & & \\
\hline \multicolumn{13}{|c|}{ Structure } \\
\hline 1 & Number of banks & 8.2 & 7.4 & 41.9 & 51.2 & 60.3 & 11.7 & 1.0 & 3.0 & 6.0 & 9.0 & 314.0 \\
\hline 2 & Number of counties a bank operates in (2) & 1.8 & n.a. & n.a. & n.a. & n.a. & 3.4 & 1.0 & 1.0 & 1.0 & 1.0 & 83.0 \\
\hline 3 & Share of the largest bank by assets (\%) & 43.1 & 48.5 & 27.3 & 26.1 & 25.5 & 21.2 & 6.7 & 28.1 & 37.8 & 52.2 & 100.0 \\
\hline 4 & Share of community banks by assets (\%) & 66.2 & 50.4 & 38.0 & 32.9 & 30.1 & 32.5 & 0.0 & 38.4 & 71.8 & 100.0 & 100.0 \\
\hline 5 & Share of top 5 US banks by assets (\%) & 0.6 & 1.3 & 4.0 & 5.2 & 10.2 & 4.7 & 0.0 & 0.0 & 0.0 & 0.0 & 88.9 \\
\hline 6 & Per capita deposits (\$ Thou.) & 10.0 & 8.3 & 12.3 & 15.7 & 24.2 & 5.2 & 0.1 & 6.9 & 9.2 & 12.1 & 99.1 \\
\hline 7 & Deposits to GDP ratio (\%) & 67.8 & 52.8 & 53.6 & 52.2 & 62.2 & 34.0 & 0.8 & 44.7 & 61.5 & 84.7 & 471.2 \\
\hline 8 & Per capita assets (\$ Thou.) & 12.4 & 10.3 & 17.8 & 27.2 & 53.9 & 8.8 & 0.2 & 8.4 & 11.2 & 14.8 & 314.6 \\
\hline 9 & Assets to GDP ratio (\%) & 82.7 & 64.9 & 72.7 & 76.0 & 105.6 & 41.0 & 1.1 & 56.0 & 76.1 & 101.8 & 606.5 \\
\hline \multicolumn{13}{|c|}{ Business model } \\
\hline 1 & Share of agricultural loans (\%) & 9.9 & 9.1 & 2.0 & 1.5 & 1.5 & 14.9 & 0.0 & 0.5 & 2.7 & 12.8 & 84.9 \\
\hline 2 & Share of commercial and industrial loans (\%) & 15.8 & 19.4 & 18.8 & 20.1 & 21.7 & 6.6 & 0.4 & 11.3 & 15.0 & 19.5 & 66.0 \\
\hline 3 & Share of commercial and industrial loans below \$1 mio (\%) & n.a. & n.a. & n.a. & n.a. & n.a. & n.a. & n.a. & n.a. & n.a. & n.a. & n.a. \\
\hline 4 & Share of real estate loans (\%) & 53.6 & 47.2 & 58.3 & 57.0 & 53.6 & 14.8 & 2.6 & 45.3 & 55.6 & 64.1 & 98.8 \\
\hline 5 & Non-interest income to asset ratio (\%) & 0.9 & 1.1 & 1.3 & 1.3 & 1.5 & 0.6 & 0.0 & 0.6 & 0.8 & 1.1 & 13.6 \\
\hline \multicolumn{13}{|c|}{ Performance } \\
\hline 1 & Common Equity Tier 1 ratio (\%) & n.a. & n.a. & n.a. & n.a. & n.a. & n.a. & n.a. & n.a. & n.a. & n.a. & n.a. \\
\hline 2 & Leverage ratio (\%) & 8.0 & 8.1 & 6.6 & 6.4 & 6.3 & 2.0 & 2.2 & 6.6 & 7.7 & 9.0 & 22.2 \\
\hline 3 & Efficiency Ratio (\%) (3) & 66.5 & 65.2 & 68.1 & 67.2 & 69.1 & 10.8 & -122.9 & 61.0 & 65.4 & 70.4 & 210.6 \\
\hline 4 & Pretax Return on Assets (\%) & 1.2 & 1.2 & 0.8 & 0.7 & 0.7 & 0.7 & -3.9 & 0.9 & 1.2 & 1.5 & 5.2 \\
\hline 5 & Net Interest Margin (\%) & 4.1 & 4.3 & 3.9 & 3.8 & 3.8 & 0.6 & -2.2 & 3.8 & 4.1 & 4.4 & 12.7 \\
\hline 6 & Non-performing assets ratio (\%) & 1.9 & 1.8 & 2.9 & 3.1 & 3.2 & 1.6 & 0.0 & 0.9 & 1.5 & 2.3 & 18.5 \\
\hline
\end{tabular}

(1) Cross-county mean; respectively, unweighted and weighted by land, population, GDP and bank assets.

(2) Mean and distribution for this indicator are calculated across banks, not across counties.

(3) Noninterest expense less amortization of intangible assets in percent of net interest income plus noninterest income. 


\begin{tabular}{|c|c|c|c|c|c|c|c|c|c|c|c|c|}
\hline & \multirow[b]{2}{*}{ Variable } & \multicolumn{5}{|c|}{ mean (1) } & \multirow{2}{*}{ sd } & \multirow{2}{*}{$\min$} & \multirow{2}{*}{ p25 } & \multirow{2}{*}{ p50 } & \multirow{2}{*}{ p75 } & \multirow{2}{*}{$\max$} \\
\hline & & simple & land & pop. & GDP & asset & & & & & & \\
\hline \multicolumn{13}{|c|}{ Structure } \\
\hline 1 & Number of banks & 8.0 & 7.1 & 39.4 & 48.1 & 56.0 & 11.0 & 1.0 & 3.0 & 6.0 & 9.0 & 289.0 \\
\hline 2 & Number of counties a bank operates in (2) & 1.8 & n.a. & n.a. & n.a. & n.a. & 3.5 & 1.0 & 1.0 & 1.0 & 2.0 & 85.0 \\
\hline 3 & Share of the largest bank by assets (\%) & 43.3 & 45.0 & 28.7 & 27.7 & 27.0 & 20.8 & 8.2 & 28.6 & 38.2 & 52.0 & 100.0 \\
\hline 4 & Share of community banks by assets (\%) & 65.2 & 49.9 & 36.6 & 31.4 & 29.2 & 32.7 & 0.0 & 36.6 & 70.4 & 100.0 & 100.0 \\
\hline 5 & Share of top 5 US banks by assets (\%) & 0.8 & 1.7 & 5.2 & 6.7 & 12.1 & 5.5 & 0.0 & 0.0 & 0.0 & 0.0 & 100.0 \\
\hline 6 & Per capita deposits (\$ Thou.) & 10.1 & 8.4 & 12.1 & 15.5 & 23.8 & 5.1 & 0.2 & 7.0 & 9.4 & 12.2 & 98.4 \\
\hline 7 & Deposits to GDP ratio (\%) & 64.4 & 49.7 & 50.2 & 48.7 & 57.4 & 31.7 & 1.5 & 42.6 & 59.0 & 80.3 & 439.6 \\
\hline 8 & Per capita assets (\$ Thou.) & 12.6 & 10.4 & 17.6 & 27.3 & 53.5 & 8.7 & 0.2 & 8.6 & 11.6 & 15.1 & 318.0 \\
\hline 9 & Assets to GDP ratio (\%) & 78.9 & 61.2 & 68.1 & 71.0 & 96.8 & 38.5 & 2.2 & 53.6 & 72.6 & 97.2 & 538.1 \\
\hline \multicolumn{13}{|c|}{ Business model } \\
\hline 1 & Share of agricultural loans (\%) & 9.7 & 8.9 & 1.9 & 1.5 & 1.5 & 14.5 & 0.0 & 0.5 & 2.7 & 12.6 & 84.6 \\
\hline 2 & Share of commercial and industrial loans (\%) & 15.3 & 16.9 & 18.1 & 19.4 & 21.0 & 6.4 & 0.0 & 10.8 & 14.3 & 19.0 & 69.8 \\
\hline 3 & Share of commercial and industrial loans below \$1 mio (\%) & n.a. & n.a. & n.a. & n.a. & n.a. & n.a. & n.a. & n.a. & n.a. & n.a. & n.a. \\
\hline 4 & Share of real estate loans (\%) & 54.9 & 47.3 & 59.0 & 57.6 & 53.9 & 14.9 & 3.2 & 46.5 & 56.9 & 65.4 & 100.4 \\
\hline 5 & Non-interest income to asset ratio (\%) & 1.0 & 1.0 & 1.3 & 1.5 & 1.6 & 0.7 & 0.1 & 0.6 & 0.9 & 1.2 & 18.1 \\
\hline \multicolumn{13}{|c|}{ Performance } \\
\hline 1 & Common Equity Tier 1 ratio (\%) & n.a. & n.a. & n.a. & n.a. & n.a. & n.a. & n.a. & n.a. & n.a. & n.a. & n.a. \\
\hline 2 & Leverage ratio (\%) & 8.5 & 8.1 & 7.3 & 7.2 & 7.1 & 1.8 & 1.3 & 7.2 & 8.1 & 9.3 & 20.8 \\
\hline 3 & Efficiency Ratio (\%) (3) & 62.7 & 59.4 & 65.8 & 66.2 & 65.6 & 8.4 & 33.3 & 58.0 & 62.2 & 66.5 & 235.6 \\
\hline 4 & Pretax Return on Assets (\%) & 1.6 & 1.6 & 1.4 & 1.3 & 1.3 & 0.6 & -12.4 & 1.4 & 1.6 & 1.9 & 7.0 \\
\hline 5 & Net Interest Margin (\%) & 4.5 & 4.4 & 4.3 & 4.3 & 4.2 & 0.6 & 1.5 & 4.1 & 4.5 & 4.8 & 11.2 \\
\hline 6 & Non-performing assets ratio (\%) & 1.4 & 1.4 & 2.3 & 2.4 & 2.7 & 1.1 & 0.0 & 0.7 & 1.1 & 1.8 & 15.6 \\
\hline
\end{tabular}

Summary statistics: 1993

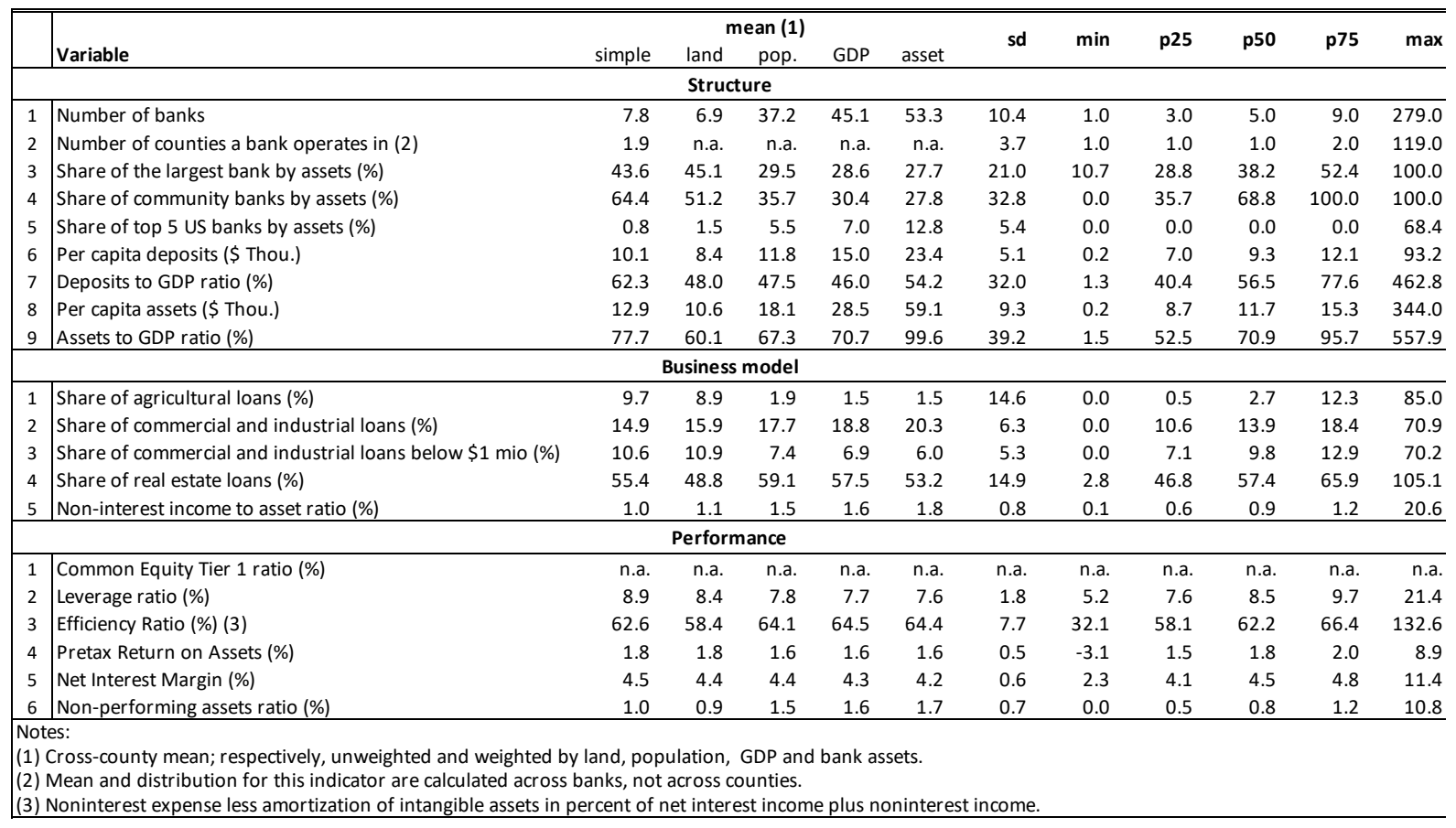




\begin{tabular}{|c|c|c|c|c|c|c|c|c|c|c|c|c|}
\hline & \multirow[b]{2}{*}{ Variable } & \multicolumn{5}{|c|}{ mean (1) } & \multirow{2}{*}{ sd } & \multirow{2}{*}{$\min$} & \multirow{2}{*}{ p25 } & \multirow{2}{*}{ p50 } & \multirow{2}{*}{ p75 } & \multirow{2}{*}{$\max$} \\
\hline & & simple & land & pop. & GDP & asset & & & & & & \\
\hline \multicolumn{13}{|c|}{ Structure } \\
\hline 1 & Number of banks & 7.7 & 6.8 & 35.4 & 42.6 & 50.6 & 9.9 & 1.0 & 3.0 & 5.0 & 9.0 & 262.0 \\
\hline 2 & Number of counties a bank operates in (2) & 1.9 & n.a. & n.a. & n.a. & n.a. & 3.8 & 1.0 & 1.0 & 1.0 & 2.0 & 132.0 \\
\hline 3 & Share of the largest bank by assets (\%) & 44.0 & 45.6 & 30.1 & 29.2 & 28.8 & 21.0 & 11.3 & 28.9 & 38.4 & 53.4 & 100.0 \\
\hline 4 & Share of community banks by assets (\%) & 62.8 & 56.9 & 33.6 & 28.6 & 25.5 & 33.1 & 0.0 & 34.2 & 67.0 & 100.0 & 100.0 \\
\hline 5 & Share of top 5 US banks by assets (\%) & 0.8 & 1.5 & 5.7 & 7.2 & 13.9 & 5.5 & 0.0 & 0.0 & 0.0 & 0.0 & 71.5 \\
\hline 6 & Per capita deposits (\$ Thou.) & 10.1 & 8.4 & 11.6 & 14.7 & 23.4 & 5.1 & 0.0 & 7.0 & 9.3 & 12.1 & 88.9 \\
\hline 7 & Deposits to GDP ratio (\%) & 59.4 & 46.3 & 45.2 & 43.7 & 51.6 & 30.7 & 0.1 & 38.9 & 54.0 & 74.5 & 483.1 \\
\hline 8 & Per capita assets (\$ Thou.) & 13.2 & 11.0 & 19.1 & 30.5 & 68.4 & 10.3 & 0.0 & 8.9 & 12.0 & 15.7 & 389.3 \\
\hline 9 & Assets to GDP ratio (\%) & 76.2 & 59.9 & 67.9 & 71.8 & 106.8 & 41.4 & 0.1 & 51.1 & 69.8 & 93.3 & 813.5 \\
\hline \multicolumn{13}{|c|}{ Business model } \\
\hline 1 & Share of agricultural loans (\%) & 9.3 & 8.5 & 1.9 & 1.5 & 1.4 & 14.2 & 0.0 & 0.5 & 2.6 & 11.6 & 84.6 \\
\hline 2 & Share of commercial and industrial loans (\%) & 15.2 & 16.2 & 18.2 & 19.4 & 20.8 & 6.5 & 0.0 & 10.6 & 14.2 & 18.8 & 69.4 \\
\hline 3 & Share of commercial and industrial loans below $\$ 1 \mathrm{mio}(\%)$ & 10.2 & 10.4 & 6.7 & 6.3 & 5.4 & 5.4 & 0.0 & 6.6 & 9.4 & 12.5 & 80.6 \\
\hline 4 & Share of real estate loans (\%) & 55.1 & 48.7 & 58.2 & 56.5 & 51.7 & 14.7 & 2.0 & 46.4 & 56.7 & 65.4 & 100.9 \\
\hline 5 & Non-interest income to asset ratio (\%) & 1.0 & 1.1 & 1.4 & 1.5 & 1.7 & 0.9 & -2.4 & 0.6 & 0.9 & 1.2 & 16.5 \\
\hline \multicolumn{13}{|c|}{ Performance } \\
\hline 1 & Common Equity Tier 1 ratio (\%) & n.a. & n.a. & n.a. & n.a. & n.a. & n.a. & n.a. & n.a. & n.a. & n.a. & n.a. \\
\hline 2 & Leverage ratio (\%) & 9.0 & 8.5 & 8.0 & 7.9 & 7.7 & 1.9 & 5.2 & 7.7 & 8.7 & 9.9 & 23.0 \\
\hline 3 & Efficiency Ratio (\%) (3) & 62.4 & 58.4 & 63.5 & 63.8 & 64.0 & 6.6 & 32.4 & 58.5 & 62.2 & 66.1 & 117.1 \\
\hline 4 & Pretax Return on Assets (\%) & 1.7 & 1.7 & 1.6 & 1.6 & 1.6 & 0.5 & -2.3 & 1.4 & 1.7 & 1.9 & 9.0 \\
\hline 5 & Net Interest Margin (\%) & 4.4 & 4.4 & 4.3 & 4.3 & 4.1 & 0.6 & 0.9 & 4.1 & 4.4 & 4.8 & 11.6 \\
\hline 6 & Non-performing assets ratio (\%) & 0.7 & 0.6 & 1.0 & 1.0 & 1.1 & 0.5 & 0.0 & 0.4 & 0.6 & 0.9 & 10.1 \\
\hline
\end{tabular}

Summary statistics: 1995

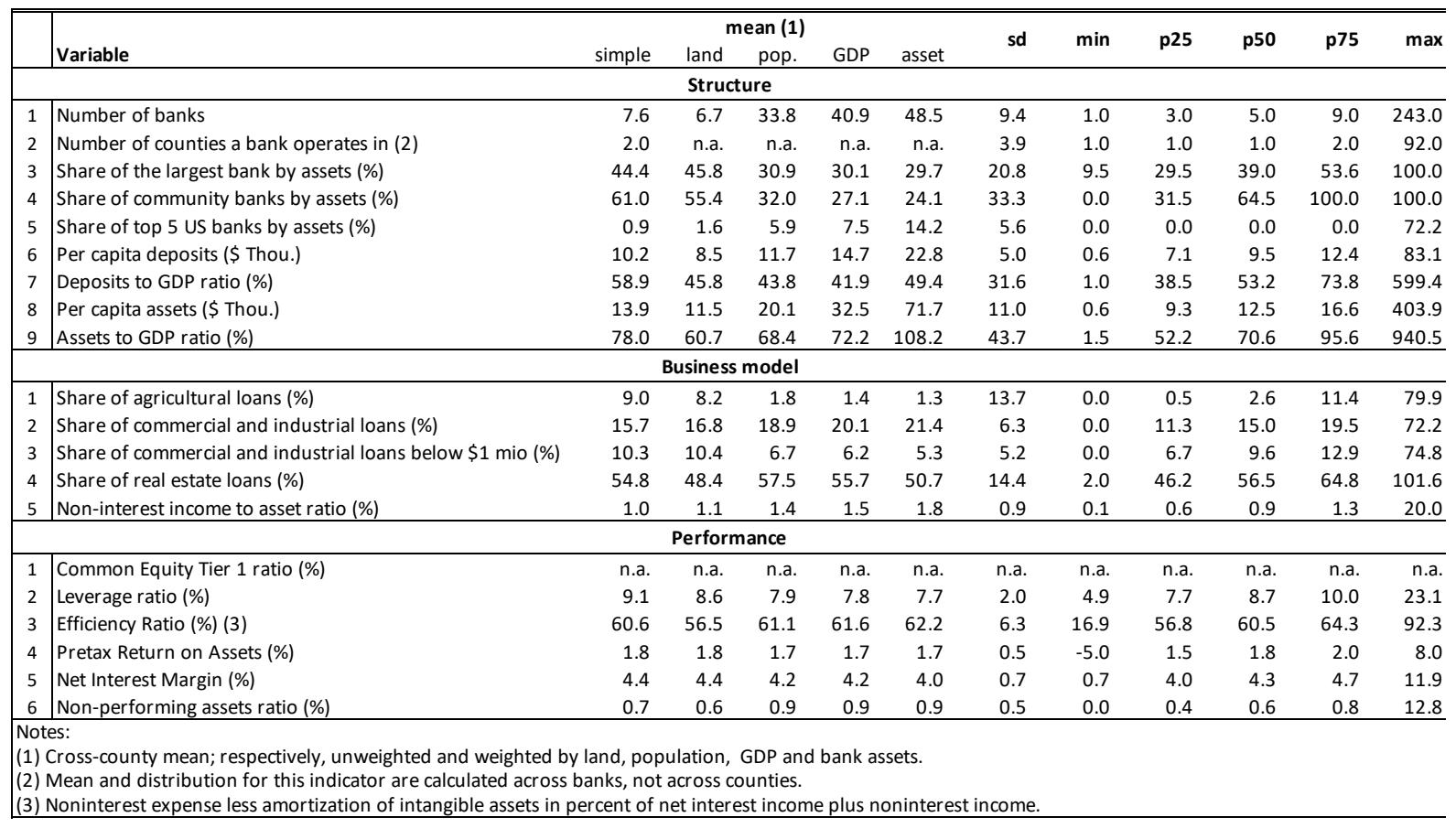




\begin{tabular}{|c|c|c|c|c|c|c|c|c|c|c|c|c|}
\hline & \multirow[b]{2}{*}{ Variable } & \multicolumn{5}{|c|}{ mean (1) } & \multirow{2}{*}{ sd } & \multirow{2}{*}{$\min$} & \multirow{2}{*}{ p25 } & \multirow{2}{*}{ p50 } & \multirow{2}{*}{ p75 } & \multirow{2}{*}{$\max$} \\
\hline & & simple & land & pop. & GDP & asset & & & & & & \\
\hline \multicolumn{13}{|c|}{ Structure } \\
\hline 1 & Number of banks & 7.5 & 6.6 & 32.0 & 38.8 & 45.7 & 8.9 & 1.0 & 3.0 & 6.0 & 9.0 & 232.0 \\
\hline 2 & Number of counties a bank operates in (2) & 2.1 & n.a. & n.a. & n.a. & n.a. & 4.4 & 1.0 & 1.0 & 1.0 & 2.0 & 153.0 \\
\hline 3 & Share of the largest bank by assets (\%) & 44.3 & 45.4 & 31.9 & 31.3 & 31.5 & 20.6 & 11.0 & 29.7 & 38.8 & 53.2 & 100.0 \\
\hline 4 & Share of community banks by assets (\%) & 61.2 & 48.5 & 31.8 & 26.7 & 23.5 & 33.6 & 0.0 & 32.0 & 64.2 & 100.0 & 100.0 \\
\hline 5 & Share of top 5 US banks by assets (\%) & 1.6 & 3.7 & 7.9 & 9.7 & 17.0 & 8.3 & 0.0 & 0.0 & 0.0 & 0.0 & 100.0 \\
\hline 6 & Per capita deposits (\$ Thou.) & 10.5 & 8.7 & 11.8 & 14.8 & 22.7 & 5.3 & 0.1 & 7.3 & 9.7 & 12.7 & 75.1 \\
\hline 7 & Deposits to GDP ratio (\%) & 56.9 & 44.3 & 42.1 & 40.2 & 46.8 & 29.8 & 0.8 & 37.5 & 51.7 & 71.0 & 536.5 \\
\hline 8 & Per capita assets (\$ Thou.) & 14.3 & 11.8 & 20.9 & 35.3 & 82.2 & 12.1 & 0.1 & 9.7 & 12.8 & 16.9 & 451.5 \\
\hline 9 & Assets to GDP ratio (\%) & 75.1 & 58.8 & 67.0 & 71.4 & 110.1 & 41.6 & 0.9 & 50.7 & 68.3 & 90.9 & 720.7 \\
\hline \multicolumn{13}{|c|}{ Business model } \\
\hline 1 & Share of agricultural loans (\%) & 8.5 & 7.9 & 1.7 & 1.4 & 1.3 & 13.1 & 0.0 & 0.5 & 2.4 & 10.6 & 75.4 \\
\hline 2 & Share of commercial and industrial loans (\%) & 15.8 & 16.7 & 19.2 & 20.5 & 21.5 & 6.0 & 0.9 & 11.7 & 15.2 & 19.2 & 50.0 \\
\hline 3 & Share of commercial and industrial loans below $\$ 1 \mathrm{mio}(\%)$ & 10.4 & 10.6 & 6.8 & 6.3 & 5.4 & 7.5 & 0.2 & 6.7 & 9.5 & 12.8 & 312.2 \\
\hline 4 & Share of real estate loans (\%) & 55.3 & 48.7 & 56.5 & 54.5 & 49.3 & 14.0 & 1.1 & 47.4 & 57.3 & 65.0 & 105.9 \\
\hline 5 & Non-interest income to asset ratio (\%) & 1.1 & 1.2 & 1.5 & 1.6 & 1.9 & 1.1 & 0.1 & 0.7 & 1.0 & 1.3 & 34.0 \\
\hline \multicolumn{13}{|c|}{ Performance } \\
\hline 1 & Common Equity Tier 1 ratio (\%) & n.a. & n.a. & n.a. & n.a. & n.a. & n.a. & n.a. & n.a. & n.a. & n.a. & n.a. \\
\hline 2 & Leverage ratio $(\%)$ & 9.1 & 8.5 & 7.9 & 7.8 & 7.7 & 1.9 & 5.3 & 7.7 & 8.7 & 10.0 & 25.0 \\
\hline 3 & Efficiency Ratio (\%) (3) & 60.5 & 56.6 & 61.8 & 62.1 & 62.6 & 7.2 & 18.6 & 56.5 & 60.1 & 64.3 & 195.8 \\
\hline 4 & Pretax Return on Assets (\%) & 1.8 & 1.8 & 1.7 & 1.7 & 1.7 & 0.5 & -5.6 & 1.5 & 1.8 & 2.0 & 9.3 \\
\hline 5 & Net Interest Margin (\%) & 4.4 & 4.4 & 4.3 & 4.2 & 4.1 & 0.6 & 2.4 & 4.0 & 4.4 & 4.7 & 11.9 \\
\hline 6 & Non-performing assets ratio (\%) & 0.7 & 0.6 & 0.8 & 0.8 & 0.8 & 0.5 & 0.0 & 0.4 & 0.6 & 0.8 & 9.2 \\
\hline
\end{tabular}

Summary statistics: 1997

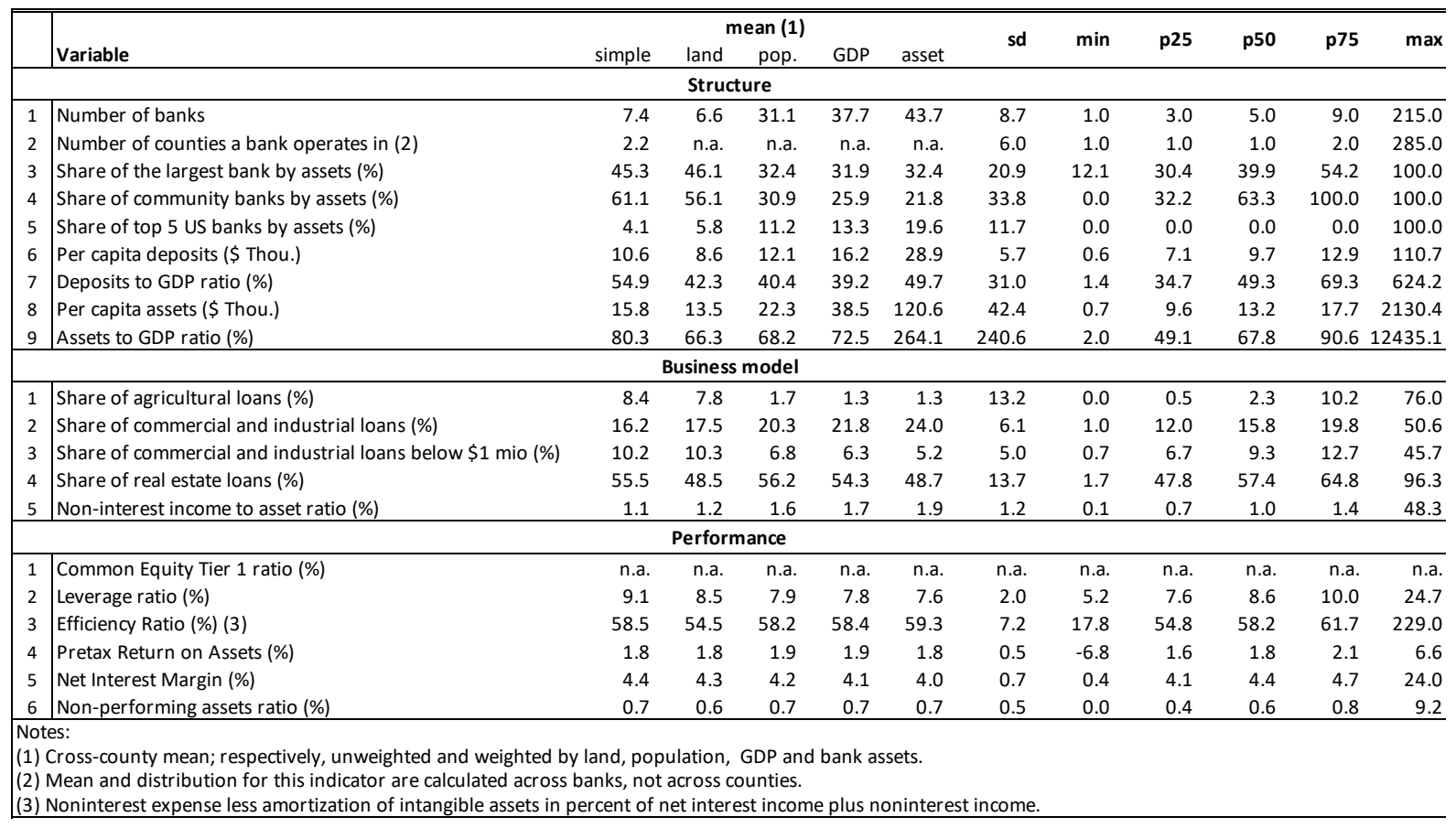




\begin{tabular}{|c|c|c|c|c|c|c|c|c|c|c|c|c|}
\hline & \multirow[b]{2}{*}{ Variable } & \multicolumn{5}{|c|}{ mean (1) } & \multirow{2}{*}{ sd } & \multirow{2}{*}{$\min$} & \multirow{2}{*}{ p25 } & \multirow{2}{*}{ p50 } & \multirow{2}{*}{ p75 } & \multirow{2}{*}{$\max$} \\
\hline & & simple & land & pop. & GDP & asset & & & & & & \\
\hline \multicolumn{13}{|c|}{ Structure } \\
\hline 1 & Number of banks & 7.5 & 6.7 & 30.9 & 37.7 & 43.2 & 8.6 & 1.0 & 3.0 & 6.0 & 9.0 & 212.0 \\
\hline 2 & Number of counties a bank operates in (2) & 2.3 & n.a. & n.a. & n.a. & n.a. & 7.9 & 1.0 & 1.0 & 1.0 & 2.0 & 380.0 \\
\hline 3 & Share of the largest bank by assets (\%) & 45.1 & 45.7 & 32.5 & 32.0 & 32.5 & 20.6 & 12.4 & 30.0 & 39.7 & 54.1 & 100.0 \\
\hline 4 & Share of community banks by assets (\%) & 58.2 & 54.1 & 28.2 & 23.3 & 19.9 & 34.0 & 0.0 & 28.6 & 58.0 & 99.0 & 100.0 \\
\hline 5 & Share of top 5 US banks by assets (\%) & 6.2 & 6.7 & 16.0 & 18.1 & 21.2 & 14.0 & 0.0 & 0.0 & 0.0 & 0.0 & 100.0 \\
\hline 6 & Per capita deposits (\$ Thou.) & 11.1 & 9.1 & 12.6 & 17.2 & 29.7 & 6.6 & 0.6 & 7.4 & 10.0 & 13.3 & 119.4 \\
\hline 7 & Deposits to GDP ratio (\%) & 54.4 & 42.3 & 39.5 & 38.4 & 48.9 & 32.6 & 1.2 & 34.3 & 48.1 & 68.6 & 620.0 \\
\hline 8 & Per capita assets (\$ Thou.) & 17.6 & 13.7 & 23.9 & 40.7 & 108.2 & 85.9 & 0.7 & 10.5 & 14.1 & 19.0 & 4739.9 \\
\hline 9 & Assets to GDP ratio (\%) & 86.4 & 63.7 & 68.4 & 72.8 & 217.7 & 545.4 & 1.6 & 49.9 & 69.5 & 93.4 & 30128.5 \\
\hline \multicolumn{13}{|c|}{ Business model } \\
\hline 1 & Share of agricultural loans (\%) & 8.0 & 7.5 & 1.6 & 1.3 & 1.2 & 12.6 & 0.0 & 0.5 & 2.1 & 9.2 & 72.0 \\
\hline 2 & Share of commercial and industrial loans (\%) & 17.2 & 18.2 & 21.6 & 23.1 & 24.6 & 6.3 & 0.4 & 12.8 & 16.8 & 21.1 & 58.4 \\
\hline 3 & Share of commercial and industrial loans below $\$ 1 \mathrm{mio}(\%)$ & 10.1 & 10.3 & 6.7 & 6.2 & 5.3 & 5.5 & 0.2 & 6.6 & 9.2 & 12.7 & 122.5 \\
\hline 4 & Share of real estate loans (\%) & 55.4 & 48.3 & 55.1 & 53.0 & 48.3 & 13.4 & 1.5 & 48.0 & 57.1 & 64.4 & 98.7 \\
\hline 5 & Non-interest income to asset ratio (\%) & 1.3 & 1.3 & 1.8 & 1.9 & 2.2 & 1.4 & 0.0 & 0.7 & 1.1 & 1.5 & 44.5 \\
\hline \multicolumn{13}{|c|}{ Performance } \\
\hline 1 & Common Equity Tier 1 ratio (\%) & n.a. & n.a. & n.a. & n.a. & n.a. & n.a. & n.a. & n.a. & n.a. & n.a. & n.a. \\
\hline 2 & Leverage ratio $(\%)$ & 9.0 & 8.4 & 7.8 & 7.7 & 7.6 & 2.2 & 5.4 & 7.6 & 8.5 & 9.8 & 61.8 \\
\hline 3 & Efficiency Ratio (\%) (3) & 60.3 & 56.3 & 60.5 & 60.8 & 61.8 & 8.6 & 13.7 & 56.2 & 59.9 & 63.6 & 343.3 \\
\hline 4 & Pretax Return on Assets (\%) & 1.8 & 1.8 & 1.8 & 1.8 & 1.8 & 0.5 & -3.4 & 1.5 & 1.8 & 2.0 & 10.1 \\
\hline 5 & Net Interest Margin (\%) & 4.3 & 4.3 & 4.1 & 4.0 & 3.9 & 0.8 & -0.2 & 4.0 & 4.2 & 4.6 & 33.5 \\
\hline 6 & Non-performing assets ratio (\%) & 0.7 & 0.6 & 0.6 & 0.6 & 0.7 & 0.5 & 0.0 & 0.4 & 0.6 & 0.8 & 7.7 \\
\hline
\end{tabular}

Summary statistics: 1999

\begin{tabular}{|c|c|c|c|c|c|c|c|c|c|c|c|c|}
\hline & \multirow[b]{2}{*}{ Variable } & \multicolumn{5}{|c|}{ mean (1) } & \multirow{2}{*}{ sd } & \multirow{2}{*}{$\min$} & \multirow{2}{*}{ p25 } & \multirow{2}{*}{ p50 } & \multirow{2}{*}{ p75 } & \multirow{2}{*}{$\max$} \\
\hline & & simple & land & pop. & GDP & asset & & & & & & \\
\hline \multicolumn{13}{|c|}{ Structure } \\
\hline 1 & Number of banks & 7.7 & 6.9 & 31.4 & 38.4 & 46.0 & 8.8 & 1.0 & 3.0 & 6.0 & 9.0 & 206.0 \\
\hline 2 & Number of counties a bank operates in (2) & 2.4 & n.a. & n.a. & n.a. & n.a. & 7.5 & 1.0 & 1.0 & 1.0 & 2.0 & 276.0 \\
\hline 3 & Share of the largest bank by assets (\%) & 45.0 & 46.5 & 34.5 & 34.3 & 35.1 & 20.5 & 11.5 & 30.1 & 40.0 & 53.5 & 100.0 \\
\hline 4 & Share of community banks by assets (\%) & 59.1 & 54.4 & 28.5 & 23.5 & 19.5 & 33.7 & 0.0 & 29.6 & 61.4 & 95.9 & 100.0 \\
\hline 5 & Share of top 5 US banks by assets (\%) & 3.8 & 6.3 & 13.8 & 16.7 & 23.5 & 11.6 & 0.0 & 0.0 & 0.0 & 0.0 & 100.0 \\
\hline 6 & Per capita deposits (\$ Thou.) & 11.3 & 9.4 & 12.8 & 17.3 & 29.2 & 6.6 & 0.8 & 7.6 & 10.3 & 13.6 & 114.0 \\
\hline 7 & Deposits to GDP ratio (\%) & 54.0 & 42.0 & 38.8 & 37.4 & 47.8 & 31.5 & 1.4 & 34.0 & 48.0 & 68.1 & 495.2 \\
\hline 8 & Per capita assets (\$ Thou.) & 17.1 & 14.2 & 24.9 & 42.5 & 95.8 & 38.4 & 0.9 & 10.5 & 14.3 & 19.1 & 1511.4 \\
\hline 9 & Assets to GDP ratio (\%) & 79.9 & 62.6 & 68.7 & 73.1 & 134.6 & 192.6 & 2.0 & 48.9 & 67.8 & 91.0 & 7179.5 \\
\hline \multicolumn{13}{|c|}{ Business model } \\
\hline 1 & Share of agricultural loans (\%) & 7.4 & 6.9 & 1.5 & 1.2 & 1.1 & 11.9 & 0.0 & 0.5 & 1.9 & 8.6 & 73.6 \\
\hline 2 & Share of commercial and industrial loans (\%) & 17.2 & 18.6 & 21.6 & 23.1 & 24.3 & 6.4 & 0.5 & 12.8 & 16.7 & 21.0 & 61.9 \\
\hline 3 & Share of commercial and industrial loans below $\$ 1$ mio (\%) & 10.2 & 10.3 & 6.9 & 6.4 & 5.6 & 5.3 & 0.4 & 6.7 & 9.3 & 12.6 & 90.4 \\
\hline 4 & Share of real estate loans (\%) & 56.9 & 49.6 & 56.7 & 54.7 & 49.7 & 13.3 & 3.0 & 49.8 & 58.8 & 65.7 & 98.4 \\
\hline 5 & Non-interest income to asset ratio (\%) & 1.3 & 1.3 & 1.8 & 2.0 & 2.4 & 1.5 & 0.1 & 0.7 & 1.1 & 1.5 & 46.7 \\
\hline \multicolumn{13}{|c|}{ Performance } \\
\hline 1 & Common Equity Tier 1 ratio (\%) & n.a. & n.a. & n.a. & n.a. & n.a. & n.a. & n.a. & n.a. & n.a. & n.a. & n.a. \\
\hline 2 & Leverage ratio (\%) & 9.0 & 8.4 & 8.0 & 7.9 & 7.9 & 1.9 & 5.5 & 7.7 & 8.6 & 9.8 & 27.2 \\
\hline 3 & Efficiency Ratio (\%) (3) & 59.5 & 55.0 & 58.0 & 58.0 & 58.1 & 6.9 & 25.6 & 55.3 & 59.1 & 63.1 & 125.8 \\
\hline 4 & Pretax Return on Assets (\%) & 1.8 & 1.8 & 1.9 & 1.9 & 2.0 & 0.5 & -2.3 & 1.5 & 1.8 & 2.0 & 10.2 \\
\hline 5 & Net Interest Margin (\%) & 4.3 & 4.2 & 4.0 & 4.0 & 3.9 & 0.7 & 1.4 & 3.9 & 4.2 & 4.5 & 20.0 \\
\hline 6 & Non-performing assets ratio (\%) & 0.6 & 0.6 & 0.6 & 0.6 & 0.6 & 0.5 & 0.0 & 0.4 & 0.5 & 0.7 & 11.8 \\
\hline
\end{tabular}




\begin{tabular}{|c|c|c|c|c|c|c|c|c|c|c|c|c|}
\hline & \multirow[b]{2}{*}{ Variable } & \multicolumn{5}{|c|}{ mean (1) } & \multirow{2}{*}{ sd } & \multirow{2}{*}{$\min$} & \multirow{2}{*}{ p25 } & \multirow{2}{*}{ p50 } & \multirow{2}{*}{ p75 } & \multirow{2}{*}{$\max$} \\
\hline & & simple & land & pop. & GDP & asset & & & & & & \\
\hline \multicolumn{13}{|c|}{ Structure } \\
\hline 1 & Number of banks & 7.7 & 7.4 & 31.5 & 38.5 & 44.2 & 8.8 & 1.0 & 3.0 & 6.0 & 9.0 & 209.0 \\
\hline 2 & Number of counties a bank operates in (2) & 2.5 & n.a. & n.a. & n.a. & n.a. & 9.9 & 1.0 & 1.0 & 1.0 & 2.0 & 580.0 \\
\hline 3 & Share of the largest bank by assets (\%) & 44.9 & 48.7 & 31.5 & 31.1 & 33.0 & 21.3 & 11.9 & 29.2 & 39.4 & 54.2 & 100.0 \\
\hline 4 & Share of community banks by assets (\%) & 56.2 & 50.8 & 27.2 & 22.2 & 18.5 & 34.3 & 0.0 & 26.2 & 55.6 & 93.0 & 100.0 \\
\hline 5 & Share of top 5 US banks by assets (\%) & 5.2 & 6.1 & 14.9 & 17.7 & 23.6 & 12.3 & 0.0 & 0.0 & 0.0 & 0.0 & 100.0 \\
\hline 6 & Per capita deposits (\$ Thou.) & 11.6 & 10.1 & 13.7 & 18.8 & 32.7 & 7.8 & 0.8 & 7.8 & 10.4 & 13.8 & 201.9 \\
\hline 7 & Deposits to GDP ratio (\%) & 53.0 & 43.8 & 39.3 & 38.1 & 50.6 & 33.2 & 1.4 & 34.0 & 47.1 & 66.2 & 861.5 \\
\hline 8 & Per capita assets (\$ Thou.) & 17.2 & 15.0 & 26.2 & 46.9 & 106.3 & 17.9 & 1.1 & 11.1 & 14.9 & 19.8 & 579.7 \\
\hline 9 & Assets to GDP ratio (\%) & 76.4 & 63.9 & 68.2 & 73.2 & 116.6 & 61.7 & 2.2 & 50.0 & 67.9 & 92.4 & 1728.1 \\
\hline \multicolumn{13}{|c|}{ Business model } \\
\hline 1 & Share of agricultural loans (\%) & 6.8 & 7.0 & 1.4 & 1.2 & 1.0 & 11.3 & 0.0 & 0.5 & 1.7 & 7.4 & 72.4 \\
\hline 2 & Share of commercial and industrial loans (\%) & 18.1 & 19.8 & 21.7 & 22.9 & 24.3 & 6.5 & 0.0 & 13.5 & 17.8 & 22.2 & 43.7 \\
\hline 3 & Share of commercial and industrial loans below $\$ 1 \mathrm{mio}(\%)$ & 10.1 & 10.9 & 6.5 & 5.9 & 5.1 & 4.9 & 0.0 & 6.8 & 9.3 & 12.4 & 49.8 \\
\hline 4 & Share of real estate loans (\%) & 56.9 & 54.1 & 57.4 & 55.5 & 49.6 & 13.1 & 3.8 & 50.1 & 58.6 & 65.5 & 97.9 \\
\hline 5 & Non-interest income to asset ratio (\%) & 1.3 & 1.3 & 1.8 & 1.9 & 2.4 & 1.4 & 0.1 & 0.8 & 1.1 & 1.5 & 46.3 \\
\hline \multicolumn{13}{|c|}{ Performance } \\
\hline 1 & Common Equity Tier 1 ratio (\%) & n.a. & n.a. & n.a. & n.a. & n.a. & n.a. & n.a. & n.a. & n.a. & n.a. & n.a. \\
\hline 2 & Leverage ratio $(\%)$ & 8.8 & 8.9 & 7.8 & 7.7 & 7.7 & 1.9 & 5.3 & 7.6 & 8.3 & 9.6 & 29.3 \\
\hline 3 & Efficiency Ratio (\%) (3) & 59.7 & 58.9 & 58.2 & 58.0 & 58.4 & 6.9 & 25.8 & 55.4 & 59.4 & 63.6 & 113.5 \\
\hline 4 & Pretax Return on Assets (\%) & 1.6 & 1.6 & 1.7 & 1.7 & 1.8 & 0.6 & -6.9 & 1.3 & 1.6 & 1.8 & 14.6 \\
\hline 5 & Net Interest Margin (\%) & 4.2 & 4.3 & 3.9 & 3.9 & 3.8 & 0.8 & 1.6 & 3.8 & 4.1 & 4.5 & 19.9 \\
\hline 6 & Non-performing assets ratio (\%) & 0.7 & 0.7 & 0.7 & 0.7 & 0.7 & 0.5 & 0.0 & 0.5 & 0.6 & 0.8 & 12.2 \\
\hline
\end{tabular}

Summary statistics: 2001

\begin{tabular}{|c|c|c|c|c|c|c|c|c|c|c|c|c|}
\hline & \multirow[b]{2}{*}{ Variable } & \multicolumn{5}{|c|}{ mean (1) } & \multirow{2}{*}{ sd } & \multirow{2}{*}{$\min$} & \multirow{2}{*}{ p25 } & \multirow{2}{*}{ p50 } & \multirow{2}{*}{ p75 } & \multirow{2}{*}{$\max$} \\
\hline & & simple & land & pop. & GDP & asset & & & & & & \\
\hline \multicolumn{13}{|c|}{ Structure } \\
\hline 1 & Number of banks & 7.8 & 6.9 & 31.6 & 38.5 & 43.8 & 8.9 & 1.0 & 3.0 & 6.0 & 9.0 & 206.0 \\
\hline 2 & Number of counties a bank operates in (2) & 2.6 & n.a. & n.a. & n.a. & n.a. & 10.1 & 1.0 & 1.0 & 1.0 & 2.0 & 573.0 \\
\hline 3 & Share of the largest bank by assets (\%) & 44.6 & 45.2 & 31.9 & 32.0 & 34.6 & 20.7 & 8.7 & 29.5 & 39.5 & 54.2 & 100.0 \\
\hline 4 & Share of community banks by assets (\%) & 55.7 & 47.7 & 27.1 & 22.5 & 19.0 & 33.5 & 0.0 & 26.1 & 55.3 & 89.3 & 100.0 \\
\hline 5 & Share of top 5 US banks by assets (\%) & 5.0 & 6.4 & 17.8 & 21.0 & 25.2 & 12.2 & 0.0 & 0.0 & 0.0 & 0.0 & 100.0 \\
\hline 6 & Per capita deposits (\$ Thou.) & 12.3 & 10.0 & 14.5 & 20.1 & 33.6 & 8.3 & 0.7 & 8.2 & 11.1 & 14.7 & 244.2 \\
\hline 7 & Deposits to GDP ratio (\%) & 53.3 & 40.6 & 40.0 & 39.3 & 51.1 & 30.7 & 1.7 & 34.1 & 47.9 & 66.8 & 738.0 \\
\hline 8 & Per capita assets (\$ Thou.) & 18.0 & 14.5 & 27.2 & 46.9 & 94.3 & 16.5 & 0.8 & 11.5 & 15.8 & 21.1 & 526.9 \\
\hline 9 & Assets to GDP ratio (\%) & 75.6 & 57.8 & 69.3 & 74.1 & 108.7 & 44.0 & 2.4 & 50.0 & 68.7 & 92.6 & 955.3 \\
\hline \multicolumn{13}{|c|}{ Business model } \\
\hline 1 & Share of agricultural loans (\%) & 6.6 & 6.3 & 1.4 & 1.1 & 1.0 & 10.9 & 0.0 & 0.5 & 1.6 & 7.0 & 72.2 \\
\hline 2 & Share of commercial and industrial loans (\%) & 17.4 & 17.4 & 20.3 & 21.4 & 22.4 & 6.1 & 0.6 & 13.2 & 17.1 & 21.3 & 50.9 \\
\hline 3 & Share of commercial and industrial loans below $\$ 1$ mio (\%) & 10.0 & 10.2 & 6.5 & 5.9 & 5.3 & 5.0 & 0.0 & 6.8 & 9.4 & 12.4 & 48.8 \\
\hline 4 & Share of real estate loans (\%) & 58.3 & 52.5 & 58.6 & 56.7 & 51.7 & 12.9 & 3.5 & 51.9 & 59.9 & 67.0 & 90.6 \\
\hline 5 & Non-interest income to asset ratio (\%) & 1.3 & 1.2 & 1.8 & 1.9 & 2.2 & 1.1 & 0.1 & 0.8 & 1.1 & 1.5 & 39.6 \\
\hline \multicolumn{13}{|c|}{ Performance } \\
\hline 1 & Common Equity Tier 1 ratio (\%) & n.a. & n.a. & n.a. & n.a. & n.a. & n.a. & n.a. & n.a. & n.a. & n.a. & n.a. \\
\hline 2 & Leverage ratio (\%) & 8.7 & 8.4 & 7.9 & 7.8 & 7.8 & 1.8 & 5.2 & 7.6 & 8.3 & 9.4 & 29.6 \\
\hline 3 & Efficiency Ratio (\%) (3) & 60.5 & 57.1 & 58.7 & 58.6 & 58.6 & 7.1 & 34.2 & 56.1 & 60.1 & 64.4 & 130.3 \\
\hline 4 & Pretax Return on Assets (\%) & 1.6 & 1.5 & 1.7 & 1.7 & 1.7 & 0.5 & -4.4 & 1.3 & 1.6 & 1.8 & 7.9 \\
\hline 5 & Net Interest Margin (\%) & 4.1 & 4.0 & 3.9 & 3.9 & 3.8 & 0.7 & 1.4 & 3.7 & 4.0 & 4.3 & 19.8 \\
\hline 6 & Non-performing assets ratio (\%) & 0.8 & 0.8 & 0.8 & 0.8 & 0.9 & 0.5 & 0.0 & 0.6 & 0.8 & 1.0 & 7.1 \\
\hline
\end{tabular}




\begin{tabular}{|c|c|c|c|c|c|c|c|c|c|c|c|c|}
\hline & \multirow[b]{2}{*}{ Variable } & \multicolumn{5}{|c|}{ mean (1) } & \multirow{2}{*}{ sd } & \multirow{2}{*}{$\min$} & \multirow{2}{*}{ p25 } & \multirow{2}{*}{ p50 } & \multirow{2}{*}{ p75 } & \multirow{2}{*}{$\max$} \\
\hline & & simple & land & pop. & GDP & asset & & & & & & \\
\hline \multicolumn{13}{|c|}{ Structure } \\
\hline 1 & Number of banks & 7.9 & 7.1 & 31.5 & 38.1 & 42.8 & 8.8 & 1.0 & 3.0 & 6.0 & 10.0 & 200.0 \\
\hline 2 & Number of counties a bank operates in (2) & 2.7 & n.a. & n.a. & n.a. & n.a. & 11.4 & 1.0 & 1.0 & 1.0 & 2.0 & 572.0 \\
\hline 3 & Share of the largest bank by assets (\%) & 43.9 & 44.5 & 31.3 & 31.5 & 34.3 & 20.6 & 9.7 & 28.9 & 38.6 & 53.2 & 100.0 \\
\hline 4 & Share of community banks by assets (\%) & 56.1 & 46.9 & 27.0 & 22.5 & 18.5 & 33.5 & 0.0 & 27.2 & 54.9 & 89.4 & 100.0 \\
\hline 5 & Share of top 5 US banks by assets (\%) & 5.8 & 6.2 & 19.0 & 22.1 & 26.8 & 13.3 & 0.0 & 0.0 & 0.0 & 0.0 & 100.0 \\
\hline 6 & Per capita deposits (\$ Thou.) & 12.9 & 10.7 & 15.6 & 21.7 & 37.9 & 8.6 & 1.0 & 8.7 & 11.6 & 15.3 & 222.2 \\
\hline 7 & Deposits to GDP ratio (\%) & 53.6 & 41.7 & 41.3 & 41.2 & 53.6 & 29.4 & 1.2 & 35.4 & 48.4 & 66.4 & 652.9 \\
\hline 8 & Per capita assets (\$ Thou.) & 18.7 & 15.3 & 28.8 & 49.2 & 105.4 & 18.0 & 1.2 & 12.2 & 16.4 & 21.7 & 580.4 \\
\hline 9 & Assets to GDP ratio (\%) & 75.5 & 58.9 & 70.7 & 76.5 & 116.5 & 42.7 & 1.9 & 51.5 & 68.8 & 91.8 & 791.6 \\
\hline \multicolumn{13}{|c|}{ Business model } \\
\hline 1 & Share of agricultural loans (\%) & 6.3 & 6.0 & 1.3 & 1.0 & 0.9 & 10.5 & 0.0 & 0.4 & 1.5 & 6.8 & 70.8 \\
\hline 2 & Share of commercial and industrial loans (\%) & 16.5 & 16.6 & 18.5 & 19.2 & 19.9 & 5.9 & 0.9 & 12.7 & 16.0 & 19.7 & 54.6 \\
\hline 3 & Share of commercial and industrial loans below $\$ 1 \mathrm{mio}(\%)$ & 9.6 & 9.6 & 6.4 & 5.8 & 5.2 & 8.4 & 0.0 & 6.3 & 8.7 & 11.7 & 393.1 \\
\hline 4 & Share of real estate loans (\%) & 60.0 & 53.6 & 60.7 & 59.1 & 53.8 & 13.1 & 1.7 & 53.7 & 62.1 & 68.6 & 95.4 \\
\hline 5 & Non-interest income to asset ratio (\%) & 1.3 & 1.3 & 1.8 & 1.9 & 2.3 & 1.2 & 0.1 & 0.9 & 1.2 & 1.5 & 38.1 \\
\hline \multicolumn{13}{|c|}{ Performance } \\
\hline 1 & Common Equity Tier 1 ratio (\%) & n.a. & n.a. & n.a. & n.a. & n.a. & n.a. & n.a. & n.a. & n.a. & n.a. & n.a. \\
\hline 2 & Leverage ratio $(\%)$ & 8.7 & 8.3 & 7.9 & 7.8 & 7.9 & 1.9 & 5.3 & 7.5 & 8.3 & 9.4 & 29.0 \\
\hline 3 & Efficiency Ratio (\%) (3) & 59.7 & 56.3 & 57.8 & 57.8 & 57.8 & 7.3 & 29.6 & 55.4 & 58.8 & 63.2 & 121.2 \\
\hline 4 & Pretax Return on Assets (\%) & 1.7 & 1.7 & 1.9 & 1.9 & 2.0 & 0.6 & -8.0 & 1.5 & 1.7 & 2.0 & 16.6 \\
\hline 5 & Net Interest Margin (\%) & 4.2 & 4.1 & 4.0 & 4.0 & 4.0 & 0.6 & 1.3 & 3.9 & 4.2 & 4.5 & 17.6 \\
\hline 6 & Non-performing assets ratio (\%) & 0.9 & 0.8 & 0.8 & 0.8 & 0.9 & 0.5 & 0.0 & 0.6 & 0.8 & 1.0 & 11.1 \\
\hline
\end{tabular}

Summary statistics: 2003

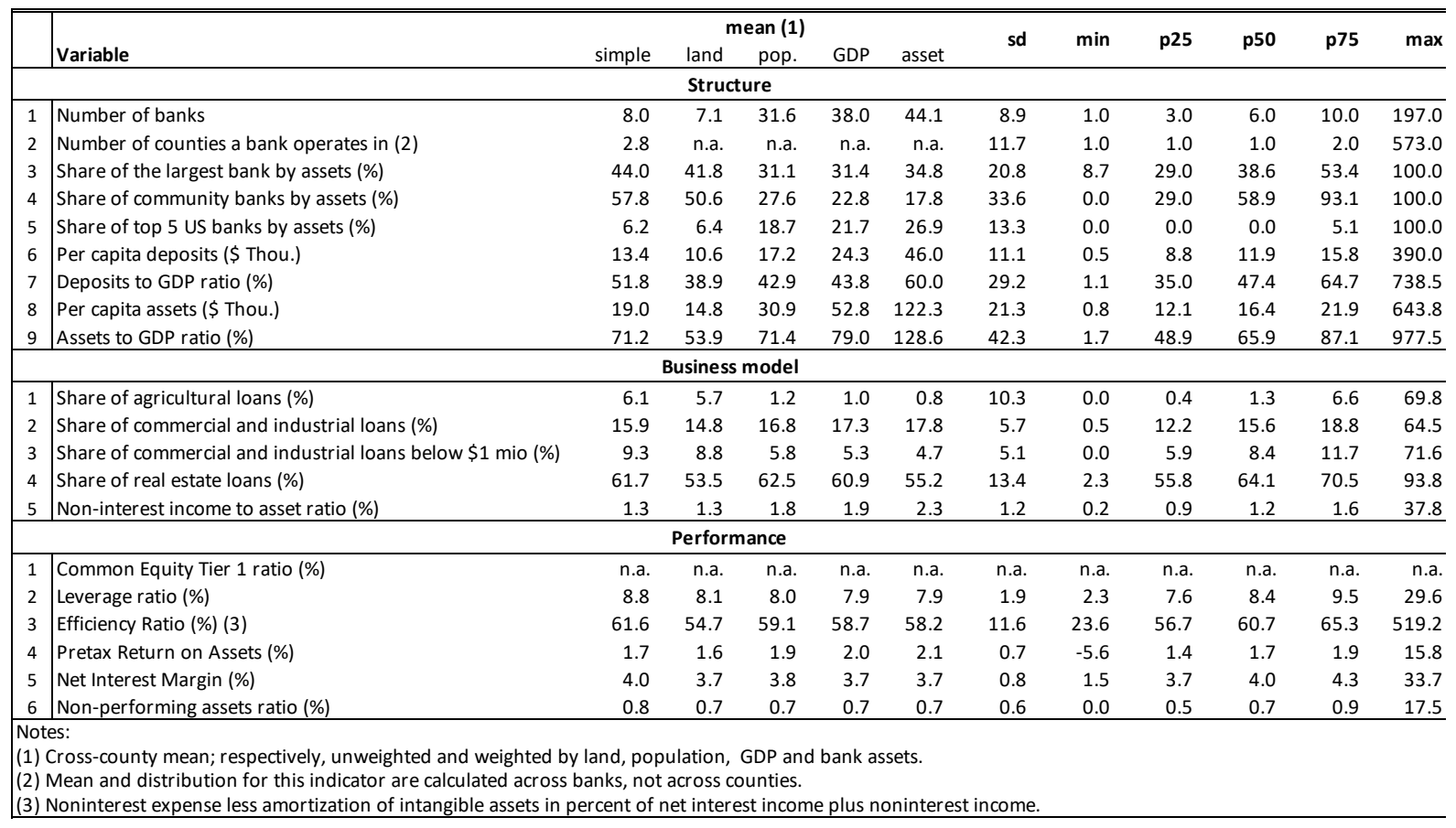




\begin{tabular}{|c|c|c|c|c|c|c|c|c|c|c|c|c|}
\hline & \multirow[b]{2}{*}{ Variable } & \multicolumn{5}{|c|}{ mean (1) } & \multirow{2}{*}{ sd } & \multirow{2}{*}{$\min$} & \multirow{2}{*}{ p25 } & \multirow{2}{*}{ p50 } & \multirow{2}{*}{ p75 } & \multirow{2}{*}{$\max$} \\
\hline & & simple & land & pop. & GDP & asset & & & & & & \\
\hline \multicolumn{13}{|c|}{ Structure } \\
\hline 1 & Number of banks & 8.0 & 7.2 & 31.4 & 37.7 & 43.4 & 8.8 & 1.0 & 3.0 & 6.0 & 10.0 & 195.0 \\
\hline 2 & Number of counties a bank operates in (2) & 2.9 & n.a. & n.a. & n.a. & n.a. & 13.1 & 1.0 & 1.0 & 1.0 & 2.0 & 583.0 \\
\hline 3 & Share of the largest bank by assets (\%) & 44.0 & 44.9 & 31.8 & 32.1 & 35.7 & 20.7 & 9.8 & 28.9 & 38.7 & 53.3 & 100.0 \\
\hline 4 & Share of community banks by assets (\%) & 56.8 & 47.4 & 26.4 & 22.0 & 16.1 & 33.8 & 0.0 & 27.3 & 57.8 & 91.1 & 100.0 \\
\hline 5 & Share of top 5 US banks by assets (\%) & 9.3 & 20.1 & 21.3 & 24.4 & 32.0 & 17.0 & 0.0 & 0.0 & 0.0 & 14.5 & 100.0 \\
\hline 6 & Per capita deposits (\$ Thou.) & 13.7 & 11.3 & 17.6 & 25.2 & 56.1 & 11.4 & 0.4 & 9.0 & 12.1 & 16.1 & 297.9 \\
\hline 7 & Deposits to GDP ratio (\%) & 49.7 & 38.4 & 41.4 & 42.5 & 65.7 & 28.6 & 0.7 & 33.2 & 45.6 & 61.4 & 601.2 \\
\hline 8 & Per capita assets (\$ Thou.) & 19.9 & 16.3 & 33.6 & 61.1 & 177.6 & 26.3 & 0.5 & 12.4 & 17.0 & 22.5 & 848.9 \\
\hline 9 & Assets to GDP ratio (\%) & 69.7 & 54.2 & 71.7 & 81.3 & 160.2 & 46.0 & 1.0 & 47.9 & 64.5 & 83.8 & 1274.2 \\
\hline \multicolumn{13}{|c|}{ Business model } \\
\hline 1 & Share of agricultural loans (\%) & 6.0 & 5.6 & 1.2 & 1.0 & 0.8 & 10.2 & 0.0 & 0.4 & 1.3 & 6.4 & 71.1 \\
\hline 2 & Share of commercial and industrial loans (\%) & 15.6 & 14.8 & 16.1 & 16.4 & 16.8 & 5.8 & 0.8 & 12.2 & 15.0 & 18.1 & 67.1 \\
\hline 3 & Share of commercial and industrial loans below $\$ 1 \mathrm{mio}(\%)$ & 8.7 & 8.0 & 5.5 & 5.0 & 4.3 & 4.8 & 0.0 & 5.5 & 7.9 & 11.0 & 52.3 \\
\hline 4 & Share of real estate loans (\%) & 64.2 & 59.6 & 65.3 & 63.8 & 56.9 & 12.6 & 2.7 & 58.9 & 66.6 & 72.3 & 95.8 \\
\hline 5 & Non-interest income to asset ratio (\%) & 1.3 & 1.4 & 1.6 & 1.7 & 2.2 & 1.2 & 0.2 & 0.8 & 1.2 & 1.5 & 36.3 \\
\hline \multicolumn{13}{|c|}{ Performance } \\
\hline 1 & Common Equity Tier 1 ratio (\%) & n.a. & n.a. & n.a. & n.a. & n.a. & n.a. & n.a. & n.a. & n.a. & n.a. & n.a. \\
\hline 2 & Leverage ratio (\%) & 9.0 & 8.3 & 8.1 & 8.0 & 8.1 & 3.1 & 4.5 & 7.6 & 8.4 & 9.6 & 65.1 \\
\hline 3 & Efficiency Ratio (\%) (3) & 61.3 & 56.6 & 59.3 & 59.4 & 59.8 & 8.6 & 18.9 & 56.8 & 60.4 & 65.0 & 199.1 \\
\hline 4 & Pretax Return on Assets (\%) & 1.7 & 1.7 & 1.8 & 1.8 & 1.9 & 0.6 & -4.1 & 1.4 & 1.7 & 1.9 & 13.3 \\
\hline 5 & Net Interest Margin (\%) & 4.0 & 3.8 & 3.7 & 3.6 & 3.5 & 0.8 & 1.1 & 3.6 & 3.9 & 4.2 & 34.7 \\
\hline 6 & Non-performing assets ratio (\%) & 0.6 & 0.6 & 0.5 & 0.5 & 0.5 & 0.5 & 0.0 & 0.4 & 0.5 & 0.8 & 9.1 \\
\hline
\end{tabular}

Summary statistics: 2005

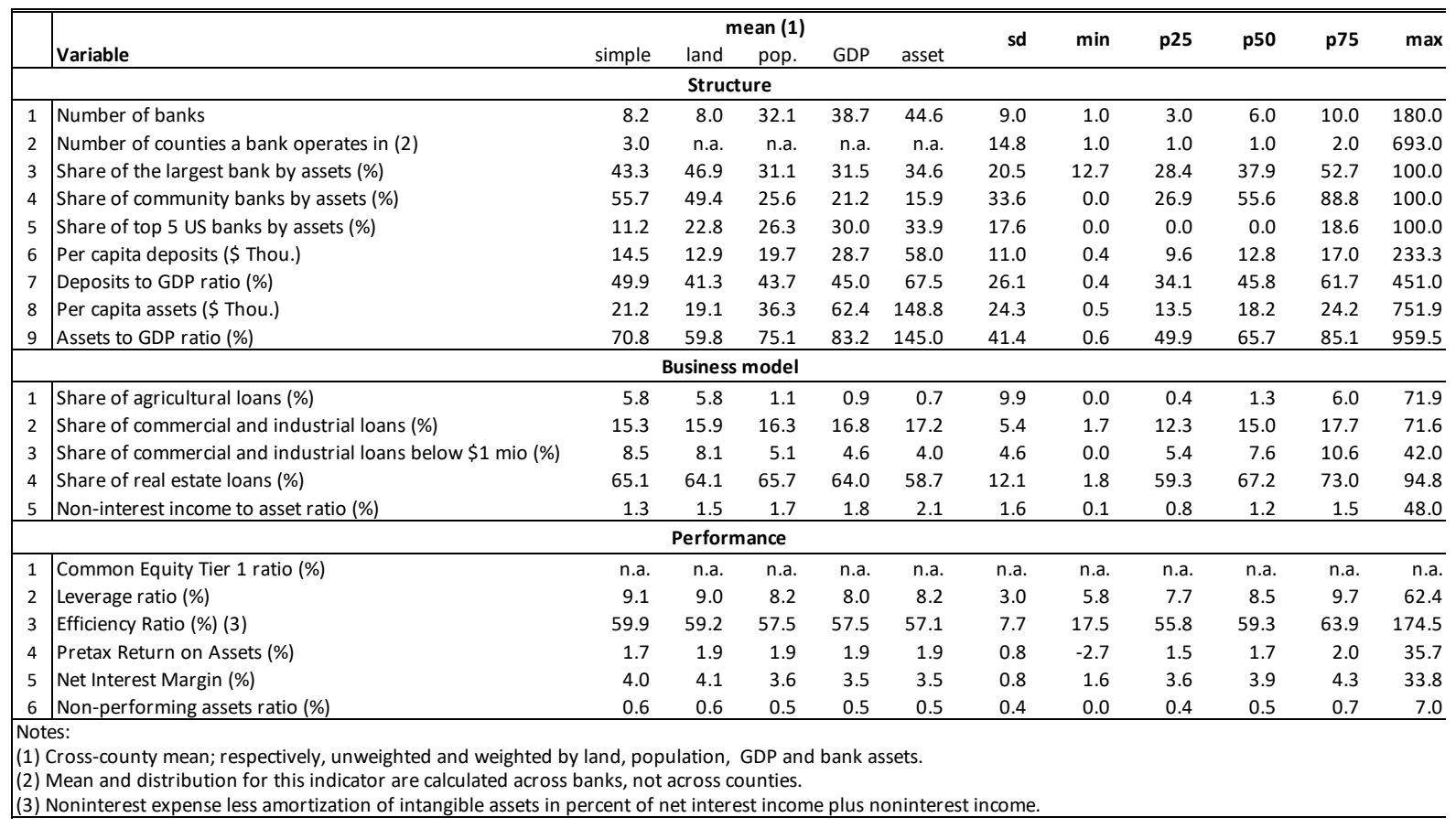




\begin{tabular}{|c|c|c|c|c|c|c|c|c|c|c|c|c|}
\hline & \multirow[b]{2}{*}{ Variable } & \multicolumn{5}{|c|}{ mean (1) } & \multirow{2}{*}{ sd } & \multirow{2}{*}{$\min$} & \multirow{2}{*}{ p25 } & \multirow{2}{*}{ p50 } & \multirow{2}{*}{ p75 } & \multirow{2}{*}{$\max$} \\
\hline & & simple & land & pop. & GDP & asset & & & & & & \\
\hline \multicolumn{13}{|c|}{ Structure } \\
\hline 1 & Number of banks & 8.5 & 7.6 & 33.1 & 39.6 & 46.5 & 9.3 & 1.0 & 3.0 & 6.0 & 10.0 & 174.0 \\
\hline 2 & Number of counties a bank operates in (2) & 3.2 & n.a. & n.a. & n.a. & n.a. & 15.7 & 1.0 & 1.0 & 1.0 & 2.0 & 691.0 \\
\hline 3 & Share of the largest bank by assets (\%) & 42.9 & 43.4 & 31.0 & 31.3 & 34.2 & 20.3 & 13.3 & 28.2 & 37.7 & 52.1 & 100.0 \\
\hline 4 & Share of community banks by assets (\%) & 55.0 & 45.7 & 24.9 & 20.8 & 15.0 & 33.7 & 0.0 & 25.3 & 55.2 & 87.1 & 100.0 \\
\hline 5 & Share of top 5 US banks by assets (\%) & 11.5 & 21.4 & 28.3 & 32.2 & 36.4 & 17.8 & 0.0 & 0.0 & 0.0 & 18.8 & 100.0 \\
\hline 6 & Per capita deposits (\$ Thou.) & 15.6 & 12.9 & 21.4 & 31.8 & 71.4 & 13.0 & 0.4 & 10.3 & 13.6 & 18.0 & 373.3 \\
\hline 7 & Deposits to GDP ratio (\%) & 50.0 & 38.8 & 44.3 & 46.5 & 74.8 & 27.5 & 0.2 & 34.3 & 45.8 & 61.1 & 559.7 \\
\hline 8 & Per capita assets (\$ Thou.) & 22.4 & 18.6 & 39.3 & 68.4 & 179.4 & 27.4 & 0.5 & 14.2 & 18.9 & 25.4 & 861.3 \\
\hline 9 & Assets to GDP ratio (\%) & 69.8 & 55.1 & 75.5 & 85.5 & 161.6 & 43.0 & 0.2 & 48.7 & 64.5 & 82.9 & 948.8 \\
\hline \multicolumn{13}{|c|}{ Business model } \\
\hline 1 & Share of agricultural loans (\%) & 5.7 & 5.4 & 1.1 & 0.9 & 0.7 & 9.8 & 0.0 & 0.4 & 1.3 & 6.0 & 73.0 \\
\hline 2 & Share of commercial and industrial loans (\%) & 15.4 & 15.2 & 16.8 & 17.3 & 17.6 & 5.2 & 1.3 & 12.4 & 15.1 & 18.0 & 65.8 \\
\hline 3 & Share of commercial and industrial loans below $\$ 1 \mathrm{mio}(\%)$ & 18.0 & 12.6 & 5.6 & 4.7 & 4.3 & 561.1 & 0.0 & 4.9 & 7.1 & 10.0 & 31683.3 \\
\hline 4 & Share of real estate loans (\%) & 65.4 & 59.3 & 66.1 & 64.6 & 59.6 & 12.1 & 1.3 & 60.0 & 67.3 & 73.5 & 97.3 \\
\hline 5 & Non-interest income to asset ratio (\%) & 1.3 & 1.4 & 1.6 & 1.7 & 2.1 & 1.3 & 0.1 & 0.9 & 1.2 & 1.5 & 39.0 \\
\hline \multicolumn{13}{|c|}{ Performance } \\
\hline 1 & Common Equity Tier 1 ratio (\%) & n.a. & n.a. & n.a. & n.a. & n.a. & n.a. & n.a. & n.a. & n.a. & n.a. & n.a. \\
\hline 2 & Leverage ratio (\%) & 9.2 & 8.6 & 8.2 & 8.1 & 8.2 & 2.9 & 6.0 & 7.9 & 8.7 & 9.8 & 62.1 \\
\hline 3 & Efficiency Ratio (\%) (3) & 60.2 & 55.2 & 58.1 & 58.0 & 57.2 & 7.3 & 7.4 & 56.1 & 59.9 & 64.3 & 145.8 \\
\hline 4 & Pretax Return on Assets (\%) & 1.7 & 1.7 & 1.7 & 1.7 & 1.9 & 0.6 & -4.5 & 1.4 & 1.7 & 1.9 & 11.0 \\
\hline 5 & Net Interest Margin (\%) & 3.9 & 3.9 & 3.4 & 3.4 & 3.4 & 0.9 & 1.4 & 3.5 & 3.9 & 4.3 & 41.8 \\
\hline 6 & Non-performing assets ratio (\%) & 0.6 & 0.7 & 0.5 & 0.5 & 0.5 & 0.4 & 0.0 & 0.4 & 0.5 & 0.8 & 5.9 \\
\hline
\end{tabular}

Summary statistics: 2007

\begin{tabular}{|c|c|c|c|c|c|c|c|c|c|c|c|c|}
\hline & \multicolumn{6}{|c|}{ mean (1) } & \multirow{2}{*}{ sd } & \multirow{2}{*}{$\min$} & \multirow{2}{*}{ p25 } & \multirow{2}{*}{ p50 } & \multirow{2}{*}{ p75 } & \multirow{2}{*}{$\max$} \\
\hline & Variable & simple & land & pop. & GDP & asset & & & & & & \\
\hline \multicolumn{13}{|c|}{ Structure } \\
\hline 1 & Number of banks & 8.7 & 7.8 & 34.4 & 41.2 & 47.2 & 9.7 & 1.0 & 3.0 & 6.0 & 10.0 & 179.0 \\
\hline 2 & Number of counties a bank operates in (2) & 3.3 & n.a. & n.a. & n.a. & n.a. & 16.2 & 1.0 & 1.0 & 1.0 & 3.0 & 693.0 \\
\hline 3 & Share of the largest bank by assets (\%) & 43.0 & 43.7 & 31.8 & 32.5 & 37.5 & 20.2 & 12.2 & 28.3 & 37.8 & 52.1 & 100.0 \\
\hline 4 & Share of community banks by assets (\%) & 54.2 & 44.6 & 23.9 & 19.9 & 14.0 & 33.9 & 0.0 & 24.4 & 53.6 & 86.5 & 100.0 \\
\hline 5 & Share of top 5 US banks by assets (\%) & 12.4 & 22.8 & 31.1 & 35.0 & 38.4 & 18.9 & 0.0 & 0.0 & 0.0 & 20.8 & 100.0 \\
\hline 6 & Per capita deposits (\$ Thou.) & 16.2 & 13.6 & 22.0 & 30.9 & 62.2 & 12.5 & 0.4 & 10.7 & 14.1 & 18.8 & 292.6 \\
\hline 7 & Deposits to GDP ratio (\%) & 49.4 & 38.0 & 44.8 & 46.2 & 77.4 & 26.4 & 0.2 & 33.9 & 45.4 & 60.9 & 435.4 \\
\hline 8 & Per capita assets (\$ Thou.) & 24.0 & 20.7 & 42.7 & 67.6 & 160.6 & 29.2 & 0.6 & 15.1 & 20.1 & 26.9 & 802.8 \\
\hline 9 & Assets to GDP ratio (\%) & 70.7 & 56.5 & 81.4 & 90.0 & 186.6 & 49.6 & 0.3 & 49.9 & 65.3 & 84.4 & 1417.3 \\
\hline \multicolumn{13}{|c|}{ Business model } \\
\hline 1 & Share of agricultural loans (\%) & 5.6 & 5.2 & 1.1 & 0.9 & 0.7 & 9.6 & 0.0 & 0.3 & 1.2 & 6.0 & 75.7 \\
\hline 2 & Share of commercial and industrial loans (\%) & 15.8 & 15.9 & 18.1 & 18.8 & 19.0 & 4.9 & 0.6 & 12.8 & 15.7 & 18.8 & 53.8 \\
\hline 3 & Share of commercial and industrial loans below $\$ 1$ mio (\%) & 7.8 & 7.2 & 4.7 & 4.3 & 3.8 & 4.2 & 0.0 & 4.8 & 6.9 & 9.7 & 41.1 \\
\hline 4 & Share of real estate loans (\%) & 65.1 & 58.6 & 64.3 & 62.5 & 57.7 & 11.9 & 1.3 & 59.0 & 66.9 & 73.1 & 96.1 \\
\hline 5 & Non-interest income to asset ratio (\%) & 1.3 & 1.4 & 1.5 & 1.6 & 1.9 & 1.2 & 0.1 & 0.9 & 1.2 & 1.5 & 39.5 \\
\hline \multicolumn{13}{|c|}{ Performance } \\
\hline 1 & Common Equity Tier 1 ratio (\%) & n.a. & n.a. & n.a. & n.a. & n.a. & n.a. & n.a. & n.a. & n.a. & n.a. & n.a. \\
\hline 2 & Leverage ratio (\%) & 9.0 & 8.3 & 8.0 & 7.8 & 8.0 & 2.7 & 5.0 & 7.7 & 8.5 & 9.6 & 53.8 \\
\hline 3 & Efficiency Ratio (\%) (3) & 62.1 & 56.9 & 62.0 & 62.0 & 61.4 & 7.3 & 16.6 & 58.4 & 61.8 & 65.7 & 132.0 \\
\hline 4 & Pretax Return on Assets (\%) & 1.4 & 1.4 & 1.2 & 1.2 & 1.2 & 0.6 & -3.6 & 1.1 & 1.4 & 1.7 & 11.2 \\
\hline 5 & Net Interest Margin (\%) & 3.9 & 3.8 & 3.4 & 3.3 & 3.3 & 0.9 & 1.6 & 3.4 & 3.8 & 4.2 & 43.0 \\
\hline 6 & Non-performing assets ratio (\%) & 1.0 & 1.0 & 1.0 & 1.0 & 1.0 & 0.8 & 0.0 & 0.6 & 0.8 & 1.2 & 11.4 \\
\hline
\end{tabular}




\begin{tabular}{|c|c|c|c|c|c|c|c|c|c|c|c|c|}
\hline & \multirow[b]{2}{*}{ Variable } & \multicolumn{5}{|c|}{ mean (1) } & \multirow{2}{*}{ sd } & \multirow{2}{*}{$\min$} & \multirow{2}{*}{ p25 } & \multirow{2}{*}{ p50 } & \multirow{2}{*}{ p75 } & \multirow{2}{*}{$\max$} \\
\hline & & simple & land & pop. & GDP & asset & & & & & & \\
\hline \multicolumn{13}{|c|}{ Structure } \\
\hline 1 & Number of banks & 8.8 & 7.9 & 34.6 & 40.9 & 47.7 & 9.8 & 1.0 & 4.0 & 6.0 & 10.0 & 175.0 \\
\hline 2 & Number of counties a bank operates in (2) & 3.4 & n.a. & n.a. & n.a. & n.a. & 17.2 & 1.0 & 1.0 & 1.0 & 3.0 & 725.0 \\
\hline 3 & Share of the largest bank by assets (\%) & 42.9 & 43.6 & 31.4 & 32.1 & 37.1 & 20.3 & 11.5 & 28.2 & 37.6 & 52.2 & 100.0 \\
\hline 4 & Share of community banks by assets (\%) & 54.3 & 43.8 & 24.0 & 20.2 & 13.8 & 33.8 & 0.0 & 24.9 & 54.0 & 86.6 & 100.0 \\
\hline 5 & Share of top 5 US banks by assets (\%) & 12.6 & 24.3 & 33.8 & 37.7 & 40.7 & 19.3 & 0.0 & 0.0 & 0.0 & 20.7 & 100.0 \\
\hline 6 & Per capita deposits (\$ Thou.) & 17.0 & 14.3 & 22.8 & 31.7 & 69.3 & 14.1 & 0.8 & 11.0 & 14.4 & 19.7 & 345.8 \\
\hline 7 & Deposits to GDP ratio (\%) & 50.1 & 38.6 & 45.9 & 47.6 & 87.4 & 29.2 & 0.1 & 33.8 & 45.9 & 61.6 & 512.5 \\
\hline 8 & Per capita assets (\$ Thou.) & 25.1 & 22.0 & 45.0 & 69.9 & 181.8 & 31.4 & 1.0 & 15.5 & 20.6 & 27.8 & 810.9 \\
\hline 9 & Assets to GDP ratio (\%) & 71.7 & 58.1 & 84.6 & 94.0 & 216.2 & 50.9 & 0.2 & 50.1 & 65.8 & 84.9 & 1113.7 \\
\hline \multicolumn{13}{|c|}{ Business model } \\
\hline 1 & Share of agricultural loans (\%) & 5.5 & 5.1 & 1.1 & 1.0 & 0.7 & 9.5 & 0.0 & 0.3 & 1.2 & 5.9 & 75.0 \\
\hline 2 & Share of commercial and industrial loans (\%) & 16.0 & 16.5 & 19.1 & 19.8 & 20.1 & 5.1 & 1.0 & 12.7 & 16.1 & 19.3 & 53.0 \\
\hline 3 & Share of commercial and industrial loans below $\$ 1 \mathrm{mio}(\%)$ & 7.6 & 6.9 & 4.6 & 4.3 & 3.7 & 4.1 & 0.4 & 4.8 & 6.6 & 9.3 & 38.6 \\
\hline 4 & Share of real estate loans (\%) & 65.6 & 58.6 & 63.6 & 62.0 & 56.7 & 11.8 & 0.8 & 59.5 & 67.0 & 73.4 & 93.6 \\
\hline 5 & Non-interest income to asset ratio (\%) & 1.1 & 1.3 & 1.3 & 1.4 & 1.6 & 1.0 & 0.0 & 0.8 & 1.0 & 1.3 & 36.1 \\
\hline \multicolumn{13}{|c|}{ Performance } \\
\hline 1 & Common Equity Tier 1 ratio (\%) & n.a. & n.a. & n.a. & n.a. & n.a. & n.a. & n.a. & n.a. & n.a. & n.a. & n.a. \\
\hline 2 & Leverage ratio (\%) & 8.6 & 7.8 & 7.5 & 7.4 & 7.6 & 1.7 & 4.6 & 7.6 & 8.3 & 9.3 & 26.9 \\
\hline 3 & Efficiency Ratio (\%) (3) & 62.2 & 56.8 & 60.1 & 60.5 & 86.1 & 22.6 & -100.3 & 56.5 & 61.4 & 66.5 & 1127.4 \\
\hline 4 & Pretax Return on Assets (\%) & 0.5 & 0.6 & 0.1 & 0.2 & 0.1 & 1.0 & -9.5 & 0.1 & 0.7 & 1.2 & 11.6 \\
\hline 5 & Net Interest Margin (\%) & 3.7 & 3.6 & 3.2 & 3.1 & 3.2 & 0.8 & 0.8 & 3.3 & 3.7 & 4.0 & 23.5 \\
\hline 6 & Non-performing assets ratio (\%) & 1.9 & 1.8 & 2.0 & 1.9 & 1.9 & 1.2 & 0.0 & 1.1 & 1.7 & 2.3 & 20.4 \\
\hline
\end{tabular}

Summary statistics: 2009

\begin{tabular}{|c|c|c|c|c|c|c|c|c|c|c|c|c|}
\hline & \multicolumn{6}{|c|}{ mean (1) } & \multirow{2}{*}{ sd } & \multirow{2}{*}{$\min$} & \multirow{2}{*}{ p25 } & \multirow{2}{*}{ p50 } & \multirow{2}{*}{ p75 } & \multirow{2}{*}{$\max$} \\
\hline & Variable & simple & land & pop. & GDP & asset & & & & & & \\
\hline \multicolumn{13}{|c|}{ Structure } \\
\hline 1 & Number of banks & 8.8 & 7.9 & 33.9 & 40.1 & 45.8 & 9.6 & 1.0 & 4.0 & 6.0 & 11.0 & 167.0 \\
\hline 2 & Number of counties a bank operates in (2) & 3.5 & n.a. & n.a. & n.a. & n.a. & 18.0 & 1.0 & 1.0 & 2.0 & 3.0 & 727.0 \\
\hline 3 & Share of the largest bank by assets (\%) & 42.7 & 43.7 & 31.2 & 32.0 & 37.2 & 20.3 & 11.0 & 27.9 & 37.4 & 52.3 & 100.0 \\
\hline 4 & Share of community banks by assets (\%) & 55.6 & 44.7 & 25.4 & 21.3 & 15.1 & 33.4 & 0.0 & 26.6 & 55.9 & 87.6 & 100.0 \\
\hline 5 & Share of top 5 US banks by assets (\%) & 11.7 & 23.5 & 32.9 & 36.9 & 41.1 & 18.4 & 0.0 & 0.0 & 0.0 & 19.5 & 100.0 \\
\hline 6 & Per capita deposits (\$ Thou.) & 17.8 & 15.0 & 24.4 & 34.7 & 76.0 & 15.6 & 1.4 & 11.2 & 15.0 & 20.7 & 399.1 \\
\hline 7 & Deposits to GDP ratio (\%) & 53.4 & 41.8 & 49.7 & 52.3 & 97.9 & 33.1 & 0.2 & 36.2 & 48.6 & 64.8 & 810.1 \\
\hline 8 & Per capita assets (\$ Thou.) & 24.6 & 21.4 & 42.2 & 67.2 & 167.3 & 30.2 & 1.6 & 15.0 & 20.1 & 27.5 & 784.4 \\
\hline 9 & Assets to GDP ratio (\%) & 71.9 & 58.7 & 81.4 & 90.7 & 200.9 & 50.3 & 0.4 & 49.4 & 66.0 & 85.4 & 1187.4 \\
\hline \multicolumn{13}{|c|}{ Business model } \\
\hline 1 & Share of agricultural loans (\%) & 5.6 & 5.2 & 1.1 & 1.0 & 0.7 & 9.5 & 0.0 & 0.3 & 1.3 & 5.9 & 72.9 \\
\hline 2 & Share of commercial and industrial loans (\%) & 14.5 & 14.3 & 16.6 & 17.1 & 17.1 & 4.7 & 0.8 & 11.6 & 14.4 & 17.0 & 77.2 \\
\hline 3 & Share of commercial and industrial loans below $\$ 1$ mio (\%) & 7.4 & 6.7 & 4.7 & 4.3 & 3.9 & 3.9 & 0.4 & 4.7 & 6.5 & 9.0 & 42.1 \\
\hline 4 & Share of real estate loans (\%) & 67.4 & 61.6 & 65.8 & 64.2 & 58.8 & 11.7 & 0.8 & 61.8 & 69.1 & 75.0 & 94.0 \\
\hline 5 & Non-interest income to asset ratio (\%) & 1.3 & 1.5 & 1.7 & 1.8 & 2.0 & 0.9 & -1.1 & 0.8 & 1.2 & 1.6 & 25.3 \\
\hline \multicolumn{13}{|c|}{ Performance } \\
\hline 1 & Common Equity Tier 1 ratio (\%) & n.a. & n.a. & n.a. & n.a. & n.a. & n.a. & n.a. & n.a. & n.a. & n.a. & n.a. \\
\hline 2 & Leverage ratio (\%) & 8.9 & 8.2 & 8.3 & 8.2 & 8.6 & 1.8 & 3.0 & 8.0 & 8.6 & 9.5 & 57.7 \\
\hline 3 & Efficiency Ratio (\%) (3) & 66.3 & 59.1 & 61.6 & 60.5 & 57.9 & 14.5 & 19.4 & 59.5 & 64.0 & 69.9 & 435.3 \\
\hline 4 & Pretax Return on Assets (\%) & 0.3 & 0.4 & 0.1 & 0.1 & 0.0 & 1.2 & -12.8 & -0.2 & 0.5 & 1.0 & 12.3 \\
\hline 5 & Net Interest Margin (\%) & 3.8 & 3.7 & 3.5 & 3.4 & 3.5 & 0.6 & 0.4 & 3.4 & 3.7 & 4.0 & 13.8 \\
\hline 6 & Non-performing assets ratio (\%) & 3.2 & 3.2 & 3.6 & 3.5 & 3.4 & 2.0 & 0.0 & 1.8 & 2.9 & 4.0 & 17.1 \\
\hline
\end{tabular}




\begin{tabular}{|c|c|c|c|c|c|c|c|c|c|c|c|c|}
\hline & \multirow[b]{2}{*}{ Variable } & \multicolumn{5}{|c|}{ mean (1) } & \multirow{2}{*}{ sd } & \multirow{2}{*}{$\min$} & \multirow{2}{*}{ p25 } & \multirow{2}{*}{ p50 } & \multirow{2}{*}{ p75 } & \multirow{2}{*}{$\max$} \\
\hline & & simple & land & pop. & GDP & asset & & & & & & \\
\hline \multicolumn{13}{|c|}{ Structure } \\
\hline 1 & Number of banks & 8.7 & 8.3 & 32.7 & 38.9 & 44.7 & 9.4 & 1.0 & 4.0 & 6.0 & 10.0 & 158.0 \\
\hline 2 & Number of counties a bank operates in (2) & 3.7 & n.a. & n.a. & n.a. & n.a. & 19.8 & 1.0 & 1.0 & 2.0 & 3.0 & 931.0 \\
\hline 3 & Share of the largest bank by assets (\%) & 43.0 & 46.7 & 31.0 & 31.9 & 37.7 & 20.5 & 11.7 & 28.1 & 37.7 & 52.7 & 100.0 \\
\hline 4 & Share of community banks by assets (\%) & 55.6 & 48.2 & 25.2 & 21.1 & 14.6 & 33.6 & 0.0 & 26.3 & 56.5 & 87.6 & 100.0 \\
\hline 5 & Share of top 5 US banks by assets (\%) & 13.9 & 27.7 & 36.2 & 40.4 & 42.7 & 19.9 & 0.0 & 0.0 & 0.0 & 23.1 & 100.0 \\
\hline 6 & Per capita deposits (\$ Thou.) & 17.8 & 16.0 & 24.6 & 36.9 & 93.6 & 18.0 & 1.5 & 11.1 & 15.0 & 20.6 & 549.6 \\
\hline 7 & Deposits to GDP ratio (\%) & 51.4 & 43.1 & 48.3 & 51.2 & 109.6 & 33.3 & 0.2 & 34.8 & 46.9 & 62.6 & 771.2 \\
\hline 8 & Per capita assets (\$ Thou.) & 24.3 & 22.3 & 42.7 & 71.7 & 205.8 & 37.5 & 1.7 & 14.5 & 19.7 & 27.1 & 1239.6 \\
\hline 9 & Assets to GDP ratio (\%) & 68.1 & 59.2 & 78.7 & 89.0 & 228.0 & 56.4 & 0.3 & 47.0 & 61.9 & 80.8 & 1739.4 \\
\hline \multicolumn{13}{|c|}{ Business model } \\
\hline 1 & Share of agricultural loans (\%) & 5.6 & 5.5 & 1.1 & 1.0 & 0.7 & 9.5 & 0.0 & 0.3 & 1.2 & 6.2 & 76.8 \\
\hline 2 & Share of commercial and industrial loans (\%) & 14.2 & 15.1 & 16.5 & 17.0 & 16.5 & 4.6 & 1.1 & 11.3 & 14.2 & 16.7 & 52.6 \\
\hline 3 & Share of commercial and industrial loans below $\$ 1 \mathrm{mio}(\%)$ & 6.9 & 6.6 & 4.4 & 4.1 & 3.6 & 3.8 & 0.5 & 4.4 & 6.0 & 8.5 & 51.6 \\
\hline 4 & Share of real estate loans (\%) & 67.4 & 65.7 & 64.6 & 62.8 & 56.4 & 11.6 & 1.9 & 61.8 & 68.9 & 75.0 & 93.7 \\
\hline 5 & Non-interest income to asset ratio (\%) & 1.2 & 1.4 & 1.6 & 1.7 & 1.8 & 0.7 & -0.7 & 0.8 & 1.1 & 1.5 & 22.0 \\
\hline \multicolumn{13}{|c|}{ Performance } \\
\hline 1 & Common Equity Tier 1 ratio (\%) & n.a. & n.a. & n.a. & n.a. & n.a. & n.a. & n.a. & n.a. & n.a. & n.a. & n.a. \\
\hline 2 & Leverage ratio (\%) & 9.2 & 9.3 & 8.8 & 8.7 & 8.9 & 1.5 & 2.1 & 8.5 & 9.0 & 9.8 & 26.2 \\
\hline 3 & Efficiency Ratio (\%) (3) & 66.0 & 64.1 & 63.3 & 62.7 & 59.8 & 11.4 & -45.9 & 60.5 & 64.5 & 69.6 & 293.1 \\
\hline 4 & Pretax Return on Assets (\%) & 0.7 & 0.8 & 0.8 & 0.8 & 1.0 & 0.9 & -6.7 & 0.4 & 0.9 & 1.2 & 12.0 \\
\hline 5 & Net Interest Margin (\%) & 3.9 & 3.9 & 3.6 & 3.5 & 3.8 & 0.6 & 0.2 & 3.6 & 3.8 & 4.1 & 19.2 \\
\hline 6 & Non-performing assets ratio (\%) & 3.2 & 3.3 & 3.4 & 3.4 & 3.1 & 2.2 & 0.0 & 1.8 & 2.8 & 4.1 & 22.1 \\
\hline
\end{tabular}

\section{Summary statistics: 2011}

\begin{tabular}{|c|c|c|c|c|c|c|c|c|c|c|c|c|}
\hline & \multirow[b]{2}{*}{ Variable } & \multicolumn{5}{|c|}{ mean (1) } & \multirow{2}{*}{ sd } & \multirow{2}{*}{$\min$} & \multirow{2}{*}{ p25 } & \multirow{2}{*}{ p50 } & \multirow{2}{*}{ p75 } & \multirow{2}{*}{$\max$} \\
\hline & & simple & land & pop. & GDP & asset & & & & & & \\
\hline \multicolumn{13}{|c|}{ Structure } \\
\hline 1 & Number of banks & 8.7 & 8.2 & 32.1 & 38.0 & 44.2 & 9.2 & 1.0 & 4.0 & 6.0 & 10.0 & 147.0 \\
\hline 2 & Number of counties a bank operates in (2) & 3.8 & n.a. & n.a. & n.a. & n.a. & 20.6 & 1.0 & 1.0 & 2.0 & 3.0 & 925.0 \\
\hline 3 & Share of the largest bank by assets (\%) & 43.2 & 46.7 & 31.1 & 32.1 & 39.7 & 20.5 & 11.5 & 28.1 & 38.2 & 52.9 & 100.0 \\
\hline 4 & Share of community banks by assets (\%) & 56.2 & 49.2 & 25.3 & 21.4 & 14.2 & 33.8 & 0.0 & 26.6 & 57.6 & 88.5 & 100.0 \\
\hline 5 & Share of top 5 US banks by assets (\%) & 13.4 & 27.3 & 35.3 & 39.3 & 43.6 & 19.6 & 0.0 & 0.0 & 0.0 & 22.1 & 100.0 \\
\hline 6 & Per capita deposits (\$ Thou.) & 18.3 & 16.5 & 26.2 & 41.1 & 106.7 & 18.4 & 1.3 & 11.2 & 15.2 & 21.1 & 521.8 \\
\hline 7 & Deposits to GDP ratio (\%) & 49.6 & 41.7 & 49.0 & 53.2 & 114.5 & 30.3 & 0.2 & 34.2 & 46.0 & 60.6 & 618.3 \\
\hline 8 & Per capita assets (\$ Thou.) & 24.6 & 22.9 & 44.3 & 76.9 & 223.2 & 34.0 & 1.6 & 14.5 & 19.7 & 27.6 & 974.5 \\
\hline 9 & Assets to GDP ratio (\%) & 65.0 & 57.0 & 78.5 & 89.9 & 231.9 & 48.0 & 0.2 & 45.3 & 59.8 & 77.3 & 1154.7 \\
\hline \multicolumn{13}{|c|}{ Business model } \\
\hline 1 & Share of agricultural loans (\%) & 5.7 & 5.6 & 1.2 & 1.1 & 0.7 & 9.5 & 0.0 & 0.3 & 1.2 & 6.2 & 78.9 \\
\hline 2 & Share of commercial and industrial loans (\%) & 14.9 & 16.0 & 18.0 & 18.6 & 18.1 & 5.0 & 0.7 & 11.6 & 14.7 & 17.8 & 54.4 \\
\hline 3 & Share of commercial and industrial loans below $\$ 1$ mio (\%) & 6.7 & 6.5 & 4.3 & 4.0 & 3.4 & 3.8 & 0.0 & 4.2 & 5.9 & 8.4 & 47.3 \\
\hline 4 & Share of real estate loans (\%) & 66.6 & 64.6 & 62.1 & 60.0 & 52.9 & 11.7 & 1.4 & 60.1 & 68.2 & 74.4 & 92.0 \\
\hline 5 & Non-interest income to asset ratio (\%) & 1.1 & 1.3 & 1.5 & 1.6 & 1.7 & 0.8 & -1.8 & 0.8 & 1.1 & 1.4 & 31.0 \\
\hline \multicolumn{13}{|c|}{ Performance } \\
\hline 1 & Common Equity Tier 1 ratio (\%) & n.a. & n.a. & n.a. & n.a. & n.a. & n.a. & n.a. & n.a. & n.a. & n.a. & n.a. \\
\hline 2 & Leverage ratio (\%) & 9.6 & 9.6 & 9.1 & 8.9 & 9.1 & 1.4 & 0.4 & 8.8 & 9.3 & 10.1 & 22.5 \\
\hline 3 & Efficiency Ratio (\%) (3) & 67.7 & 65.5 & 66.7 & 66.2 & 63.9 & 21.0 & -59.2 & 61.4 & 65.9 & 70.5 & 745.1 \\
\hline 4 & Pretax Return on Assets (\%) & 1.0 & 1.2 & 1.0 & 1.1 & 1.3 & 0.8 & -5.6 & 0.8 & 1.1 & 1.4 & 21.9 \\
\hline 5 & Net Interest Margin (\%) & 3.9 & 3.9 & 3.6 & 3.5 & 3.6 & 0.6 & 1.9 & 3.6 & 3.8 & 4.1 & 19.9 \\
\hline 6 & Non-performing assets ratio (\%) & 2.9 & 2.7 & 2.9 & 2.9 & 2.6 & 2.1 & 0.0 & 1.6 & 2.5 & 3.5 & 21.3 \\
\hline
\end{tabular}




\begin{tabular}{|c|c|c|c|c|c|c|c|c|c|c|c|c|}
\hline & \multirow[b]{2}{*}{ Variable } & \multicolumn{5}{|c|}{ mean (1) } & \multirow{2}{*}{ sd } & \multirow{2}{*}{$\min$} & \multirow{2}{*}{ p25 } & \multirow{2}{*}{ p50 } & \multirow{2}{*}{ p75 } & \multirow{2}{*}{$\max$} \\
\hline & & simple & land & pop. & GDP & asset & & & & & & \\
\hline \multicolumn{13}{|c|}{ Structure } \\
\hline 1 & Number of banks & 8.6 & 8.2 & 31.5 & 37.5 & 42.4 & 9.0 & 1.0 & 3.0 & 6.0 & 10.0 & 139.0 \\
\hline 2 & Number of counties a bank operates in (2) & 3.9 & n.a. & n.a. & n.a. & n.a. & 21.2 & 1.0 & 1.0 & 2.0 & 3.0 & 927.0 \\
\hline 3 & Share of the largest bank by assets (\%) & 43.3 & 46.9 & 30.6 & 31.8 & 40.0 & 20.6 & 10.7 & 28.1 & 38.0 & 52.8 & 100.0 \\
\hline 4 & Share of community banks by assets (\%) & 56.5 & 49.0 & 25.1 & 21.2 & 13.9 & 33.5 & 0.0 & 27.1 & 58.1 & 88.9 & 100.0 \\
\hline 5 & Share of top 5 US banks by assets (\%) & 13.3 & 27.1 & 34.8 & 38.8 & 43.6 & 19.5 & 0.0 & 0.0 & 0.0 & 21.8 & 100.0 \\
\hline 6 & Per capita deposits (\$ Thou.) & 19.4 & 17.4 & 28.3 & 46.3 & 212.2 & 35.8 & 1.0 & 11.3 & 15.6 & 21.7 & 1708.5 \\
\hline 7 & Deposits to GDP ratio (\%) & 50.2 & 42.1 & 49.6 & 55.3 & 226.0 & 46.4 & 0.2 & 34.0 & 45.6 & 60.8 & 1992.4 \\
\hline 8 & Per capita assets (\$ Thou.) & 26.5 & 23.9 & 45.7 & 83.2 & 496.9 & 93.2 & 1.4 & 14.5 & 19.8 & 28.2 & 4875.6 \\
\hline 9 & Assets to GDP ratio (\%) & 66.0 & 56.7 & 75.5 & 89.6 & 522.7 & 112.0 & 0.2 & 44.8 & 59.1 & 77.0 & 5685.8 \\
\hline \multicolumn{13}{|c|}{ Business model } \\
\hline 1 & Share of agricultural loans (\%) & 5.8 & 5.6 & 1.2 & 1.1 & 0.8 & 9.6 & 0.0 & 0.3 & 1.3 & 6.4 & 78.8 \\
\hline 2 & Share of commercial and industrial loans (\%) & 15.4 & 16.5 & 19.0 & 19.7 & 19.3 & 5.3 & 0.6 & 11.9 & 15.2 & 18.5 & 57.0 \\
\hline 3 & Share of commercial and industrial loans below $\$ 1 \mathrm{mio}(\%)$ & 6.6 & 6.4 & 4.1 & 3.9 & 3.3 & 3.8 & 0.4 & 4.0 & 5.8 & 8.2 & 38.1 \\
\hline 4 & Share of real estate loans (\%) & 65.9 & 64.0 & 60.6 & 58.4 & 50.8 & 11.6 & 0.2 & 59.4 & 67.1 & 73.6 & 91.6 \\
\hline 5 & Non-interest income to asset ratio (\%) & 1.2 & 1.4 & 1.6 & 1.6 & 1.8 & 0.8 & -1.3 & 0.8 & 1.1 & 1.5 & 30.1 \\
\hline \multicolumn{13}{|c|}{ Performance } \\
\hline 1 & Common Equity Tier 1 ratio (\%) & n.a. & n.a. & n.a. & n.a. & n.a. & n.a. & n.a. & n.a. & n.a. & n.a. & n.a. \\
\hline 2 & Leverage ratio (\%) & 9.7 & 9.7 & 9.2 & 9.1 & 9.1 & 1.4 & 2.1 & 8.9 & 9.5 & 10.3 & 20.1 \\
\hline 3 & Efficiency Ratio (\%) (3) & 67.0 & 64.9 & 67.6 & 66.8 & 64.8 & 16.3 & 21.6 & 61.4 & 65.6 & 70.2 & 433.4 \\
\hline 4 & Pretax Return on Assets (\%) & 1.2 & 1.4 & 1.3 & 1.3 & 1.4 & 0.6 & -5.1 & 1.0 & 1.3 & 1.5 & 21.9 \\
\hline 5 & Net Interest Margin (\%) & 3.8 & 3.7 & 3.4 & 3.3 & 3.4 & 0.6 & 1.6 & 3.5 & 3.7 & 4.0 & 19.3 \\
\hline 6 & Non-performing assets ratio (\%) & 2.4 & 2.3 & 2.4 & 2.4 & 2.2 & 1.9 & 0.0 & 1.3 & 2.0 & 2.8 & 24.2 \\
\hline
\end{tabular}

Summary statistics: 2013

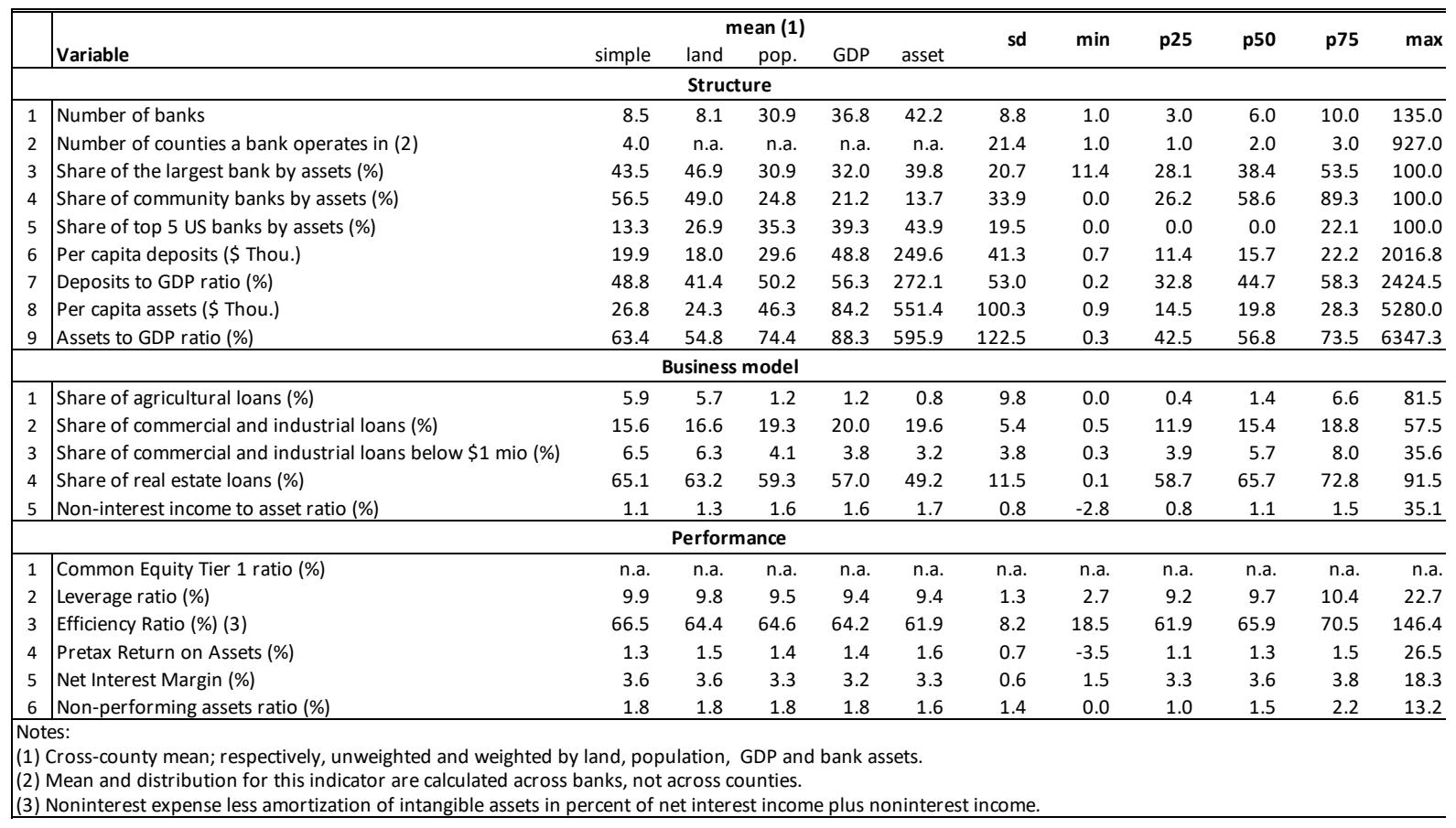




\begin{tabular}{|c|c|c|c|c|c|c|c|c|c|c|c|c|}
\hline & \multirow[b]{2}{*}{ Variable } & \multicolumn{5}{|c|}{ mean (1) } & \multirow{2}{*}{ sd } & \multirow{2}{*}{$\min$} & \multirow{2}{*}{ p25 } & \multirow{2}{*}{ p50 } & \multirow{2}{*}{ p75 } & \multirow{2}{*}{$\max$} \\
\hline & & simple & land & pop. & GDP & asset & & & & & & \\
\hline \multicolumn{13}{|c|}{ Structure } \\
\hline 1 & Number of banks & 8.4 & 8.0 & 30.2 & 36.2 & 41.9 & 8.7 & 1.0 & 3.0 & 6.0 & 10.0 & 129.0 \\
\hline 2 & Number of counties a bank operates in (2) & 4.1 & n.a. & n.a. & n.a. & n.a. & 21.5 & 1.0 & 1.0 & 2.0 & 3.0 & 930.0 \\
\hline 3 & Share of the largest bank by assets (\%) & 43.9 & 47.3 & 31.0 & 32.3 & 39.9 & 20.9 & 11.8 & 28.3 & 38.8 & 53.8 & 100.0 \\
\hline 4 & Share of community banks by assets (\%) & 56.3 & 48.2 & 24.4 & 20.7 & 13.3 & 34.2 & 0.0 & 25.0 & 58.2 & 90.2 & 100.0 \\
\hline 5 & Share of top 5 US banks by assets (\%) & 12.7 & 25.8 & 34.9 & 39.0 & 44.6 & 19.0 & 0.0 & 0.0 & 0.0 & 21.2 & 100.0 \\
\hline 6 & Per capita deposits (\$ Thou.) & 20.5 & 18.7 & 31.5 & 54.1 & 274.4 & 45.1 & 1.6 & 11.6 & 15.9 & 22.5 & 2213.0 \\
\hline 7 & Deposits to GDP ratio (\%) & 48.9 & 41.6 & 50.6 & 57.7 & 279.9 & 54.2 & 0.3 & 32.5 & 44.2 & 59.0 & 2516.1 \\
\hline 8 & Per capita assets (\$ Thou.) & 27.7 & 25.2 & 48.6 & 89.8 & 571.7 & 103.8 & 1.8 & 14.7 & 20.3 & 29.0 & 5449.7 \\
\hline 9 & Assets to GDP ratio (\%) & 63.9 & 55.0 & 74.6 & 89.2 & 584.1 & 119.7 & 0.4 & 42.8 & 56.4 & 74.4 & 6196.1 \\
\hline \multicolumn{13}{|c|}{ Business model } \\
\hline 1 & Share of agricultural loans (\%) & 6.2 & 5.9 & 1.3 & 1.2 & 0.8 & 10.2 & 0.0 & 0.4 & 1.5 & 7.0 & 81.0 \\
\hline 2 & Share of commercial and industrial loans (\%) & 15.8 & 16.7 & 19.9 & 20.6 & 20.3 & 5.6 & 0.4 & 12.0 & 15.6 & 19.1 & 61.3 \\
\hline 3 & Share of commercial and industrial loans below \$1 mio (\%) & 6.4 & 6.2 & 4.0 & 3.8 & 3.2 & 3.6 & 0.3 & 4.0 & 5.7 & 7.9 & 36.6 \\
\hline 4 & Share of real estate loans (\%) & 64.2 & 62.5 & 57.3 & 54.9 & 47.6 & 11.7 & 0.1 & 57.4 & 64.4 & 72.1 & 93.1 \\
\hline 5 & Non-interest income to asset ratio (\%) & 1.1 & 1.2 & 1.4 & 1.5 & 1.6 & 0.8 & -0.1 & 0.8 & 1.0 & 1.3 & 33.3 \\
\hline \multicolumn{13}{|c|}{ Performance } \\
\hline 1 & Common Equity Tier 1 ratio (\%) & 1.7 & 3.0 & 5.0 & 5.7 & 7.4 & 2.4 & 0.0 & 0.0 & 0.5 & 2.9 & 27.2 \\
\hline 2 & Leverage ratio $(\%)$ & 10.0 & 9.8 & 9.6 & 9.4 & 9.4 & 1.4 & 2.9 & 9.2 & 9.8 & 10.6 & 23.1 \\
\hline 3 & Efficiency Ratio (\%) (3) & 65.8 & 63.9 & 64.6 & 64.3 & 62.9 & 7.8 & 18.6 & 61.7 & 65.3 & 69.6 & 144.6 \\
\hline 4 & Pretax Return on Assets (\%) & 1.3 & 1.5 & 1.4 & 1.4 & 1.5 & 0.6 & -3.0 & 1.1 & 1.3 & 1.5 & 25.4 \\
\hline 5 & Net Interest Margin (\%) & 3.6 & 3.5 & 3.2 & 3.1 & 3.1 & 0.6 & 0.8 & 3.3 & 3.5 & 3.8 & 18.3 \\
\hline 6 & Non-performing assets ratio (\%) & 1.4 & 1.3 & 1.3 & 1.3 & 1.2 & 1.3 & 0.0 & 0.8 & 1.2 & 1.5 & 13.9 \\
\hline
\end{tabular}

Summary statistics: 2015

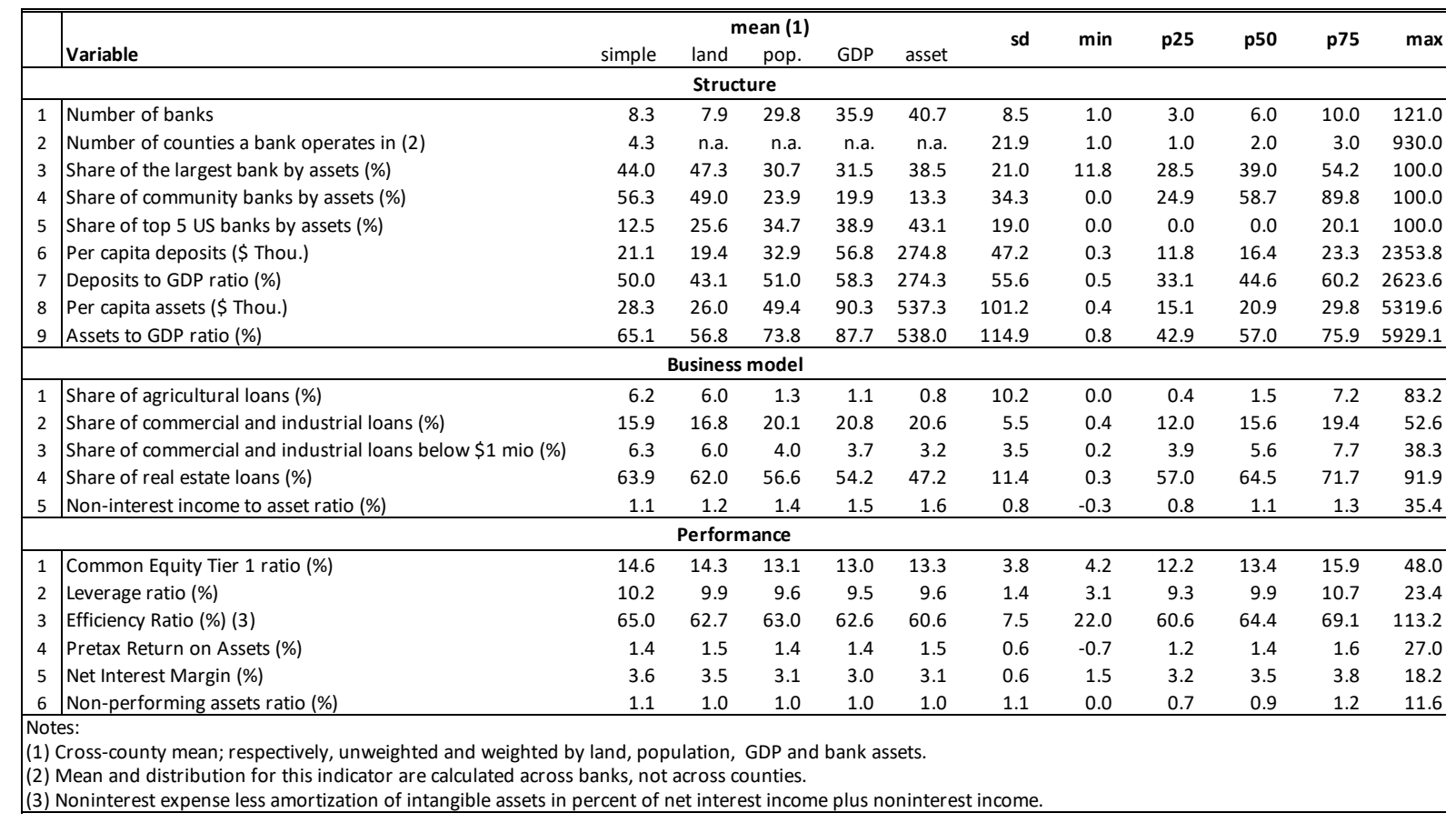




\begin{tabular}{|c|c|c|c|c|c|c|c|c|c|c|c|c|}
\hline & \multirow[b]{2}{*}{ Variable } & \multicolumn{5}{|c|}{ mean (1) } & \multirow{2}{*}{ sd } & \multirow{2}{*}{$\min$} & \multirow{2}{*}{ p25 } & \multirow{2}{*}{ p50 } & \multirow{2}{*}{ p75 } & \multirow{2}{*}{$\max$} \\
\hline & & simple & land & pop. & GDP & asset & & & & & & \\
\hline \multicolumn{13}{|c|}{ Structure } \\
\hline 1 & Number of banks & 8.3 & 7.8 & 29.4 & 35.7 & 41.2 & 8.5 & 1.0 & 3.0 & 6.0 & 10.0 & 116.0 \\
\hline 2 & Number of counties a bank operates in (2) & 4.5 & n.a. & n.a. & n.a. & n.a. & 22.4 & 1.0 & 1.0 & 2.0 & 3.0 & 928.0 \\
\hline 3 & Share of the largest bank by assets (\%) & 44.2 & 47.8 & 30.9 & 31.6 & 38.3 & 21.1 & 11.4 & 28.5 & 39.2 & 54.2 & 100.0 \\
\hline 4 & Share of community banks by assets (\%) & 55.8 & 48.6 & 23.5 & 19.3 & 13.0 & 34.4 & 0.0 & 24.3 & 58.1 & 89.4 & 100.0 \\
\hline 5 & Share of top 5 US banks by assets (\%) & 12.5 & 25.7 & 35.0 & 39.4 & 43.4 & 19.1 & 0.0 & 0.0 & 0.0 & 20.2 & 100.0 \\
\hline 6 & Per capita deposits (\$ Thou.) & 21.5 & 19.9 & 34.6 & 61.5 & 273.2 & 47.4 & 0.5 & 12.1 & 16.8 & 23.9 & 2331.7 \\
\hline 7 & Deposits to GDP ratio (\%) & 51.1 & 44.5 & 52.4 & 60.1 & 258.8 & 54.9 & 0.6 & 33.8 & 45.7 & 61.6 & 2526.1 \\
\hline 8 & Per capita assets (\$ Thou.) & 28.8 & 26.7 & 51.6 & 97.4 & 511.8 & 97.4 & 0.6 & 15.5 & 21.4 & 30.6 & 5062.6 \\
\hline 9 & Assets to GDP ratio (\%) & 66.5 & 58.6 & 75.3 & 89.7 & 483.5 & 108.2 & 1.0 & 43.8 & 58.3 & 77.7 & 5484.7 \\
\hline \multicolumn{13}{|c|}{ Business model } \\
\hline 1 & Share of agricultural loans (\%) & 5.9 & 5.7 & 1.2 & 1.0 & 0.7 & 9.6 & 0.0 & 0.3 & 1.5 & 7.0 & 83.0 \\
\hline 2 & Share of commercial and industrial loans (\%) & 15.8 & 16.8 & 20.3 & 21.1 & 20.8 & 5.4 & 0.2 & 11.9 & 15.5 & 19.3 & 47.5 \\
\hline 3 & Share of commercial and industrial loans below $\$ 1 \mathrm{mio}(\%)$ & 6.2 & 5.9 & 3.9 & 3.6 & 3.1 & 3.3 & 0.2 & 3.9 & 5.5 & 7.5 & 38.4 \\
\hline 4 & Share of real estate loans (\%) & 64.3 & 62.1 & 56.4 & 53.9 & 47.3 & 11.1 & 1.4 & 57.5 & 64.8 & 71.9 & 91.9 \\
\hline 5 & Non-interest income to asset ratio (\%) & 1.1 & 1.2 & 1.4 & 1.4 & 1.5 & 0.8 & 0.0 & 0.8 & 1.0 & 1.3 & 25.3 \\
\hline \multicolumn{13}{|c|}{ Performance } \\
\hline 1 & Common Equity Tier 1 ratio (\%) & 14.6 & 14.3 & 13.1 & 13.1 & 13.6 & 3.9 & 5.8 & 12.2 & 13.4 & 15.8 & 52.9 \\
\hline 2 & Leverage ratio (\%) & 10.2 & 9.9 & 9.5 & 9.4 & 9.5 & 1.5 & 4.4 & 9.3 & 9.9 & 10.8 & 24.1 \\
\hline 3 & Efficiency Ratio (\%) (3) & 64.2 & 62.1 & 61.3 & 60.7 & 58.7 & 7.2 & 19.5 & 59.9 & 63.9 & 68.4 & 109.6 \\
\hline 4 & Pretax Return on Assets (\%) & 1.4 & 1.5 & 1.4 & 1.4 & 1.5 & 0.5 & -1.0 & 1.2 & 1.4 & 1.6 & 19.9 \\
\hline 5 & Net Interest Margin (\%) & 3.6 & 3.5 & 3.1 & 3.1 & 3.1 & 0.6 & 1.7 & 3.2 & 3.5 & 3.8 & 18.6 \\
\hline 6 & Non-performing assets ratio (\%) & 1.0 & 0.9 & 0.9 & 0.9 & 0.9 & 0.9 & 0.0 & 0.6 & 0.9 & 1.1 & 10.9 \\
\hline
\end{tabular}

Summary statistics: 2017

\begin{tabular}{|c|c|c|c|c|c|c|c|c|c|c|c|c|}
\hline & \multirow[b]{2}{*}{ Variable } & \multicolumn{5}{|c|}{ mean (1) } & \multirow{2}{*}{ sd } & \multirow{2}{*}{$\min$} & \multirow{2}{*}{ p25 } & \multirow{2}{*}{ p50 } & \multirow{2}{*}{ p75 } & \multirow{2}{*}{$\max$} \\
\hline & & simple & land & pop. & GDP & asset & & & & & & \\
\hline \multicolumn{13}{|c|}{ Structure } \\
\hline 1 & Number of banks & 8.2 & 7.7 & 28.9 & 35.1 & 40.6 & 8.3 & 1.0 & 3.0 & 6.0 & 10.0 & 110.0 \\
\hline 2 & Number of counties a bank operates in (2) & 4.6 & n.a. & n.a. & n.a. & n.a. & 22.7 & 1.0 & 1.0 & 2.0 & 3.0 & 925.0 \\
\hline 3 & Share of the largest bank by assets (\%) & 44.3 & 47.6 & 30.7 & 31.4 & 37.9 & 21.2 & 11.8 & 28.4 & 39.4 & 54.3 & 100.0 \\
\hline 4 & Share of community banks by assets (\%) & 55.3 & 48.1 & 22.9 & 18.8 & 12.7 & 34.6 & 0.0 & 23.5 & 57.4 & 88.7 & 100.0 \\
\hline 5 & Share of top 5 US banks by assets (\%) & 12.0 & 24.8 & 34.5 & 38.8 & 43.0 & 18.6 & 0.0 & 0.0 & 0.0 & 19.3 & 100.0 \\
\hline 6 & Per capita deposits (\$ Thou.) & 22.3 & 20.8 & 36.1 & 65.6 & 313.0 & 53.8 & 0.7 & 12.5 & 17.3 & 24.7 & 2718.3 \\
\hline 7 & Deposits to GDP ratio (\%) & 51.2 & 45.1 & 52.8 & 60.6 & 287.1 & 61.9 & 0.5 & 33.6 & 45.6 & 61.0 & 2913.5 \\
\hline 8 & Per capita assets (\$ Thou.) & 29.5 & 27.4 & 53.2 & 102.8 & 577.2 & 106.0 & 0.8 & 15.7 & 21.7 & 31.2 & 5576.3 \\
\hline 9 & Assets to GDP ratio (\%) & 65.9 & 58.4 & 74.7 & 89.3 & 530.6 & 116.8 & 0.8 & 43.1 & 57.9 & 76.6 & 5976.9 \\
\hline \multicolumn{13}{|c|}{ Business model } \\
\hline 1 & Share of agricultural loans (\%) & 5.8 & 5.5 & 1.2 & 1.0 & 0.7 & 9.4 & 0.0 & 0.3 & 1.4 & 7.0 & 84.0 \\
\hline 2 & Share of commercial and industrial loans (\%) & 15.8 & 16.8 & 20.3 & 21.1 & 20.7 & 5.4 & 0.2 & 11.7 & 15.5 & 19.5 & 43.8 \\
\hline 3 & Share of commercial and industrial loans below $\$ 1$ mio (\%) & 6.0 & 5.8 & 3.9 & 3.5 & 3.1 & 3.1 & 0.0 & 3.9 & 5.4 & 7.4 & 26.0 \\
\hline 4 & Share of real estate loans (\%) & 64.5 & 62.4 & 56.2 & 53.6 & 47.0 & 11.0 & 2.6 & 57.5 & 64.7 & 72.2 & 91.7 \\
\hline 5 & Non-interest income to asset ratio (\%) & 1.1 & 1.1 & 1.4 & 1.4 & 1.5 & 0.8 & 0.0 & 0.8 & 1.0 & 1.3 & 28.8 \\
\hline \multicolumn{13}{|c|}{ Performance } \\
\hline 1 & Common Equity Tier 1 ratio (\%) & 14.7 & 14.6 & 13.4 & 13.4 & 13.9 & 3.9 & 6.8 & 12.3 & 13.5 & 15.8 & 57.3 \\
\hline 2 & Leverage ratio (\%) & 10.3 & 10.1 & 9.7 & 9.6 & 9.6 & 1.5 & 5.1 & 9.4 & 10.0 & 10.8 & 25.1 \\
\hline 3 & Efficiency Ratio (\%) (3) & 63.4 & 62.4 & 60.9 & 60.3 & 58.2 & 6.8 & -12.1 & 59.7 & 63.0 & 66.7 & 104.0 \\
\hline 4 & Pretax Return on Assets (\%) & 1.4 & 1.5 & 1.5 & 1.5 & 1.6 & 0.5 & -3.1 & 1.2 & 1.4 & 1.6 & 21.9 \\
\hline 5 & Net Interest Margin (\%) & 3.6 & 3.5 & 3.2 & 3.2 & 3.3 & 0.6 & 0.8 & 3.3 & 3.6 & 3.9 & 18.8 \\
\hline 6 & Non-performing assets ratio (\%) & 0.9 & 0.8 & 0.8 & 0.7 & 0.7 & 1.0 & 0.0 & 0.6 & 0.7 & 1.0 & 8.4 \\
\hline
\end{tabular}




\begin{tabular}{|c|c|c|c|c|c|c|c|c|c|c|c|c|}
\hline & \multirow[b]{2}{*}{ Variable } & \multicolumn{5}{|c|}{ mean (1) } & \multirow{2}{*}{ sd } & \multirow{2}{*}{$\min$} & \multirow{2}{*}{ p25 } & \multirow{2}{*}{ p50 } & \multirow{2}{*}{ p75 } & \multirow{2}{*}{$\max$} \\
\hline & & simple & land & pop. & GDP & asset & & & & & & \\
\hline \multicolumn{13}{|c|}{ Structure } \\
\hline 1 & Number of banks & 8.1 & 7.6 & 28.5 & 34.8 & 40.4 & 8.2 & 1.0 & 3.0 & 6.0 & 10.0 & 105.0 \\
\hline 2 & Number of counties a bank operates in (2) & 4.8 & n.a. & n.a. & n.a. & n.a. & 23.1 & 1.0 & 1.0 & 2.0 & 3.0 & 908.0 \\
\hline 3 & Share of the largest bank by assets (\%) & 44.6 & 47.7 & 30.7 & 31.3 & 37.7 & 21.4 & 11.8 & 28.7 & 39.5 & 54.4 & 100.0 \\
\hline 4 & Share of community banks by assets (\%) & 54.9 & 48.2 & 22.6 & 18.7 & 12.6 & 34.9 & 0.0 & 22.3 & 56.7 & 88.8 & 100.0 \\
\hline 5 & Share of top 5 US banks by assets (\%) & 11.7 & 24.2 & 33.8 & 38.1 & 42.1 & 18.3 & 0.0 & 0.0 & 0.0 & 18.7 & 100.0 \\
\hline 6 & Per capita deposits (\$ Thou.) & 22.8 & 20.8 & 37.3 & 67.4 & 344.5 & 59.1 & 1.0 & 12.8 & 17.6 & 25.1 & 3039.8 \\
\hline 7 & Deposits to GDP ratio (\%) & 50.0 & 43.3 & 52.1 & 59.6 & 302.7 & 63.0 & 0.5 & 32.9 & 44.4 & 59.8 & 3040.8 \\
\hline 8 & Per capita assets (\$ Thou.) & 30.1 & 27.3 & 54.5 & 104.9 & 625.2 & 113.7 & 1.1 & 16.1 & 22.1 & 31.8 & 6030.6 \\
\hline 9 & Assets to GDP ratio $(\%)$ & 64.3 & 55.9 & 73.4 & 87.3 & 549.2 & 117.0 & 0.7 & 41.8 & 56.5 & 75.2 & 6032.7 \\
\hline \multicolumn{13}{|c|}{ Business model } \\
\hline 1 & Share of agricultural loans (\%) & 5.7 & 5.5 & 1.1 & 1.0 & 0.7 & 9.2 & 0.0 & 0.3 & 1.4 & 6.8 & 82.7 \\
\hline 2 & Share of commercial and industrial loans (\%) & 16.4 & 17.4 & 21.1 & 21.8 & 21.3 & 5.7 & 0.3 & 12.1 & 15.9 & 20.3 & 46.8 \\
\hline 3 & Share of commercial and industrial loans below $\$ 1 \mathrm{mio}(\%)$ & 6.0 & 5.8 & 3.8 & 3.5 & 3.1 & 3.1 & 0.3 & 3.9 & 5.4 & 7.3 & 25.6 \\
\hline 4 & Share of real estate loans (\%) & 64.1 & 62.0 & 55.4 & 52.7 & 45.9 & 11.1 & 3.5 & 56.5 & 64.3 & 72.1 & 91.6 \\
\hline 5 & Non-interest income to asset ratio (\%) & 1.0 & 1.1 & 1.3 & 1.4 & 1.5 & 0.6 & -0.1 & 0.7 & 1.0 & 1.3 & 25.2 \\
\hline \multicolumn{13}{|c|}{ Performance } \\
\hline 1 & Common Equity Tier 1 ratio (\%) & 14.7 & 14.7 & 13.3 & 13.3 & 13.8 & 4.0 & 7.8 & 12.4 & 13.5 & 15.8 & 54.5 \\
\hline 2 & Leverage ratio $(\%)$ & 10.5 & 10.3 & 9.7 & 9.6 & 9.7 & 1.5 & 5.8 & 9.5 & 10.1 & 11.0 & 24.8 \\
\hline 3 & Efficiency Ratio (\%) (3) & 61.6 & 60.8 & 58.7 & 58.1 & 56.1 & 6.6 & 22.5 & 57.5 & 61.0 & 65.3 & 108.8 \\
\hline 4 & Pretax Return on Assets (\%) & 1.5 & 1.6 & 1.6 & 1.6 & 1.7 & 0.5 & -3.4 & 1.4 & 1.6 & 1.7 & 21.1 \\
\hline 5 & Net Interest Margin (\%) & 3.8 & 3.7 & 3.4 & 3.3 & 3.4 & 0.6 & 2.1 & 3.5 & 3.7 & 4.0 & 19.0 \\
\hline 6 & Non-performing assets ratio (\%) & 0.8 & 0.7 & 0.6 & 0.6 & 0.6 & 0.8 & 0.0 & 0.5 & 0.6 & 0.9 & 9.0 \\
\hline
\end{tabular}

\section{Summary statistics: 2019}

\begin{tabular}{|c|c|c|c|c|c|c|c|c|c|c|c|c|}
\hline & \multirow[b]{2}{*}{ Variable } & \multicolumn{5}{|c|}{ mean (1) } & \multirow{2}{*}{ sd } & \multirow{2}{*}{$\min$} & \multirow{2}{*}{ p25 } & \multirow{2}{*}{ p50 } & \multirow{2}{*}{ p75 } & \multirow{2}{*}{$\max$} \\
\hline & & simple & land & pop. & GDP & asset & & & & & & \\
\hline \multicolumn{13}{|c|}{ Structure } \\
\hline 1 & Number of banks & 8.0 & 7.6 & 28.2 & 34.5 & 40.2 & 8.2 & 1.0 & 3.0 & 6.0 & 10.0 & 104.0 \\
\hline 2 & Number of counties a bank operates in (2) & 4.9 & n.a. & n.a. & n.a. & n.a. & 23.3 & 1.0 & 1.0 & 2.0 & 4.0 & 870.0 \\
\hline 3 & Share of the largest bank by assets (\%) & 45.1 & 48.1 & 31.0 & 31.5 & 38.0 & 21.5 & 11.5 & 28.9 & 40.1 & 55.0 & 100.0 \\
\hline 4 & Share of community banks by assets (\%) & 54.4 & 48.1 & 21.9 & 18.0 & 11.9 & 35.1 & 0.0 & 21.6 & 56.3 & 88.7 & 100.0 \\
\hline 5 & Share of top 5 US banks by assets (\%) & 11.2 & 23.5 & 33.2 & 37.6 & 42.1 & 17.9 & 0.0 & 0.0 & 0.0 & 17.5 & 100.0 \\
\hline 6 & Per capita deposits (\$ Thou.) & 23.5 & 21.3 & 38.7 & 70.0 & 389.2 & 66.2 & 0.9 & 13.1 & 18.1 & 25.6 & 3456.0 \\
\hline 7 & Deposits to GDP ratio (\%) & 49.3 & 42.5 & 52.0 & 59.7 & 334.7 & 68.1 & 0.6 & 32.2 & 44.0 & 58.4 & 3351.9 \\
\hline 8 & Per capita assets (\$ Thou.) & 31.1 & 28.0 & 56.4 & 109.1 & 698.3 & 124.4 & 1.1 & 16.6 & 22.8 & 32.9 & 6664.0 \\
\hline 9 & Assets to GDP ratio (\%) & 63.8 & 55.3 & 73.2 & 87.2 & 597.9 & 124.8 & 0.8 & 41.5 & 56.2 & 73.8 & 6463.4 \\
\hline \multicolumn{13}{|c|}{ Business model } \\
\hline 1 & Share of agricultural loans (\%) & 5.5 & 5.3 & 1.1 & 0.9 & 0.6 & 9.0 & 0.0 & 0.3 & 1.4 & 6.4 & 75.4 \\
\hline 2 & Share of commercial and industrial loans (\%) & 16.4 & 17.1 & 20.7 & 21.3 & 20.8 & 5.7 & 0.2 & 12.2 & 15.9 & 20.1 & 44.9 \\
\hline 3 & Share of commercial and industrial loans below \$1 mio (\%) & 5.9 & 5.7 & 3.9 & 3.6 & 3.1 & 3.1 & 0.2 & 3.8 & 5.4 & 7.2 & 29.5 \\
\hline 4 & Share of real estate loans (\%) & 63.9 & 62.0 & 54.6 & 51.9 & 45.3 & 11.3 & 3.7 & 56.2 & 64.2 & 72.1 & 91.9 \\
\hline 5 & Non-interest income to asset ratio (\%) & 14.8 & 14.8 & 13.4 & 13.4 & 13.8 & 0.8 & -0.1 & 0.8 & 1.0 & 1.3 & 29.0 \\
\hline \multicolumn{13}{|c|}{ Performance } \\
\hline 1 & Common Equity Tier 1 ratio (\%) & 10.7 & 10.4 & 9.9 & 9.8 & 9.7 & 4.0 & 4.8 & 12.5 & 13.6 & 15.8 & 56.2 \\
\hline 2 & Leverage ratio (\%) & 61.8 & 61.2 & 58.8 & 58.2 & 56.5 & 1.6 & 3.8 & 9.7 & 10.4 & 11.3 & 25.7 \\
\hline 3 & Efficiency Ratio (\%) (3) & 1.5 & 1.5 & 1.6 & 1.6 & 1.6 & 6.5 & 21.2 & 57.9 & 61.2 & 65.2 & 116.6 \\
\hline 4 & Pretax Return on Assets (\%) & 3.7 & 3.7 & 3.4 & 3.3 & 3.3 & 0.5 & -3.9 & 1.4 & 1.5 & 1.7 & 24.0 \\
\hline 5 & Net Interest Margin (\%) & 1.0 & 1.1 & 1.3 & 1.4 & 1.5 & 0.6 & 1.1 & 3.4 & 3.7 & 4.0 & 18.8 \\
\hline 6 & Non-performing assets ratio (\%) & 0.8 & 0.7 & 0.6 & 0.6 & 0.5 & 0.7 & 0.0 & 0.5 & 0.6 & 0.8 & 10.4 \\
\hline
\end{tabular}

$$
\text { Notes: }
$$

(1) Cross-county mean; respectively, unweighted and weighted by land, population, GDP and bank assets.

(2) Mean and distribution for this indicator are calculated across banks, not across counties.

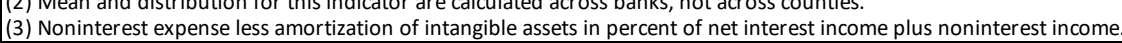




\begin{tabular}{|c|c|c|c|c|c|c|c|c|c|c|c|c|}
\hline & \multicolumn{6}{|c|}{ mean (1) } & \multirow{2}{*}{ sd } & \multirow{2}{*}{$\min$} & \multirow{2}{*}{ p25 } & \multirow{2}{*}{ p50 } & \multirow{2}{*}{ p75 } & \multirow{2}{*}{$\max$} \\
\hline & Variable & simple & land & pop. & GDP & asset & & & & & & \\
\hline \multicolumn{13}{|c|}{ Structure } \\
\hline 1 & Number of banks & 8.0 & 7.6 & n.a. & n.a. & 40.7 & 8.2 & 1.0 & 3.0 & 6.0 & 10.0 & 106.0 \\
\hline 2 & Number of counties a bank operates in (2) & 5.1 & n.a. & n.a. & n.a. & & 23.7 & 1.0 & 1.0 & 2.0 & 4.0 & 857.0 \\
\hline 3 & Share of the largest bank by assets (\%) & 45.5 & 48.4 & n.a. & n.a. & 41.2 & 21.8 & 12.0 & 29.4 & 40.2 & 56.0 & 100.0 \\
\hline 4 & Share of community banks by assets (\%) & 54.3 & 48.3 & n.a. & n.a. & 11.6 & 35.0 & 0.0 & 21.7 & 56.1 & 88.3 & 100.0 \\
\hline 5 & Share of top 5 US banks by assets (\%) & 10.8 & 22.7 & n.a. & n.a. & 42.3 & 17.6 & 0.0 & 0.0 & 0.0 & 16.4 & 100.0 \\
\hline 6 & Per capita deposits (\$ Thou.) & n.a. & n.a. & n.a. & n.a. & n.a. & n.a. & n.a. & n.a. & n.a. & n.a. & n.a. \\
\hline 7 & Deposits to GDP ratio (\%) & n.a. & n.a. & n.a. & n.a. & n.a. & n.a. & n.a. & n.a. & n.a. & n.a. & n.a. \\
\hline 8 & Per capita assets (\$ Thou.) & n.a. & n.a. & n.a. & n.a. & n.a. & n.a. & n.a. & n.a. & n.a. & n.a. & n.a. \\
\hline 9 & Assets to GDP ratio (\%) & n.a. & n.a. & n.a. & n.a. & n.a. & n.a. & n.a. & n.a. & n.a. & n.a. & n.a. \\
\hline \multicolumn{13}{|c|}{ Business model } \\
\hline 1 & Share of agricultural loans (\%) & 4.9 & 4.7 & n.a. & n.a. & 0.5 & 8.3 & 0.0 & 0.3 & 1.2 & 5.6 & 72.4 \\
\hline 2 & Share of commercial and industrial loans (\%) & 19.3 & 20.1 & n.a. & n.a. & 21.9 & 5.8 & 0.9 & 15.3 & 19.1 & 22.9 & 51.4 \\
\hline 3 & Share of commercial and industrial loans below $\$ 1$ mio (\%) & 8.2 & 8.1 & n.a. & n.a. & 4.5 & 3.3 & 0.5 & 5.9 & 7.6 & 9.5 & 33.1 \\
\hline 4 & Share of real estate loans (\%) & 62.1 & 60.1 & n.a. & n.a. & 43.8 & 10.7 & 4.9 & 54.6 & 62.4 & 69.8 & 90.7 \\
\hline 5 & Non-interest income to asset ratio (\%) & 1.1 & 1.1 & n.a. & n.a. & 1.4 & 0.9 & -0.2 & 0.7 & 1.0 & 1.2 & 21.1 \\
\hline \multicolumn{13}{|c|}{ Performance } \\
\hline 1 & Common Equity Tier 1 ratio (\%) & 11.7 & 12.2 & n.a. & n.a. & 14.0 & 4.4 & 0.3 & 9.6 & 12.1 & 13.6 & 45.8 \\
\hline 2 & Leverage ratio (\%) & 9.8 & 9.6 & n.a. & n.a. & 8.8 & 1.5 & 5.5 & 8.8 & 9.4 & 10.3 & 28.9 \\
\hline 3 & Efficiency Ratio (\%) (3) & 62.6 & 63.3 & n.a. & n.a. & 59.8 & 6.6 & 28.1 & 59.1 & 62.1 & 65.7 & 131.1 \\
\hline 4 & Pretax Return on Assets (\%) & 1.1 & 1.0 & n.a. & n.a. & 0.9 & 0.6 & -5.5 & 0.9 & 1.2 & 1.4 & 17.9 \\
\hline 5 & Net Interest Margin (\%) & 3.4 & 3.3 & n.a. & n.a. & 2.8 & 0.5 & 0.6 & 3.1 & 3.4 & 3.6 & 16.7 \\
\hline 6 & Non-performing assets ratio (\%) & 0.7 & 0.7 & n.a. & n.a. & 0.6 & 0.7 & 0.0 & 0.4 & 0.6 & 0.8 & 11.5 \\
\hline
\end{tabular}




\section{Annex 2 - Summay statistics (time charts)}

\section{Structure}

Figure I.1 Number of banks
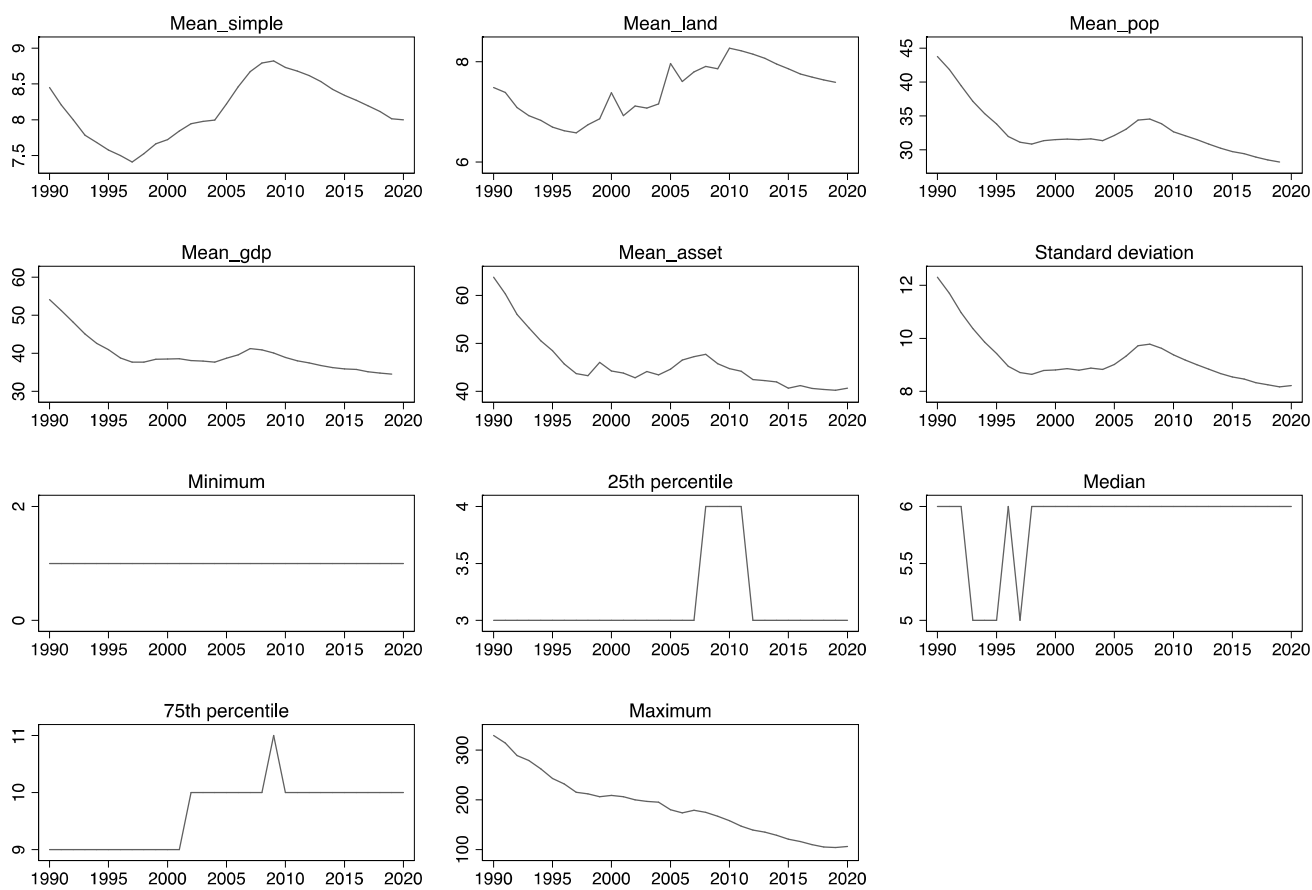

Note: Mean_simple is unweighted mean across counties. Mean_land, Mean_pop, Mean_gdp and Mean_asset are means weighted by land, population, GDP and bank assets respectively.

Figure I.2 Number of counties a bank operates in
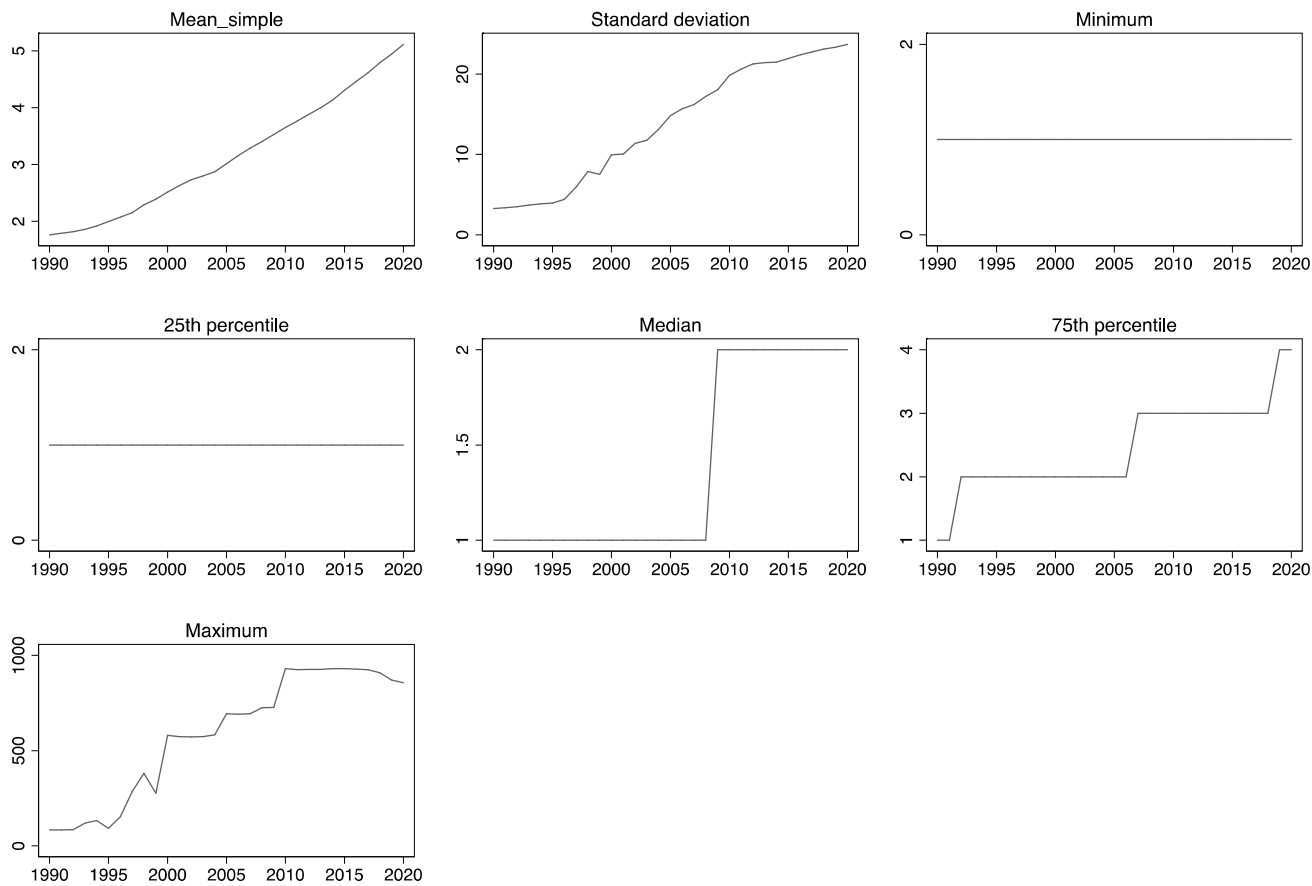

Note: Mean and distribution for this indicator are calculated across banks, not across counties. All other indicators are calculated across counties. 
Figure I.3 Share of the largest bank by assets (\%)
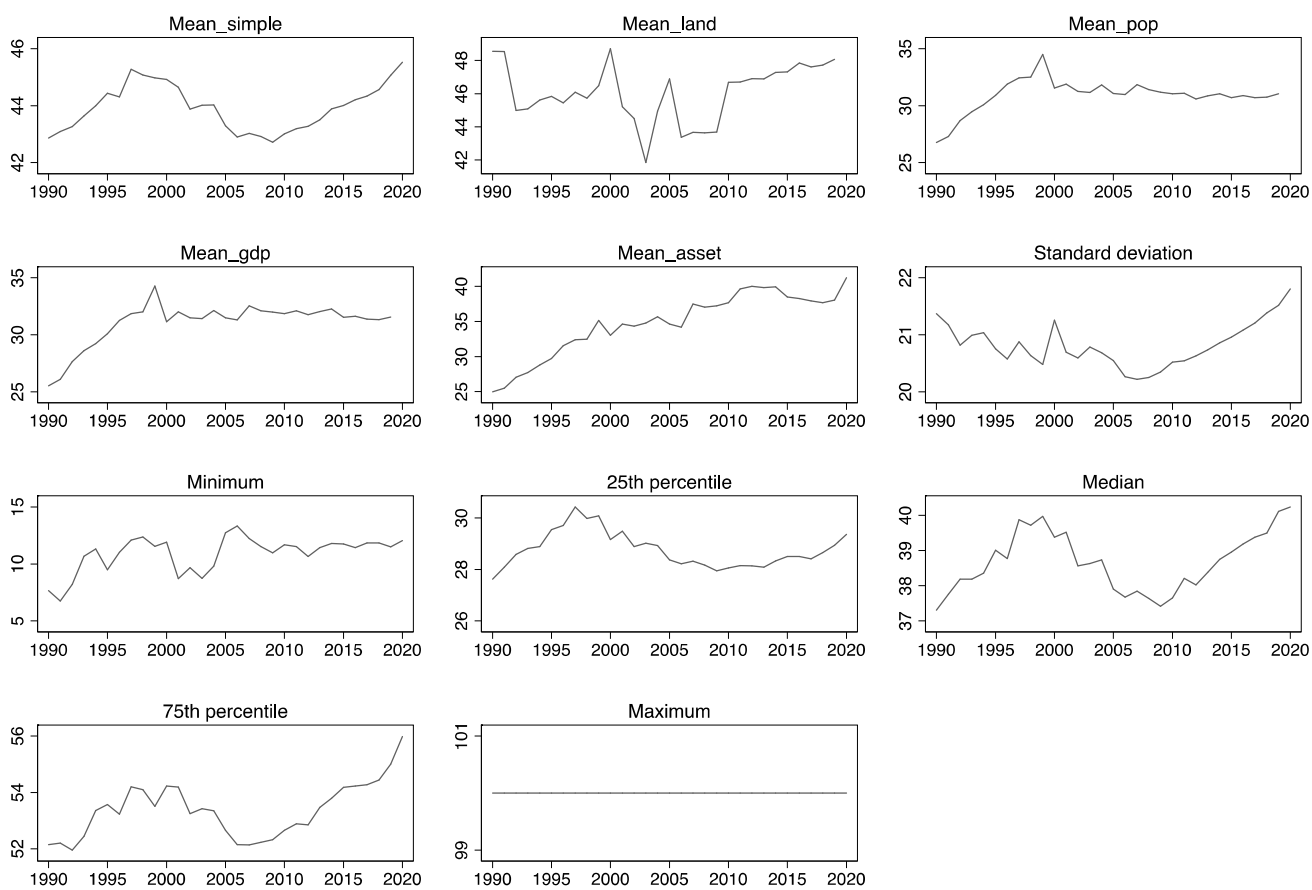

Figure I.4 Share of community banks by assets (\%)
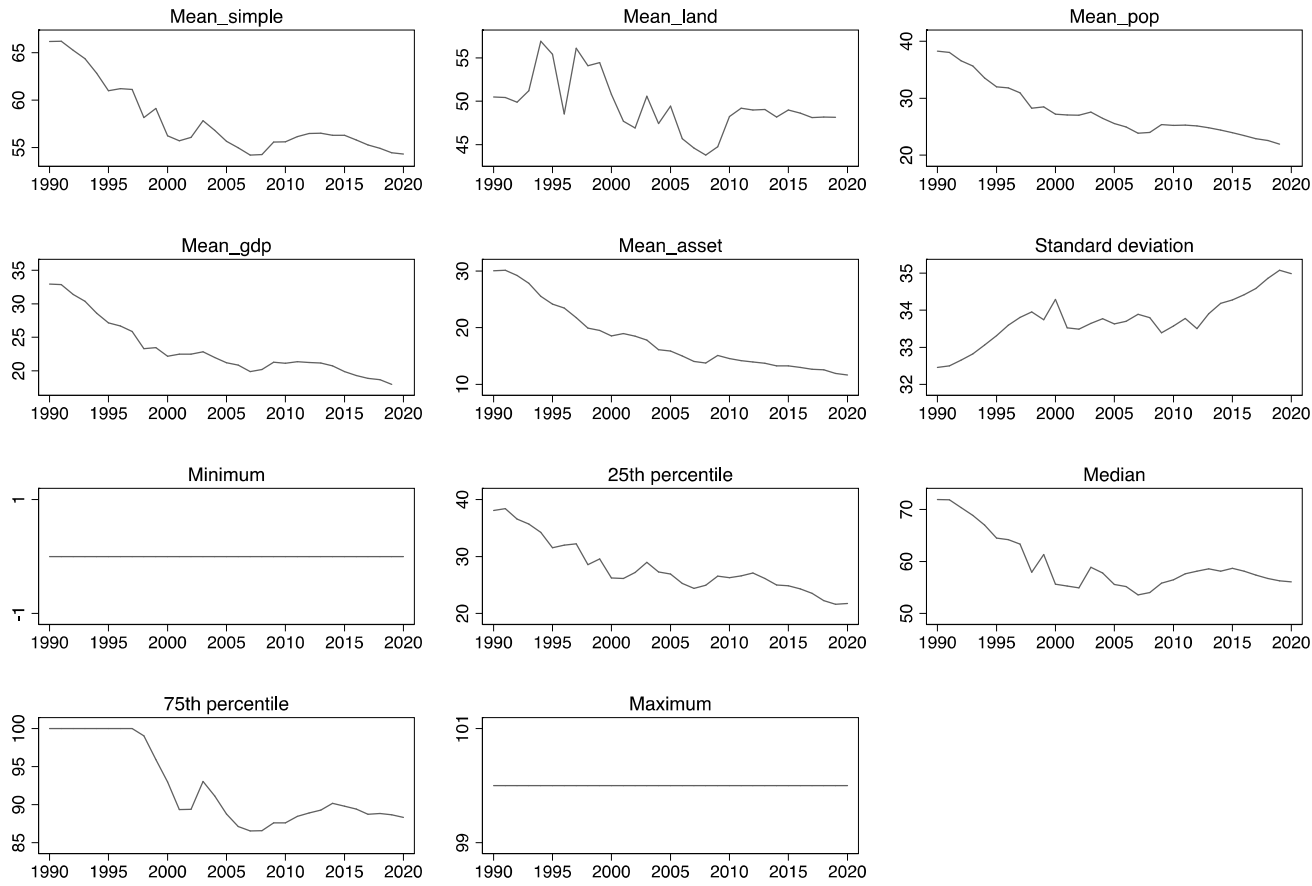
Figure I.5 Share of top 5 US banks by assets (\%)
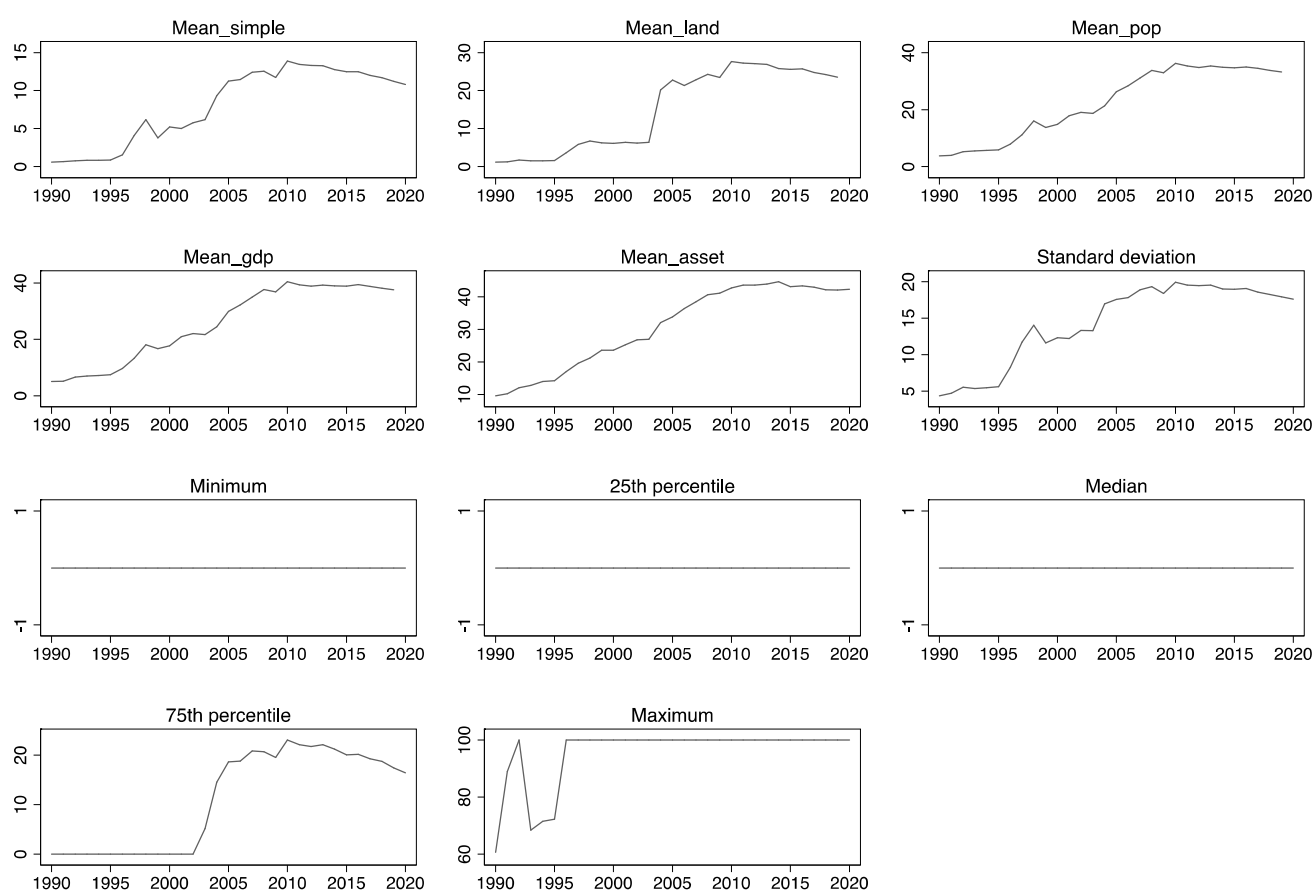

Figure I.6 Per capita deposits (\$ Thou.)
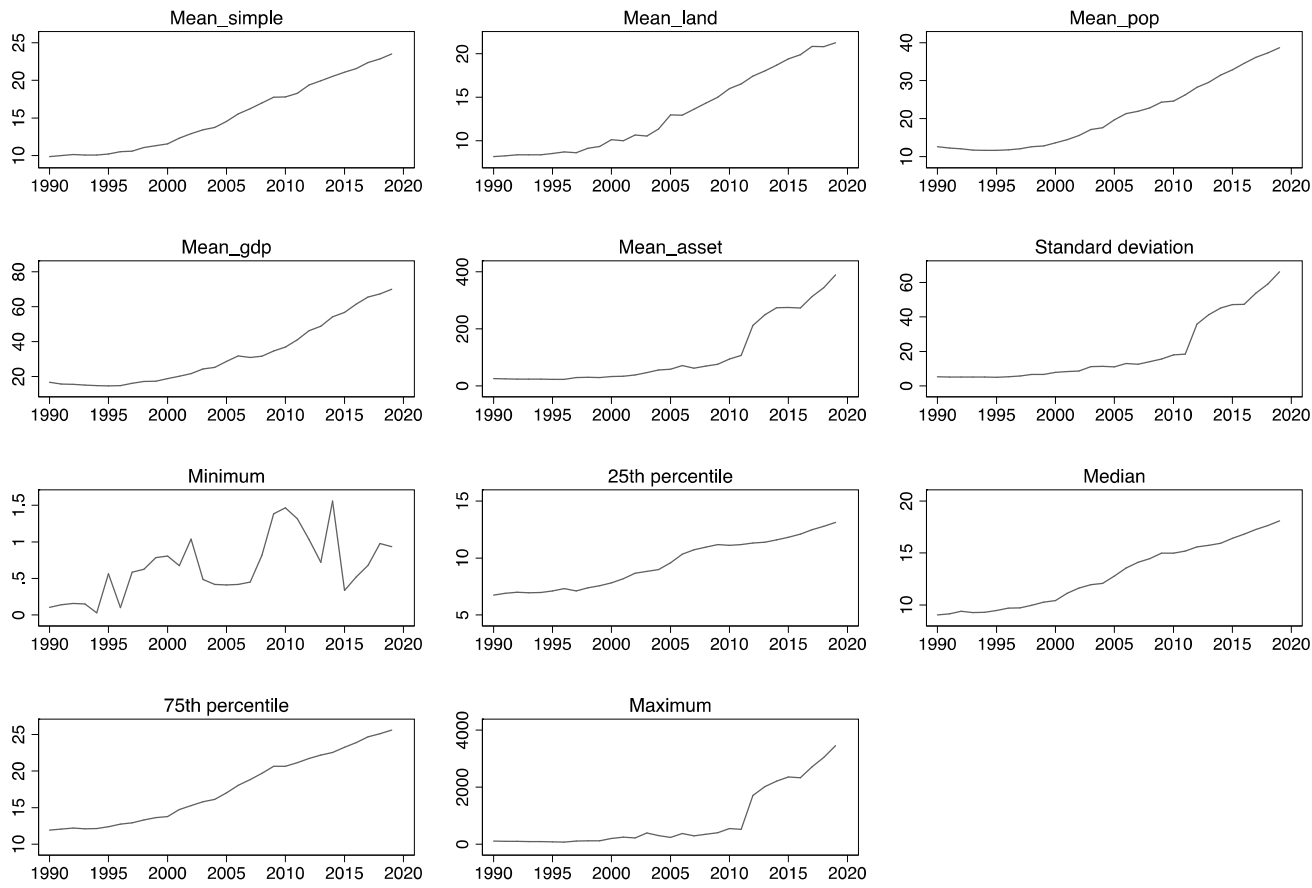
Figure 1.7 Deposits to GDP ratio (\%)
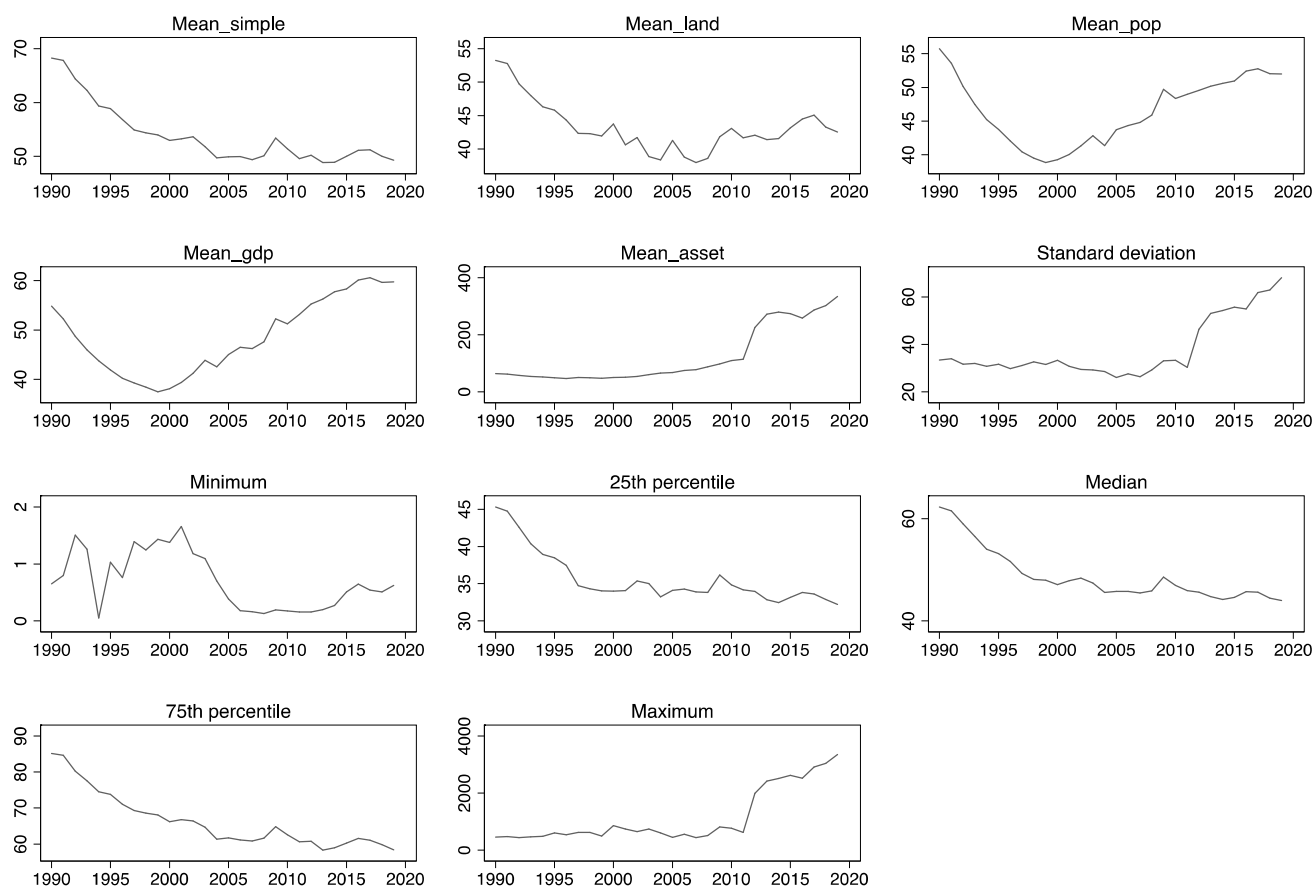

Figure I.8 Per capita assets (\$ Thou.)
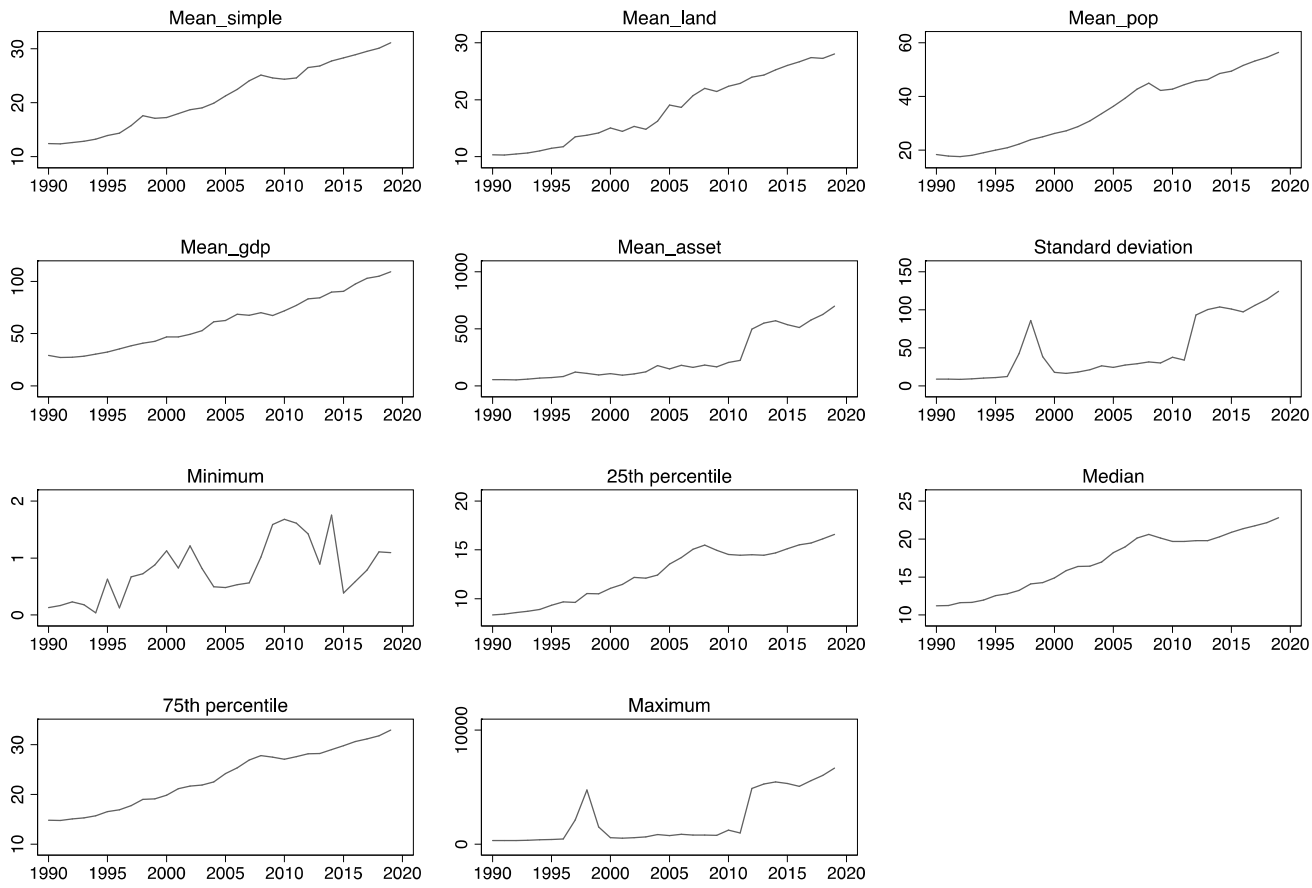
Figure 1.9 Assets to GDP ratio (\%)
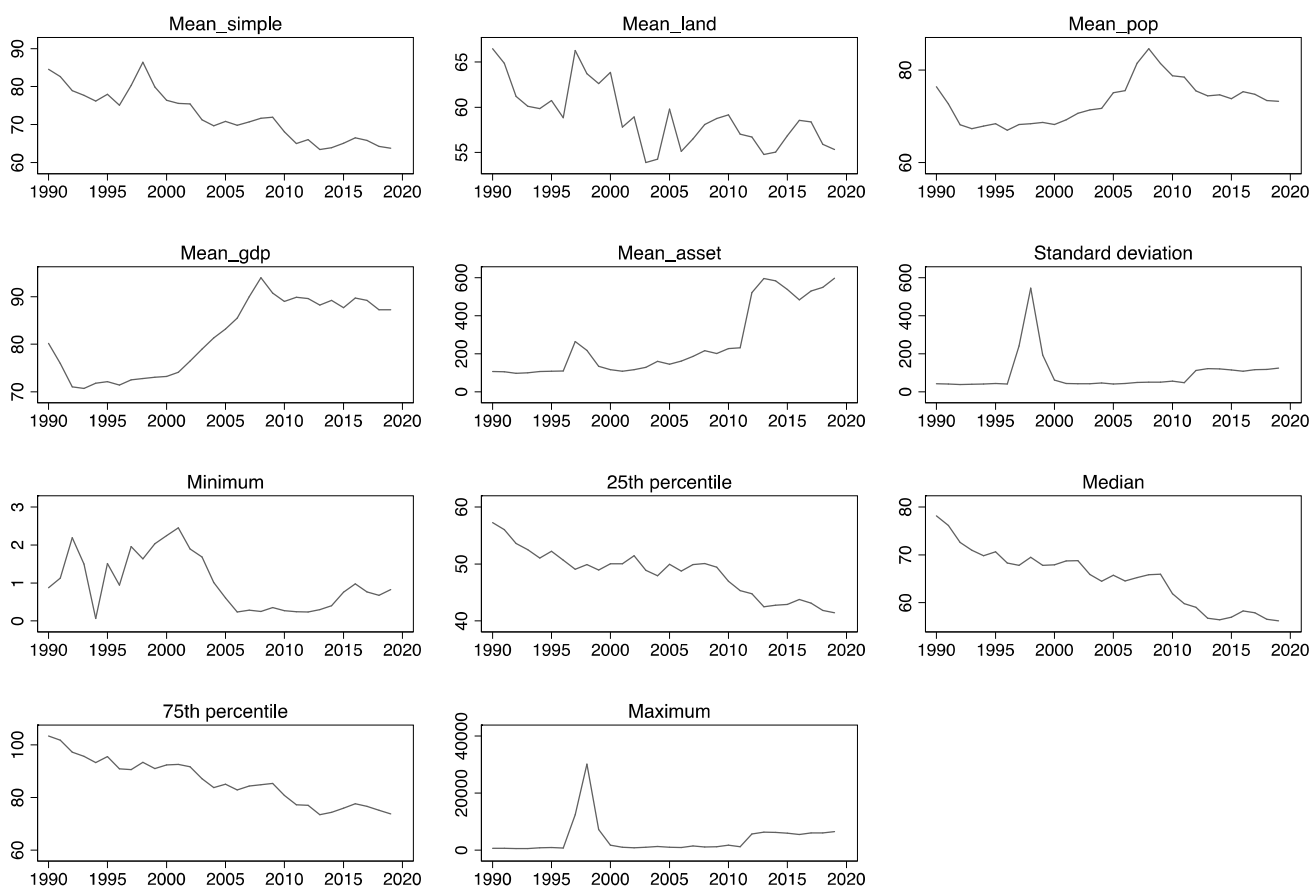

\section{Business models}

Figure II.1 Share of agricultural loans (\%)
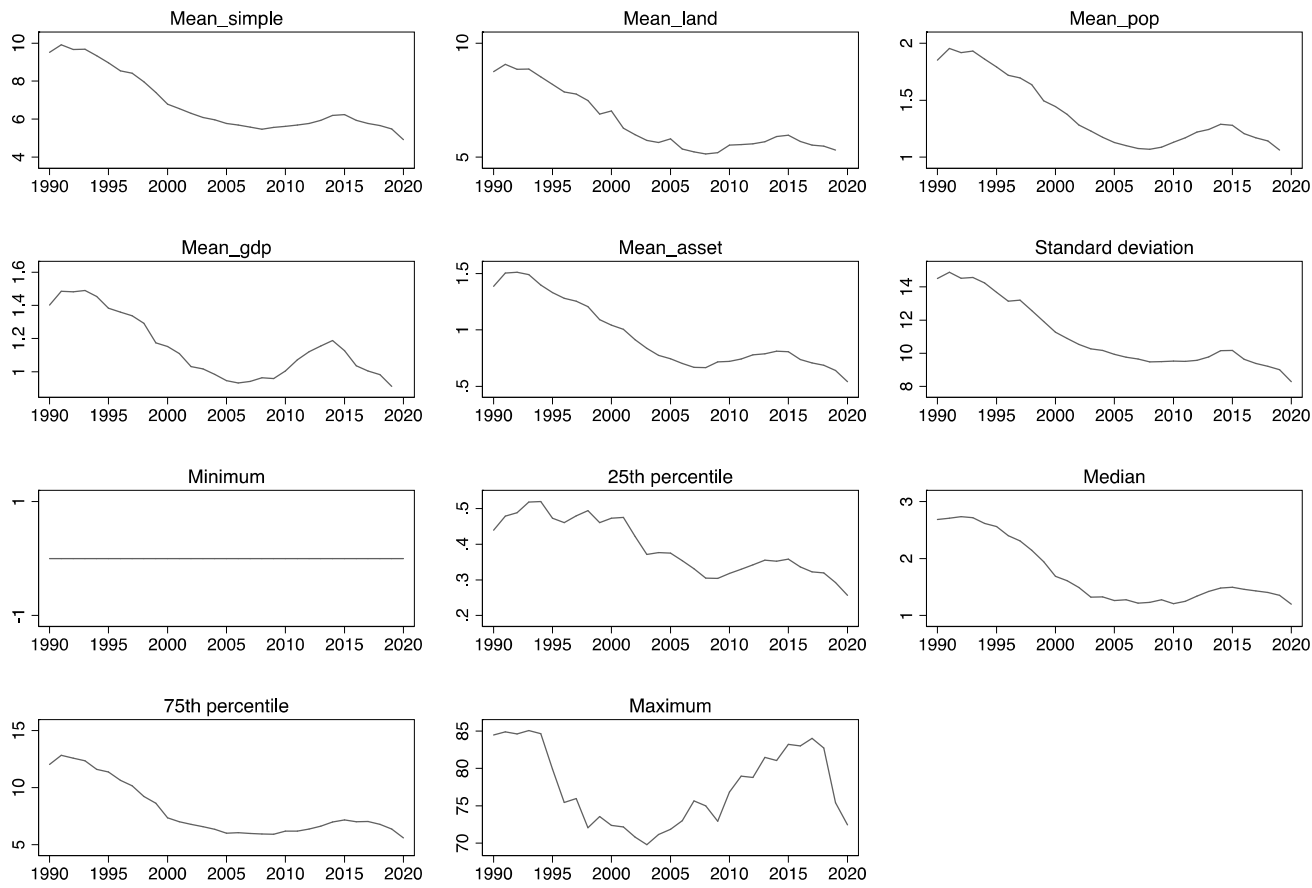
Figure II.2 Share of commercial and industrial loans (\%)
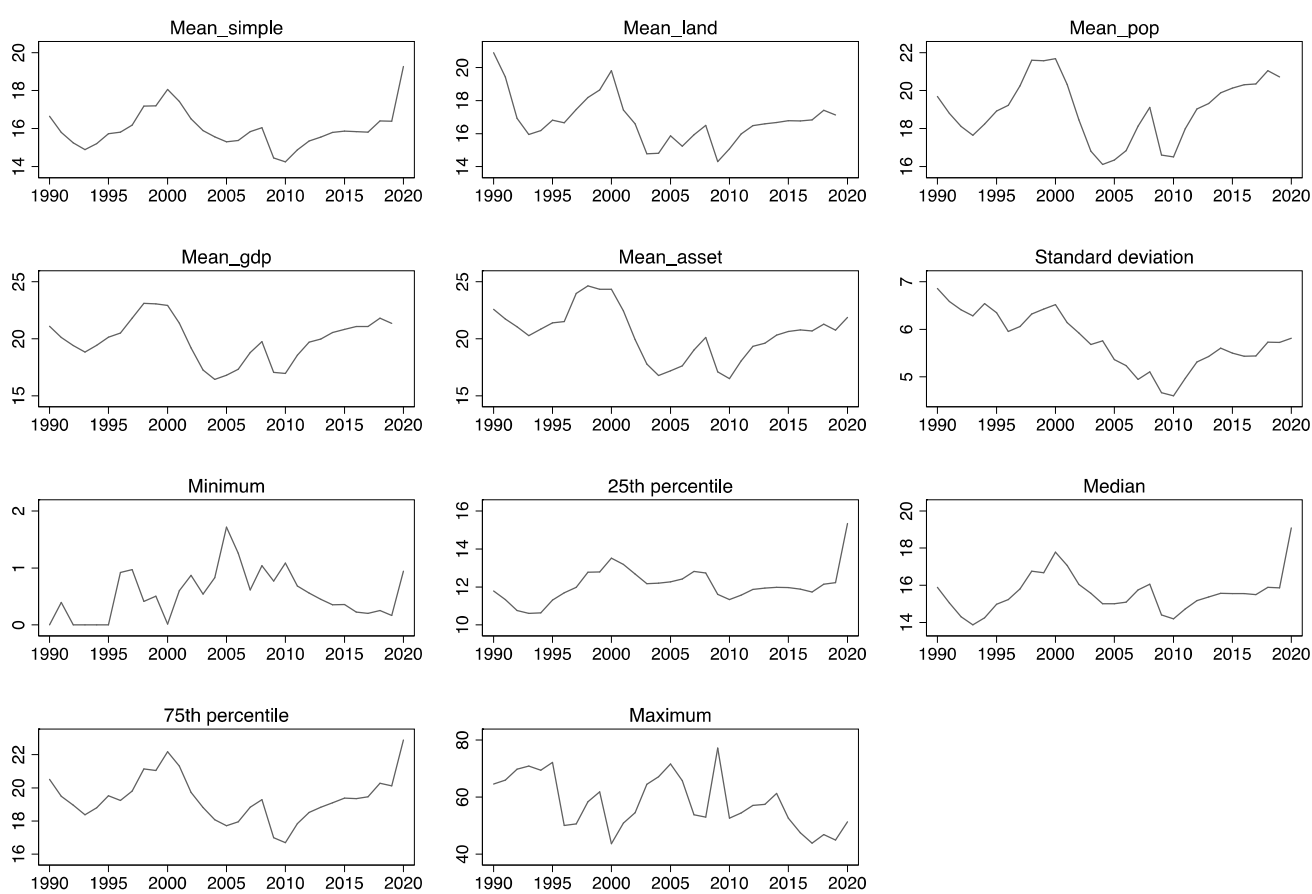

Figure II.3 Share of commercial and industrial loans below \$1 mio (\%)
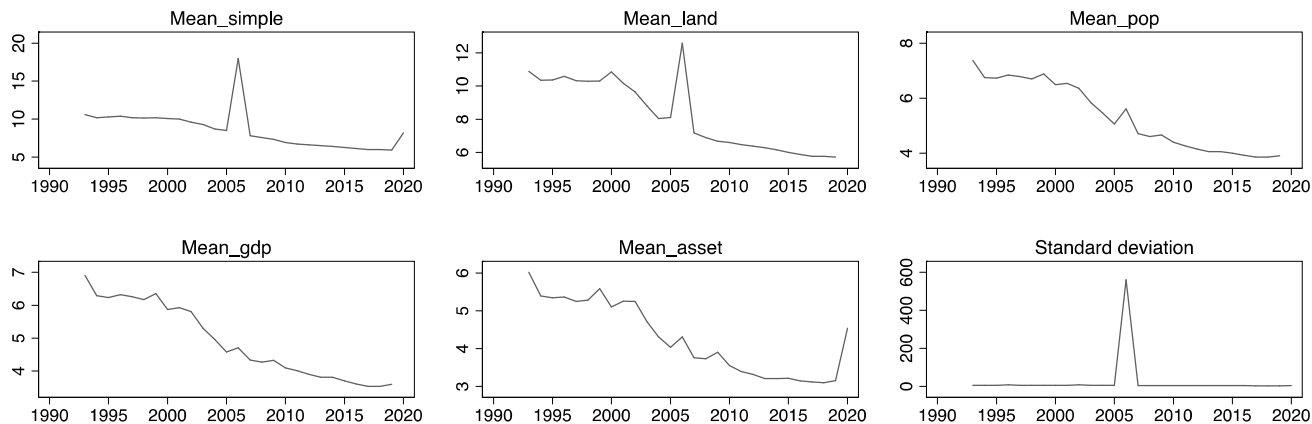

Minimum
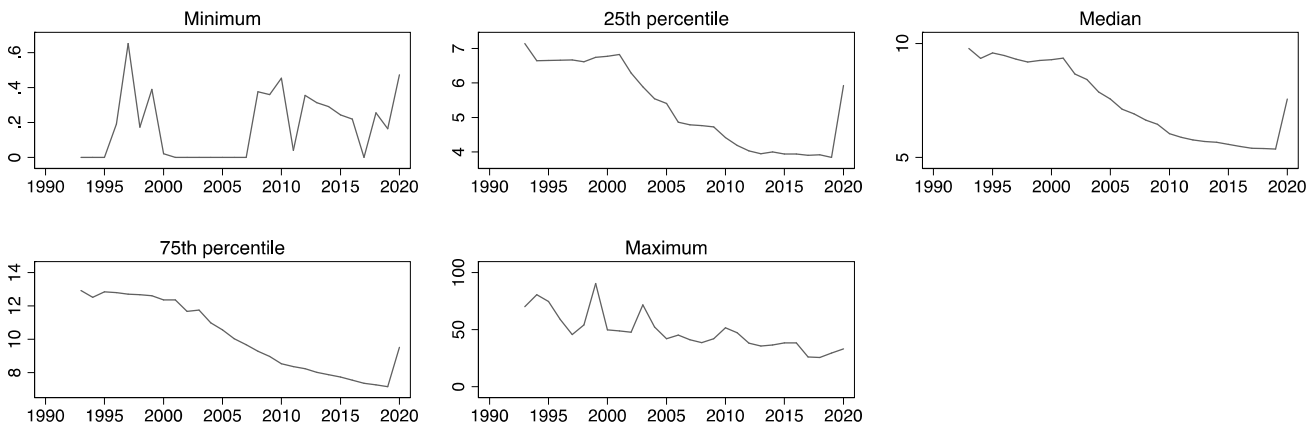

Note: Data for this indicator is available from 1993 onwards. 
Figure II.4 Share of real estate loans (\%)
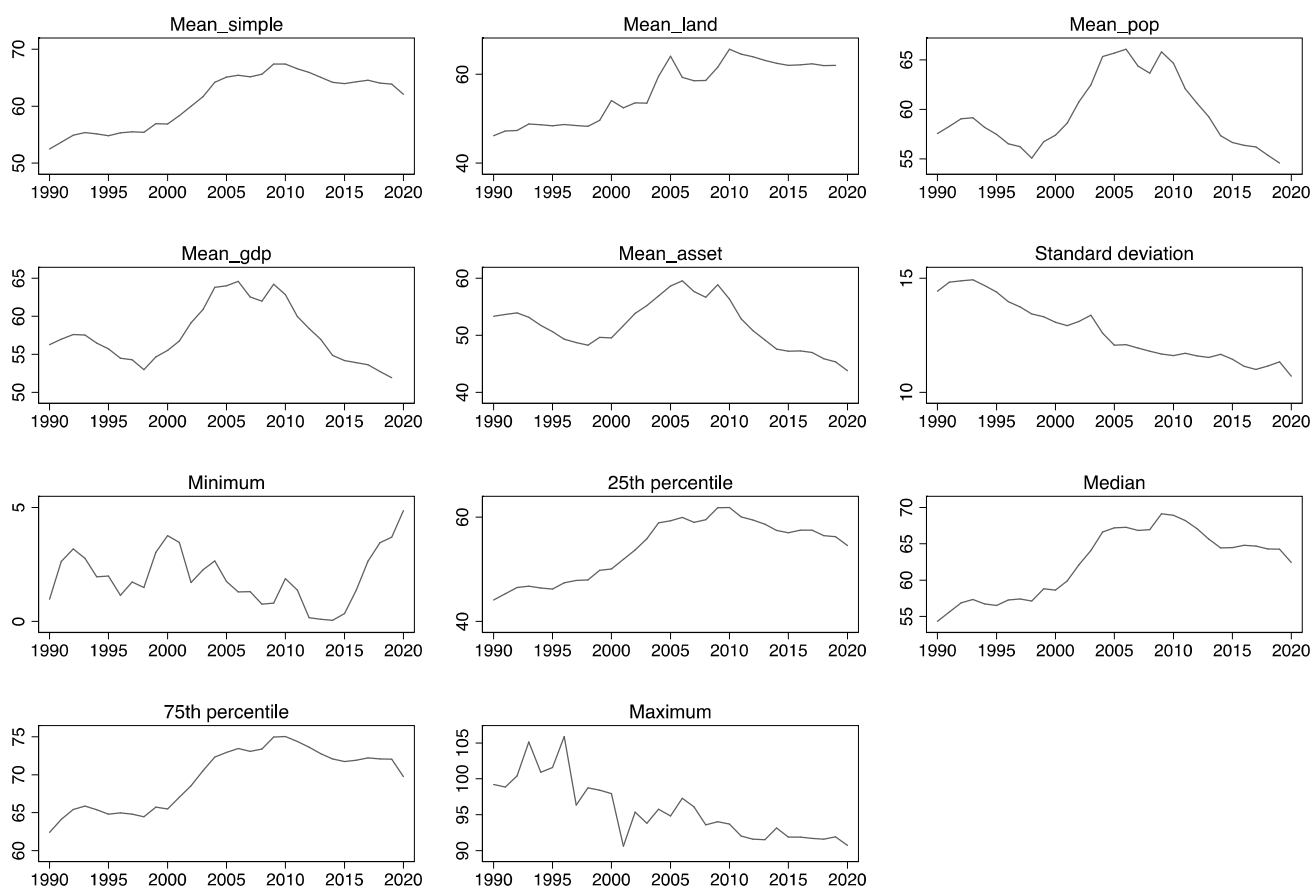

Figure II.5 Non-interest income to asset ratio (\%)
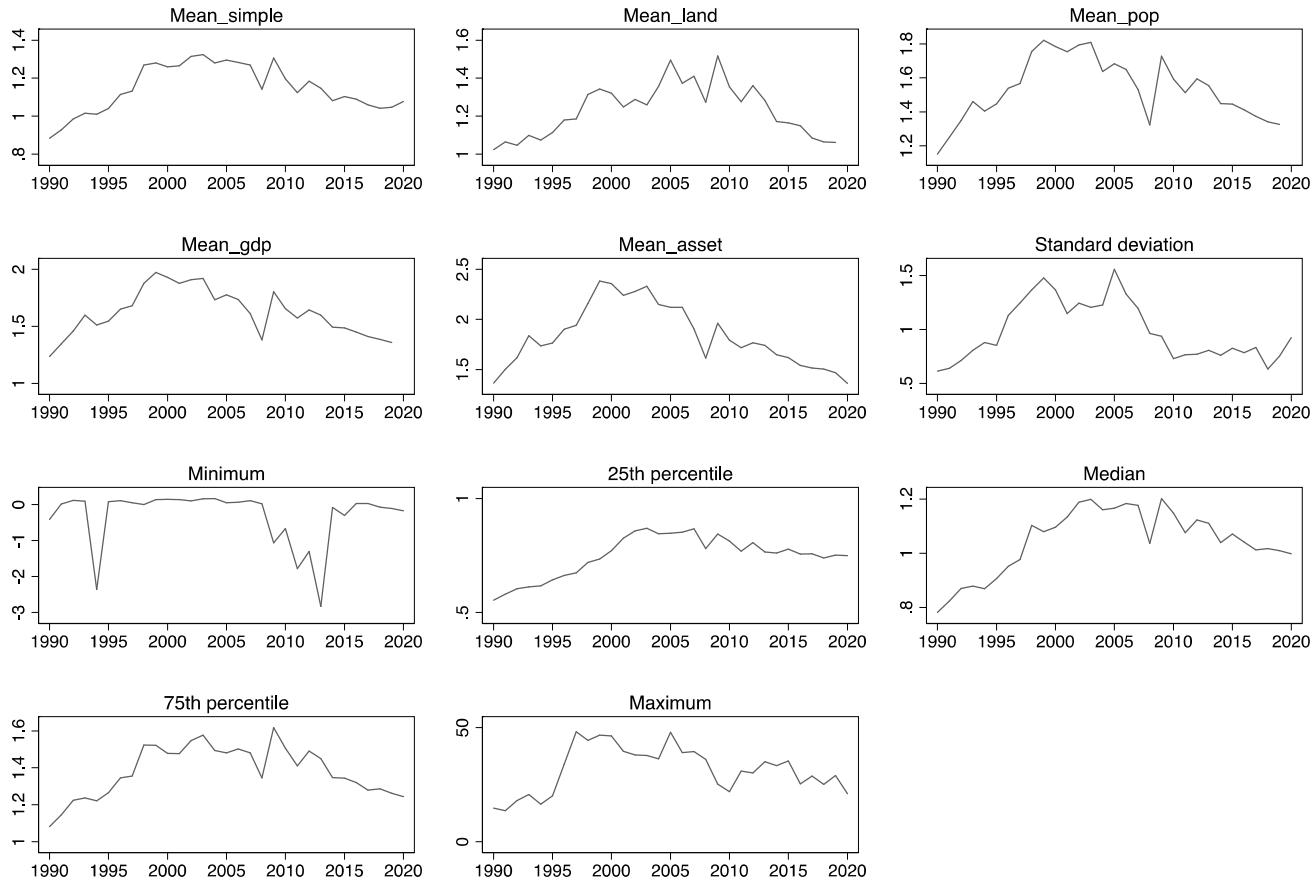


\section{Performance}

Figure III.1 Common Equity Tier 1 ratio (\%)
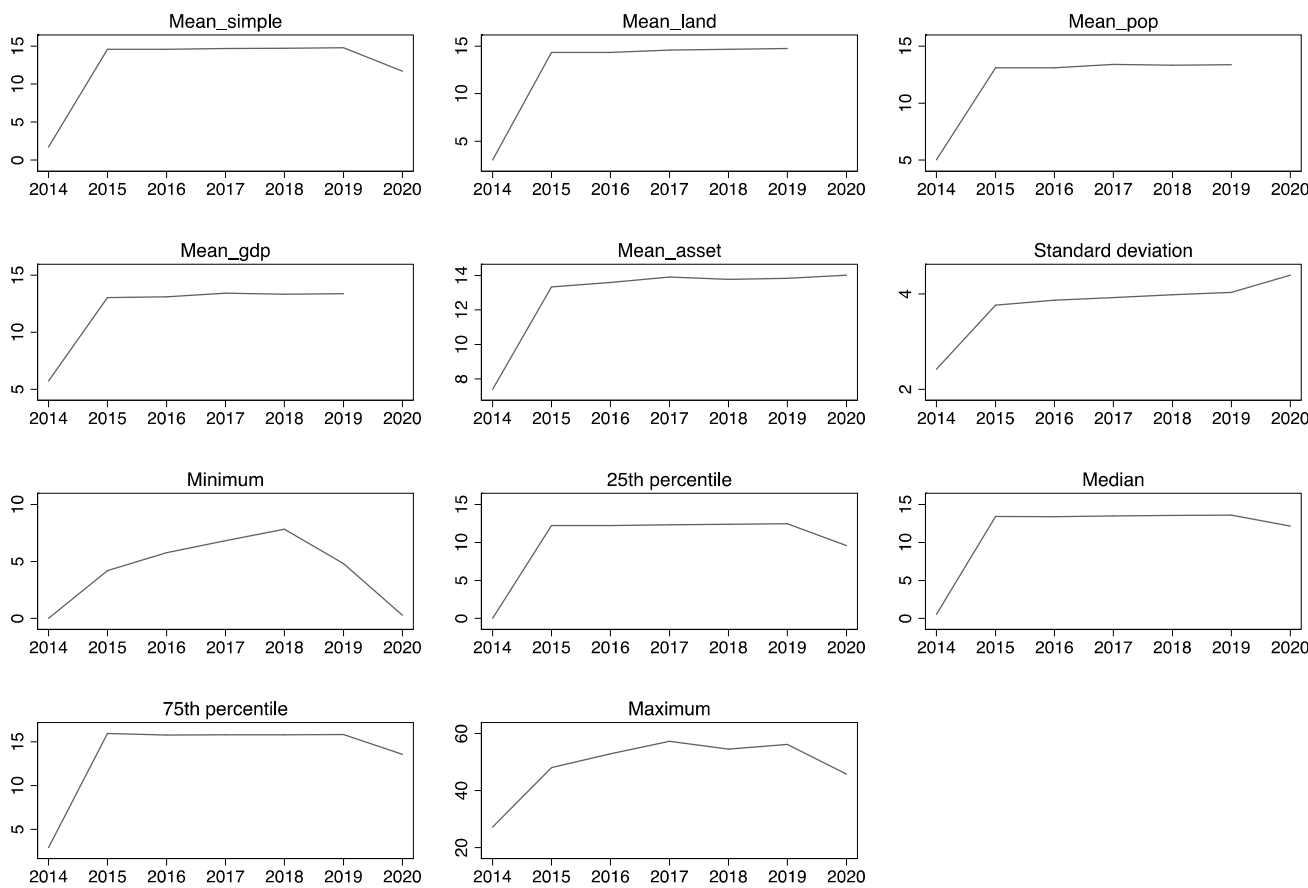

Note: Data for common equity tier 1 ratio is not available prior to 2014, and not available for CBLR-electing institutions starting in 2020.

Figure III.2 Leverage ratio (\%)
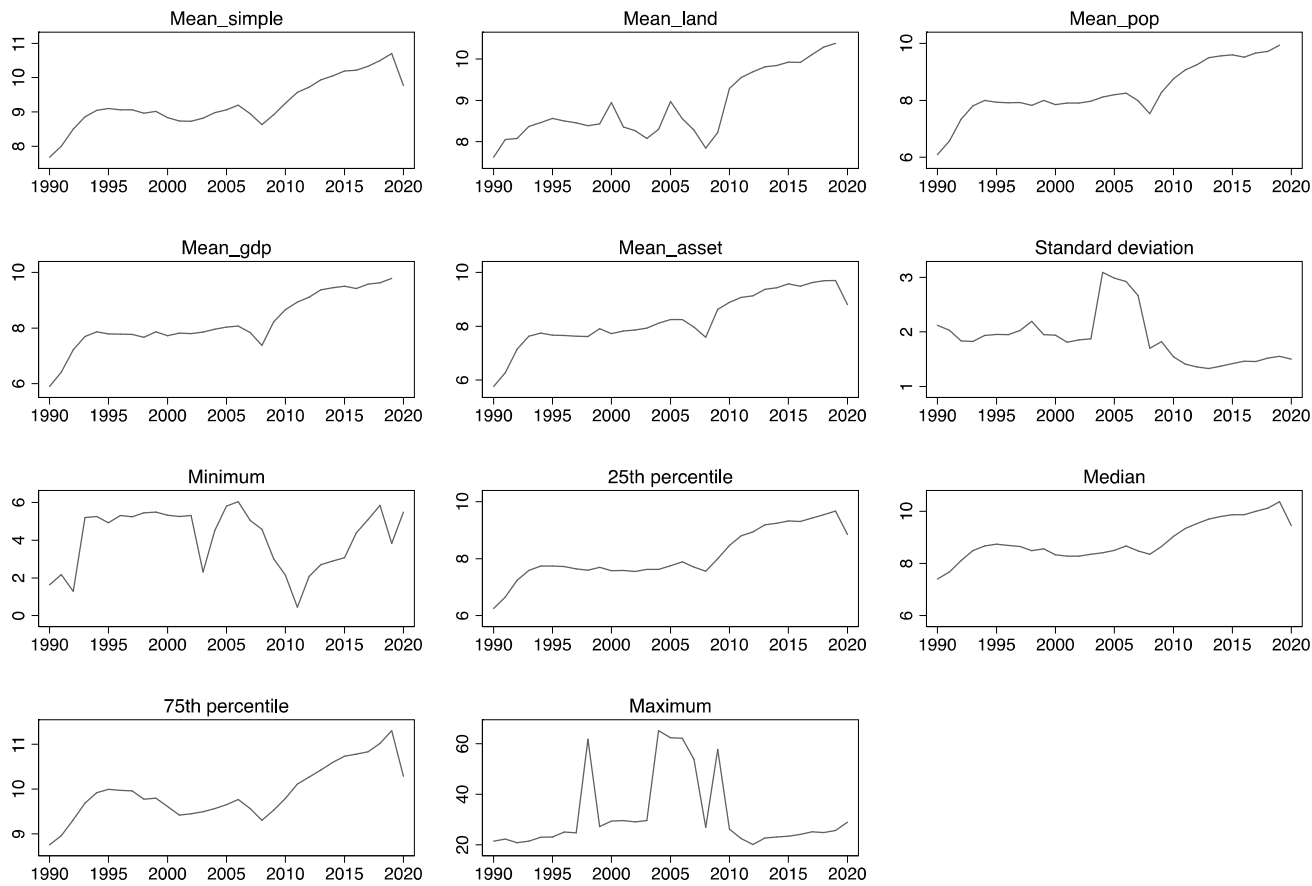
Figure III.3 Efficiency Ratio (\%)
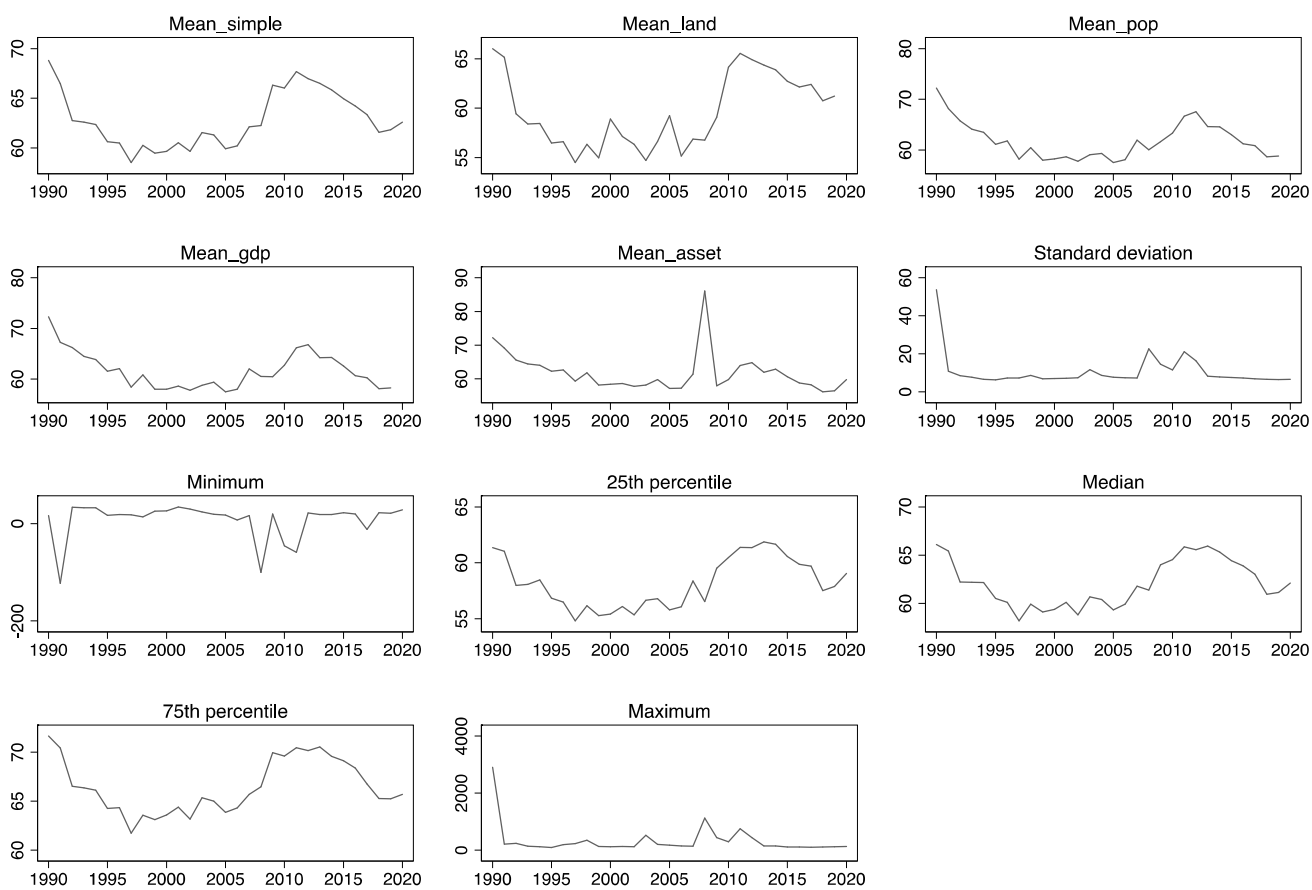

Figure III.4 Pretax Return on Assets (\%)
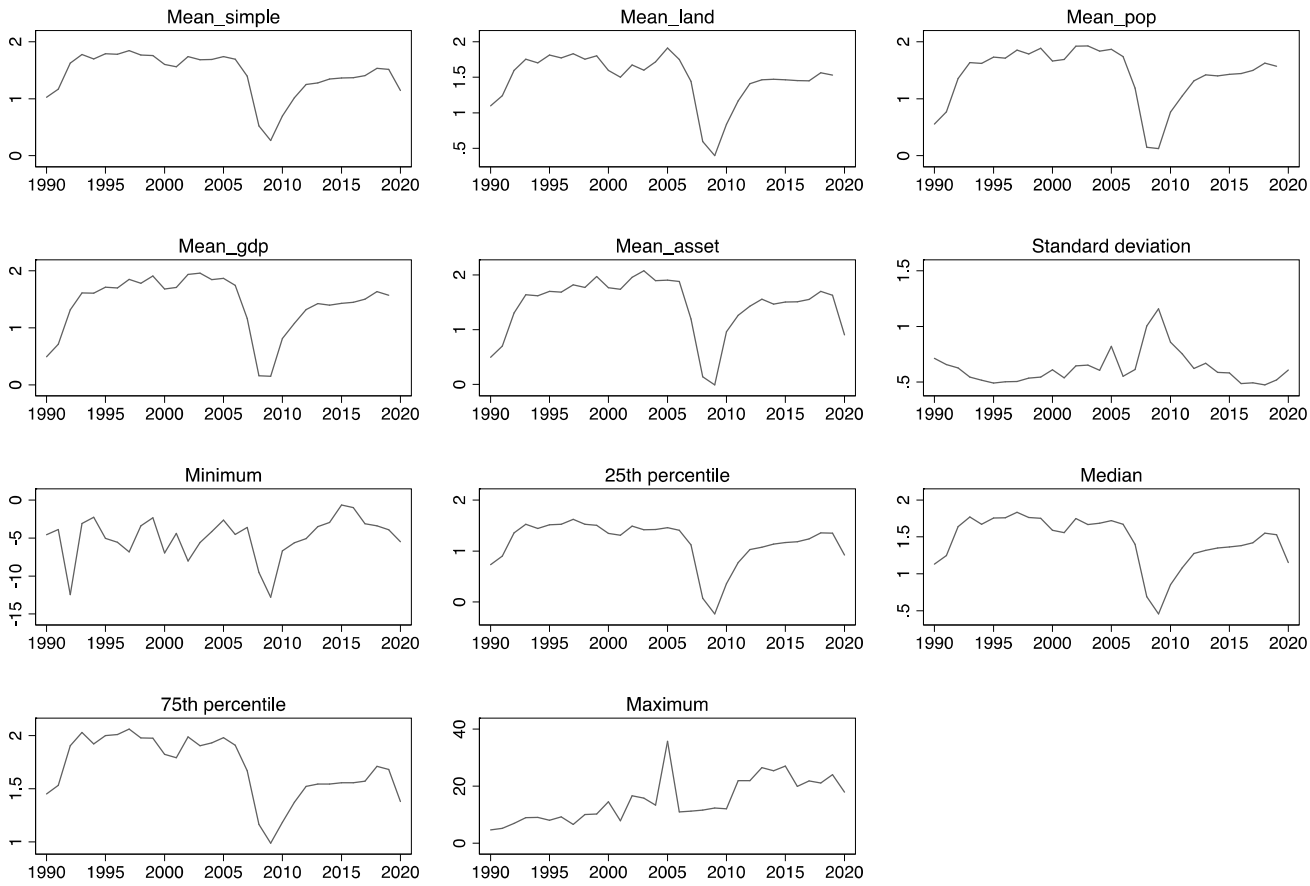
Figure III.5 Net Interest Margin (\%)
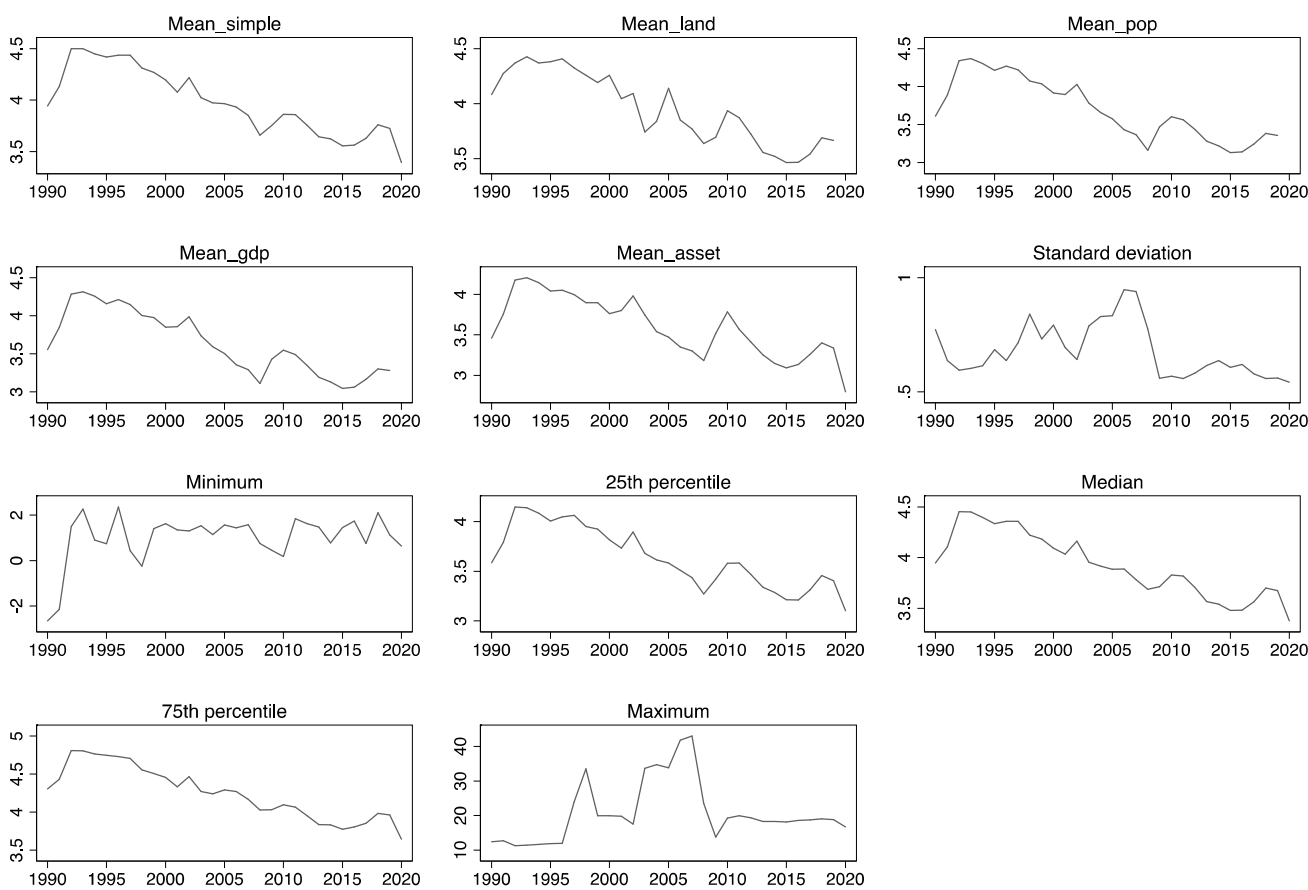

Figure III.6 Non-performing assets ratio (\%)
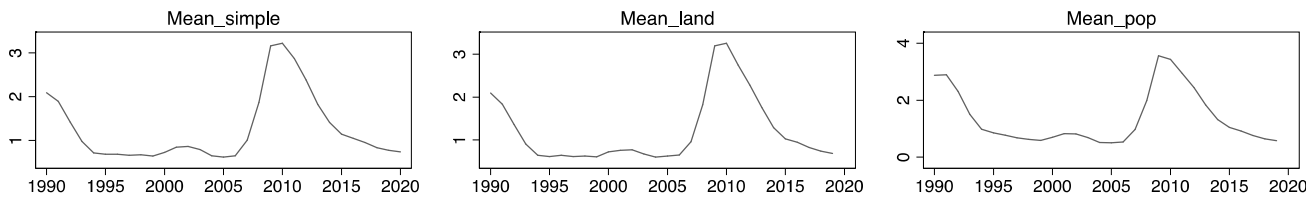

Mean_gdp
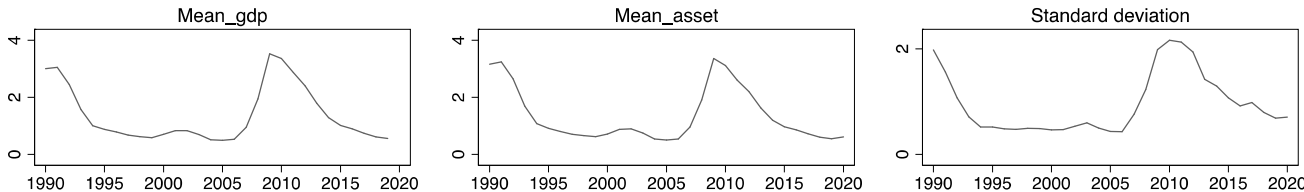

Minimum

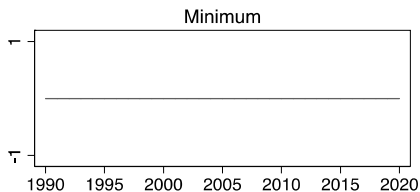

25th percentile
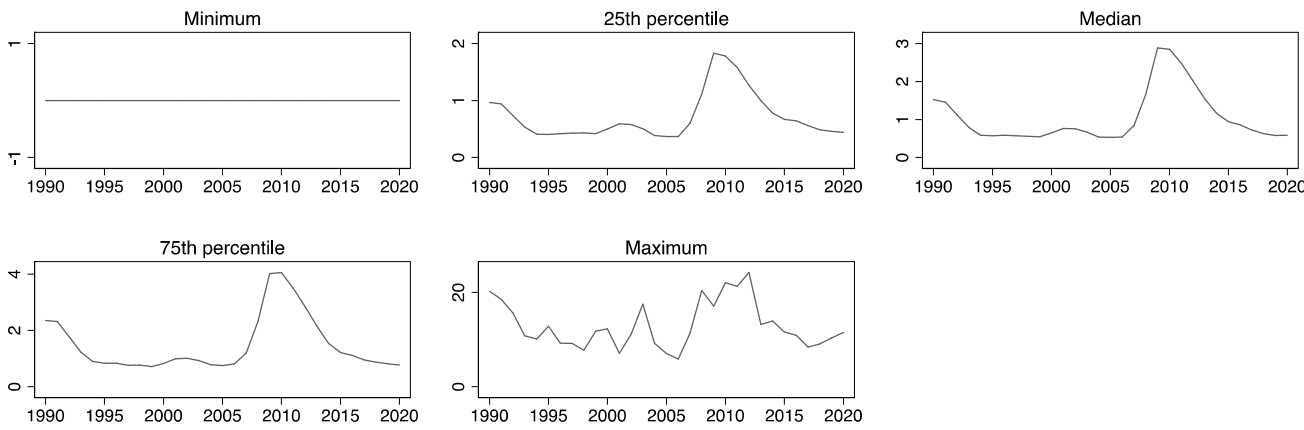
Annex 3 - Distribution across counties for the years 1990, 2000, 2010, 2019 

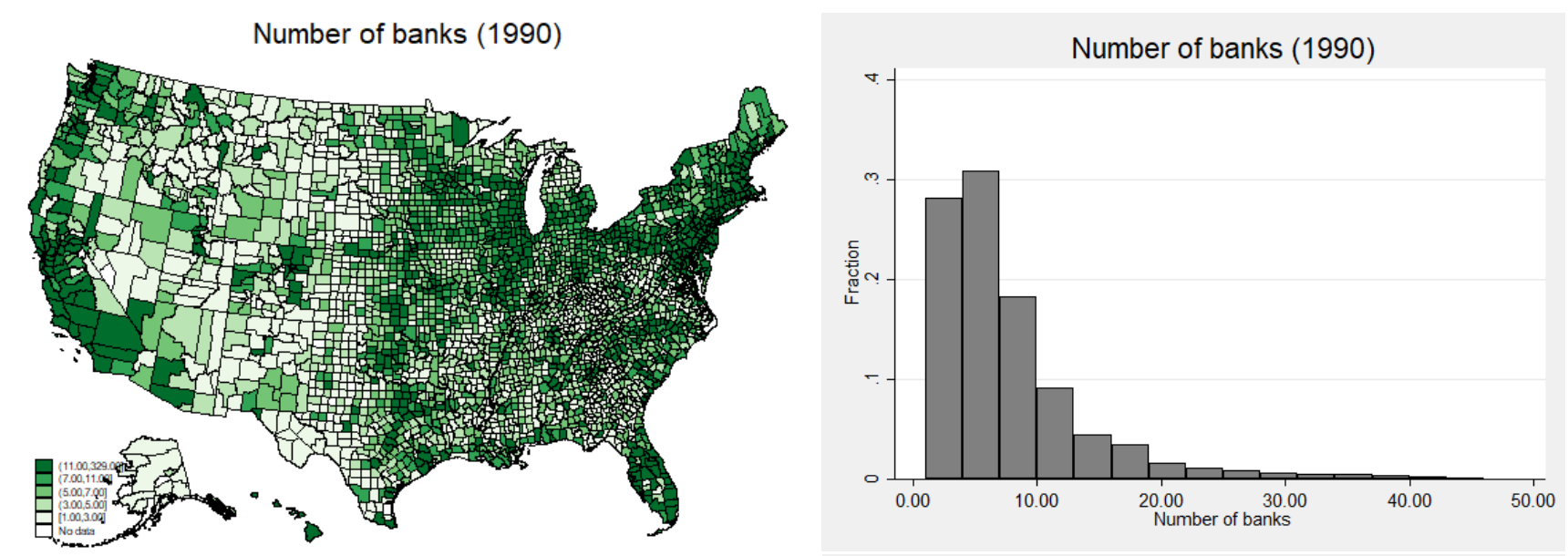

Number of banks (2000)

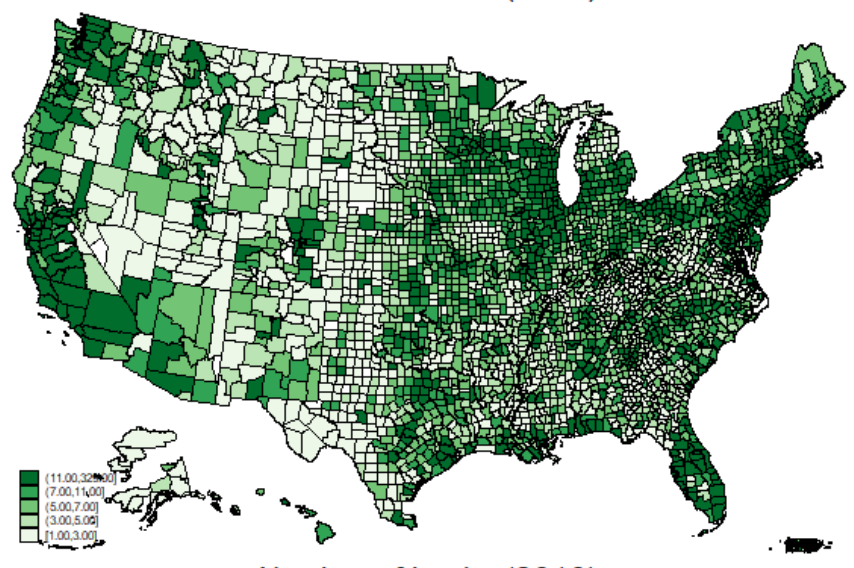

Number of banks (2000)

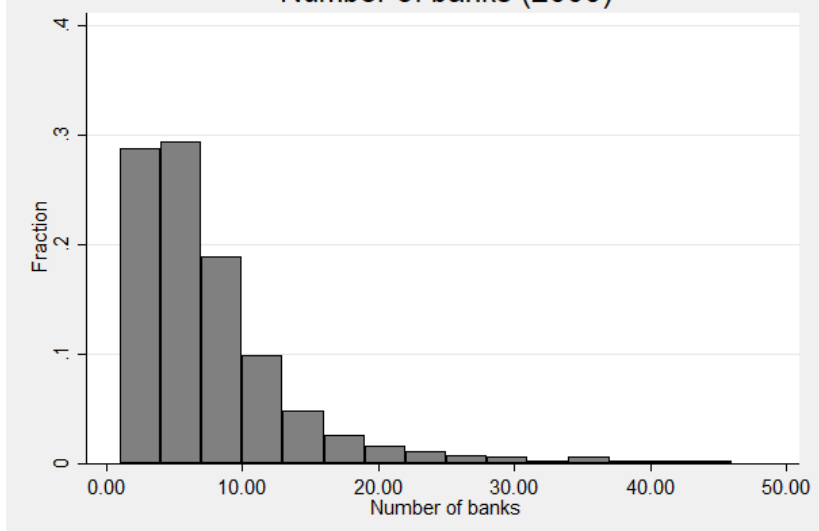

Number of banks (2010)

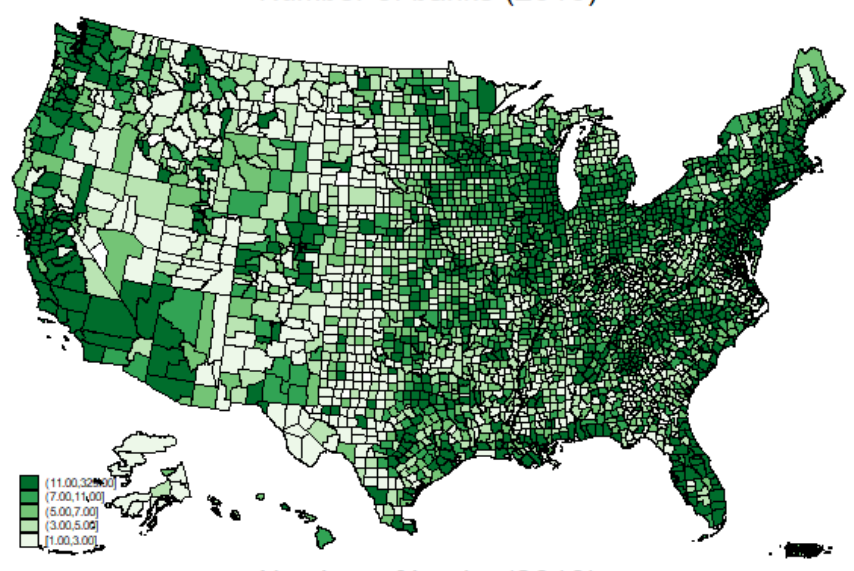

Number of banks (2010)

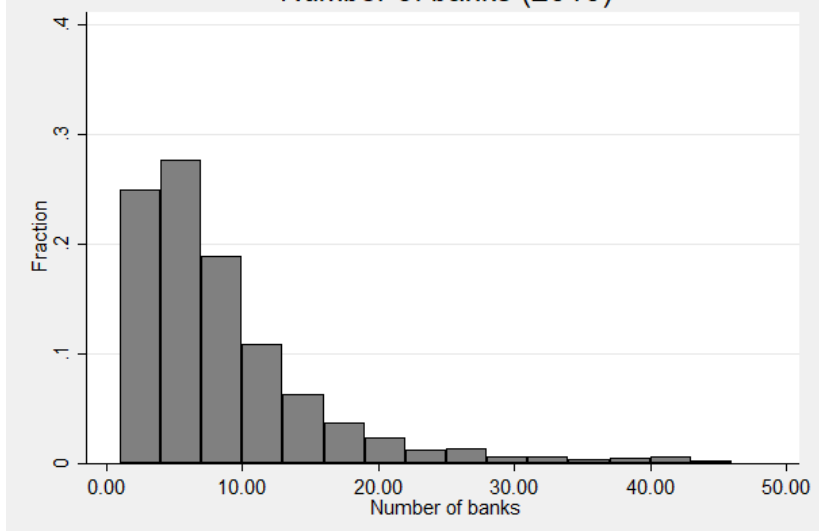

Number of banks (2019)

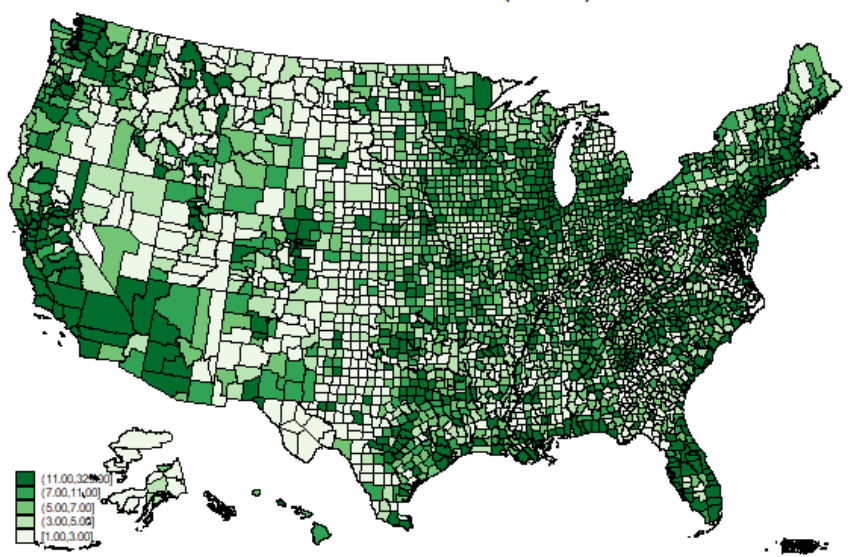

Number of banks (2019)

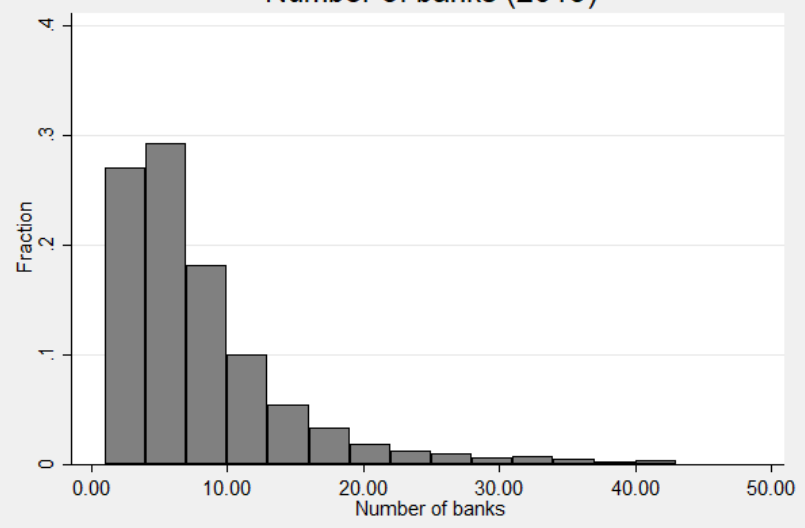

Note: This figure illustrates the number of banks in different counties and its distribution in 1990, 2000, 2010 and 2019. Brackets for the maps are based on quintiles in the year 2005. A darker area represents a larger number of banks in one particular county. The histogram represents the fraction of counties that fall into the range of one bar (width is equal to 3 , starting at value 1$)$. Outliers $(<1 \%$-percentile or $>99 \%$-percentile using all data points) are excluded for the histograms. Please see the Online Appendix for a dynamic representation of the maps and histograms for all years. 
Figure C2: Number of counties a bank operates in
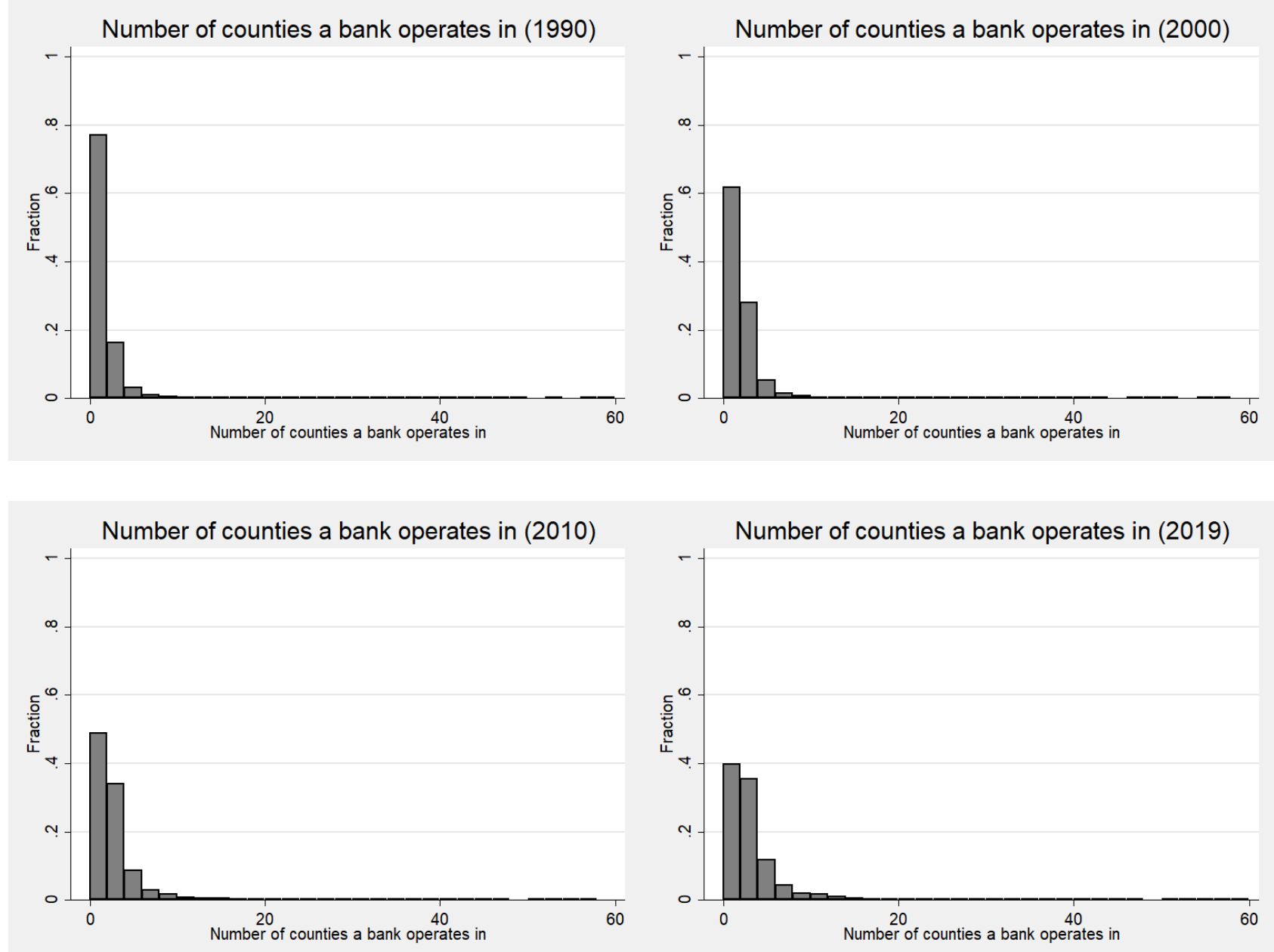

Note: This figure illustrates the distribution of the number of counties one specific banks operates in for the years 1990, 2000,2010 and 2019. The histogram represents the fraction of banks that fall into the range of one bar (width is equal to 2 , starting at value 0 , implying that the first bar represents the fraction of banks that operate in 1 county, the second bar represent the fraction of banks that operate in 2 or 3 counties etc.). Outliers (<1\%-percentile or $>99 \%$-percentile using all data points) are excluded for the histograms. Please see the Online Appendix for a dynamic representation of the maps and histograms for all years. 
Share of the largest bank by assets (\%) (1990)

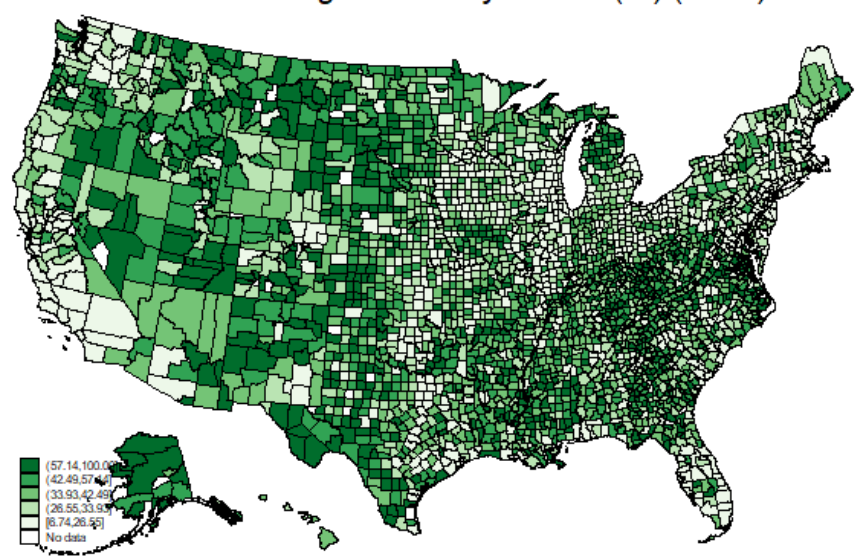

Share of the largest bank by assets (\%) (2000)
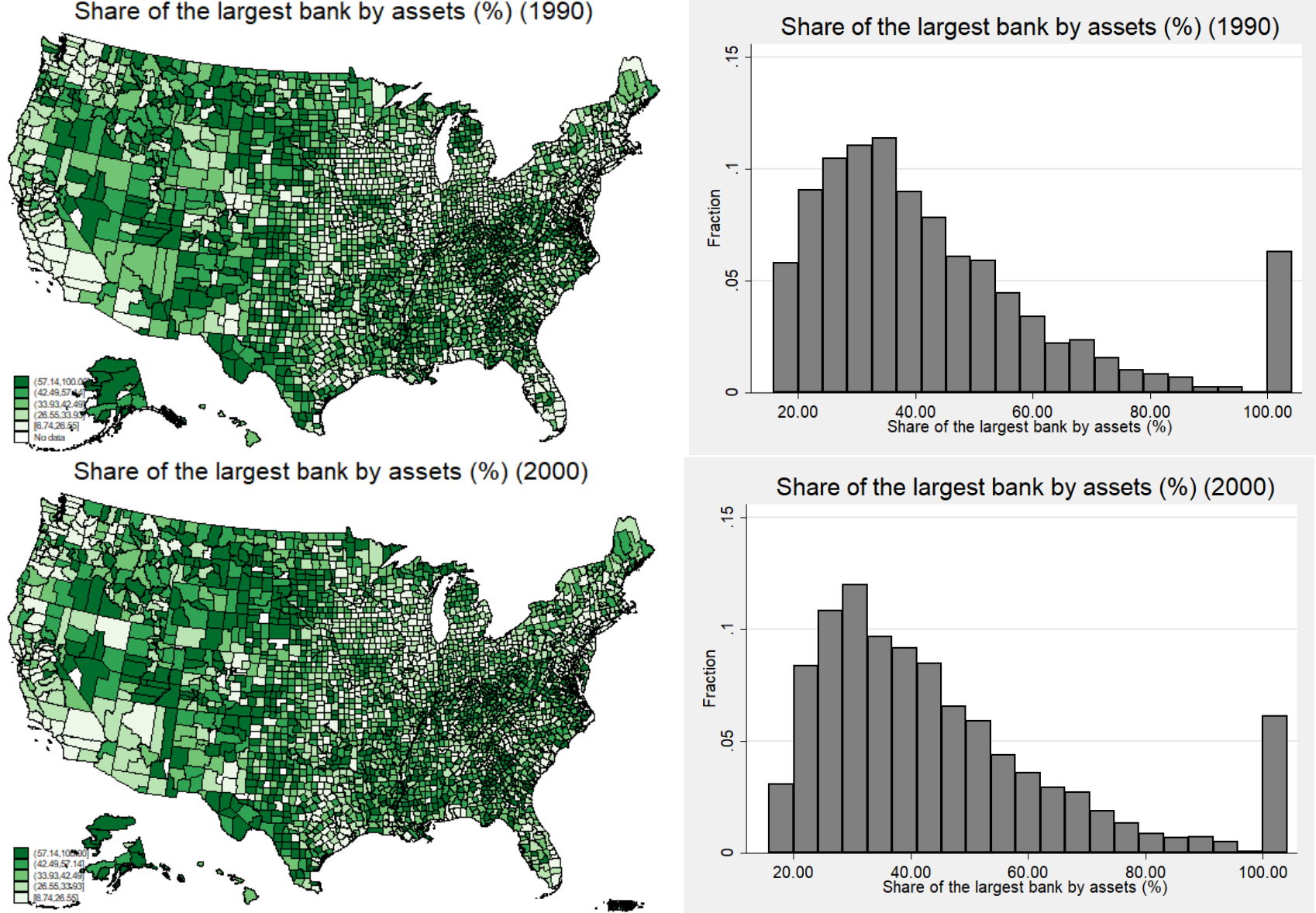

Share of the largest bank by assets (\%) (2010)

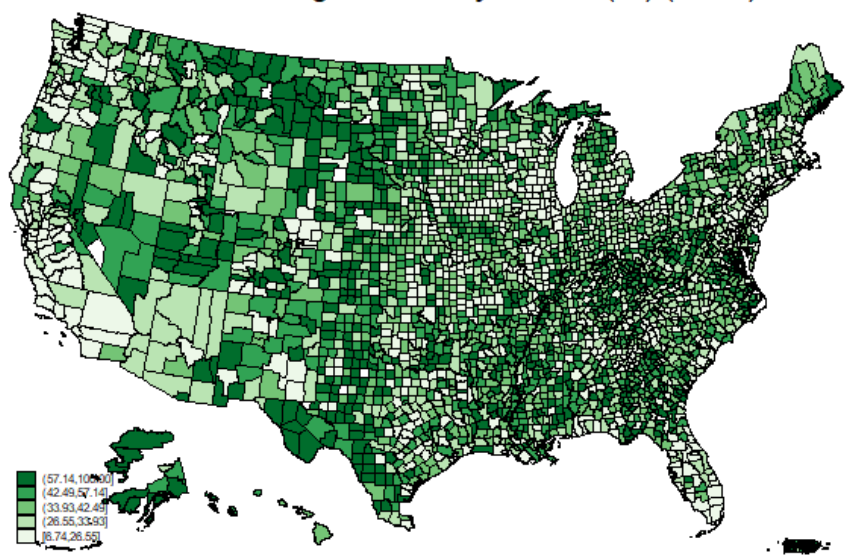

Share of the largest bank by assets (\%) (2019)

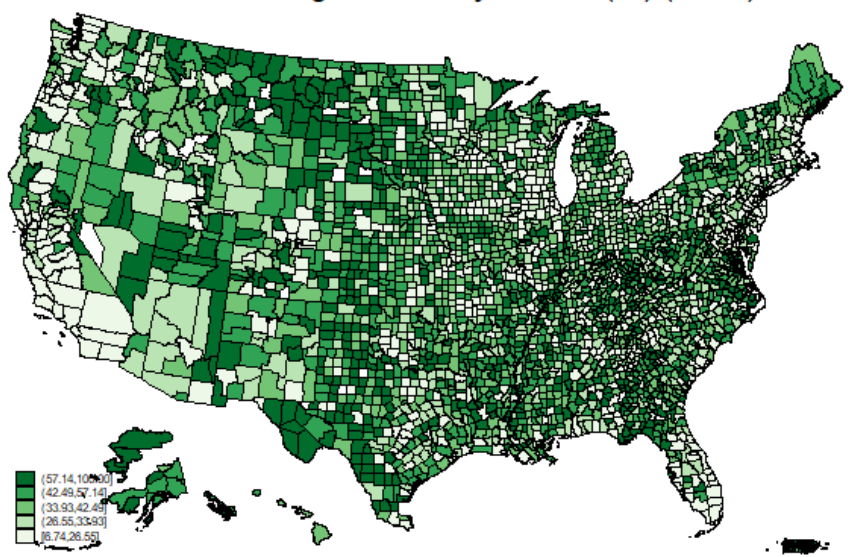

Share of the largest bank by assets (\%) (2000)

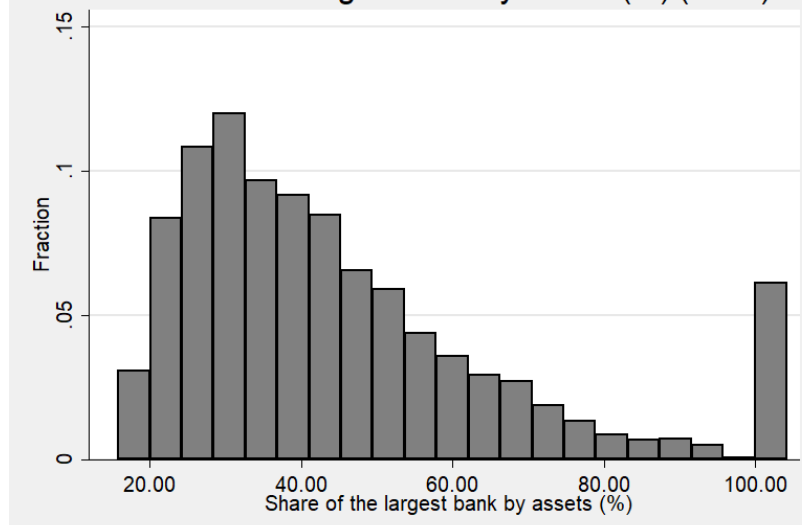

Share of the largest bank by assets (\%) (2010)

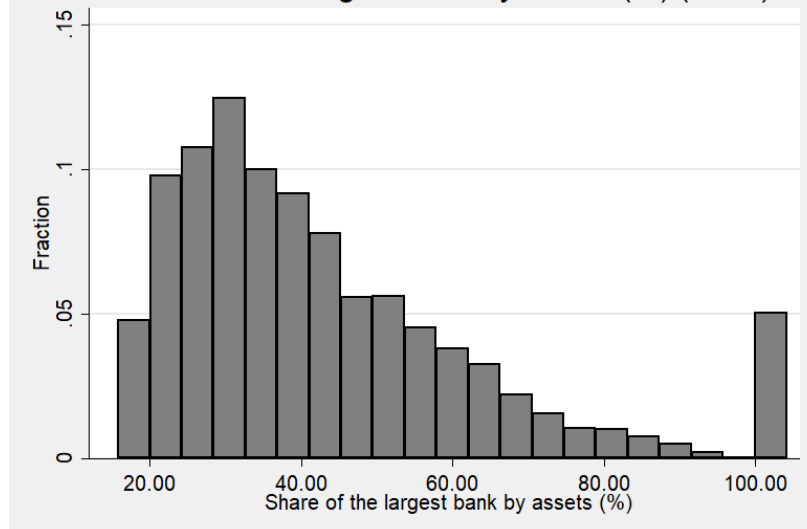

Share of the largest bank by assets (\%) (2019)

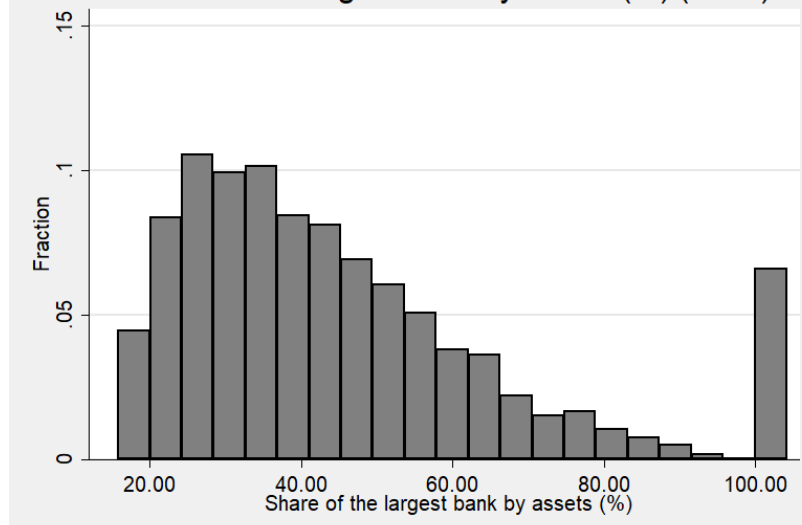

Note: This figure illustrates the share of the largest bank by assets in each county and its distribution in 1990, 2000, 2010 and 2019. Brackets for the maps are based on quintiles in the year 2005. A darker area represents a larger share of the largest bank by assets in one particular county. The histogram represents the fraction of counties that fall into the range of one bar (width is equal to $4.21 \%$, starting at value $15.86 \%$ ). Outliers (<1\%-percentile or $>99 \%$-percentile using all data points) are excluded for the histograms. Please see the Online Appendix for a dynamic representation of the maps and histograms for all years. 
Figure C4: Share of community banks by assets (\%)

Share of community banks by assets (\%) (1990)

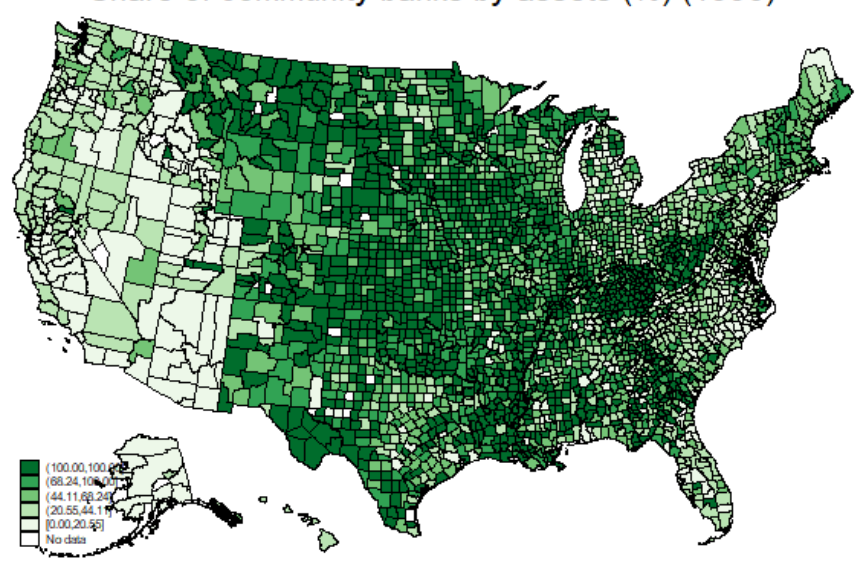

Share of community banks by assets (\%) (2000)
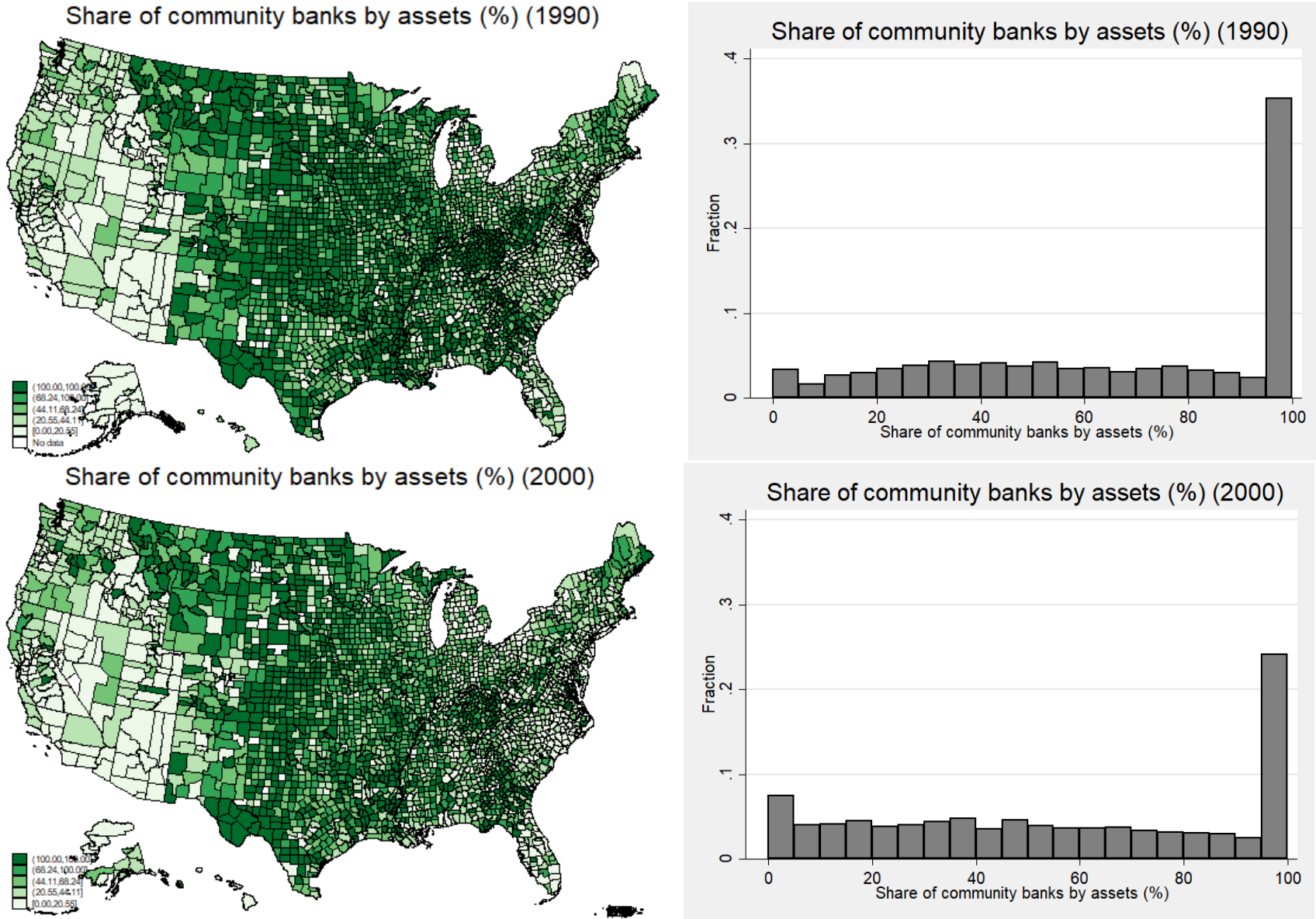

Share of community banks by assets (\%) (2010)

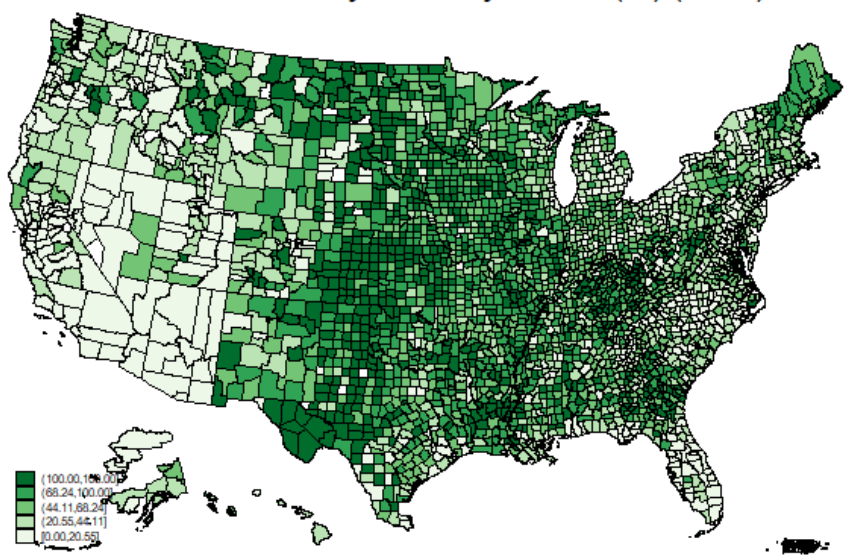

Share of community banks by assets (\%) (2019)

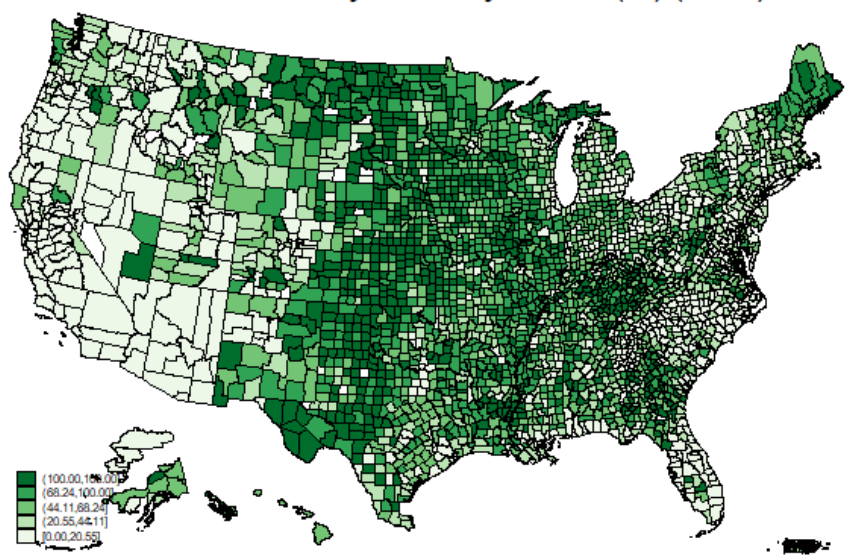

Share of community banks by assets (\%) (2000)

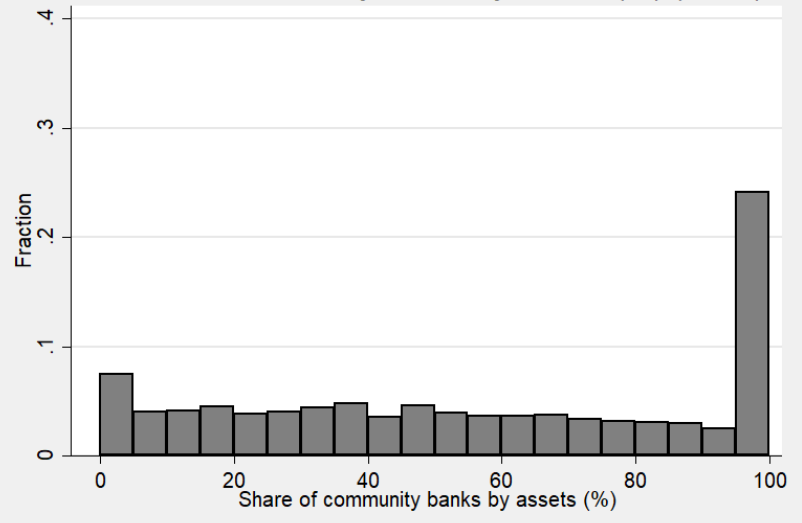

Share of community banks by assets (\%) (2010)

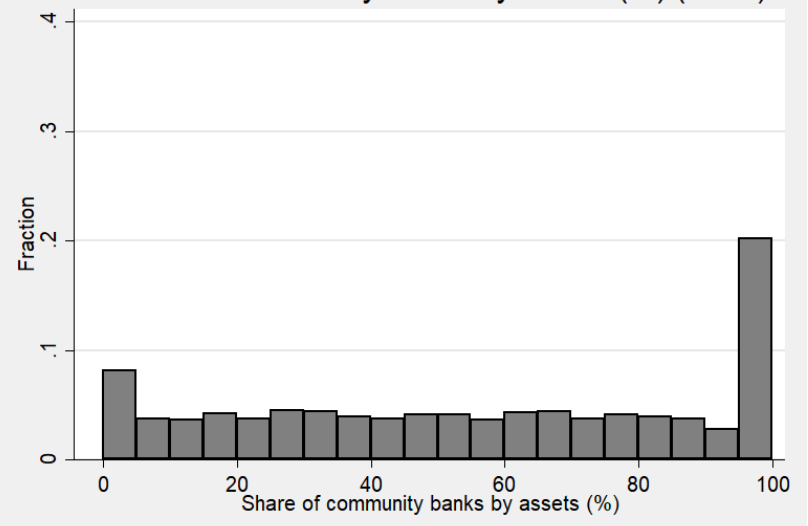

Share of community banks by assets (\%) (2019)

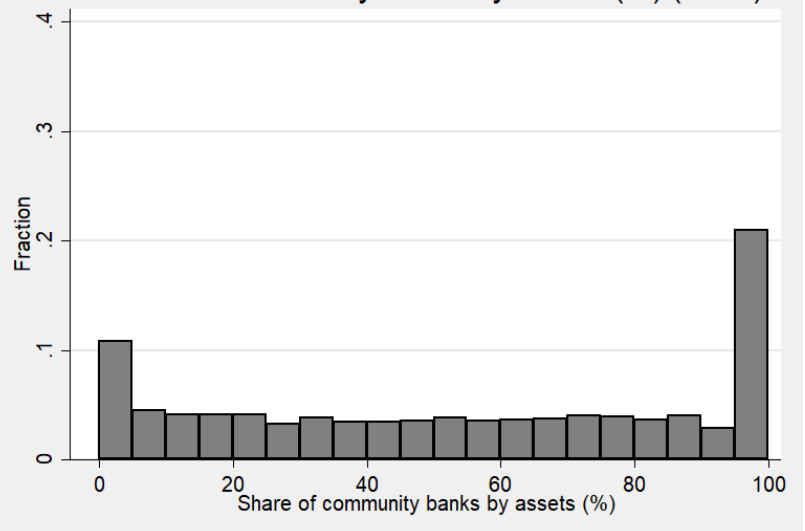

Note: This figure illustrates the share of community banks by assets in each county and its distribution in 1990, 2000, 2010 and 2019. Brackets for the maps are based on quintiles in the year 2005. A darker area represents a larger share of community banks by assets in one particular county. The histogram represents the fraction of counties that fall into the range of one bar (width is equal to $5 \%$, starting at value $0 \%$ ). Please see the Online Appendix for a dynamic representation of the maps and histograms for all years. 
Figure C5: Share of top 5 US banks by assets (\%)

Share of top 5 US banks by assets (\%) (1990)

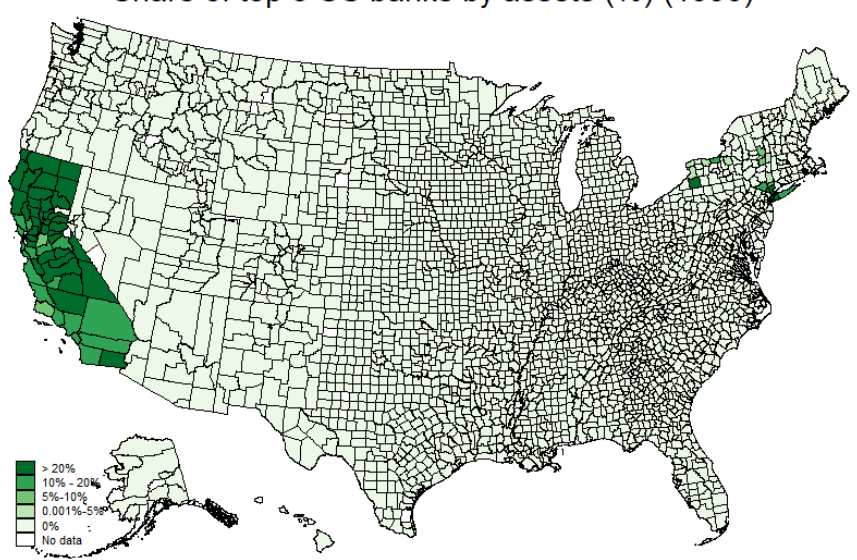

Share of top 5 US banks by assets (\%) (2000)

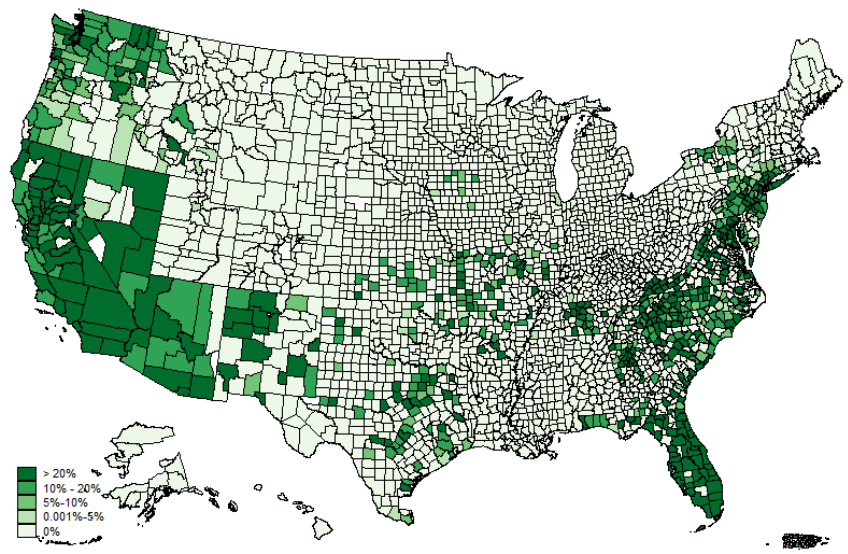

Share of top 5 US banks by assets (\%) (2010)

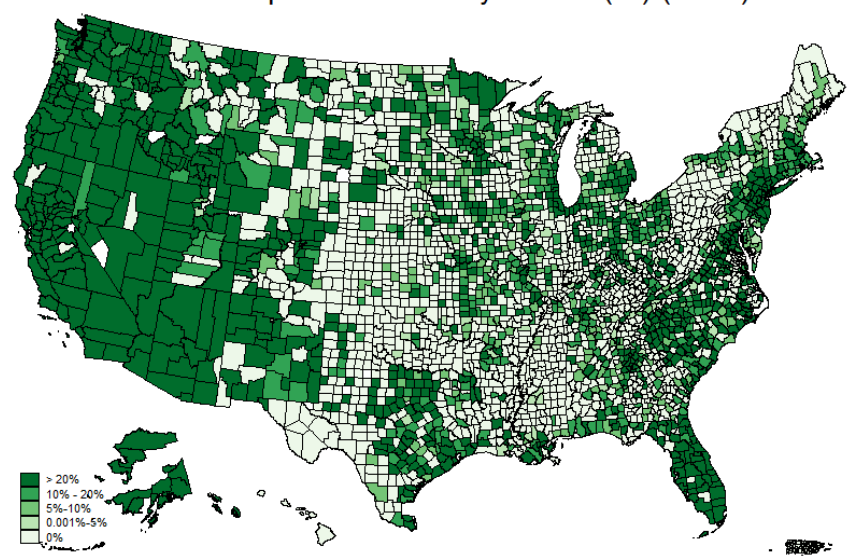

Share of top 5 US banks by assets (\%) (2019)

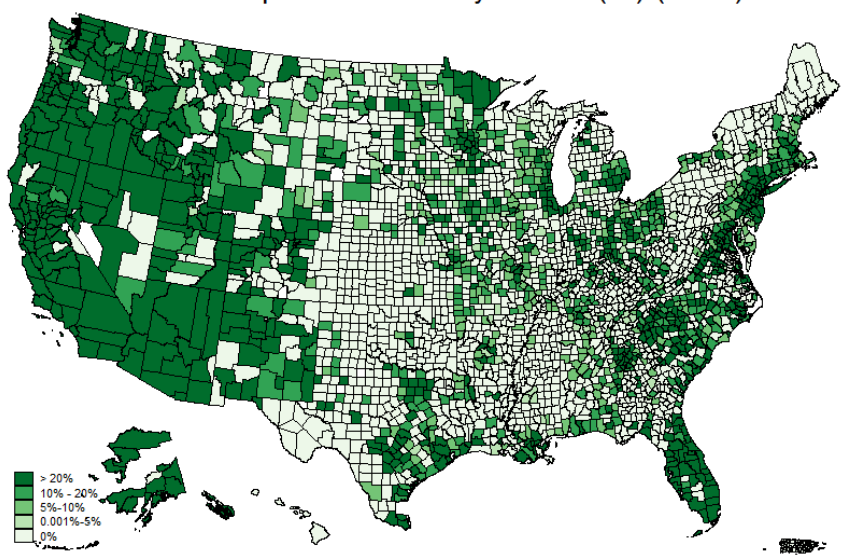

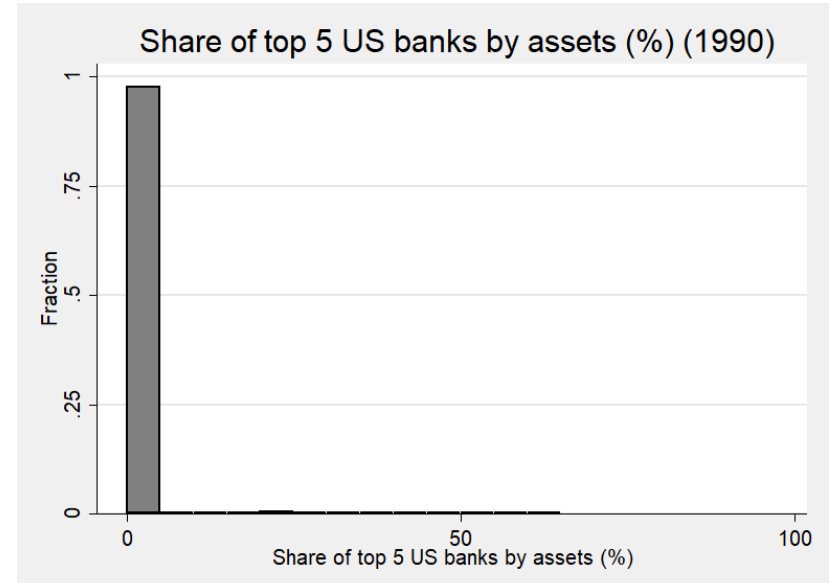

Share of top 5 US banks by assets (\%) (2000)

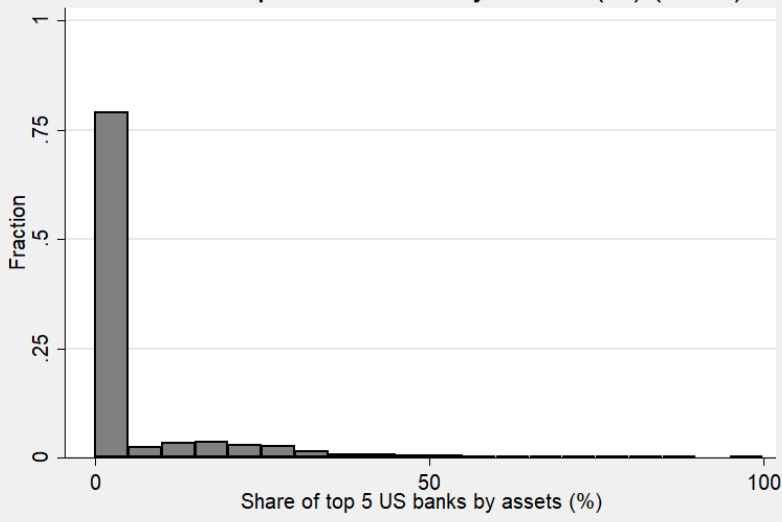

Share of top 5 US banks by assets (\%) (2010)

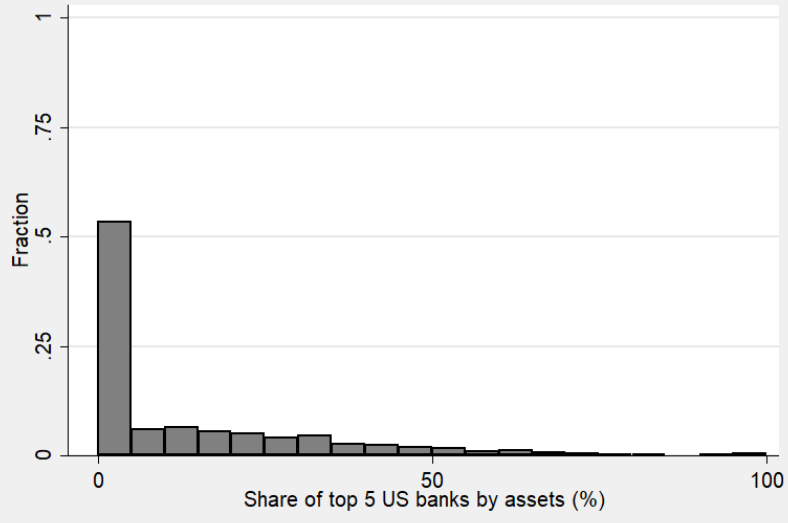

Share of top 5 US banks by assets (\%) (2019)

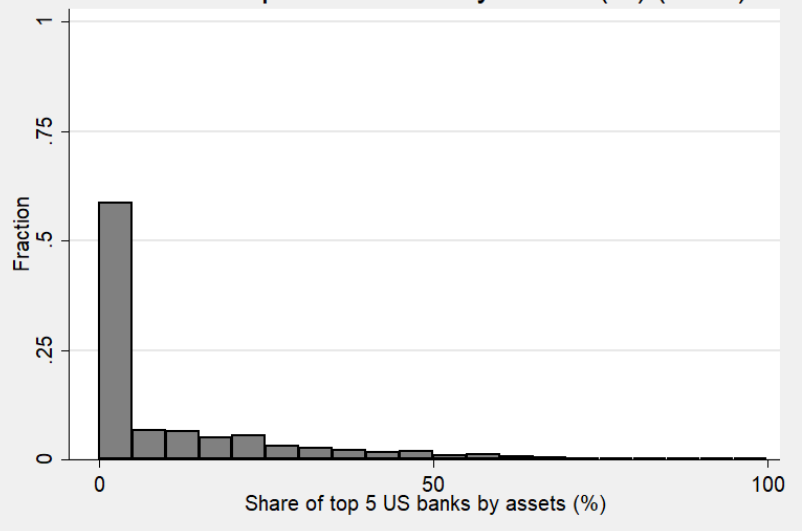

Note: This figure illustrates the share of the 5 largest US banks by assets in each county and its distribution in 1990, 2000, 2010 and 2019. A darker area represents a larger share in one particular county. The composition of this group changes over time, being defined by the 5 largest banks by assets each year. The histogram represents the fraction of counties that fall into the range of one bar (width is equal to $5 \%$, starting at value $0 \%$ ). Please see the Online Appendix for a dynamic representation of the maps and histograms for all years. 
Figure C6: Per capita deposits (\$ Thou.)

Per capita deposits (\$ Thou) (1990)
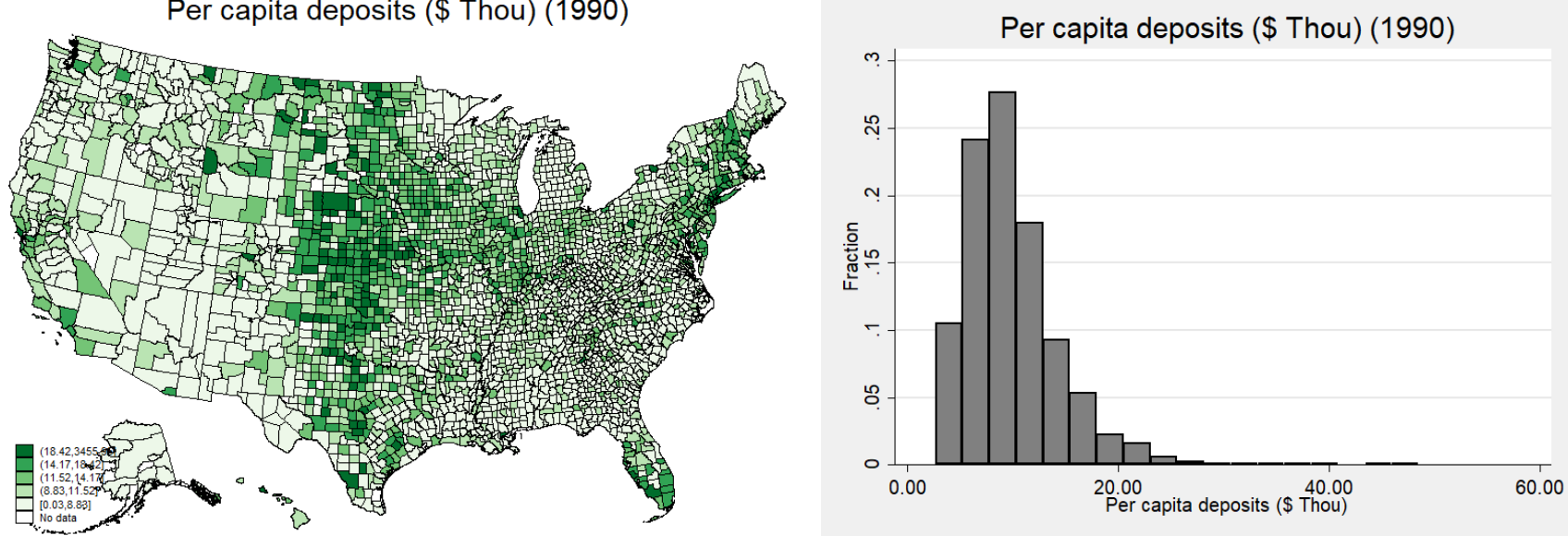

Per capita deposits (\$ Thou) (2000)

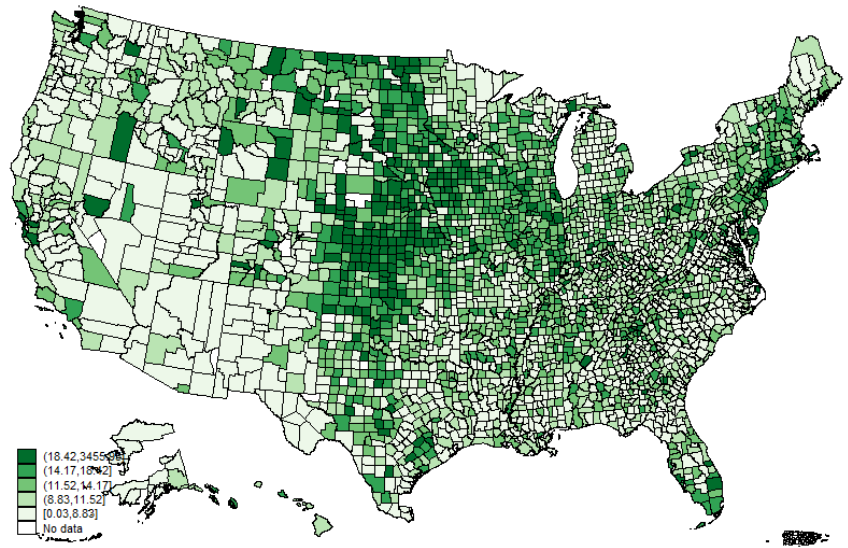

Per capita deposits (\$ Thou) (2000)

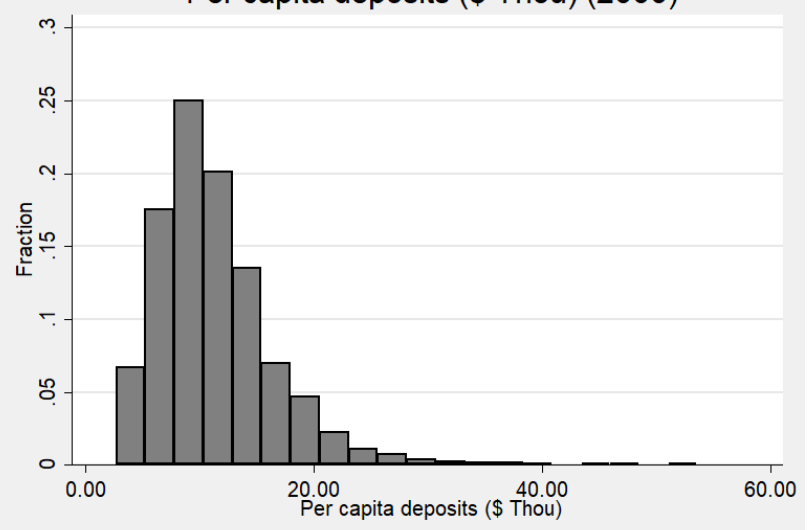

Per capita deposits (\$ Thou) (2010)

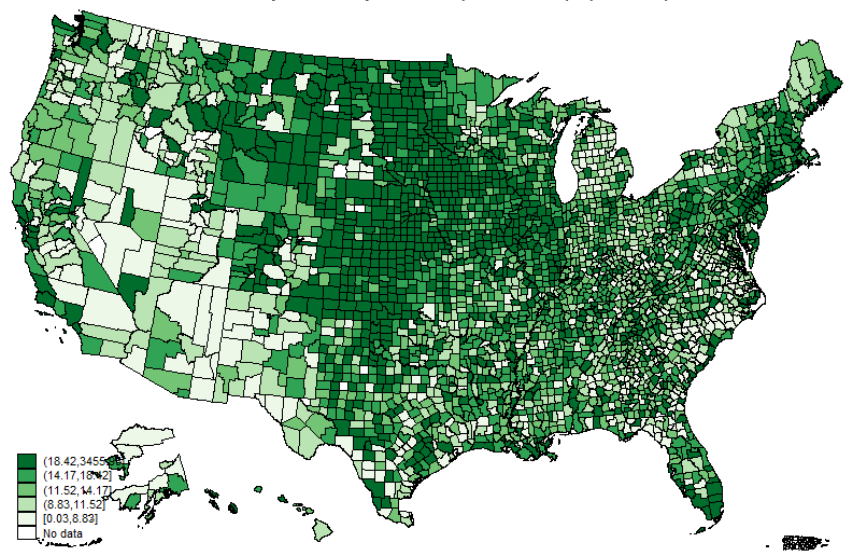

Per capita deposits (\$ Thou) (2010)

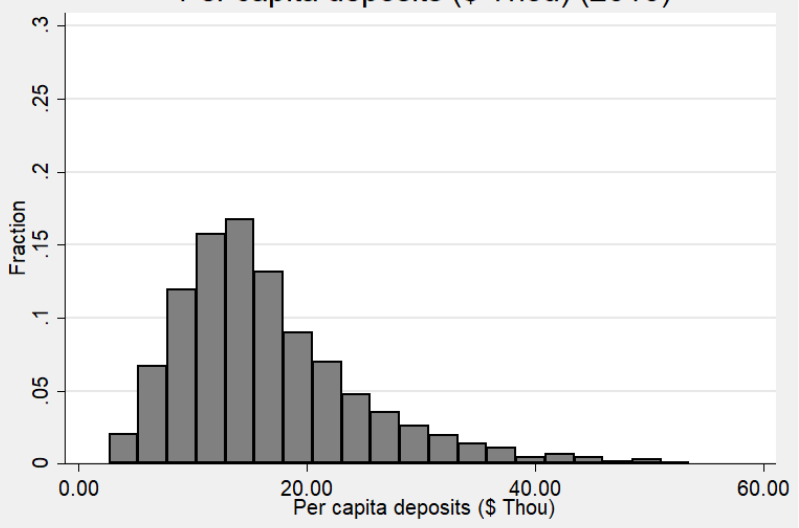

Per capita deposits (\$ Thou) (2019)

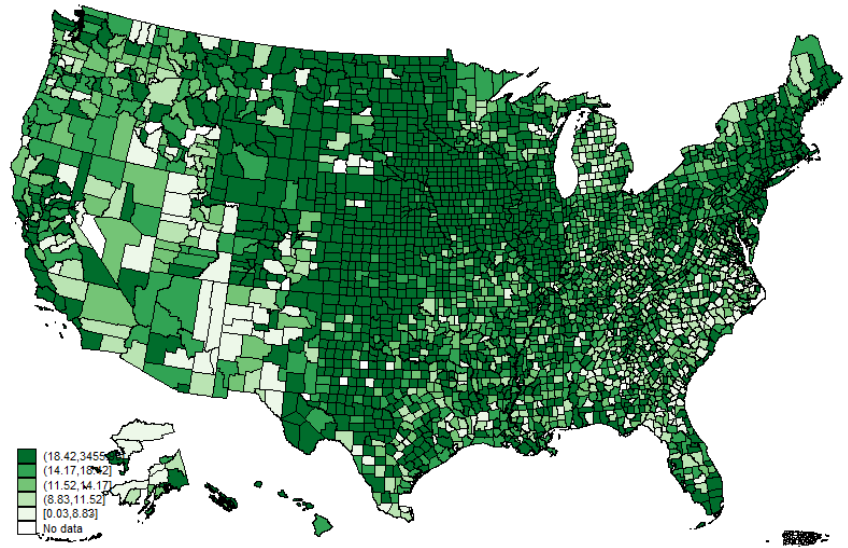

Per capita deposits (\$ Thou) (2019)

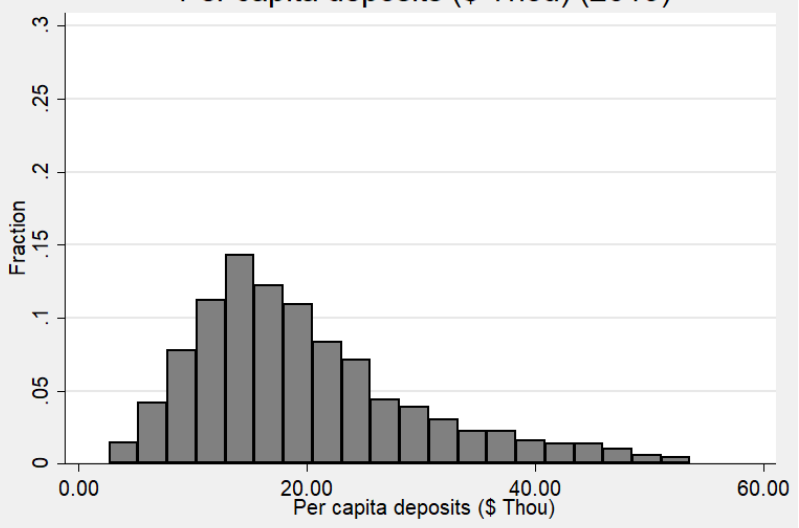

Note: This figure illustrates the average per capita deposits (in \$ Thousands) in each county and its distribution in 1990, 2000,2010 and 2019. Brackets for the maps are based on quintiles in the year 2005. A darker area represents larger average per capita deposits in one particular county. The histogram represents the fraction of counties that fall into the range of one bar (width is equal to $\$ 2.54$ Thou., starting at value $\$ 2.74$ Thou.). Outliers (<1\%-percentile or $>99 \%$-percentile using all data points) are excluded for the histograms. Please see the Online Appendix for a dynamic representation of the maps and histograms for all years. 

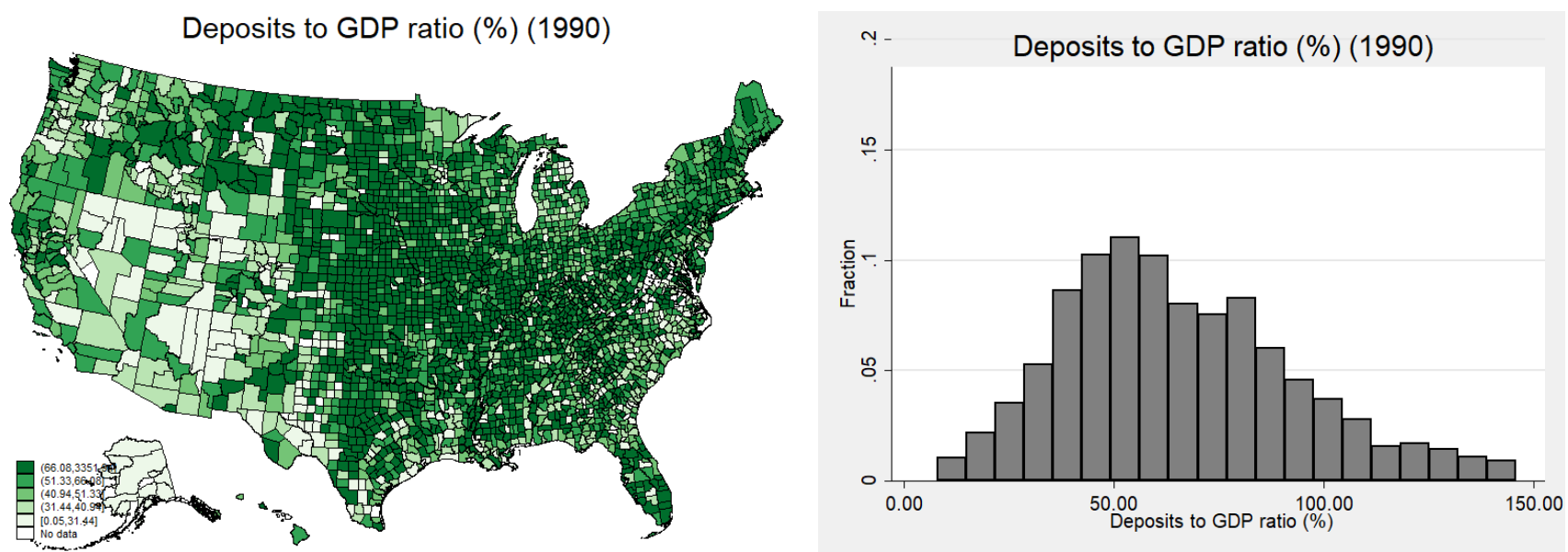

Deposits to GDP ratio (\%) (2000)

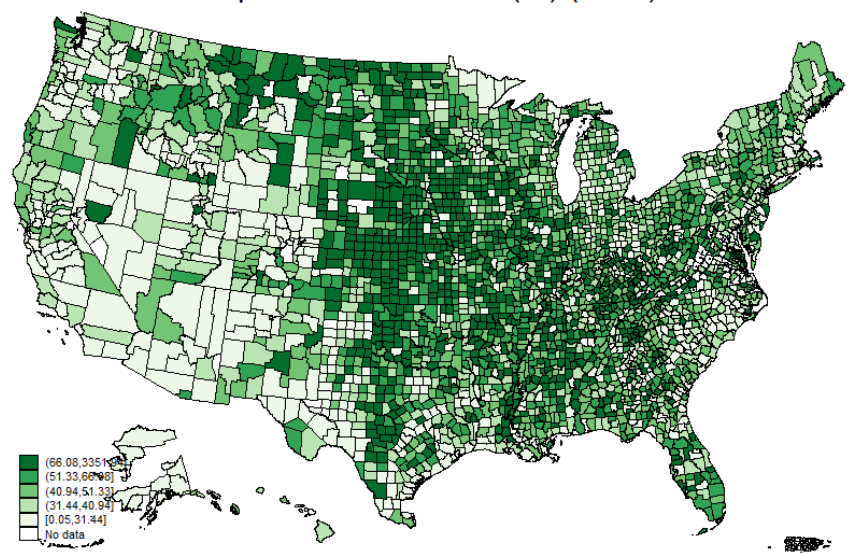

N - Deposits to GDP ratio (\%) (2000)

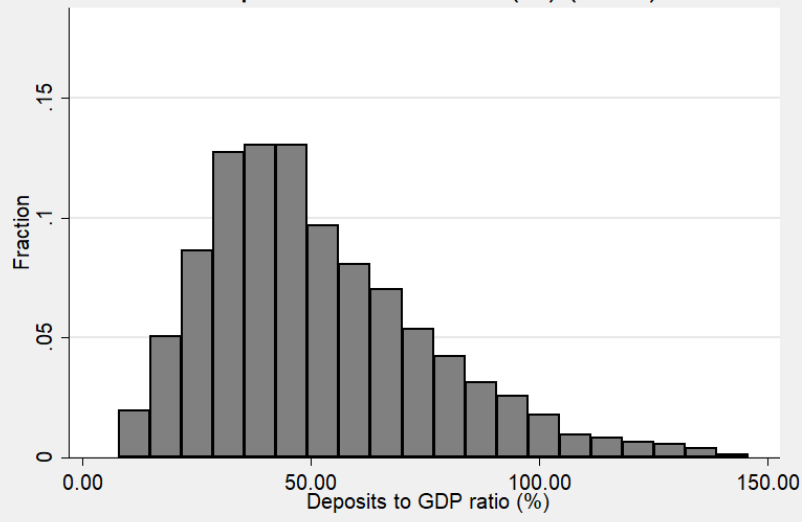

Deposits to GDP ratio (\%) (2010)

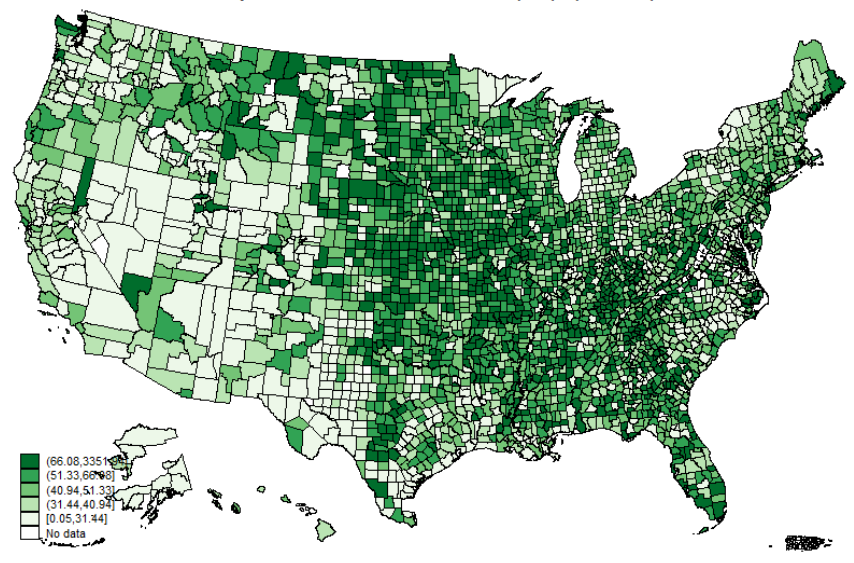

\% - Deposits to GDP ratio (\%) (2010)

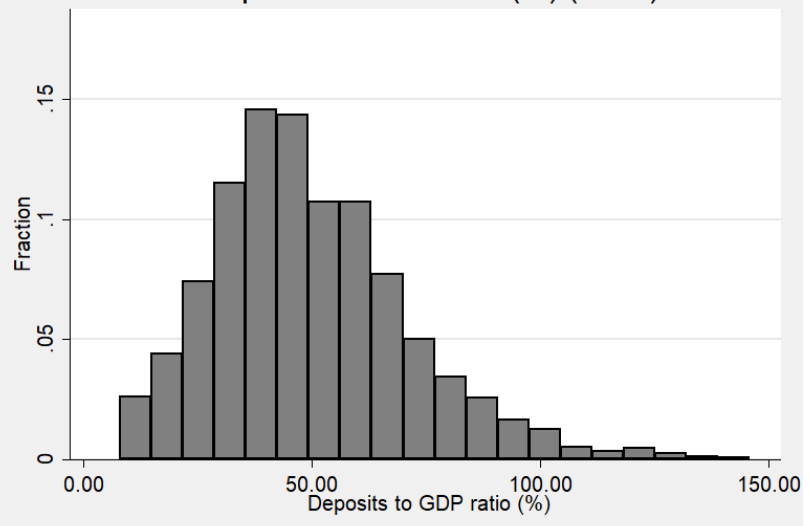

Deposits to GDP ratio (\%) (2019)

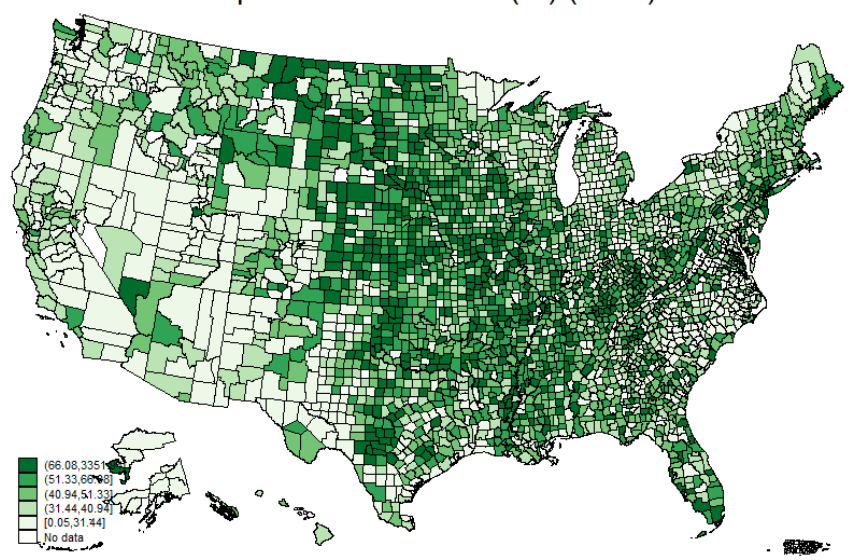

ฯ - $\quad$ Deposits to GDP ratio (\%) (2019)

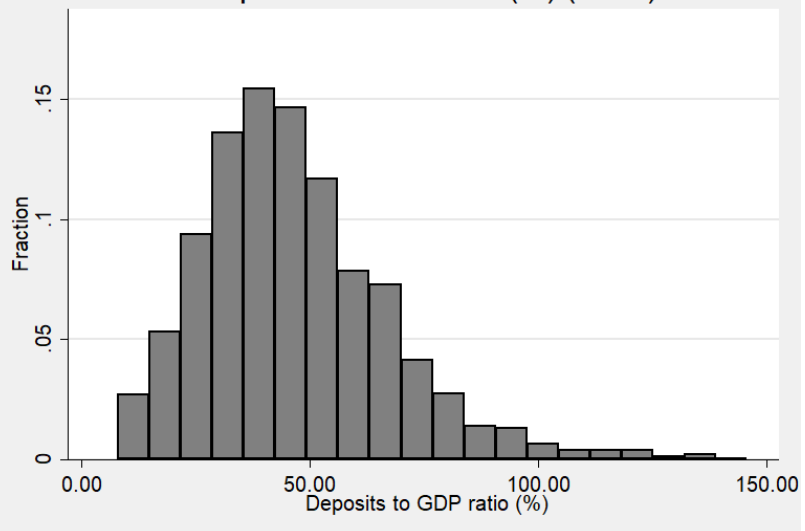

Note: This figure illustrates the average bank deposits to GDP ratios in each county and its distribution in 1990, 2000, 2010 and 2019. Brackets for the maps are based on quintiles in the year 2005. A darker area represents larger ratio in one particular county. The histogram represents the fraction of counties that fall into the range of one bar (width is equal to $8.08 \%$., starting at value $6.89 \%$ ). Outliers (<1\%-percentile or $>99 \%$ percentile using all data points) are excluded for the histograms. Please see the Online Appendix for a dynamic representation of the maps and histograms for all years. 
Figure C8: Per capita assets (\$ Thou.)

Per capita assets (\$ Thou) (1990)
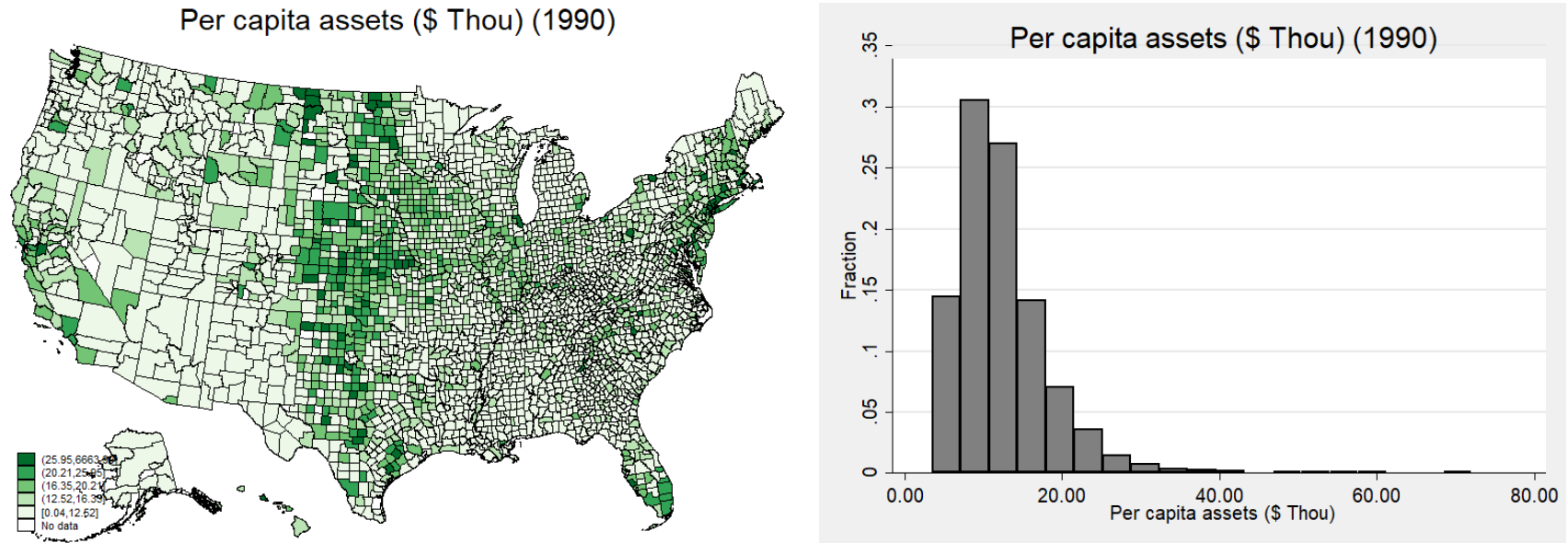

Per capita assets (\$ Thou) (2000)
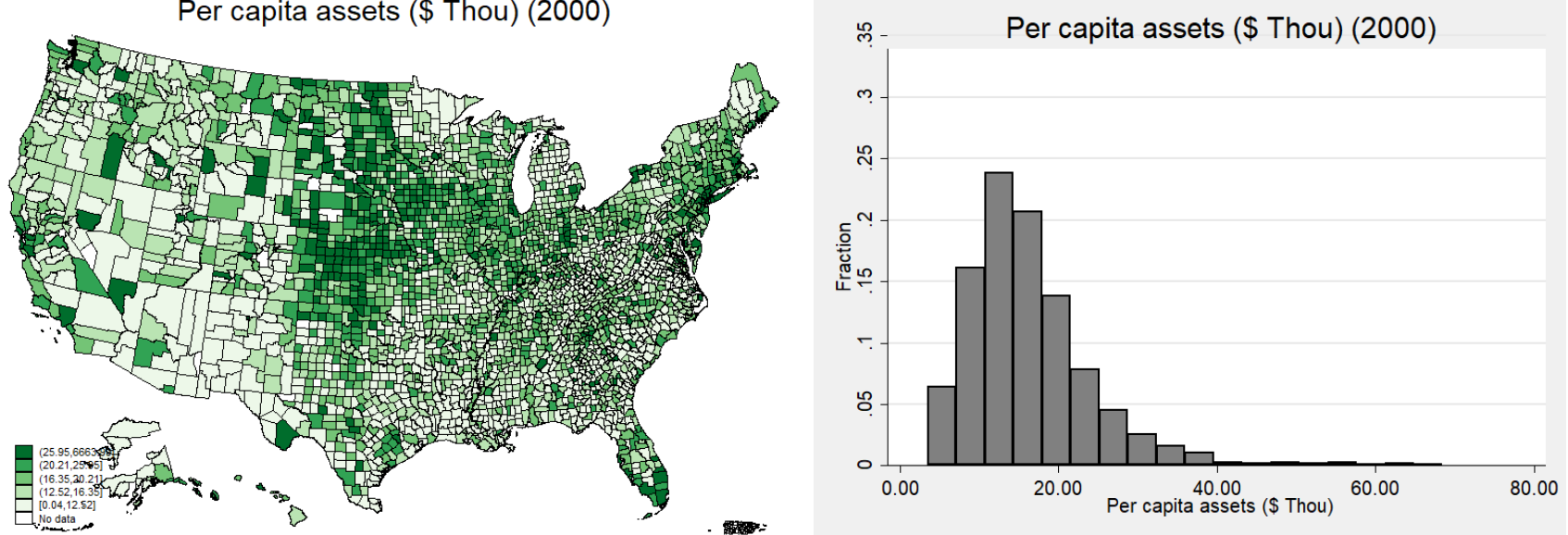

Per capita assets (\$ Thou) (2010)

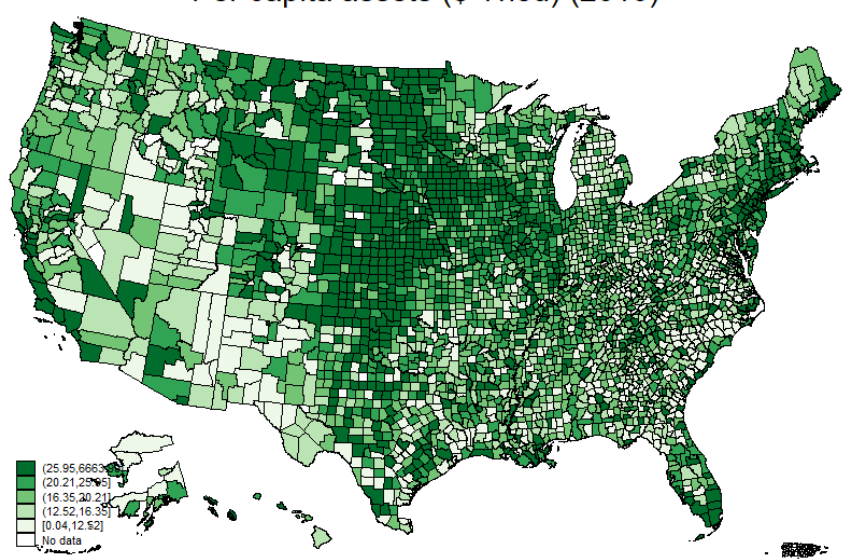

Per capita assets (\$ Thou) (2019)

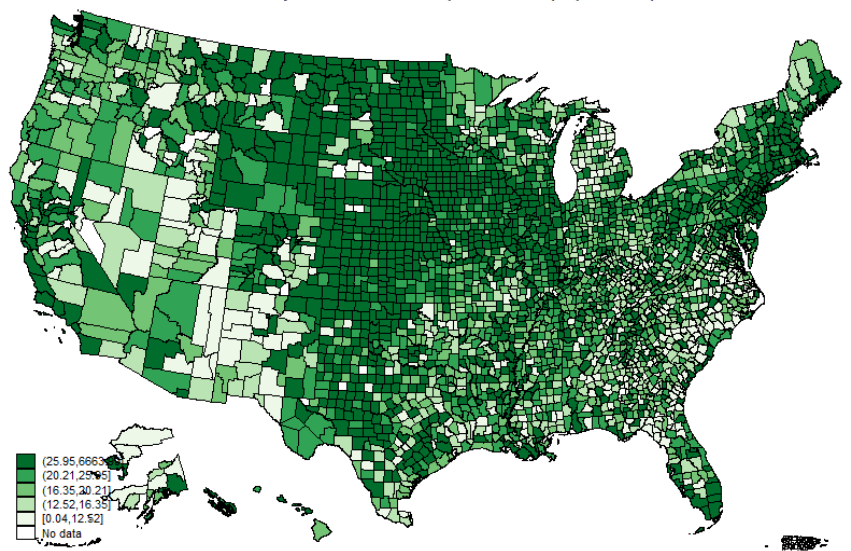

@ Per capita assets (\$ Thou) (2010)

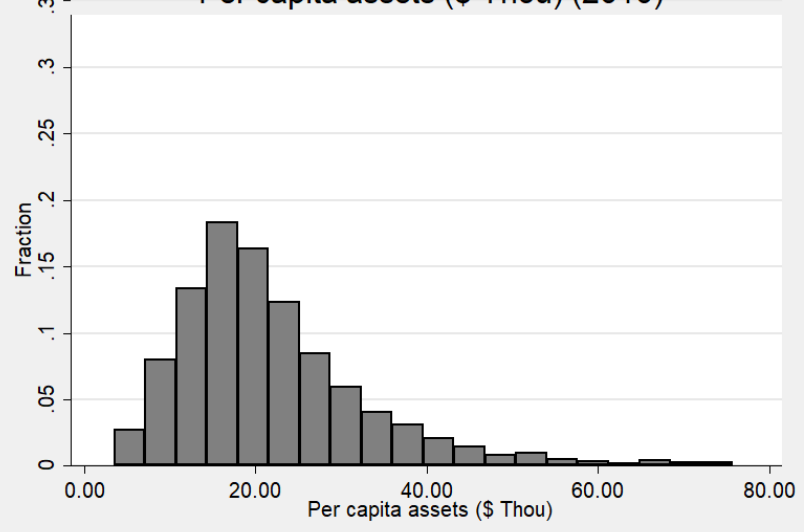

@ $\quad$ Per capita assets (\$ Thou) (2019)

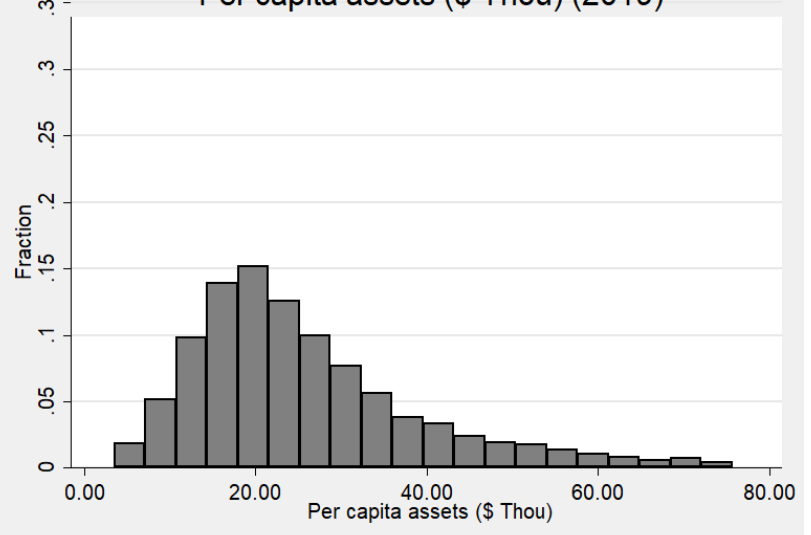

Note: This figure illustrates the average per capita assets (in \$ Thousands) in each county and its distribution in 1990, 2000, 2010 and 2019. Brackets for the maps are based on quintiles in the year 2005. A darker area represents larger average per capita assets in one particular county. The histogram represents the fraction of counties that fall into the range of one bar (width is equal to $\$ 3.61$ Thou., starting at value $\$ 3.54$ Thou.). Outliers ( $<1 \%$-percentile or $>99 \%$-percentile using all data points) are excluded for the histograms. Please see the Online Appendix for a dynamic representation of the maps and histograms for all years. 

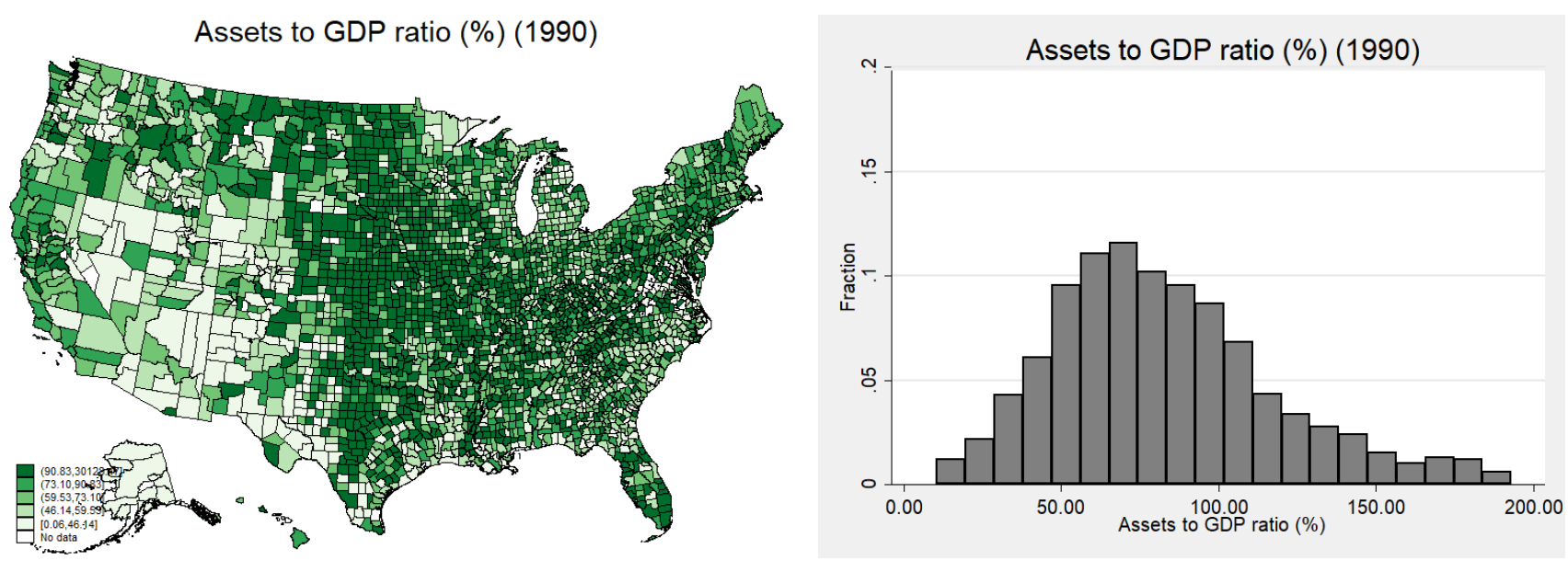

Assets to GDP ratio (\%) (2000)

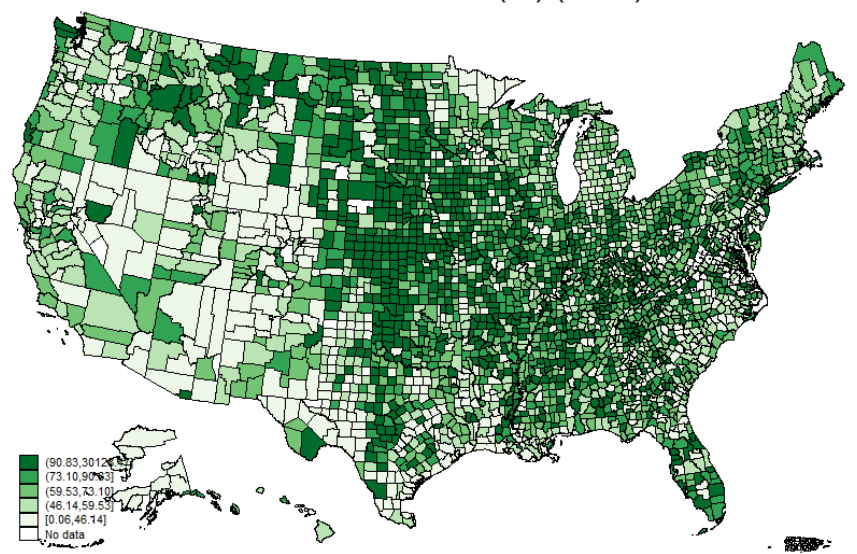

Assets to GDP ratio (\%) (2000)

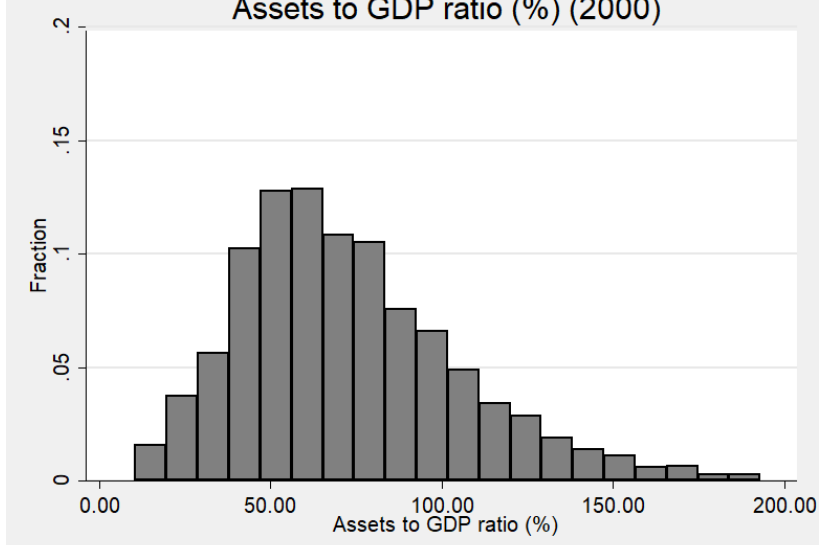

Assets to GDP ratio (\%) (2010)

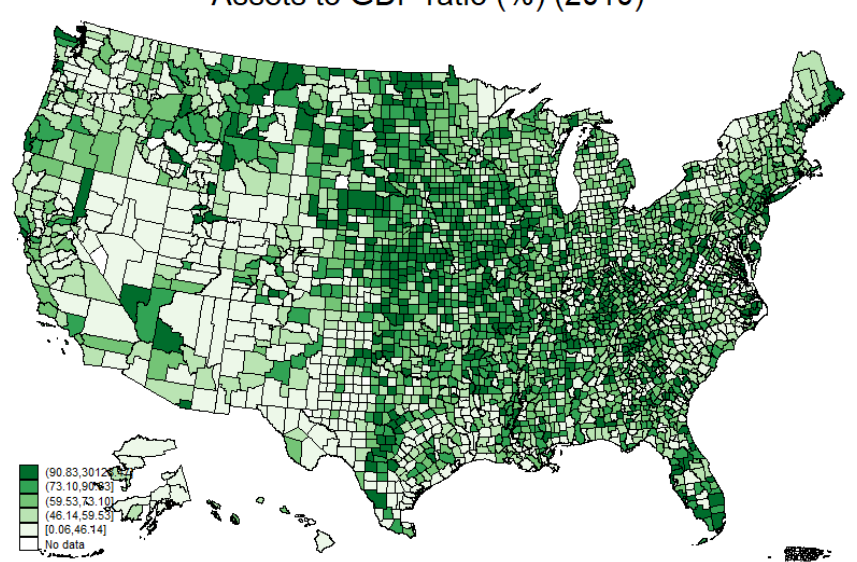

Assets to GDP ratio (\%) (2010)

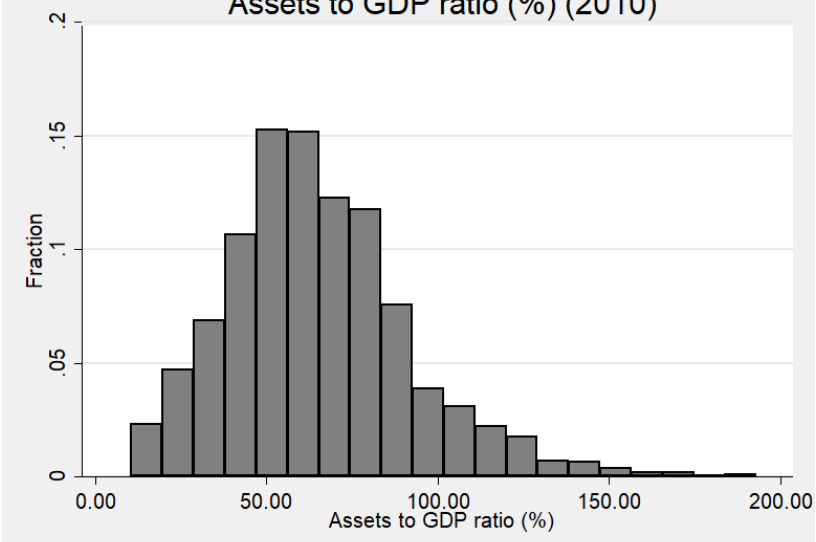

Assets to GDP ratio (\%) (2019)

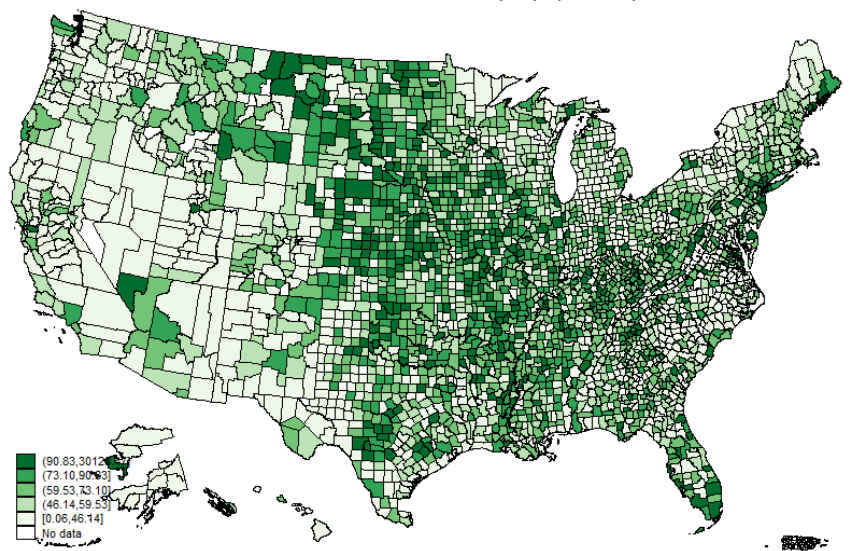

Assets to GDP ratio (\%) (2019)

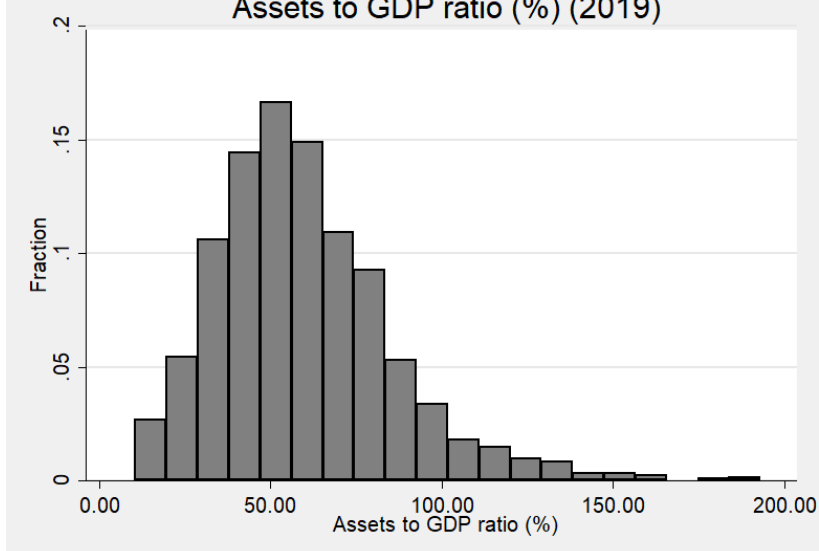

Note: This figure illustrates the average bank assets to GDP ratios in each county and its distribution in 1990, 2000, 2010 and 2019. Brackets for the maps are based on quintiles in the year 2005. A darker area represents larger ratio in one particular county. The histogram represents the fraction of counties that fall into the range of one bar (width is equal to $10.57 \%$., starting at value $9.13 \%)$. Outliers $(<1 \%$-percentile or $>99 \%$-percentile using all data points) are excluded for the histograms. Please see the Online Appendix for a dynamic representation of the maps and histograms for all years. 
Figure C10: Share of agricultural loans (\%)
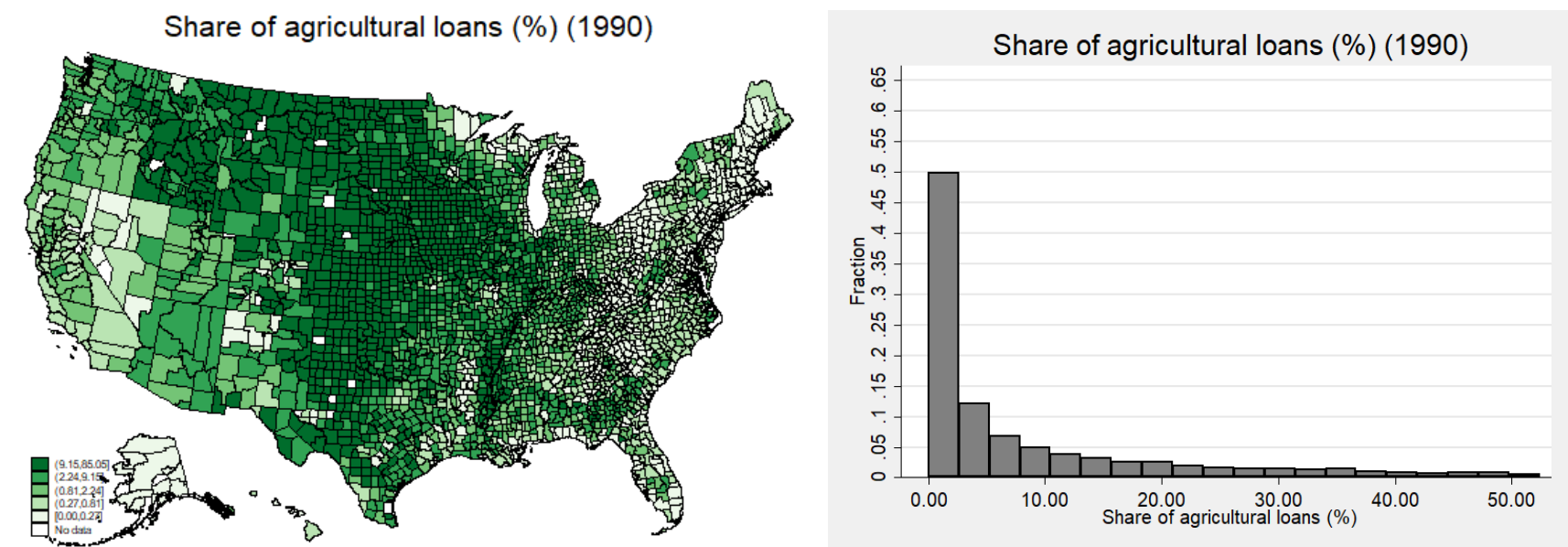

Share of agricultural loans (\%) (2000)

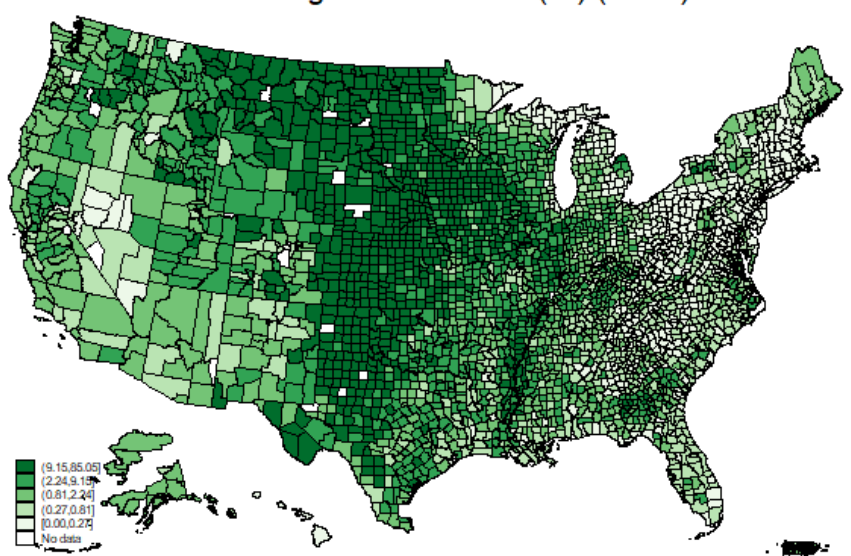

Share of agricultural loans (\%) (2000)

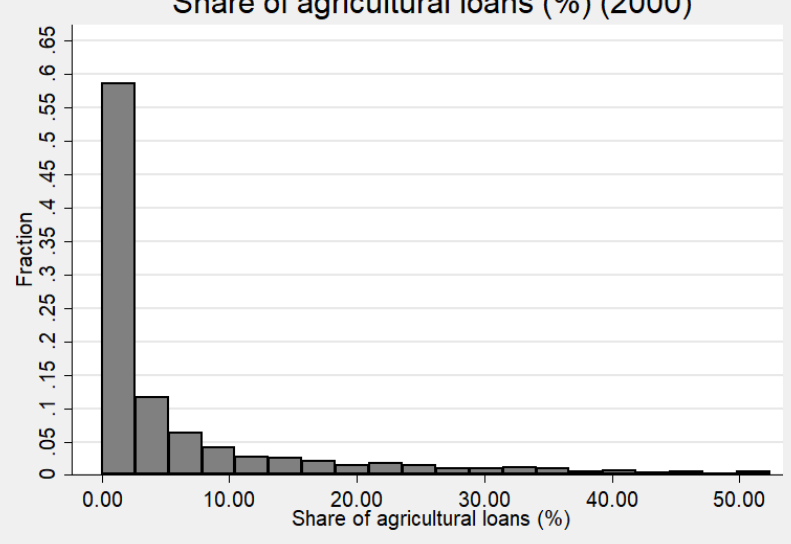

Share of agricultural loans (\%) (2010)

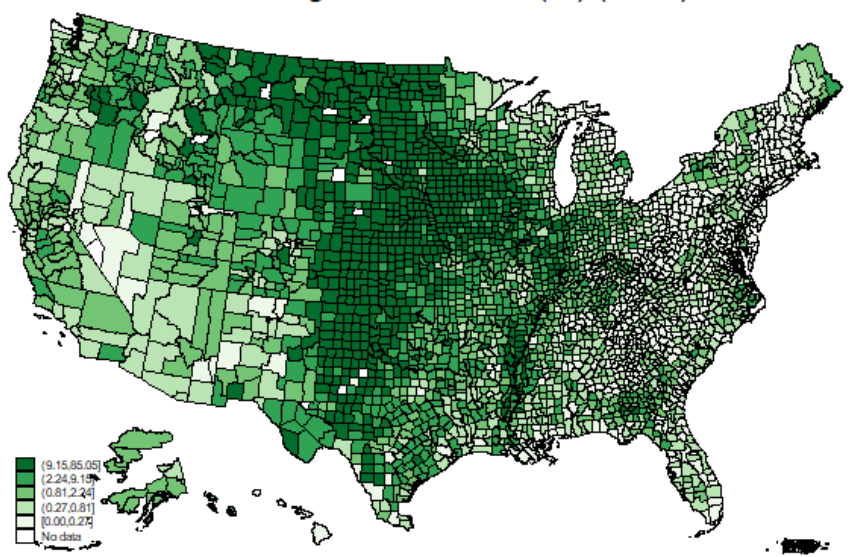

Share of agricultural loans (\%) (2010)

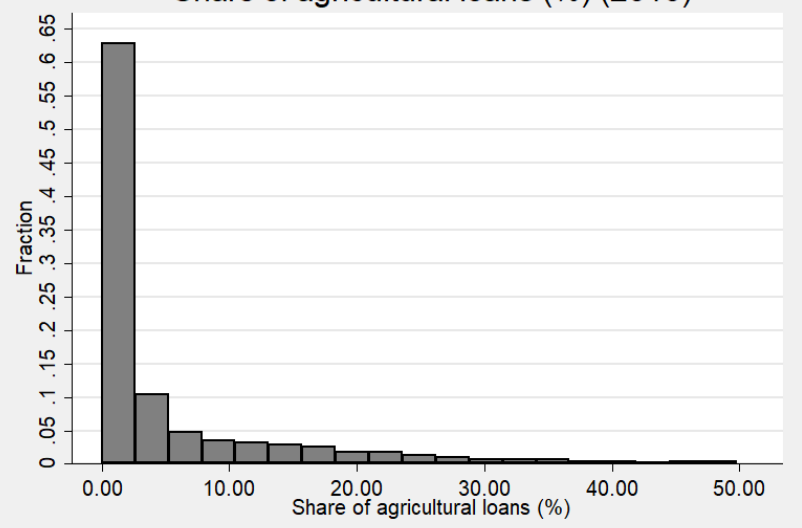

Share of agricultural loans (\%) (2019)

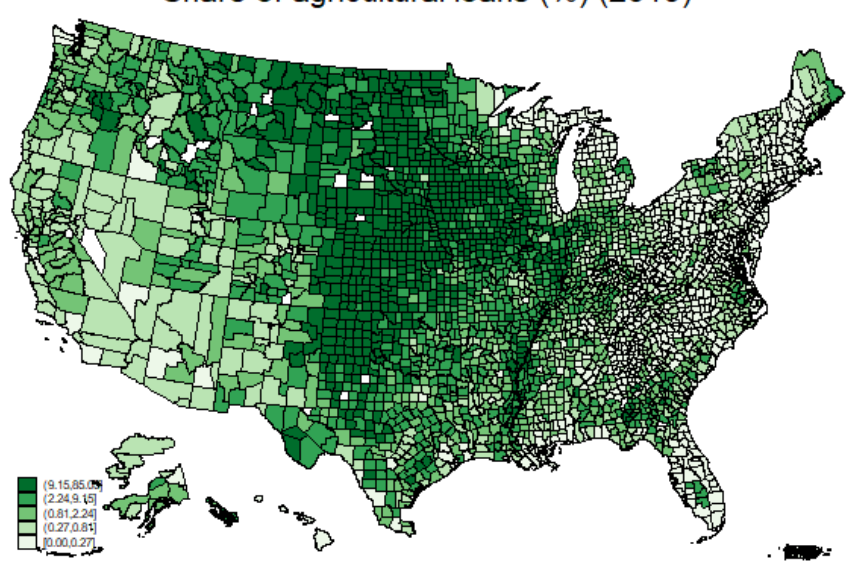

Share of agricultural loans (\%) (2019)

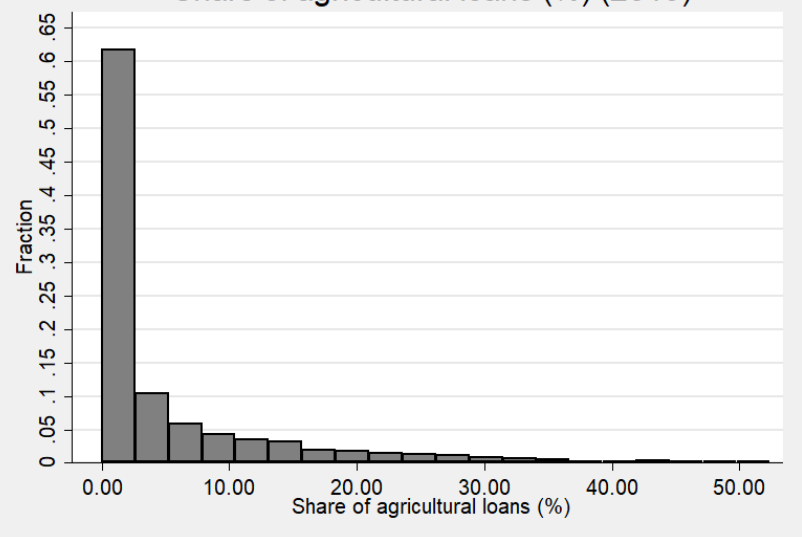

Note: This figure illustrates the share of agricultural loans in each county and its distribution in 1990, 2000, 2010 and 2019. Brackets for the maps are based on quintiles in the year 2005. A darker area represents a larger share in one particular county. The histogram represents the fraction of counties that fall into the range of one bar (width is equal to $2.62 \%$, starting at value $0 \%$ ). Outliers $(<1 \%$-percentile or $>99 \%$ percentile using all data points) are excluded for the histograms. Please see the Online Appendix for a dynamic representation of the maps and histograms for all years. 
Figure C11: Share of commercial and industrial loans (\%)

Share of commercial and industrial loans (\%) (1990)
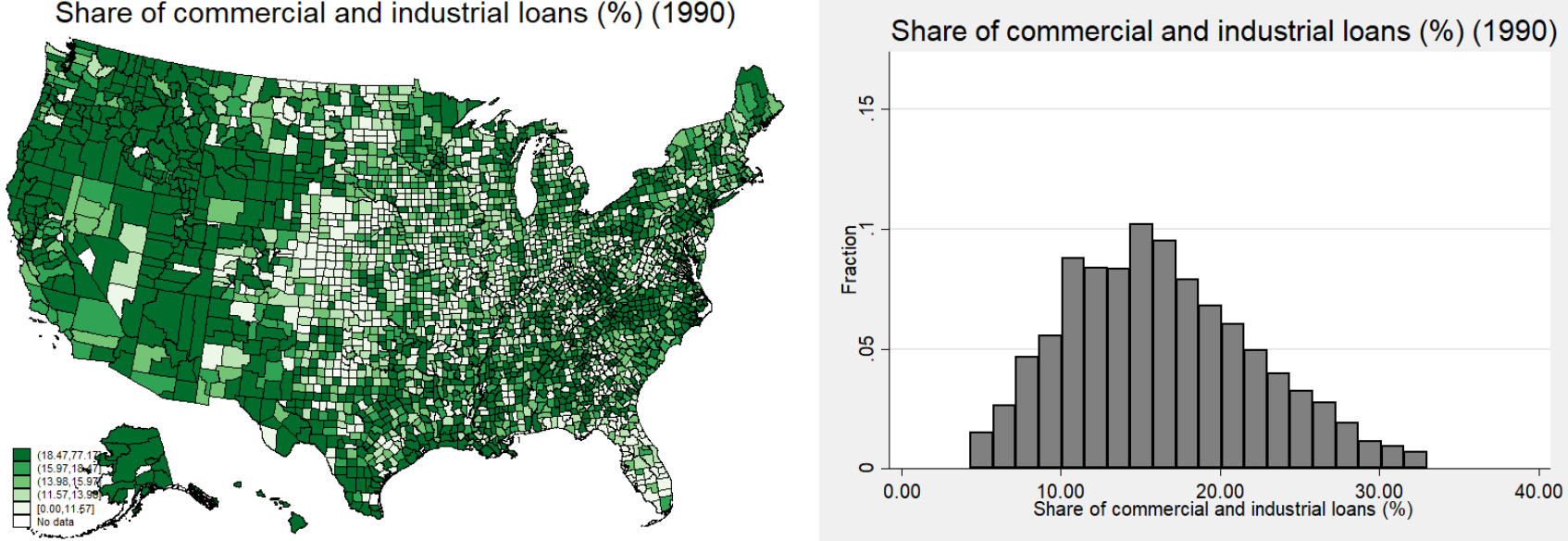

Share of commercial and industrial loans (\%) (2000)

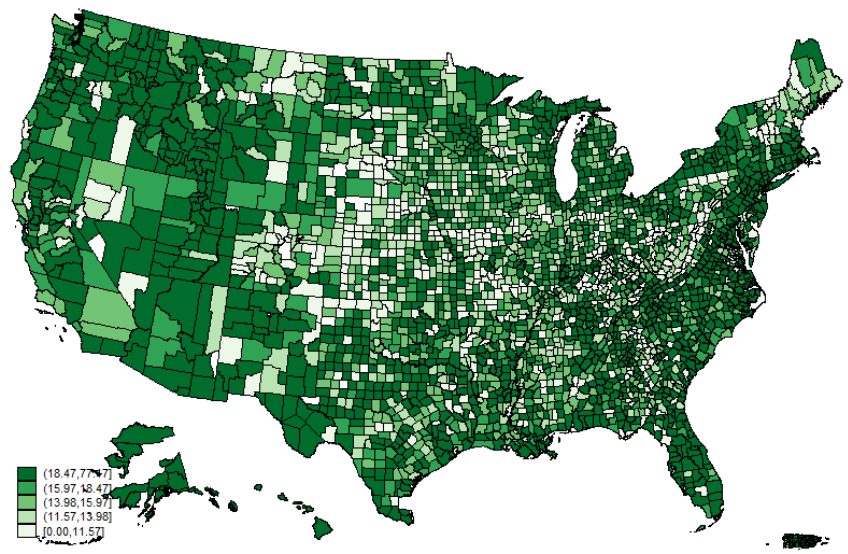

Share of commercial and industrial loans (\%) (2000)

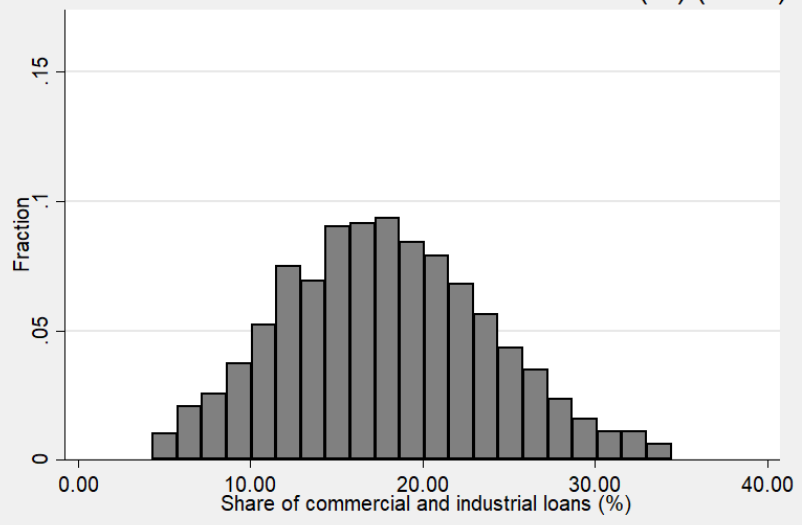

Share of commercial and industrial loans (\%) (2010)

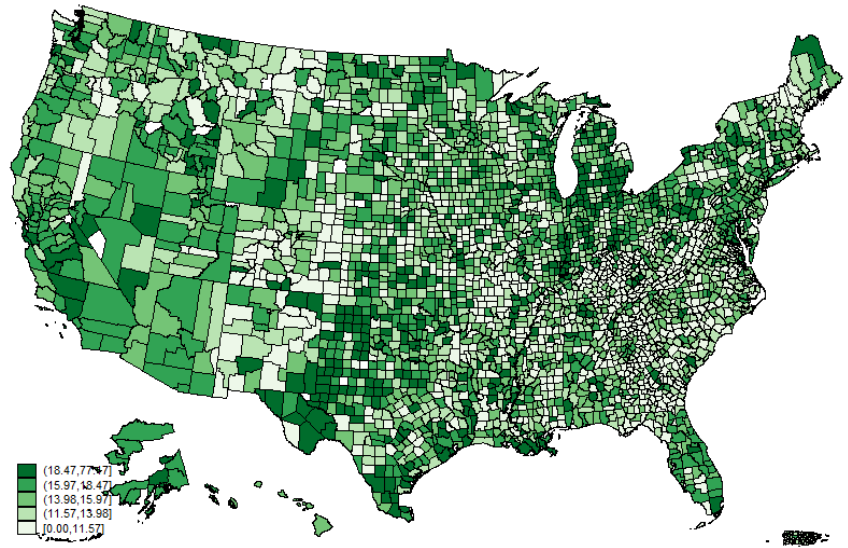

Share of commercial and industrial loans (\%) (2010)

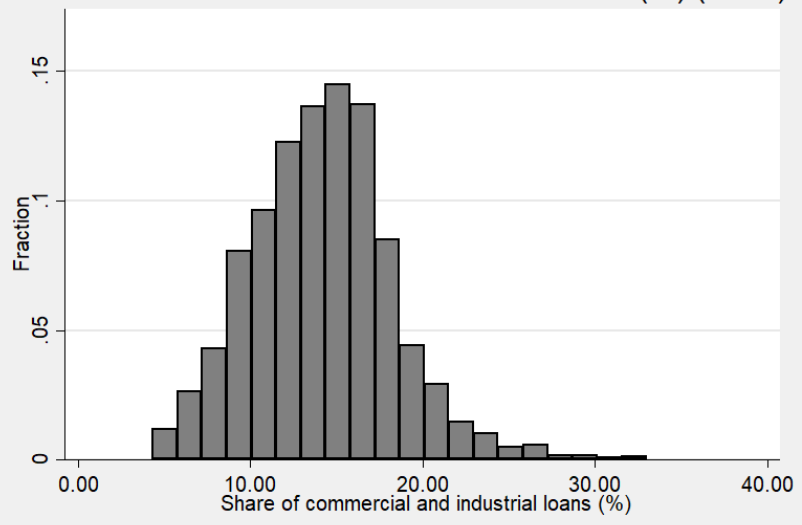

Share of commercial and industrial loans (\%) (2019)

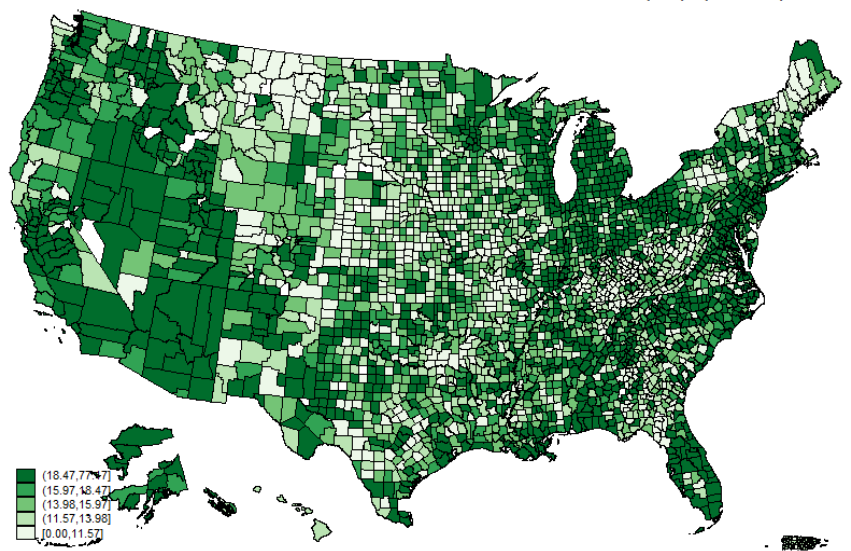

Share of commercial and industrial loans (\%) (2019)

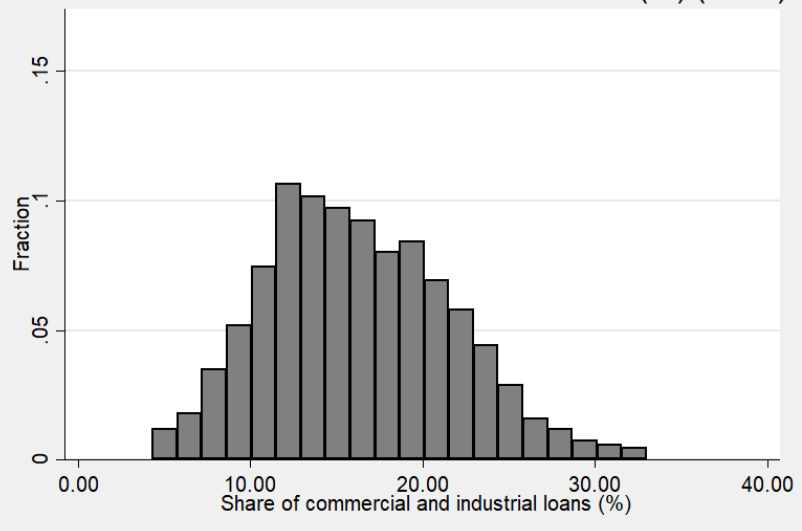

Note: This figure illustrates the share of commercial and industrial loans in each county and its distribution in 1990, 2000,2010 and 2019. Brackets for the maps are based on quintiles in the year 2005. A darker area represents a larger share in one particular county. The histogram represents the fraction of counties that fall into the range of one bar (width is equal to $1.43 \%$, starting at value $4.35 \%)$. Outliers ( $<1 \%$ percentile or $>99 \%$-percentile using all data points) are excluded for the histograms. Please see the Online Appendix for a dynamic representation of the maps and histograms for all years. 
Figure C12: Share of commercial and industrial loans below \$1 mio (\%)
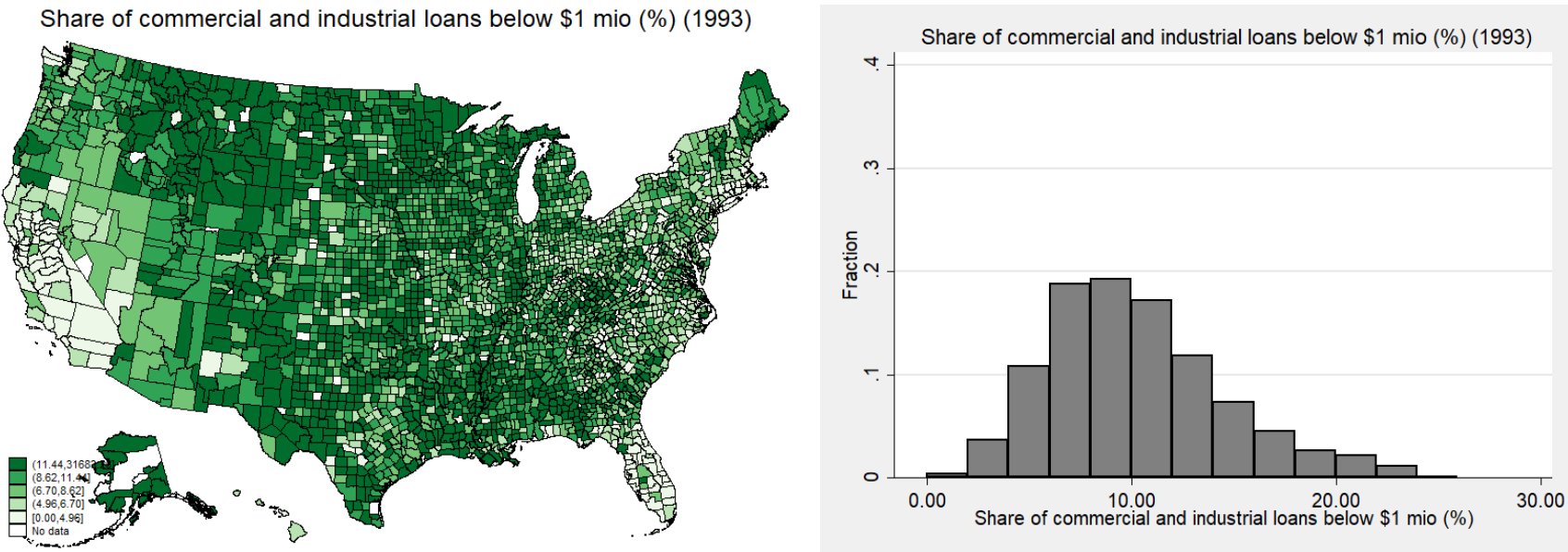

Share of commercial and industrial loans below $\$ 1$ mio (\%) (2000)
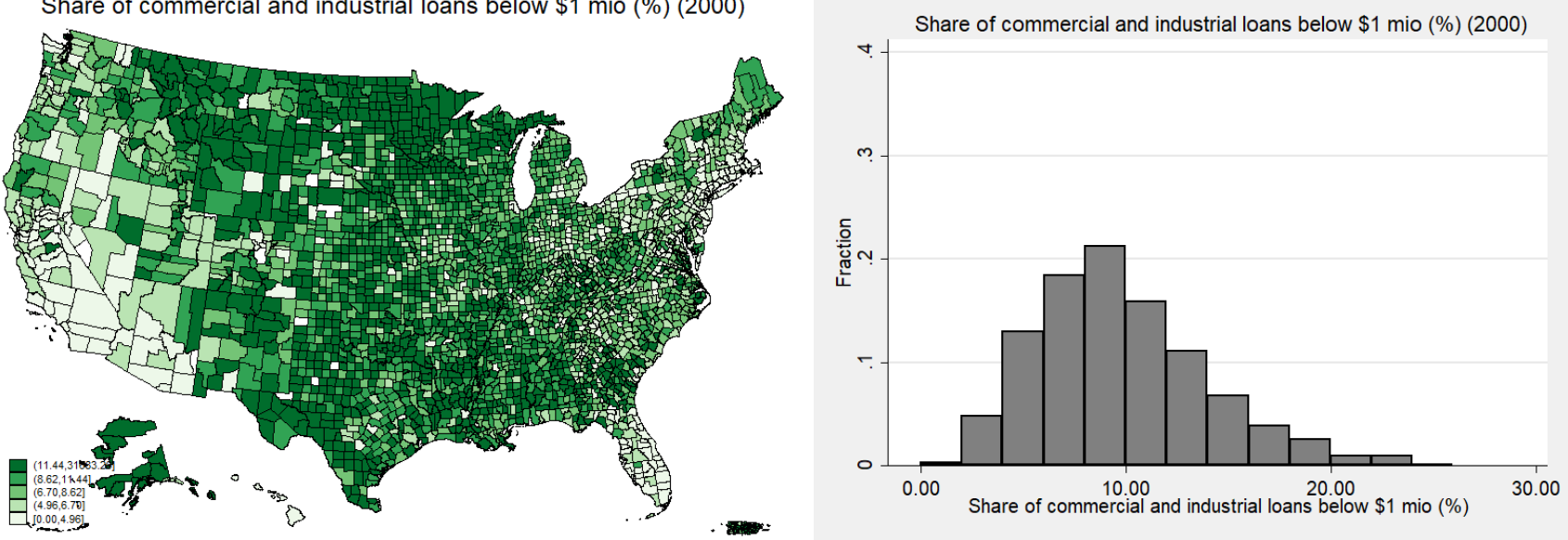

Share of commercial and industrial loans below $\$ 1$ mio (\%) (2010)
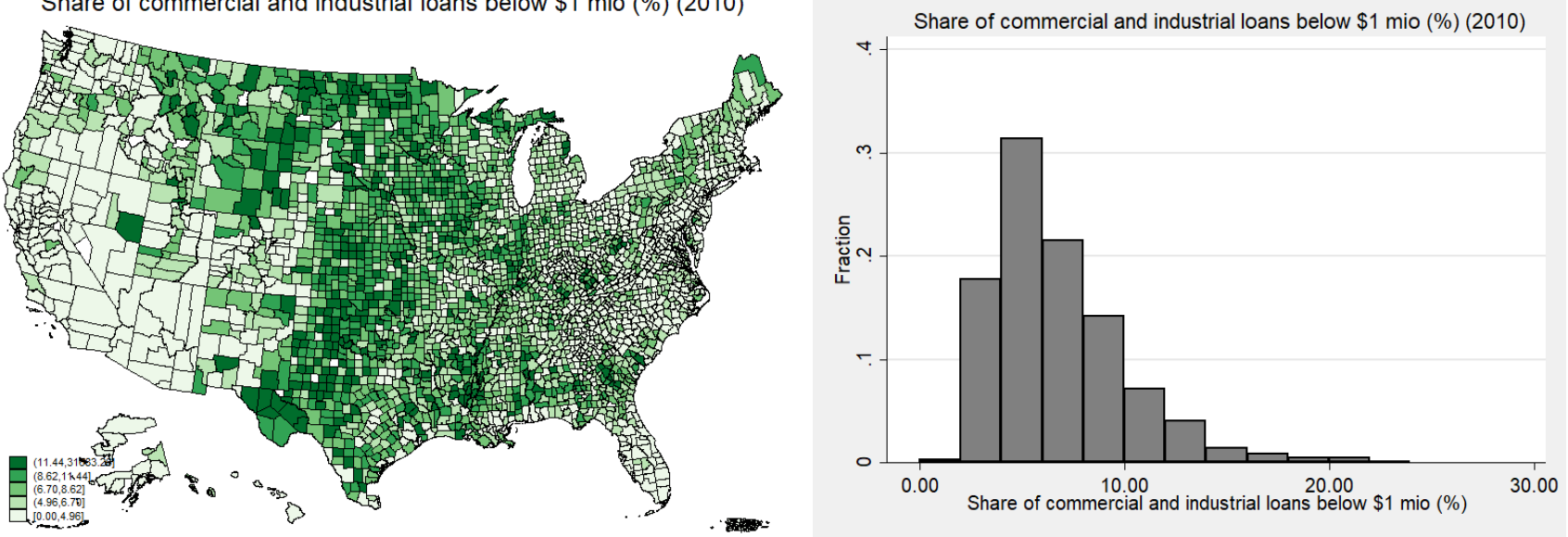

Share of commercial and industrial loans below $\$ 1$ mio (\%) (2019)
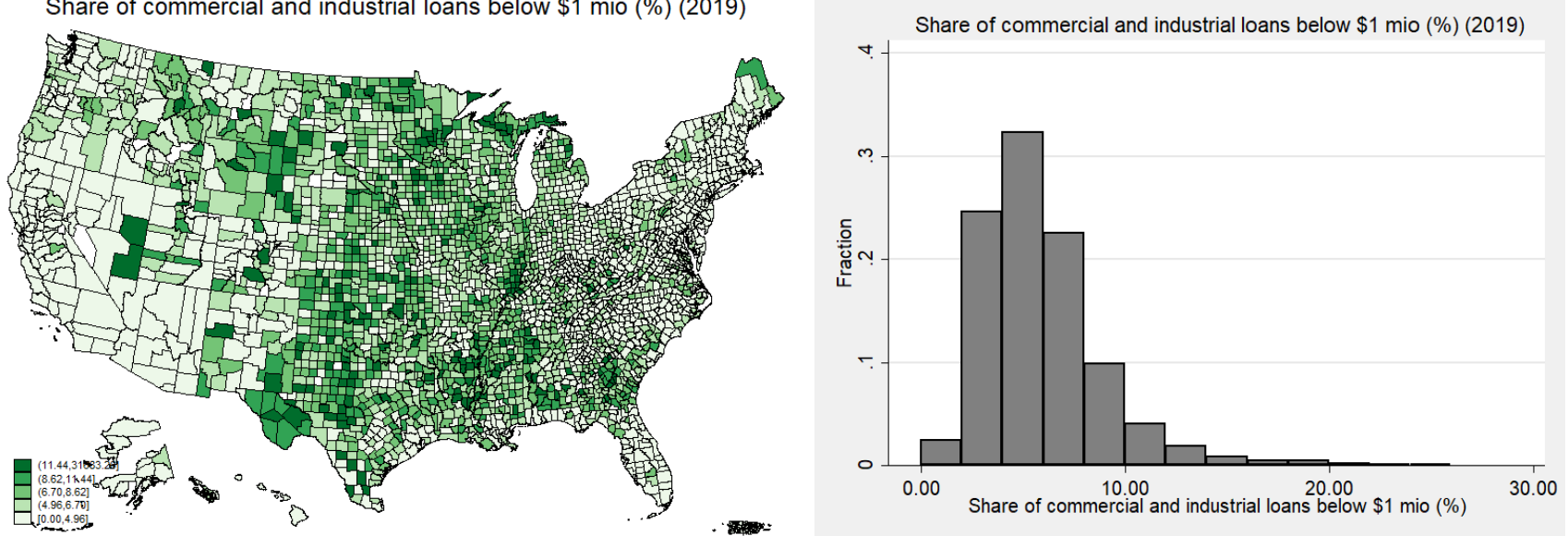

Note: This figure illustrates the share of commercial and industrial loans below \$1 mio. in each county and its distribution in 1993, 2000, 2010 and 2019. Data prior 1993 are not available. Brackets for the maps are based on quintiles in the year 2005. A darker area represents a larger share in one particular county. The histogram represents the fraction of counties that fall into the range of one bar (width is equal to $2 \%$, starting at value $0 \%)$. Outliers ( $<1 \%$-percentile or $>99 \%$-percentile using all data points) are excluded for the histograms. Please see the Online Appendix for a dynamic representation of the maps and histograms for all years. 


\section{Figure C13: Share of real estate loans (\%)}
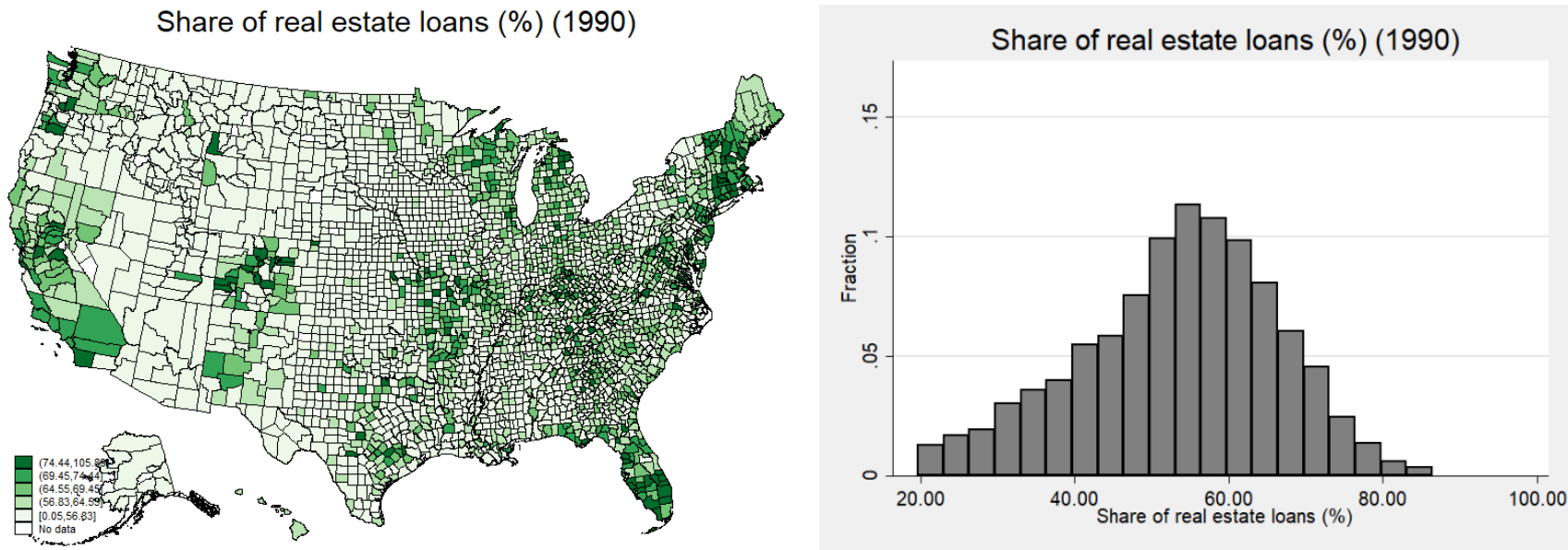

Share of real estate loans (\%) (2000)

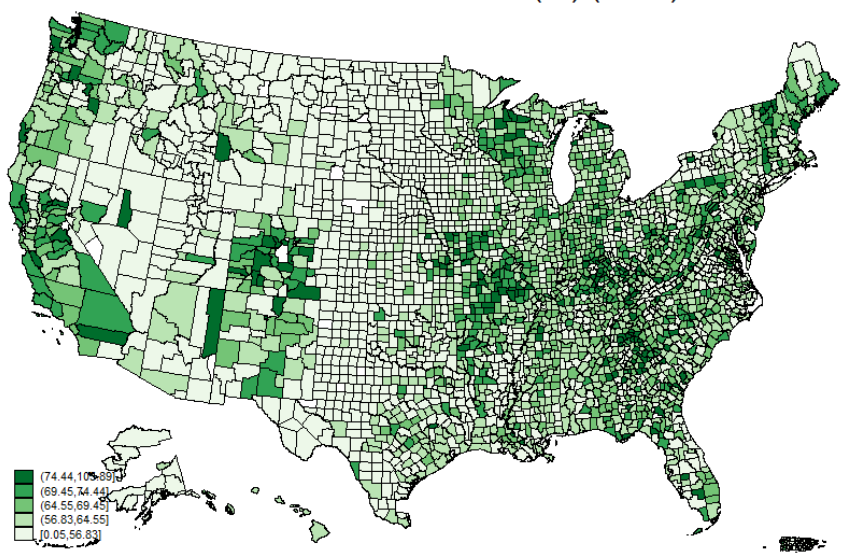

Share of real estate loans (\%) (2010)

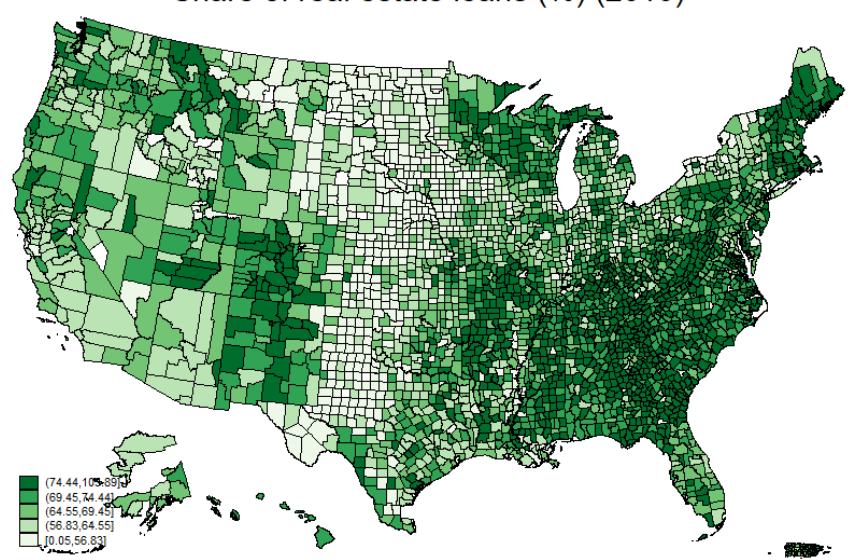

Share of real estate loans (\%) (2019)
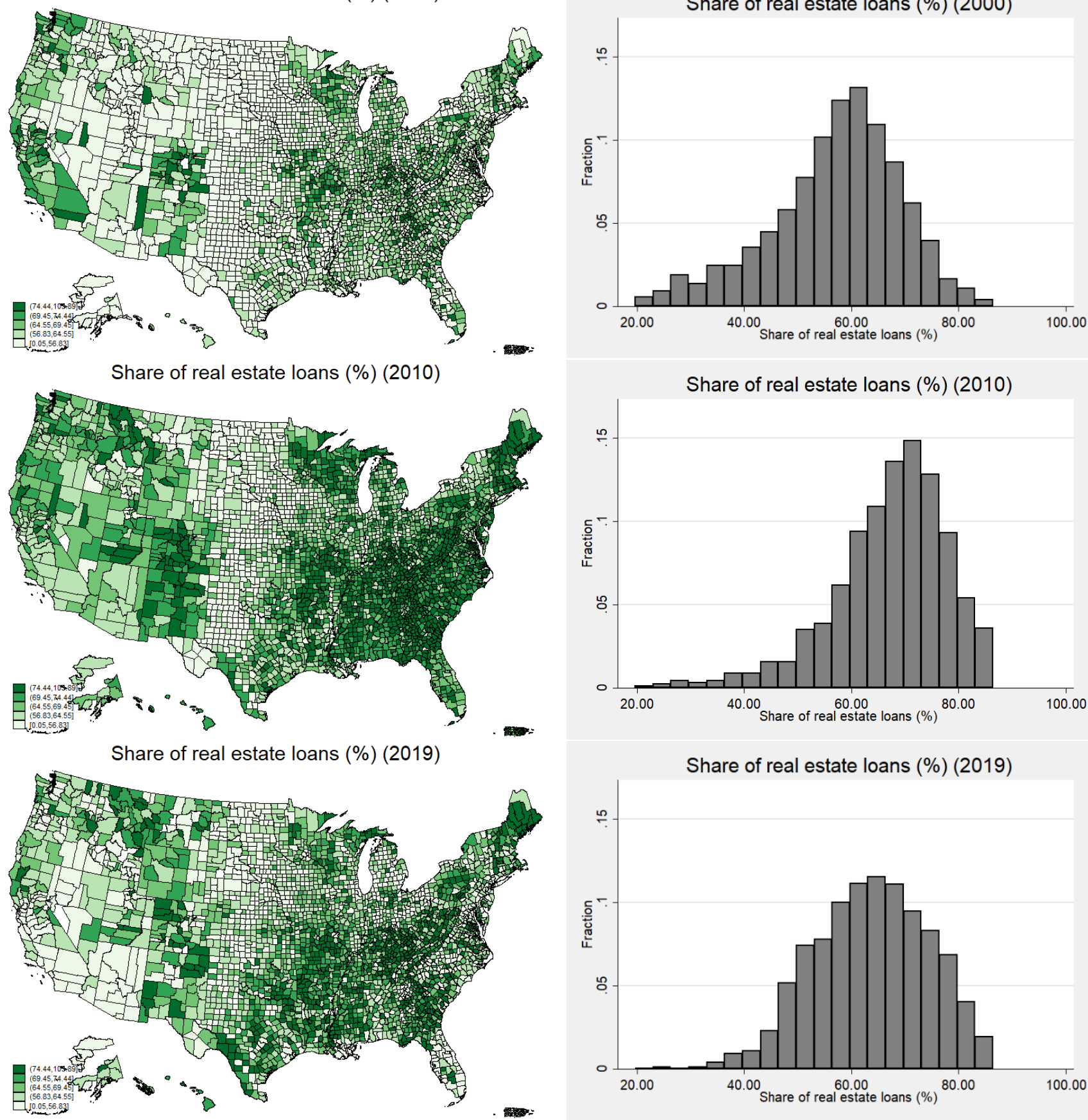

Share of real estate loans (\%) (2010)

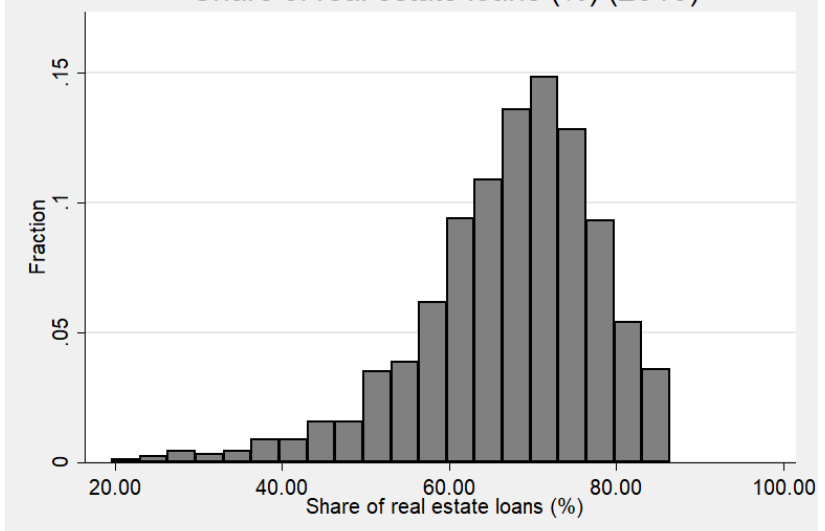

Share of real estate loans (\%) (2019)

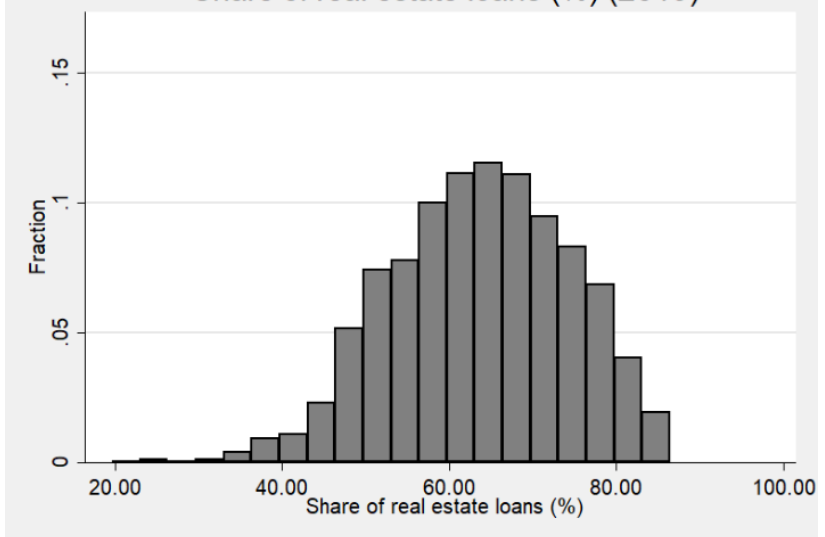

Note: This figure illustrates the share of real estate loans in each county and its distribution in 1990, 2000, 2010 and 2019. Brackets for the maps are based on quintiles in the year 2005. A darker area represents a larger share in one particular county. The histogram represents the fraction of counties that fall into the range of one bar (width is equal to $3.34 \%$, starting at value $19.67 \%)$. Outliers $(<1 \%$-percentile or $>99 \%$ percentile using all data points) are excluded for the histograms. Please see the Online Appendix for a dynamic representation of the maps and histograms for all years. 
Figure C14: Non-interest income to asset ratio (\%)
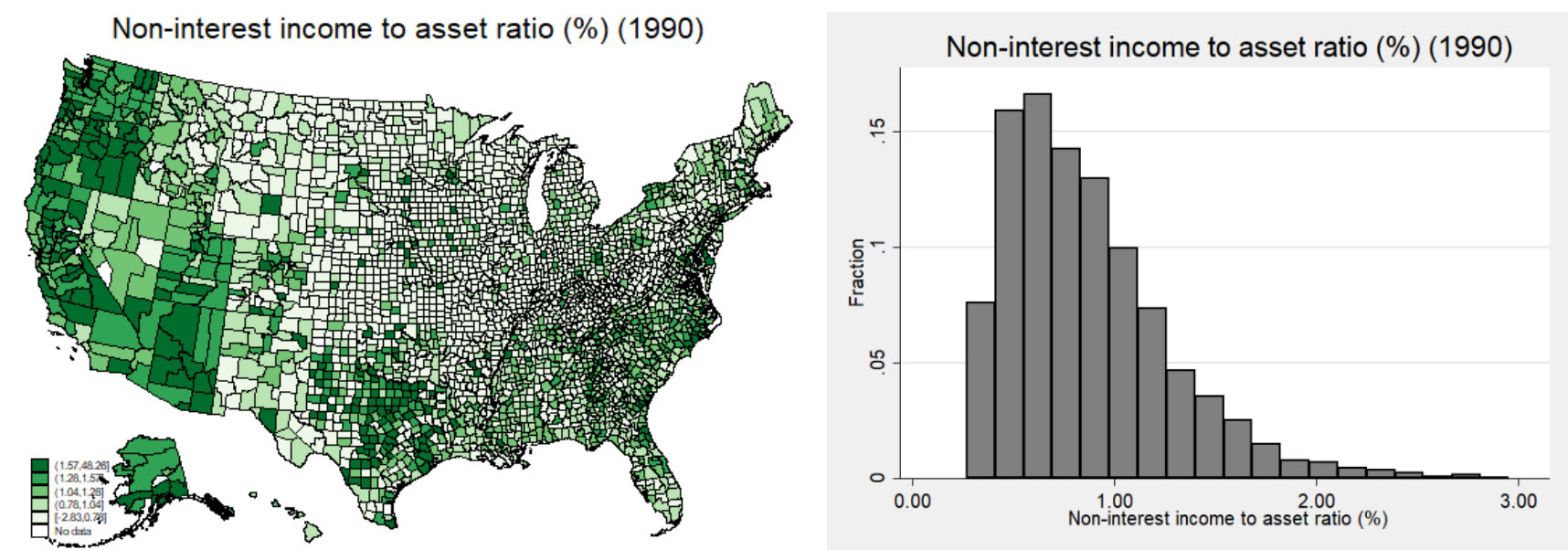

Non-interest income to asset ratio (\%) (2000)

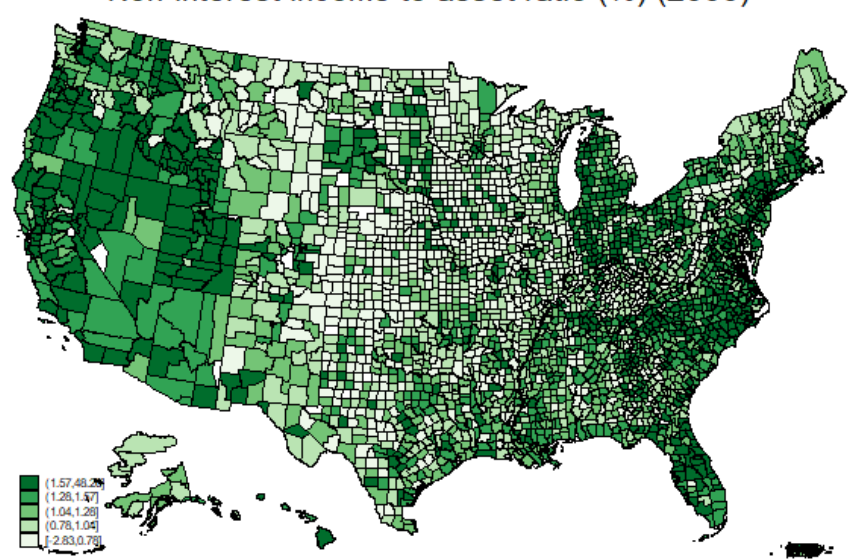

Non-interest income to asset ratio (\%) (2000)

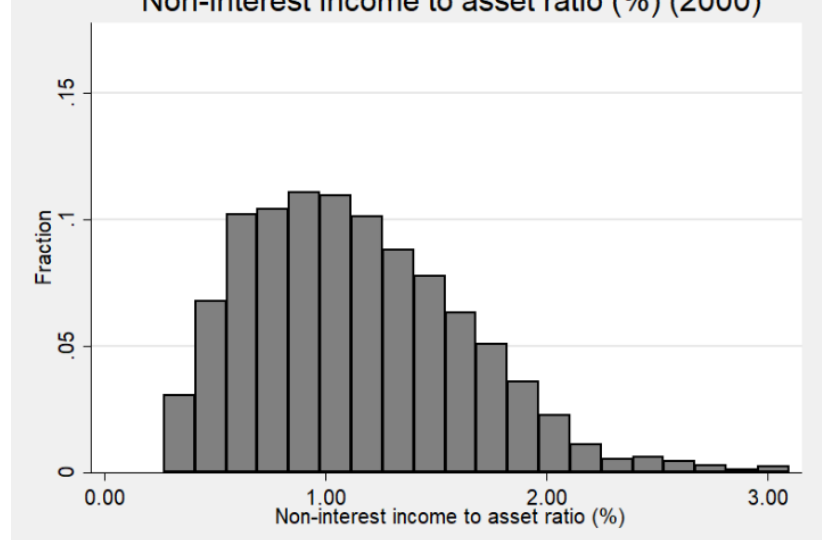

Non-interest income to asset ratio (\%) (2010)

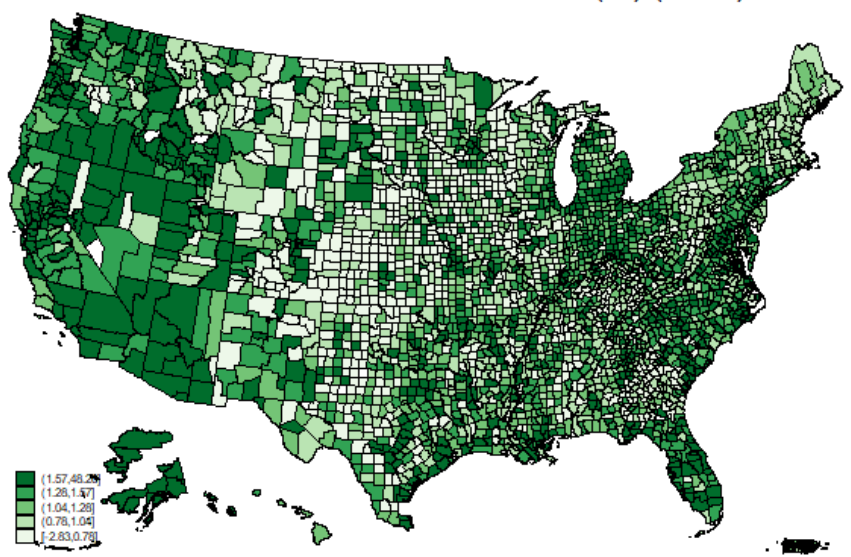

Non-interest income to asset ratio (\%) (2010)

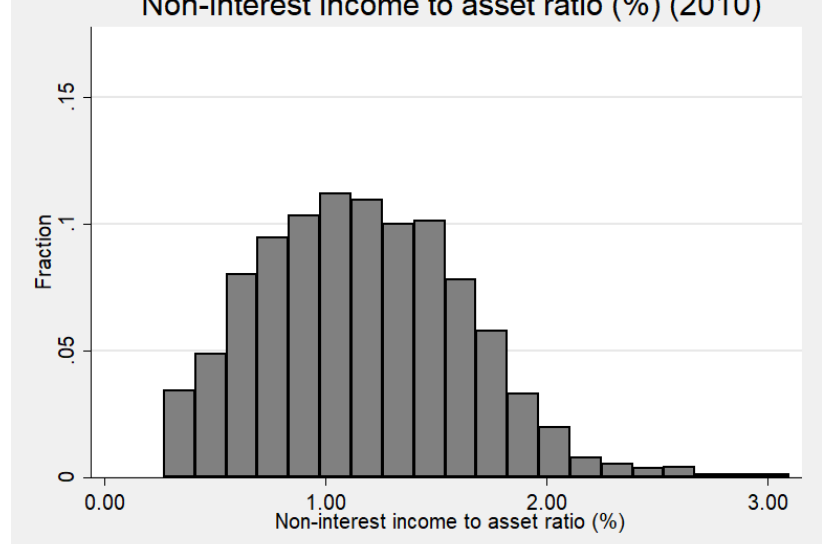

Non-interest income to asset ratio (\%) (2019)

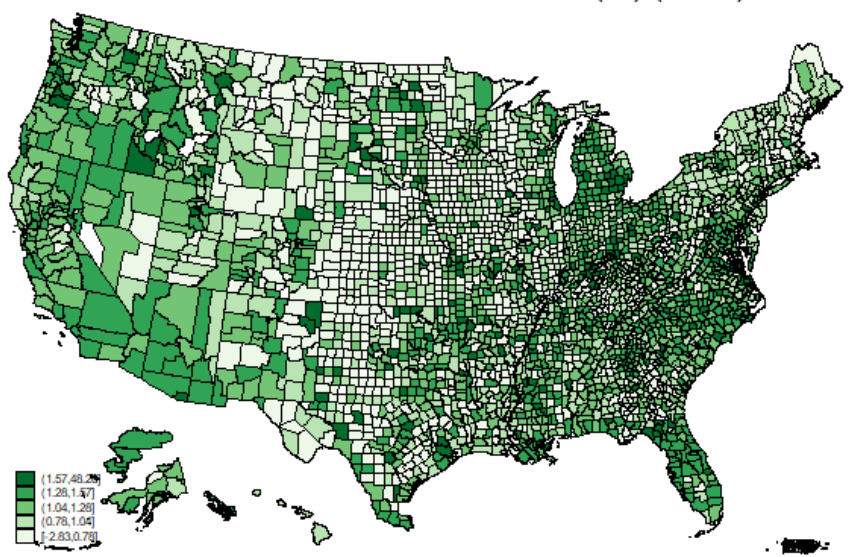

Non-interest income to asset ratio (\%) (2019)

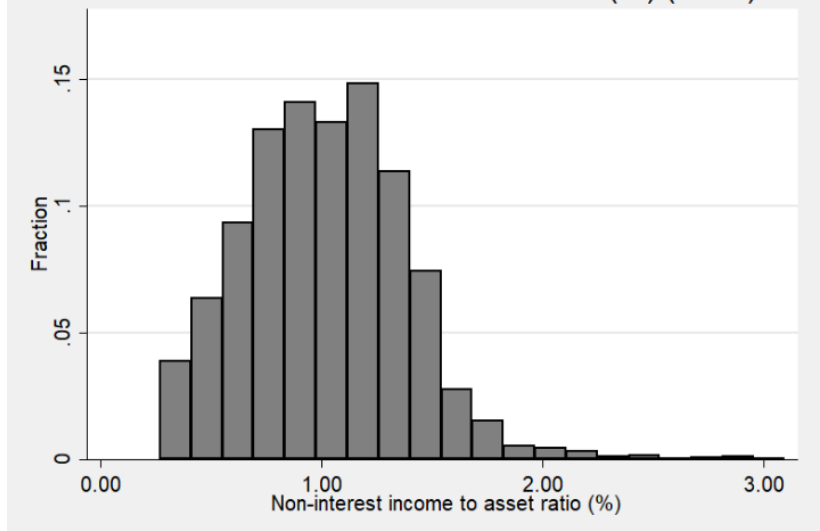

Note: This figure illustrates the non-interest income to asset ratios in each county and its distribution in 1990, 2000, 2010 and 2019. Brackets for the maps are based on quintiles in the year 2005. A darker area represents a larger ratio in one particular county. The histogram represents the fraction of counties that fall into the range of one bar (width is equal to $0.14 \%$, starting at value $0.27 \%$ ). Outliers $(<1 \%$-percentile or $>99 \%$ percentile using all data points) are excluded for the histograms. Please see the Online Appendix for a dynamic representation of the maps and histograms for all years. 
Figure C15: Common Equity Tier 1 ratio (\%)
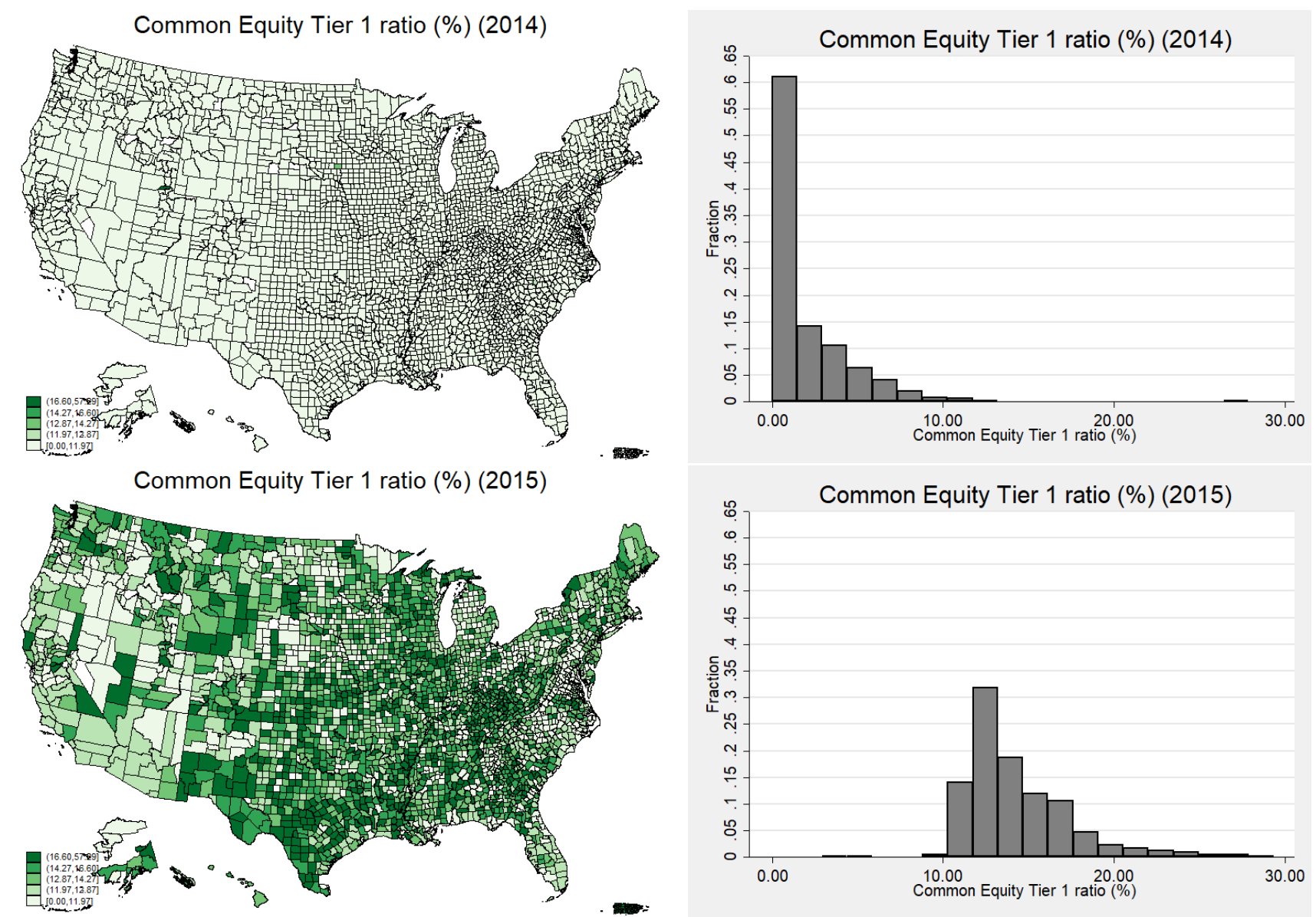

Common Equity Tier 1 ratio (\%) (2017)
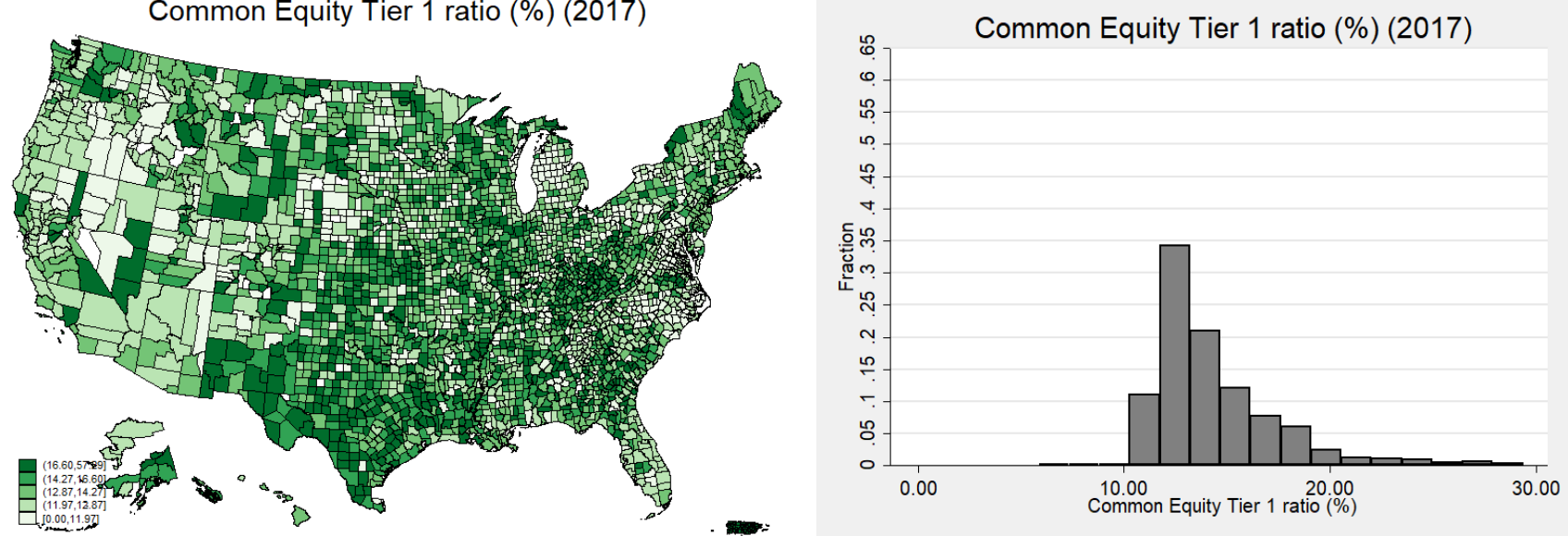

Common Equity Tier 1 ratio (\%) (2019)
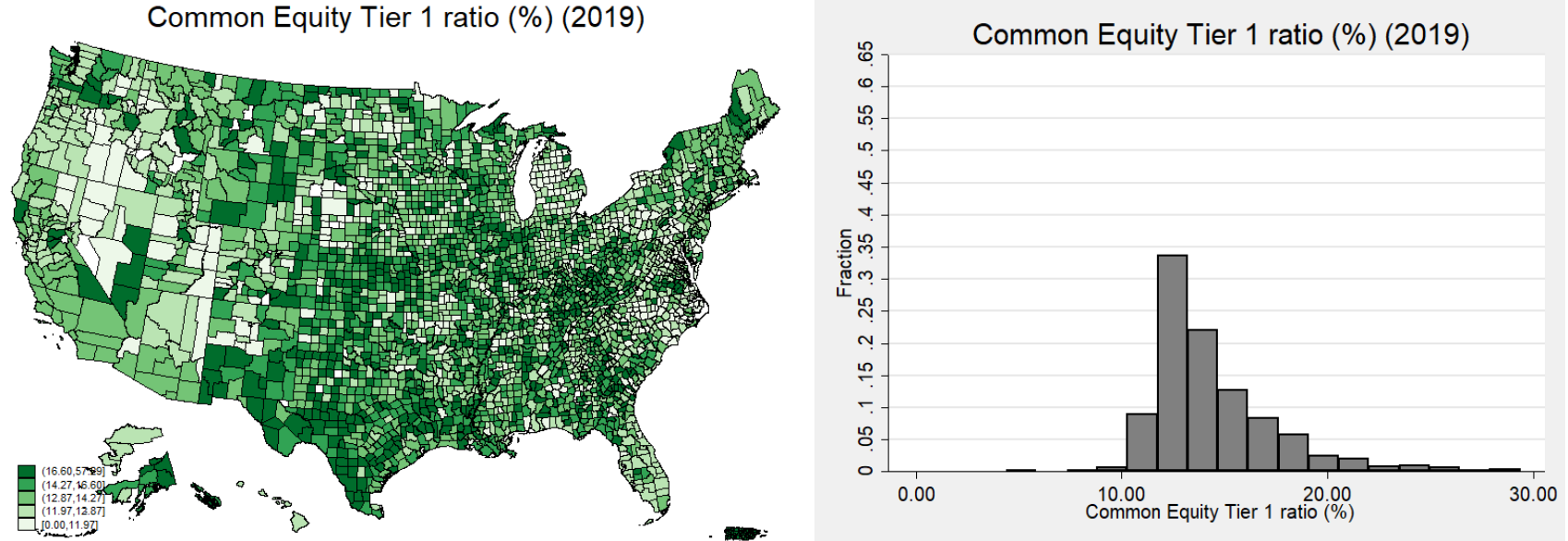

Note: This figure illustrates the Common Equity Tier 1 ratio across banks in each county and its distribution in 2014, 2015, 2017 and 2019. Data prior 2014 is not available. Brackets for the maps are based on quintiles in the year 2015. A darker area represents larger ratio in one particular county. The histogram represents the fraction of counties that fall into the range of one bar (width is equal to $1.47 \%$, starting at value $0 \%$ ). Outliers (<1\%-percentile or $>99 \%$-percentile using all data points) are excluded for the histograms. Please see the Online Appendix for a dynamic representation of the maps and histograms for all years. 

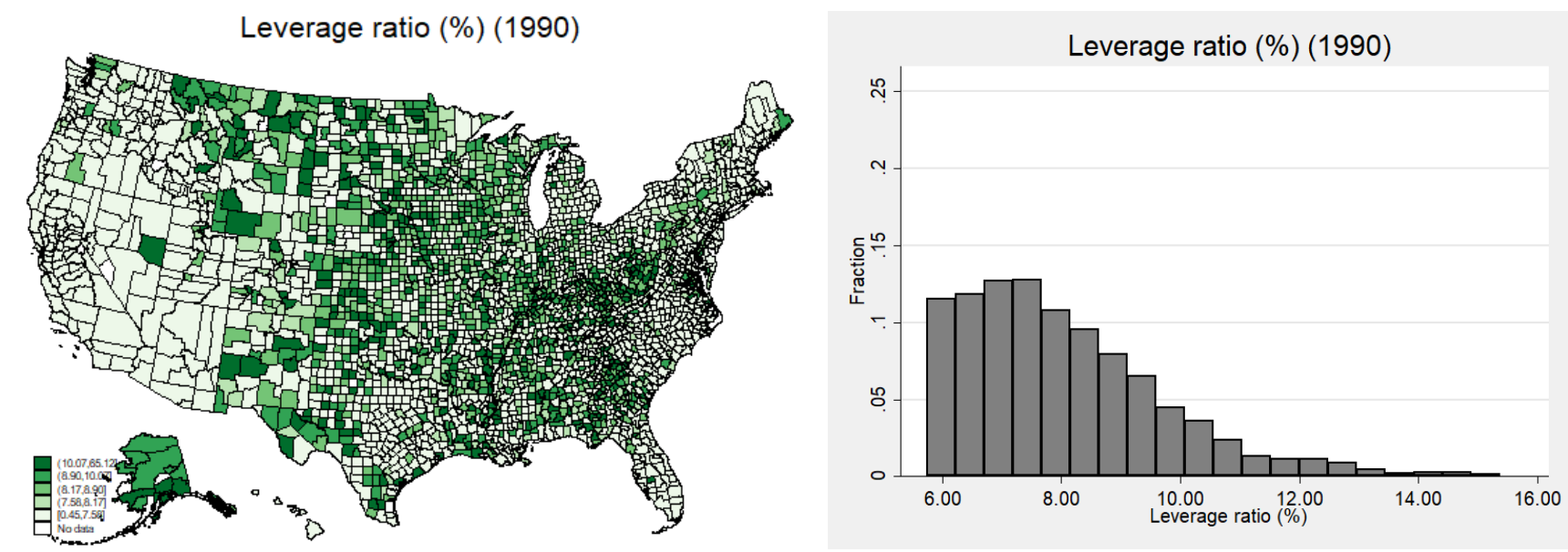

Leverage ratio (\%) (2000)

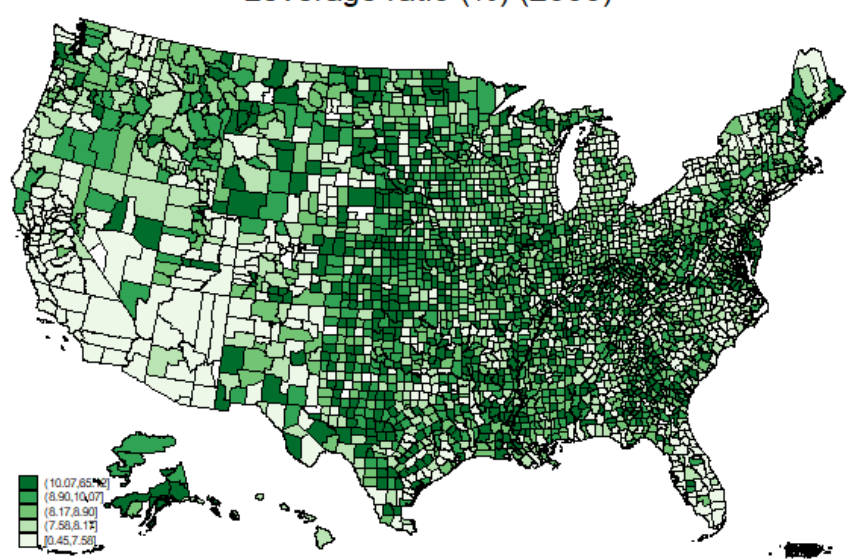

Leverage ratio (\%) (2000)

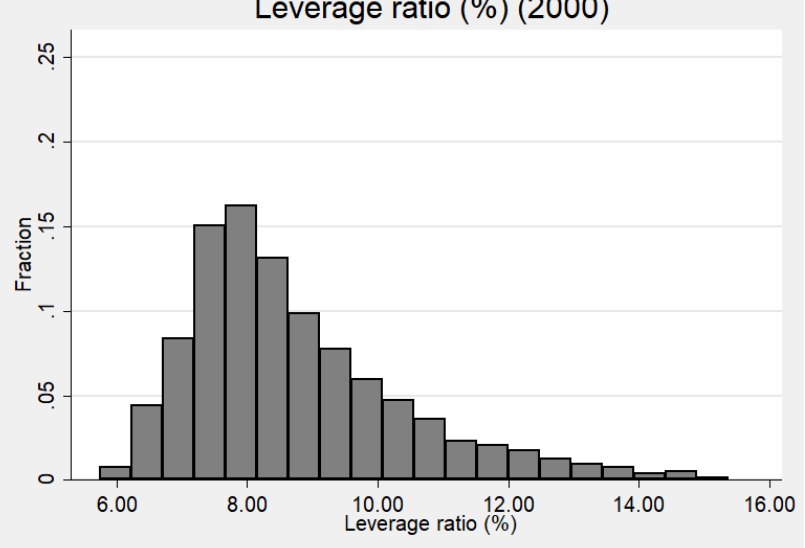

Leverage ratio (\%) (2010)

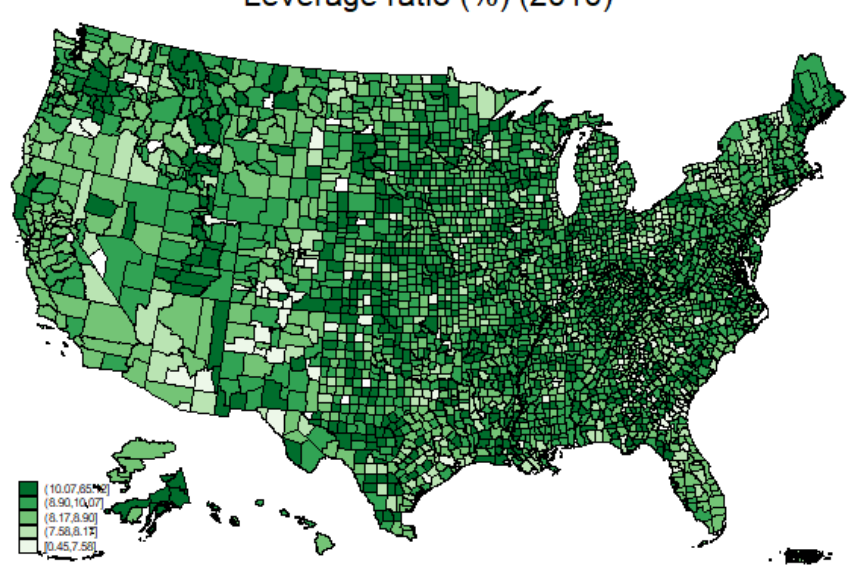

Leverage ratio (\%) (2019)
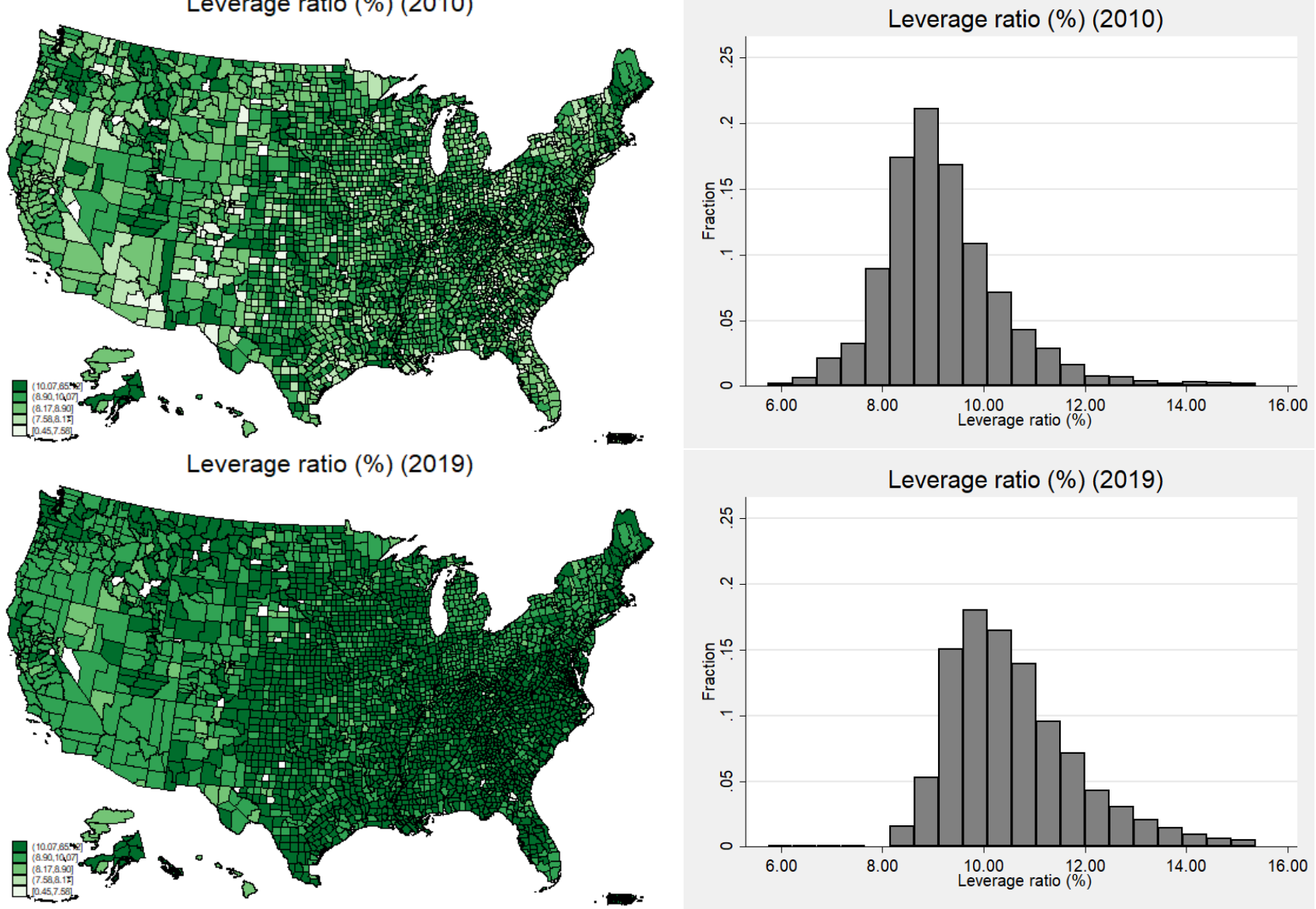

Leverage ratio (\%) (2019)

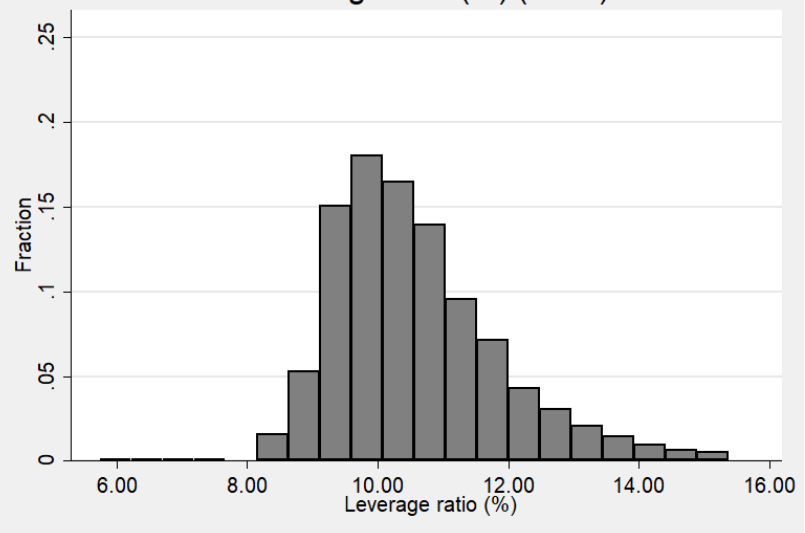

Note: This figure illustrates the average (inverted) Leverage ratio across banks in each county and its distribution in 1990, 2000,2010 and 2019. Brackets for the maps are based on quintiles in the year 2005. A darker area represents larger ratio in one particular county. The histogram represents the fraction of counties that fall into the range of one bar (width is equal to $0.48 \%$, starting at value $5.75 \%$ ). Outliers ( $<1 \%$-percentile or $>99 \%$-percentile using all data points) are excluded for the histograms. Please see the Online Appendix for a dynamic representation of the maps and histograms for all years. 

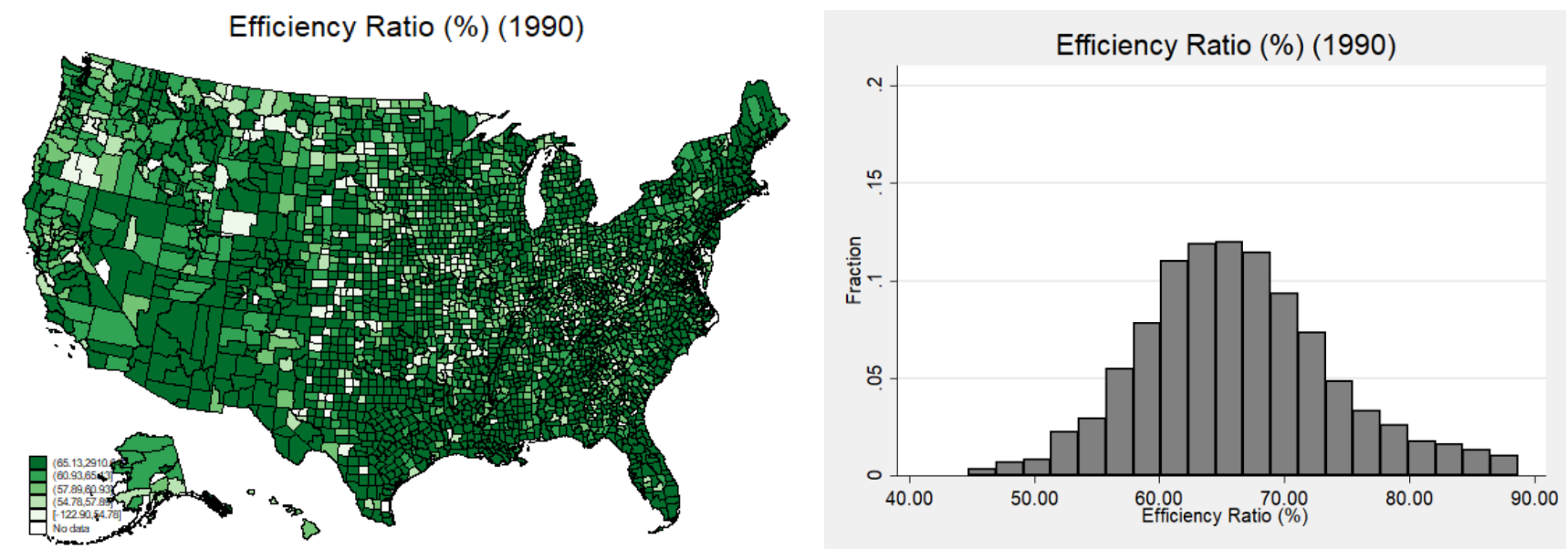

Efficiency Ratio (\%) (2000)
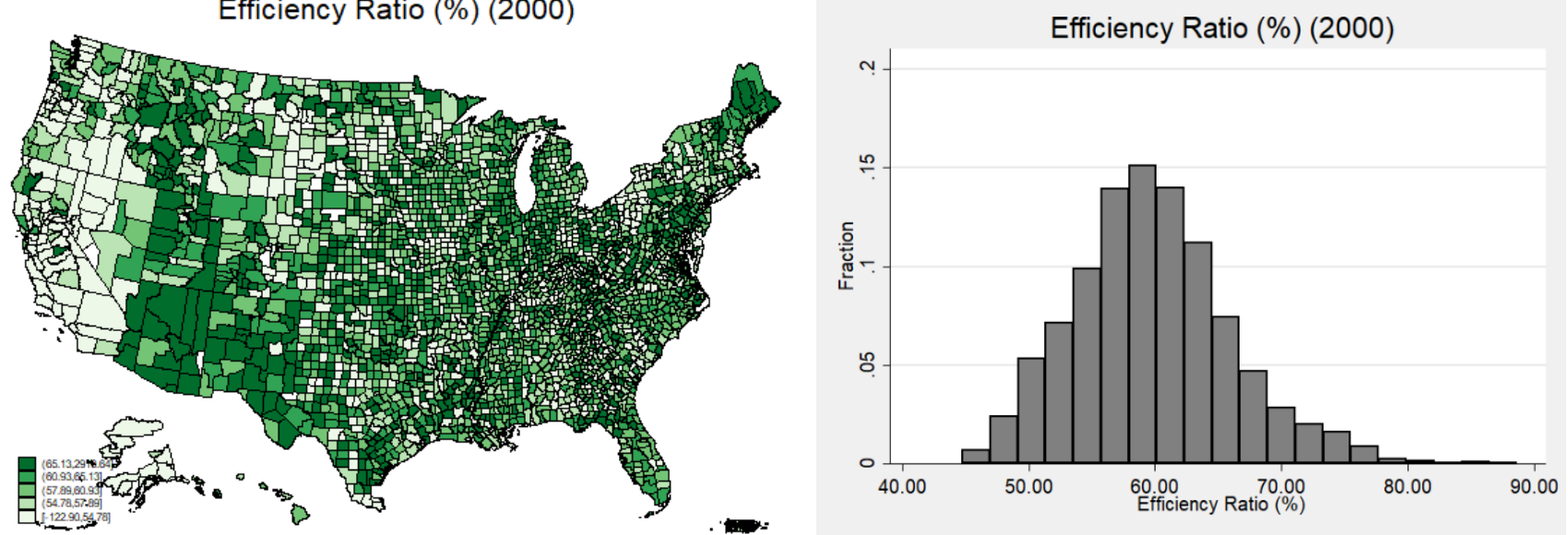

Efficiency Ratio (\%) (2010)
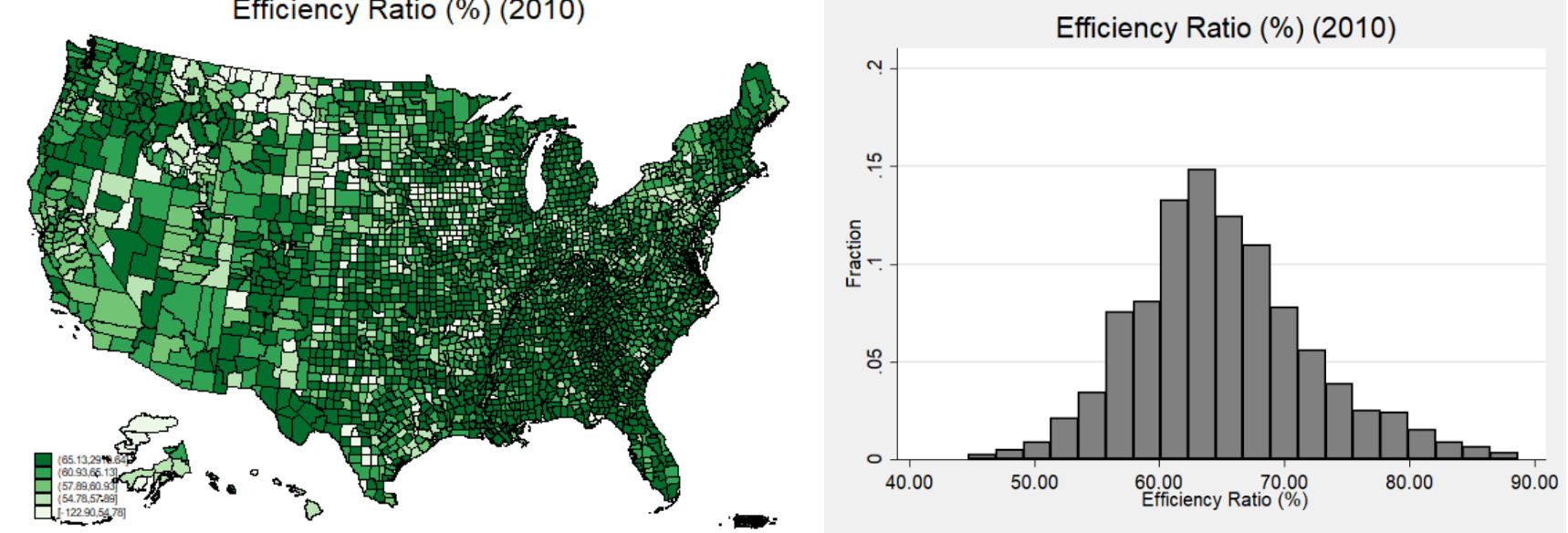

Efficiency Ratio (\%) (2019)
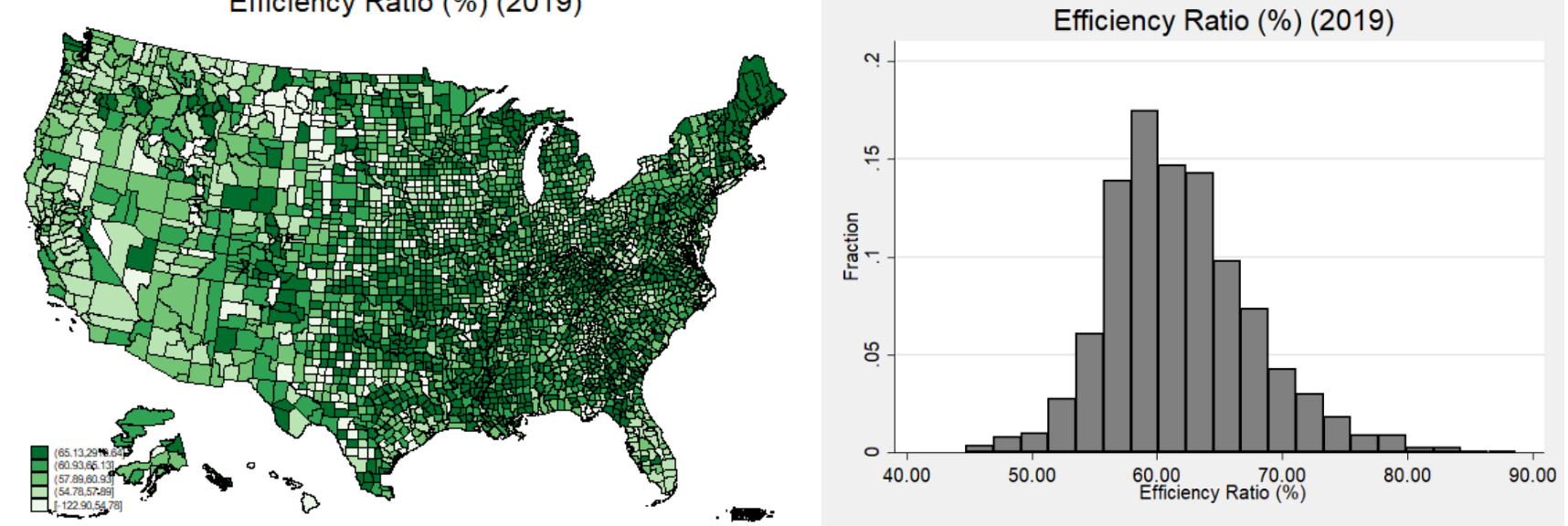

Note: This figure illustrates the average efficiency ratio across banks in each county and its distribution in 1990, 2000, 2010 and 2019. Brackets for the maps are based on quintiles in the year 2005. A darker area represents larger ratio in one particular county. The histogram represents the fraction of counties that fall into the range of one bar (width is equal to $2.19 \%$, starting at value $44.77 \%$ ). Outliers (<1\%-percentile or $>99 \%$ percentile using all data points) are excluded for the histograms. Please see the Online Appendix for a dynamic representation of the maps and histograms for all years. 

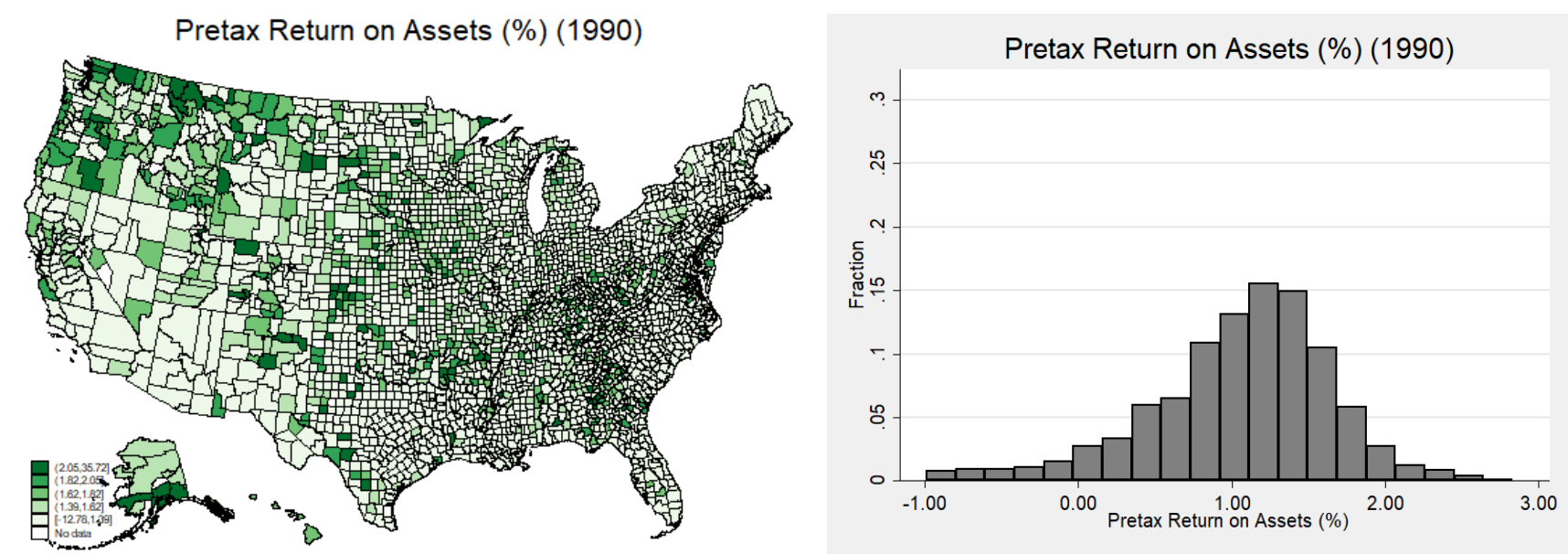

Pretax Return on Assets (\%) (2000)
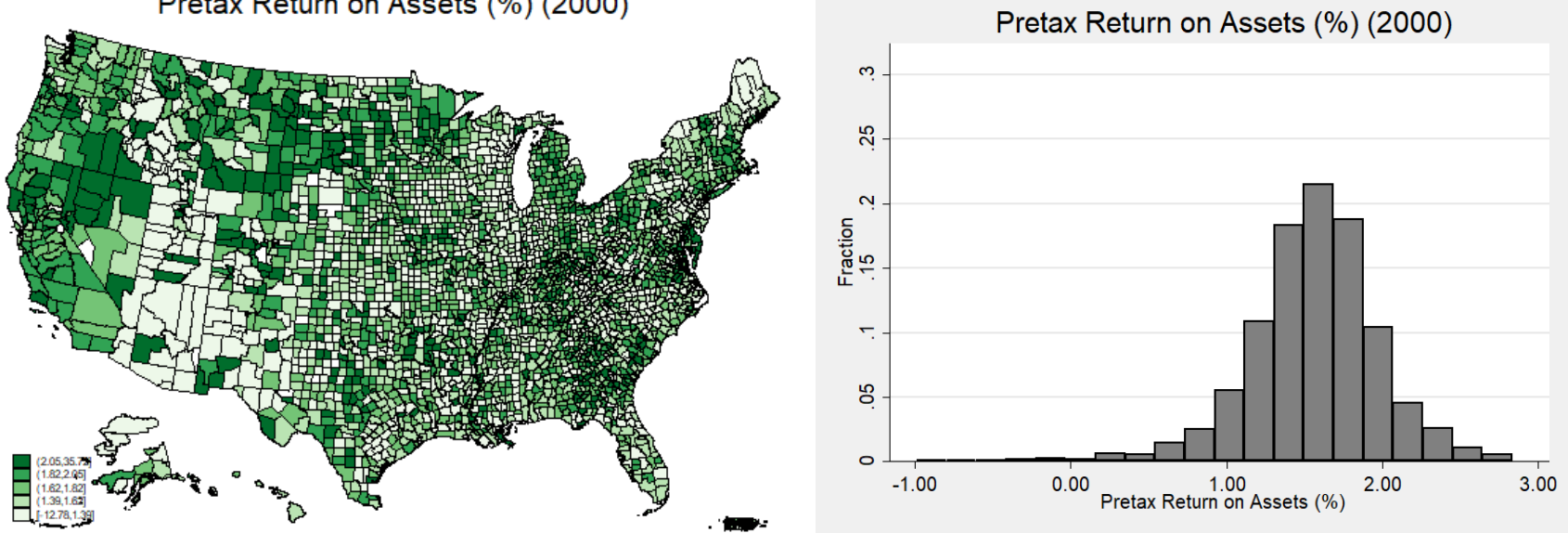

Pretax Return on Assets (\%) (2010)

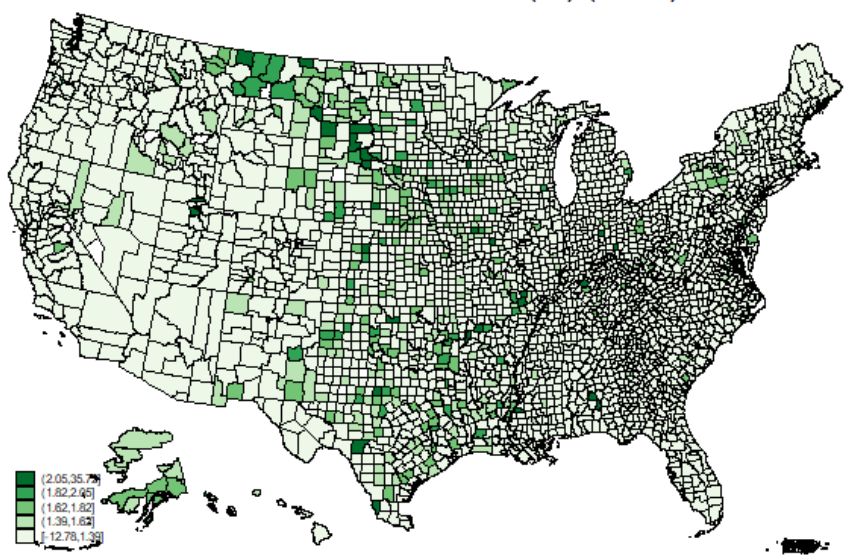

Pretax Return on Assets (\%) (2010)

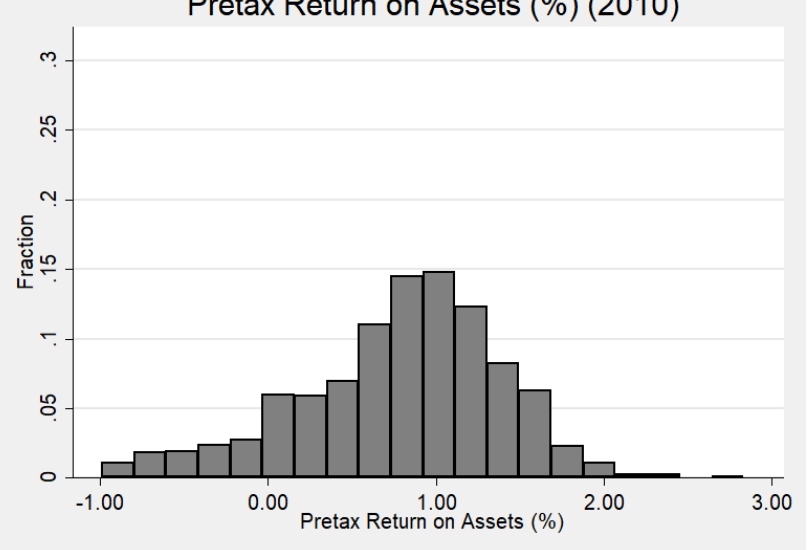

Pretax Return on Assets (\%) (2019)
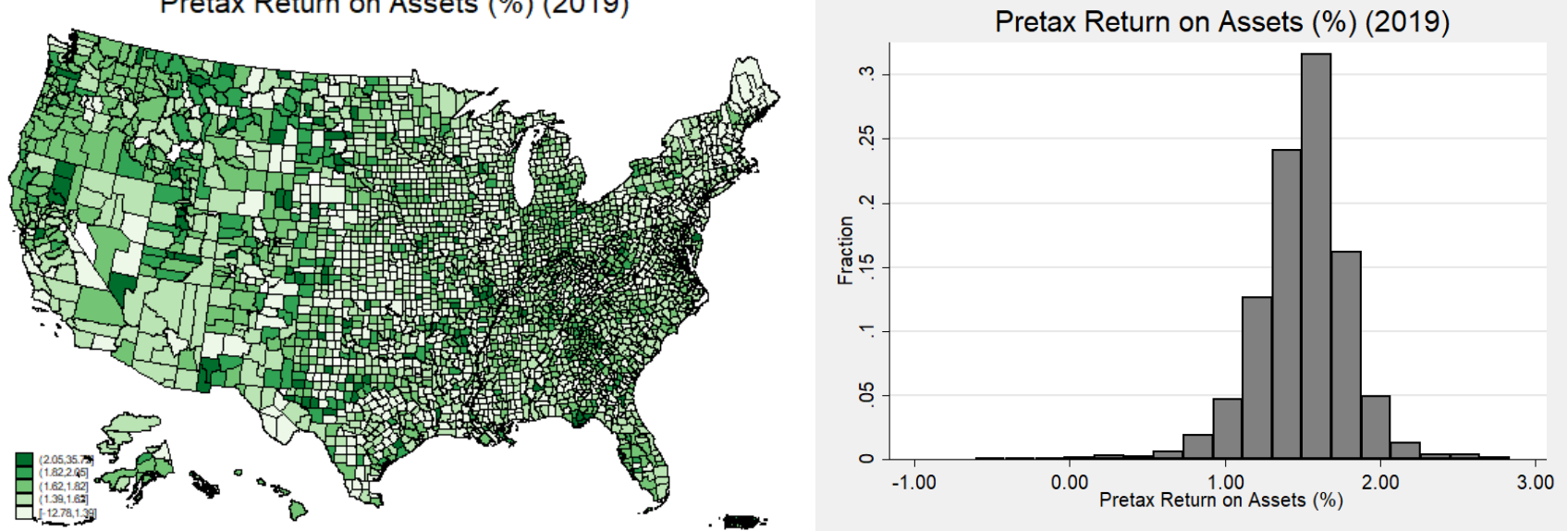

Note: This figure illustrates the average pretax return on assets across banks in each county and its distribution in 1990, 2000, 2010 and 2019. Brackets for the maps are based on quintiles in the year 2005. A darker area represents larger pretax return in one particular county. The histogram represents the fraction of counties that fall into the range of one bar (width is equal to $0.19 \%$, starting at value $-0.99 \%$ ). Outliers ( $<1 \%$-percentile or $>99 \%$-percentile using all data points) are excluded for the histograms. Please see the Online Appendix for a dynamic representation of the maps and histograms for all years. 

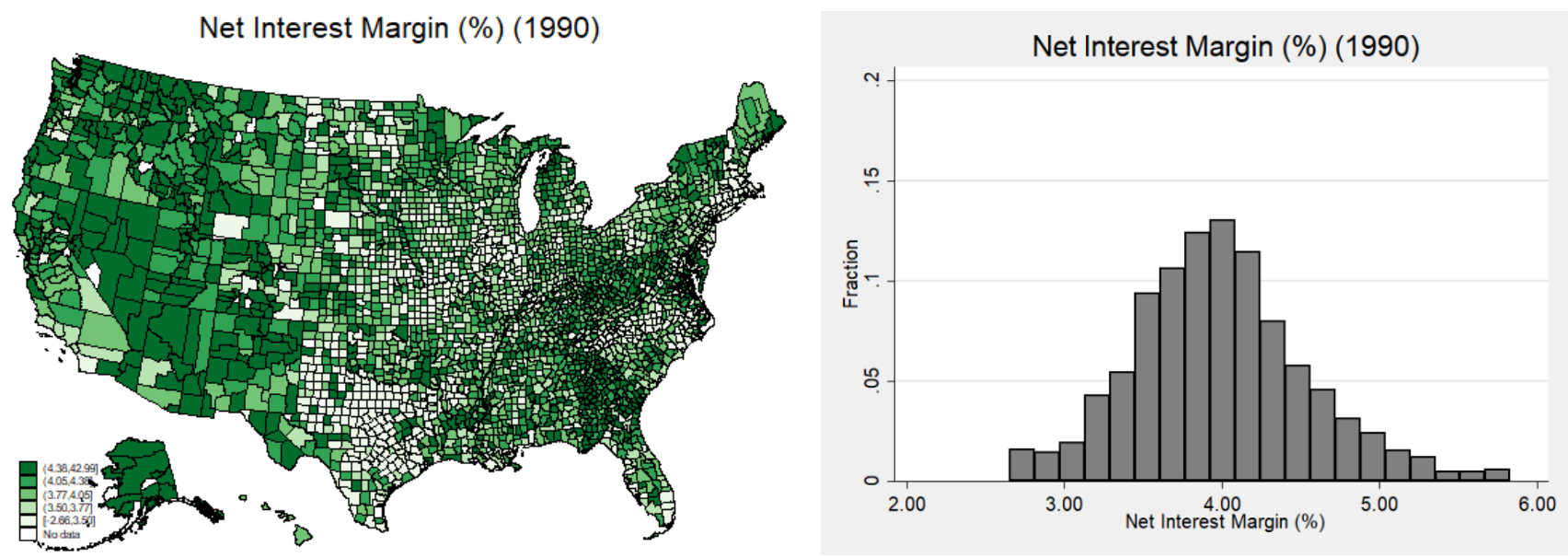

Net Interest Margin (\%) (2000)

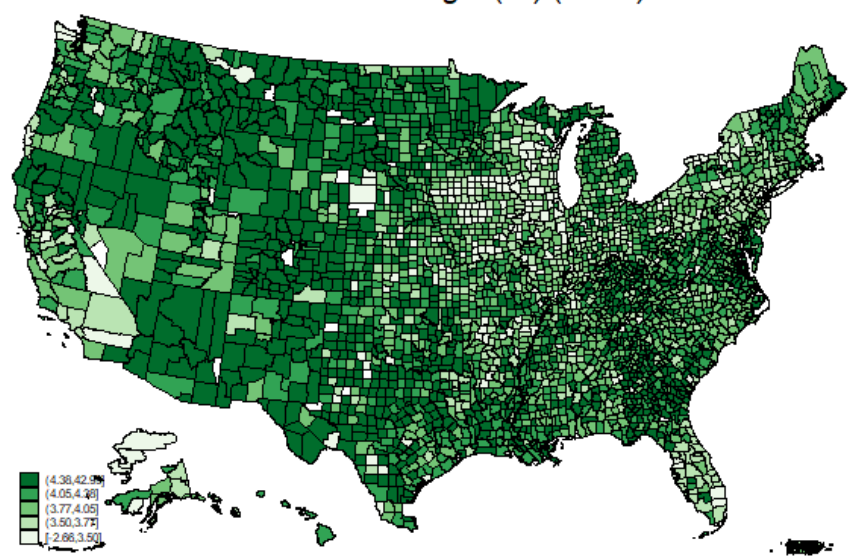

Net Interest Margin (\%) (2000)

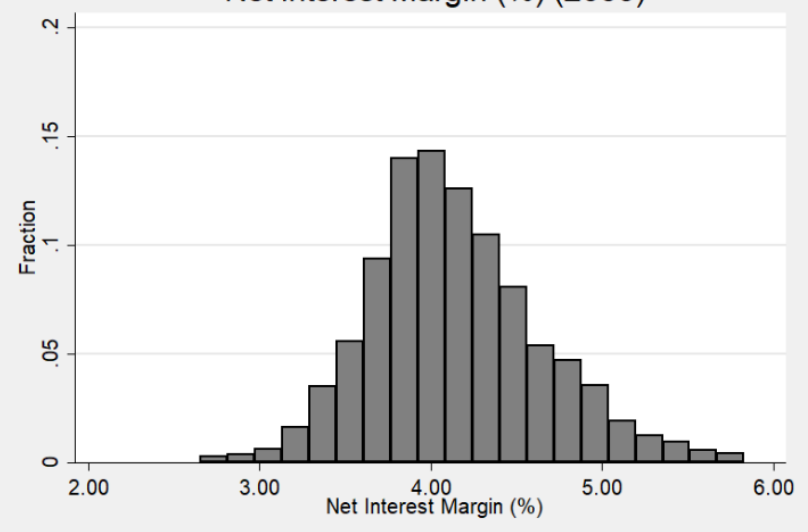

Net Interest Margin (\%) (2010)

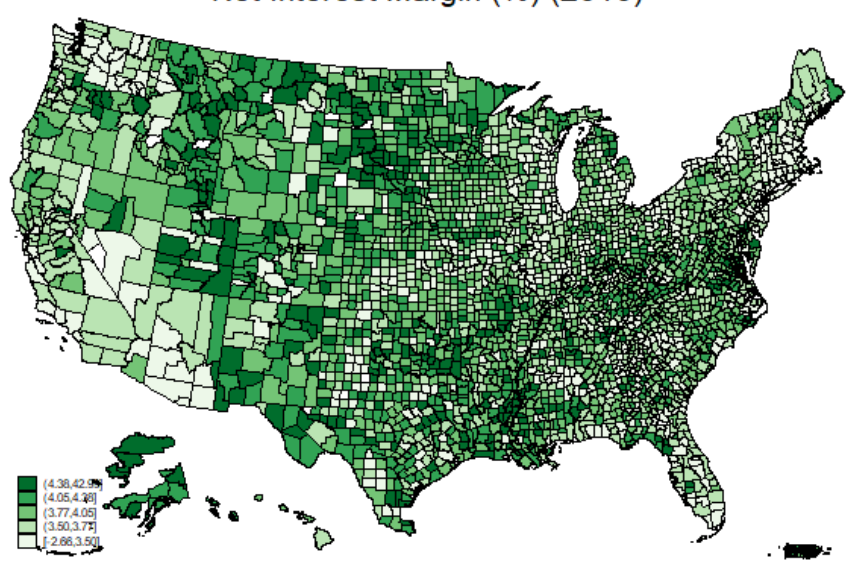

Net Interest Margin (\%) (2010)

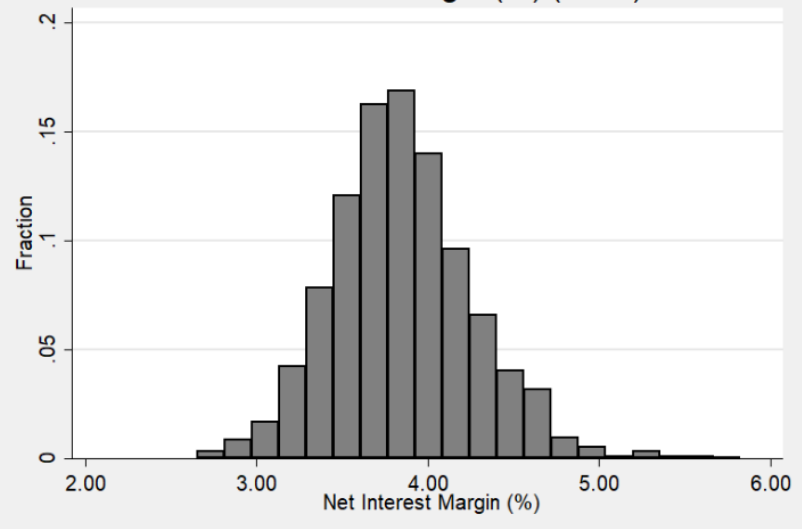

Net Interest Margin (\%) (2019)

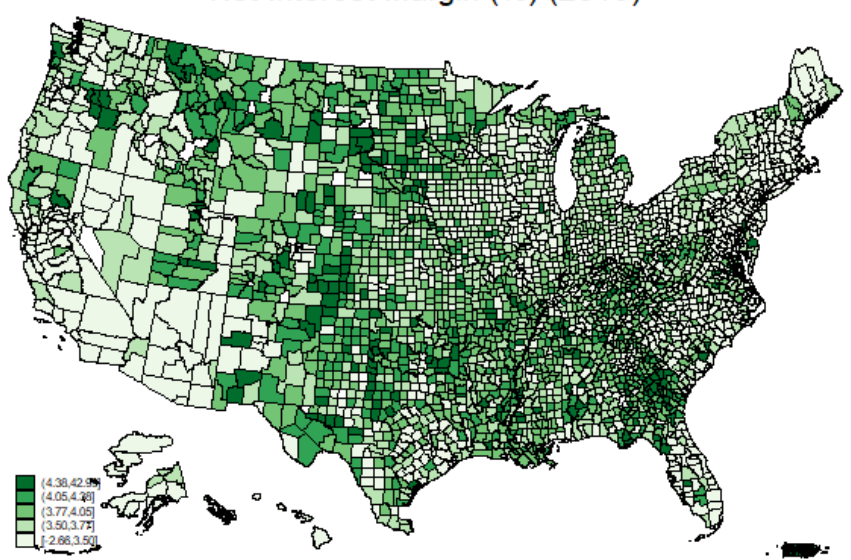

Net Interest Margin (\%) (2019)

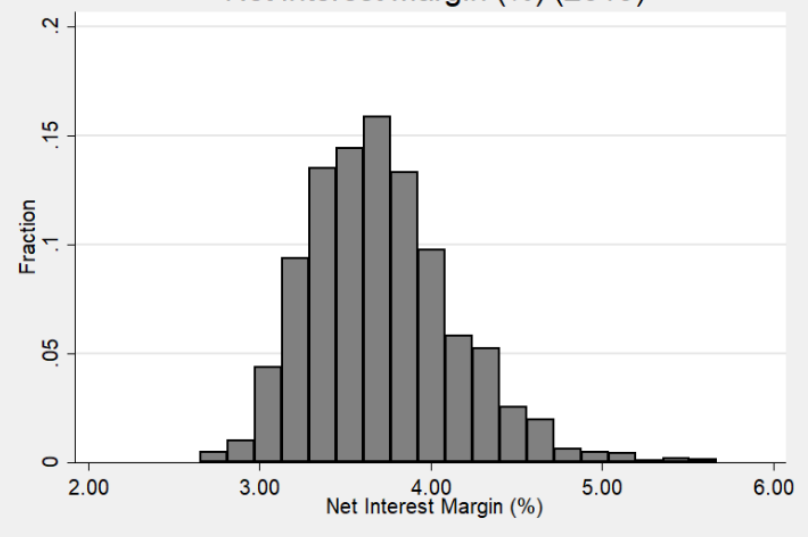

Note: This figure illustrates the average net interest margin across banks in each county and its distribution in 1990, 2000,2010 and 2019. Brackets for the maps are based on quintiles in the year 2005. A darker area represents larger margin in one particular county. The histogram represents the fraction of counties that fall into the range of one bar (width is equal to $0.16 \%$, starting at value $2.66 \%$ ). Outliers ( $<1 \%$ percentile or $>99 \%$-percentile using all data points) are excluded for the histograms. Please see the Online Appendix for a dynamic representation of the maps and histograms for all years. 
Figure C20: Non-performing assets ratio (\%)
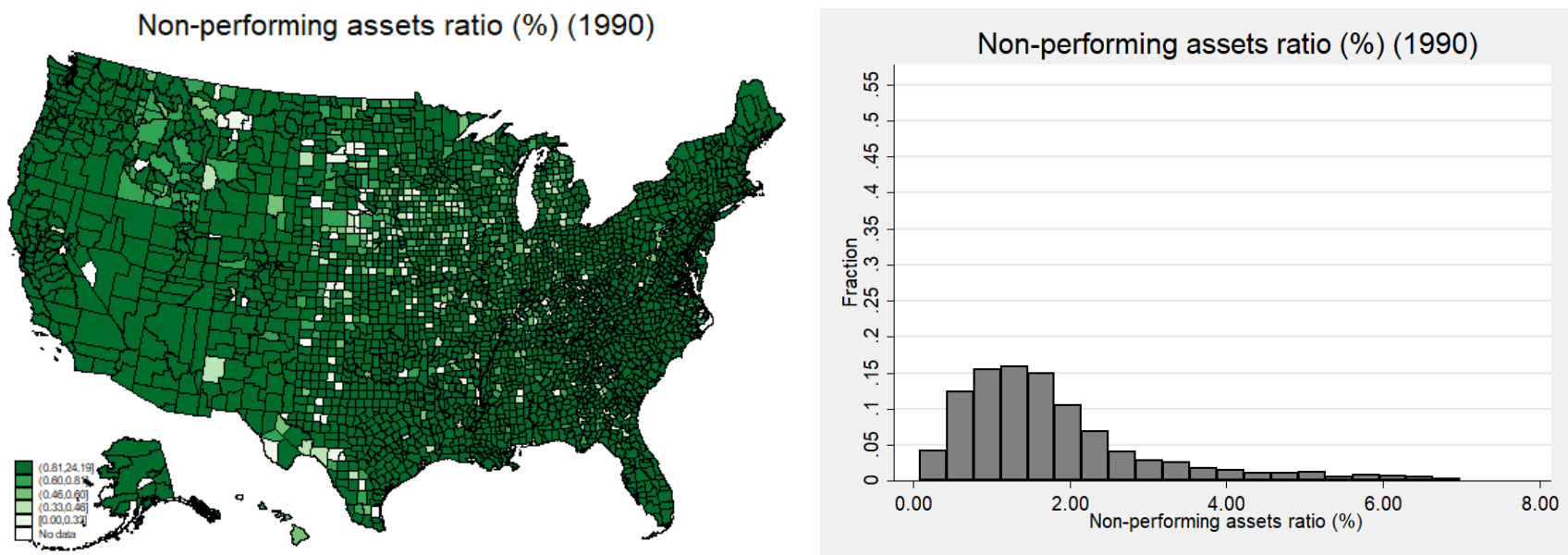

Non-performing assets ratio (\%) (2000)

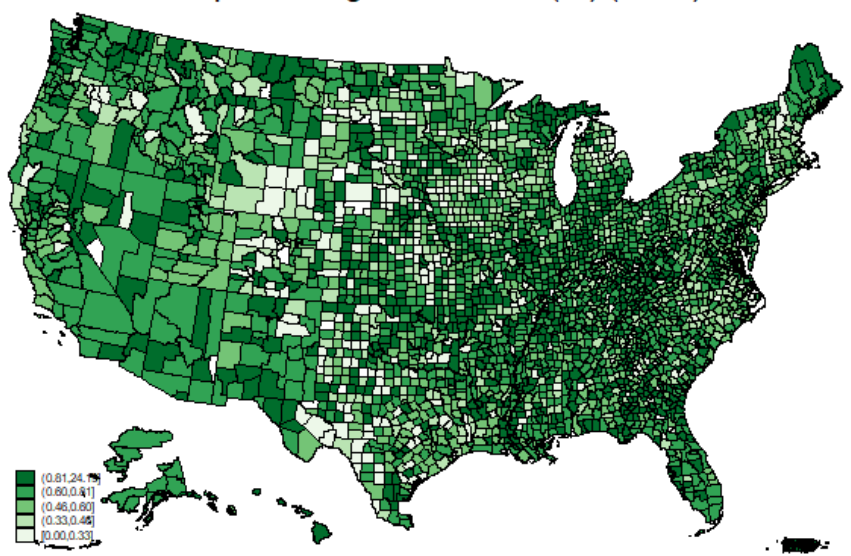

Non-performing assets ratio (\%) (2000)

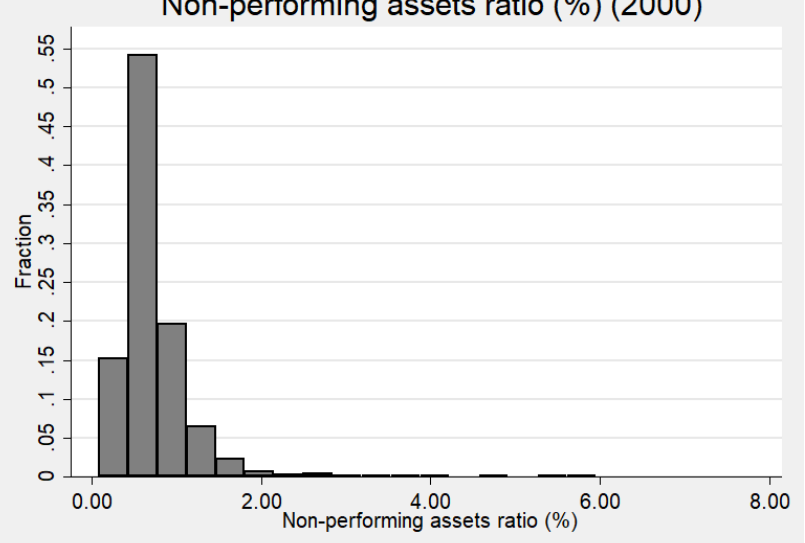

Non-performing assets ratio (\%) (2010)

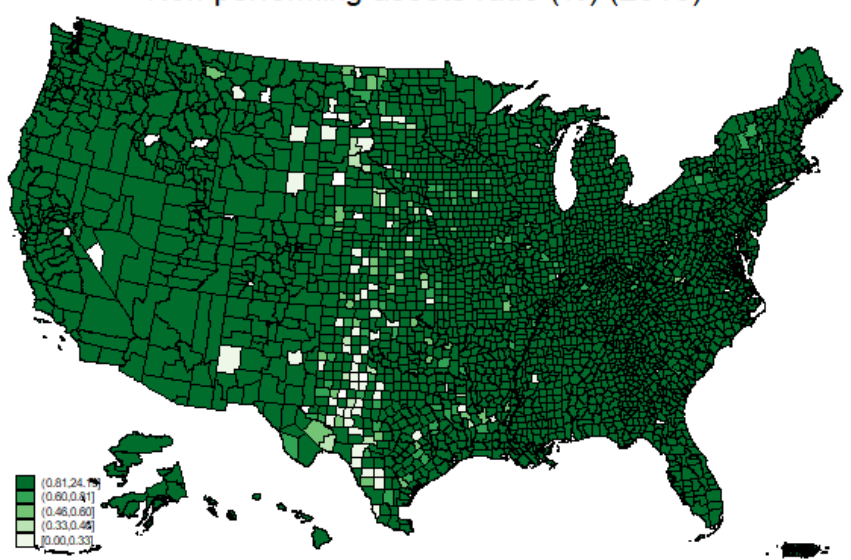

Non-performing assets ratio (\%) (2010)

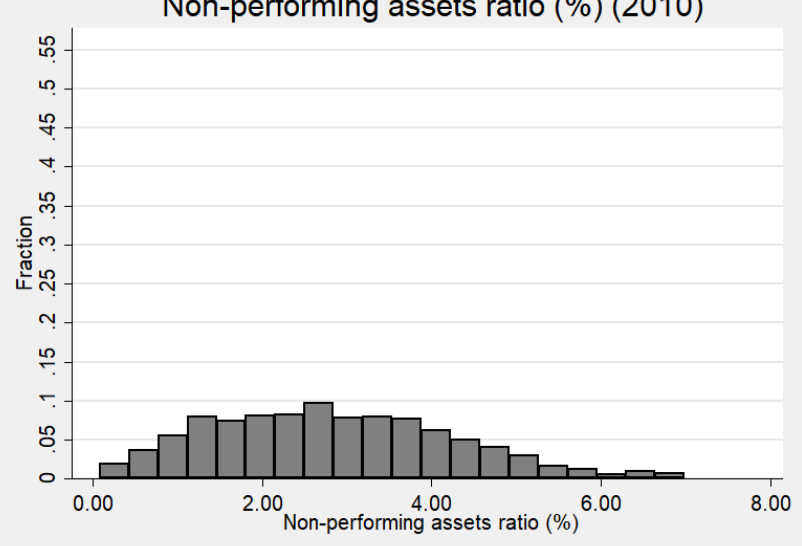

Non-performing assets ratio (\%) (2019)

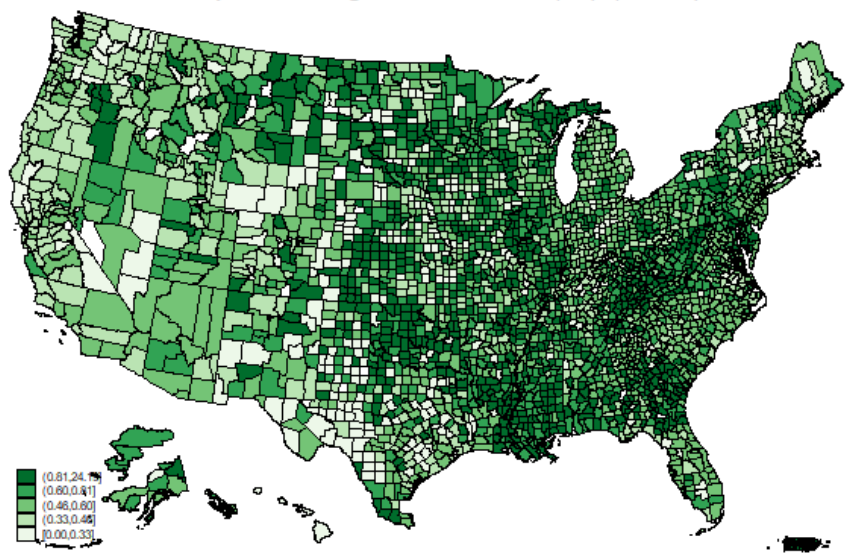

Non-performing assets ratio (\%) (2019)

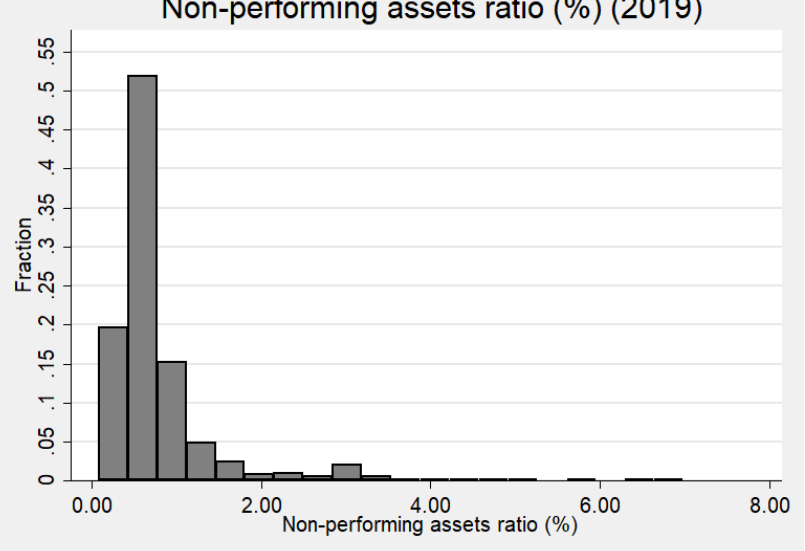

Note: This figure illustrates the average non-performing assets ratio across banks in each county and its distribution in 1990, 2000, 2010 and 2019. Brackets for the maps are based on quintiles in the year 2005. A darker area represents larger ratio in one particular county. The histogram represents the fraction of counties that fall into the range of one bar (width is equal to $0.35 \%$, starting at value $0.08 \%$ ). Outliers ( $<1 \%$-percentile or $>99 \%$-percentile using all data points) are excluded for the histograms. Please see the Online Appendix for a dynamic representation of the maps and histograms for all years. 


\section{Annex 4 - Example of potential disaggregation bias}

If deposit/asset ratios differ across banks, the distribution of deposits leads to a biased estimate of the characteristics of the bank asset mix. Intuitively, banks with a low deposit/asset ratio are underrepresented in the counties where they operate.

For example, suppose for simplicity there are two banks (1 and 2) operating in two counties (A and B). The data are as follows:

\begin{tabular}{|l|l|l|l|}
\hline Bank & County & Deposit & Total bank asset \\
\hline 1 & A & 100 & 500 (total assets of 1 held in both A and B) \\
\hline 1 & B & 100 & 500 (total assets of 1 held in both A and B) \\
\hline 2 & A & 200 & 600 (total assets of 2 held in both A and B) \\
\hline 2 & B & 400 & 600 (total assets of 2 held in both A and B) \\
\hline
\end{tabular}

Let $D$ be the matrix whose cell $D_{i j}$ contains share of deposits of bank $j$ collected in county $i$. The rows of $A$ contain the deposit shares in the given county, and sum to one. In our example,

$$
D=\left[\begin{array}{ll}
\frac{1}{3} & \frac{2}{3} \\
\frac{1}{5} & \frac{4}{5}
\end{array}\right]
$$

Let $A$ be the corresponding matrix, calculated using the estimated assets obtained by solving equations (1) to (4). In our example,

$$
A=\left[\begin{array}{ll}
\frac{250}{450} & \frac{200}{450} \\
\frac{250}{650} & \frac{400}{650}
\end{array}\right]=\left[\begin{array}{cc}
\frac{5}{9} & \frac{4}{9} \\
\frac{5}{13} & \frac{8}{13}
\end{array}\right]
$$

Comparing the two matrices one sees that bank 2 receives a larger weight in $D$ relatively to $A$, because its deposit ratio is higher. This introduces a bias in the estimate of county-level characteristics which depend on asset size. Suppose for example that bank 1 has a ratio of non-performing assets equal to $4 \%$, while bank 2 has a ratio of non-performing assets equal to 10\%, both distributed uniformly across the two regions. Using $D$, one obtains the following estimates of average county-level non-performing asset ratios: County A: $14.67 \%$, County B: $16.8 \%$. Using A, one obtains the correct values: County A: $11.11 \%$; County B: $13.85 \%$. 


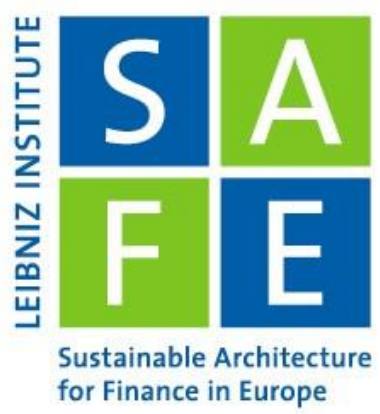

\section{Recent Issues}

No. 320 Sebastian Steuer, Tobias H. Tröger

No. 319 Erik Theissen, Christian Westheide

No. 318 Kevin Bauer, Michael Kosfeld, Ferdinand von Siemens

No. 317 Volker Flögel, Christian Schlag, Claudia Zunft

No. 316 Christian Mücke, Loriana Pelizzon, Vincenzo Pezone, Anjan Thako

No. 315 Kevin Bauer, Moritz von Zahn, Oliver Hinz

No. 314 Farshid Abdi, Mila Getmansky Sherman, Emily Kormanyos, Loriana Pelizzon, Zorka Simon

No. 313 Kevin Bauer, Andrej Gill

No. 312 Can Gao lan Martin

No. 311 Wenhui Li, Christian Wilde

No. 310 Carmelo Latino, Loriana Pelizzon, Aleksandra Rzeźnik

No. 309 Tabea Bucher-Koenen, Andreas Hackethal, Johannes Koenen, Christine Laudenbach

No. 308 Thomas Pauls

No. 307 Ester Faia, Andreas Fuster, Vincenzo Pezone, Basit Zafar
The Role of Disclosure in Green Finance

Call of Duty: Designated Market Maker Participation in Call Auctions

Incentives, Self-Selection, and Coordination of Motivated Agents for the Production of Social Goods

Momentum-Managed Equity Factors

The Carrot and the Stick: Bank Bailouts and the Disciplining Role of Board Appointments

Expl(Al)ned: The Impact of Explainable Artificial Intelligence on Cognitive Processes

A Modern Take on Market Efficiency: The Impact of Trump's Tweets on Financial Markets

Mirror, Mirror on the Wall:

Machine Predictions and Self-Fulfilling Prophecies

Volatility, Valuation Ratios, and Bubbles: An Empirical Measure of Market Sentiment

Separating the Effects of Beliefs and Attitudes on Pricing under Ambiguity

The Power of ESG Ratings on Stock Markets

Gender Differences in Financial Advice

The Impact of Temporal Framing on the Marginal Propensity to Consume

Biases in Information Selection and Processing: Survey Evidence from the Pandemic 